Historic, Archive Document

Do not assume content reflects current scientific knowledge, policies, or practices. 



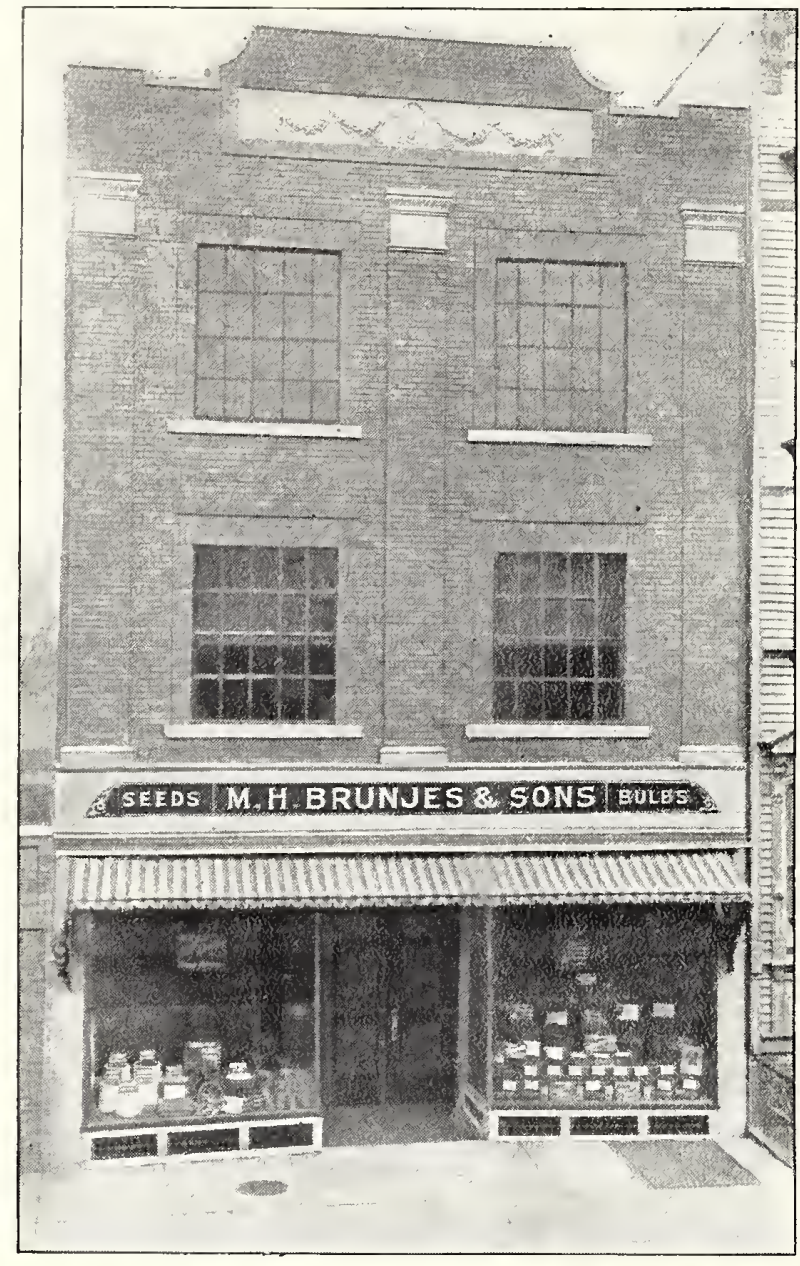

\section{Our 50th Anniversary}

Dear Reader:

Fifty years ago, in a small store at 1581 Myrtle Avenue, just a half block from our present location, Mr. Martin H. Brunjes started the seed business now known as M. H. Brunjes \& Sons. At that time we were in the midst of a farming district and our business was Iargely with market-gardeners. However, in later years land nearby became too valuable for farming, and we were soon in the heart of a growing city.

It has always been our aim to secure only the best seeds obtainable, regardless of price, and it is due to this policy that we have so many satisfied customers today and were able to crect the modern building at 1581 Gates Avenue.

To our customers who have by their patronage helped to develop our business, and thereby contributed to our success, we are very gratcful.

Trusting you will favor us with your valued orders, which will have our personal and most careful attention, we are

$$
\begin{aligned}
& \text { Yours very truly, } \\
& \text { M. H. BRUNJES \& SONS } \\
& \text { Bvenue } \\
& \text { Brooklyn, N. Y. }
\end{aligned}
$$

1581 Gates Avenue

\section{Read Carefully Before Ordering}

HOW TO ORDER. We advise placing your order early. Please use order sheets found in the baek part of the catalogue, earefully filling out blank spaces at top for shipping directions.

SEND CASH WITH THE ORDER. This ean be done either in the form of a Money Order, Bank Draft, Express Order or Registered Letter. Remittances sent in any other way are entirely at the sender's risk. Small amounts may be sent in postage stamps.

EXPRESS AND FREIGHT ORDERS. When orders are received to be shipped by express or freight, the purehaser must pay the charges.

\section{REGARDING PARGEL POST}

Within the United States and Possessions-Alaska, Canal Zone, Guam, Hawaii, Porto Rieo, and the Philippines.

THE MAXIMUM WEIGHT allowable is 70 pounds to all zones.
THE SIZE OF PARCEL must not exceed 100 inches for eombined length and largest girth.

SEEDS BY PARCEL POST. Orders for packets, ounces, and quarter-pounds will be sent by pareel post, postage free, at prices given. If larger quantities are wanted, add postage at your zone rate.

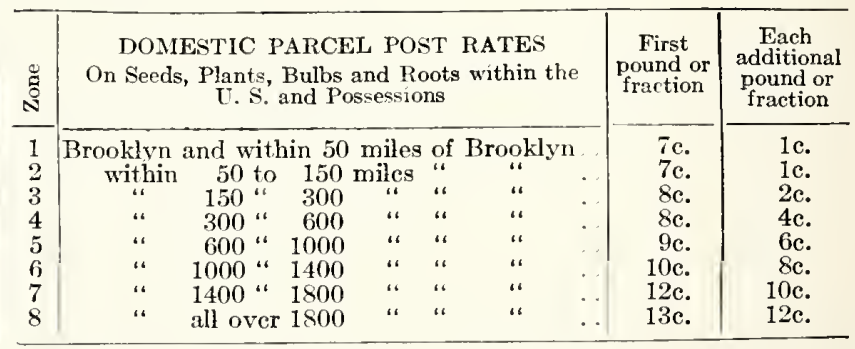

NON-WARRANTY M. H. Brunjes \& Sons give no warranty, express or implied, as to description, quality, proNON - WARRANTY. ductiveness, or any other matter of any seeds, bulbs, or plants they send out, and they will not be in any way responsible for the crop. If the purchaser does not accept the goods on these terms, they are at once to be returned. - M. H. B. \& Sons. 


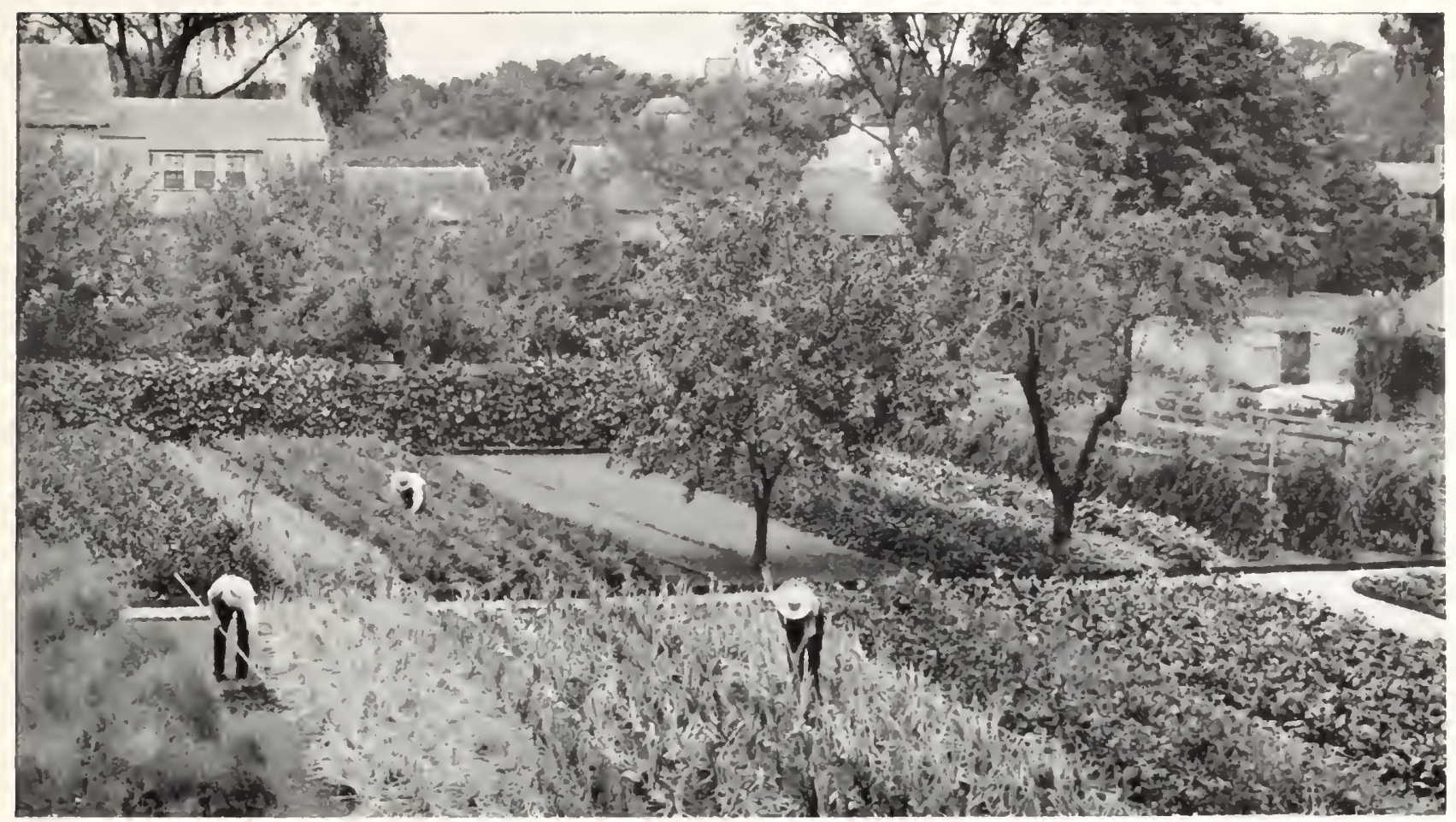

\section{H. BRUN.JES \& SONS' \\ Reliable Vegetable Seeds}

\section{Artichoke $\begin{gathered}\text { One ounce will pro- } \\ \text { duce } 500 \text { plants }\end{gathered}$}

To secure globes the first year sow the seed in hotbeds during Feloruary, and in May transplant in rows threc fect apart and two feet apart in the row, selecting a bed of deep, rich and rather moist soil. Seed may also be sown outdoors in .Iay, hut will not mature until the second year. In winter protect the erowns with a covcring of leaves or straw.

Large Globe. Heads light green, thick and fleshy. Per pkt. 10 cts., 0z. \$1.25.

Jerusalem. Unlike the above, the roots when pickled are the edable portion of this variety. but it is mainly grown for feeding stoek. Plant the tubers in rows four feet apart and

one foot apart in the row, cultivating same as potatoes. Five bushels will plant one acre.

Large tubers, per qt. 25 cts., pk. $\$ 1.25$, bush. $\$ 4$.

\section{Asparagus}

One ounce will sow about 50 feet of drill; 1 pound will produce enough plants for 1 acre

Sow the seed outdoors about April or May in drills one foot apart and two inches deep. When well developed, plants should be thinned out to two inches apart and the following spring, or preferably when two years old, transplanted to permanest beds of sandy soil that has been thoroughly dug and well enriched with manure. Set plants twelve inches apart in trenches eighteen inches wide and after earefully spreading the roots cover to depth of four inches; and the second row three or four feet from the first. Cultivate frequently and add a top dressing of well-rotted manure or wood-ashes in the fall. Cutting should not take place until roots are four ycars old.

Palmetto. An early sort with light green shoots of the finest quality. Pkt. 5 cts., oz. $10 \mathrm{cts.}$., $\frac{1}{4} \mathrm{lb}, 30 \mathrm{cts}, \mathrm{lb} .90 \mathrm{cts}$.

\section{ISPARAGIS ROOTS}

\section{$A$ bed twelve by thirty-two feet requires 100 roots}

Results are obtained two years earlier by planting roots.

Giant Washington. (Pedigreed stock.) The best Asparagus, whether for the market or home garden. It is early, very productive, rust-resisting, and the large, tender, deep green
shoots are of the most delicious flavor. Strong, two-ycar-old roots, $75 \mathrm{cts}$, for $25,32.75$ per $100, \$ 25$ per 1,000 .

Palmetto. Strong two-year-old roots. $50 \mathrm{cts}$, for $25, \$ 1.75$ per $100, \$ 15$ per 1,000 .

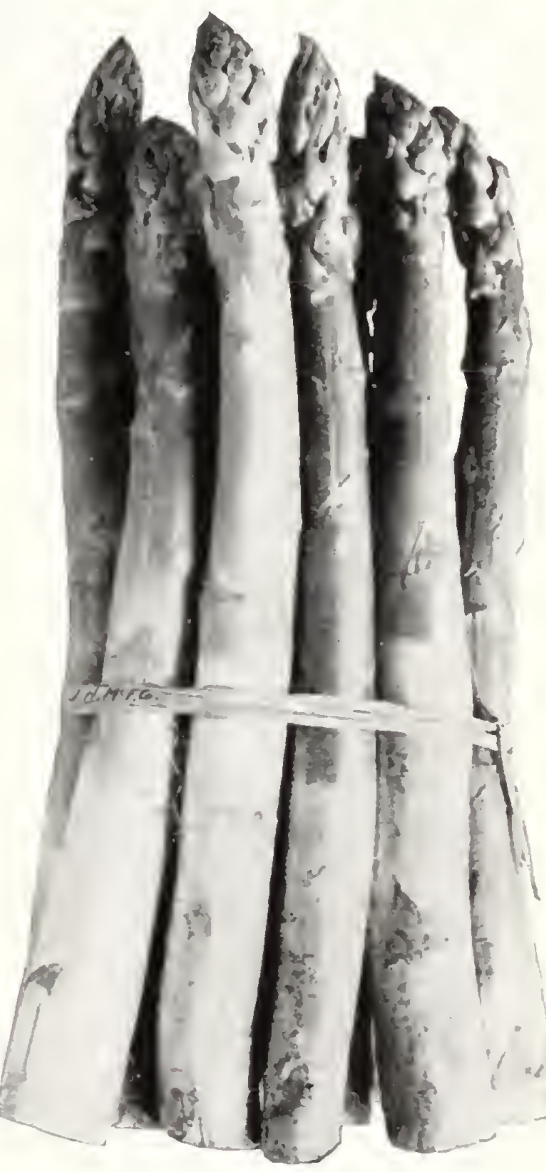

Asparagus, $\mathrm{Palmetto}$ 


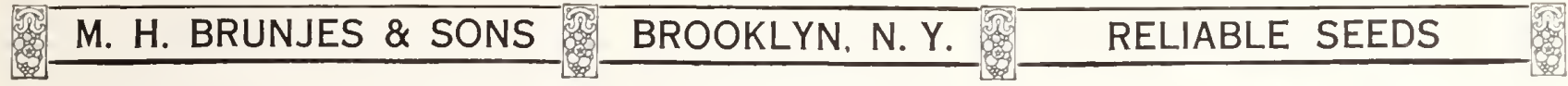

\section{BEANS, BUSH, WAX-PODDEI)}

IF BY PARCEL POST, ADD POSTAGE AT ZONE RATE

New Kidney Wax. An attractive Wax Bean resembling Wardwell's Kidney Wax but

broad; brit tle, stringles

Davis White Kidney Wax.

$2 \mathrm{lbs}$. $5.5 \mathrm{cts}$. $10 \mathrm{lbs} .82 .50$.

Hodson Wax. In growth of vine and productiveness this variety exceeds

any other Wax-podded Bean. The long, flat pods, slightly curved, are

of handsome appearance and usually
lb. 30 ets., 2 lbs. 5 .
cts., $10 \mathrm{lbs} . \$ 2.50$.

Improved Golden Wax. Simall plants of ereet growth, bearing

of excellent quality. An early and reliable variety recommended

for hone use. $\frac{1}{2} \mathrm{lb} .15$ ets., $1 \mathrm{~b} .30$ cts., 2 lbs. 55 cts., $10 \mathrm{lbs.} \$ 2.50$.

Pencil-Pod Black Wax. of a beautiful yellow; medium early and equal to the best in quality. Mlb. 15 ctts., lb. 30 ct t3., 2 lbs. 55 cts., 10 lbs, $\$ 2.50$.

Stringless Refugee Wax. Popular for either early or hate planting. Plants are large, spreading and heavy yicklers of round, fleshy-

Sure-Crop Stringless Wax.

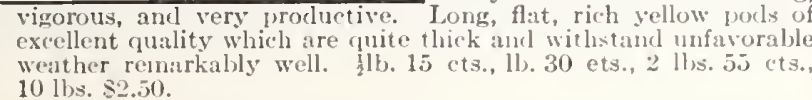

Wardwell's Kidney Wax.

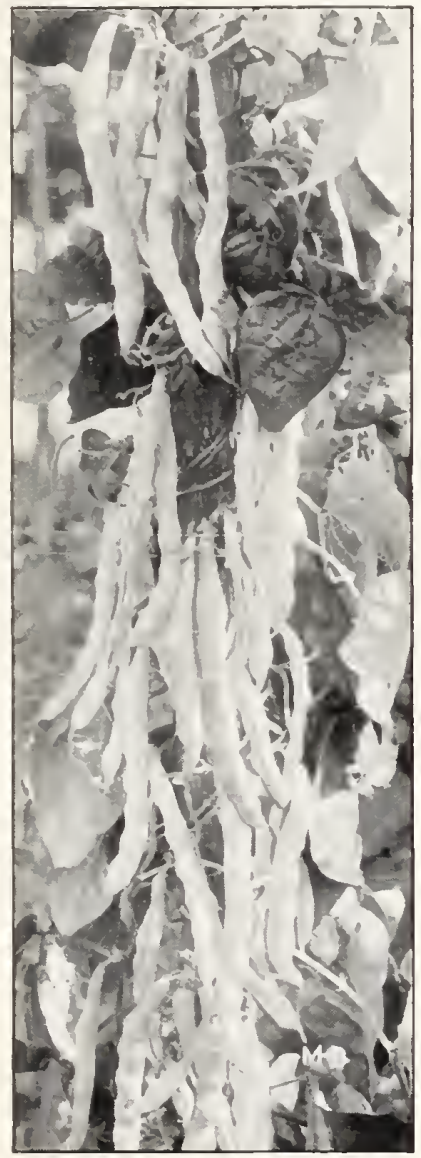

Bears, Old Homestead
TRY BANTAM EVERGREEN SUGAR CORN

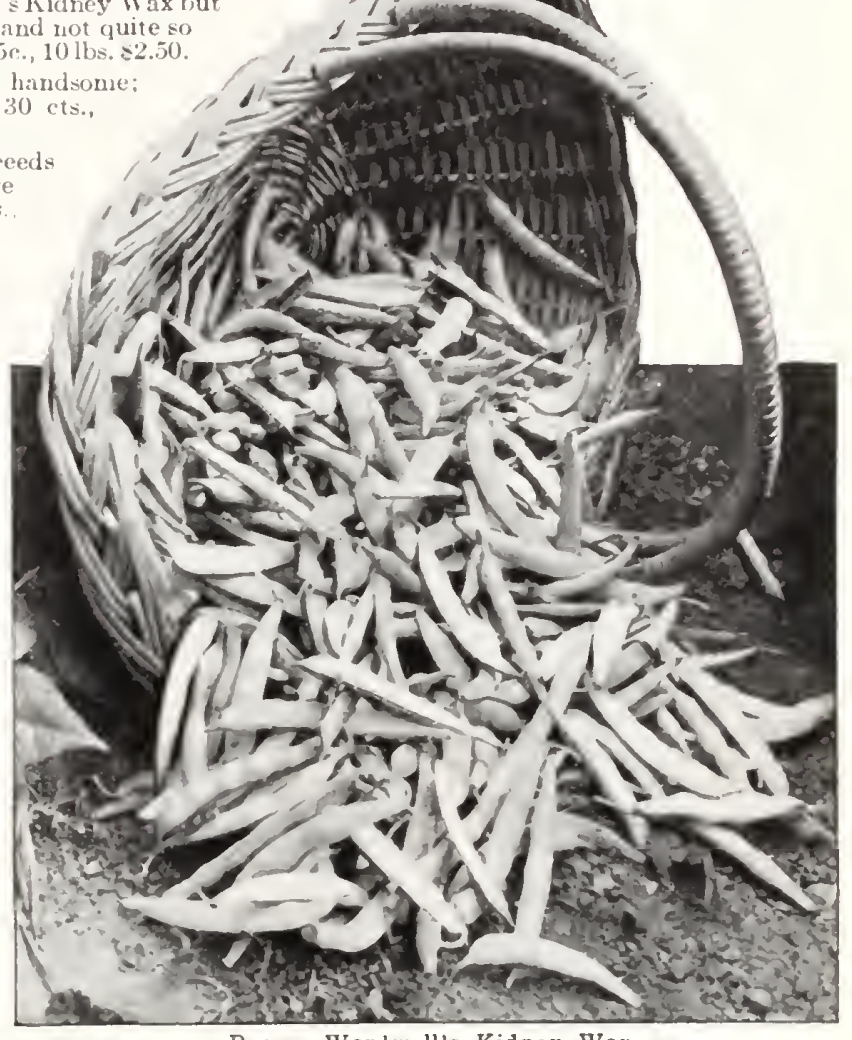

Beans, Wardwell's Kidney Wax

\section{GREFN-AND WAX-PODIEI)}

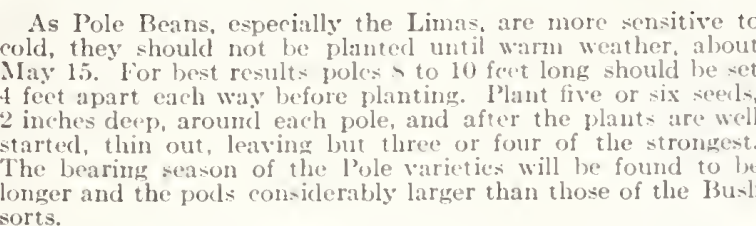

Kentucky Wonder Wax.

Old Homestead, or Kentucky Wonder.

This is decidedly the best of all (ireen-podcled Pole
Beans. The vines are of gool climbing labit and
heavy yielders of long, almost round porls, s to 10
inches in length, of the very best quality. An early and
well-recommended sort for the home-garden. ylb. 20 ets.,
lb. 35 cts., 2 lbs, 70 cts., $10 \mathrm{lbs}, 83.25$.

Scarlet Runner. Generally grown as an ornamental climber. with bright scarlet flowers, but the Beans may also be used in the green state. Excellent for corering porches, the 20 cts. etc., blooming from early summer unt il
lb. 35 ets., 2 lbs. 70 ets., $10 \mathrm{lbs}$. $\$ 3.25$.

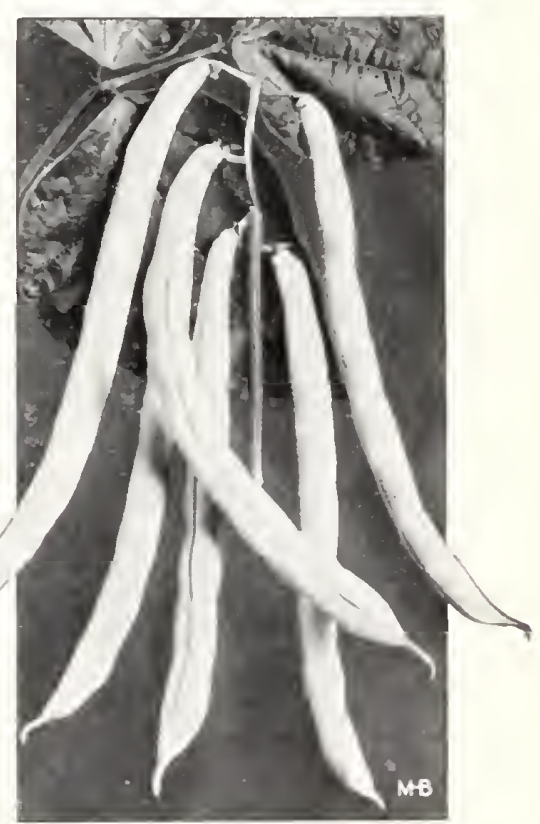

Beans, New Kidney Wax 


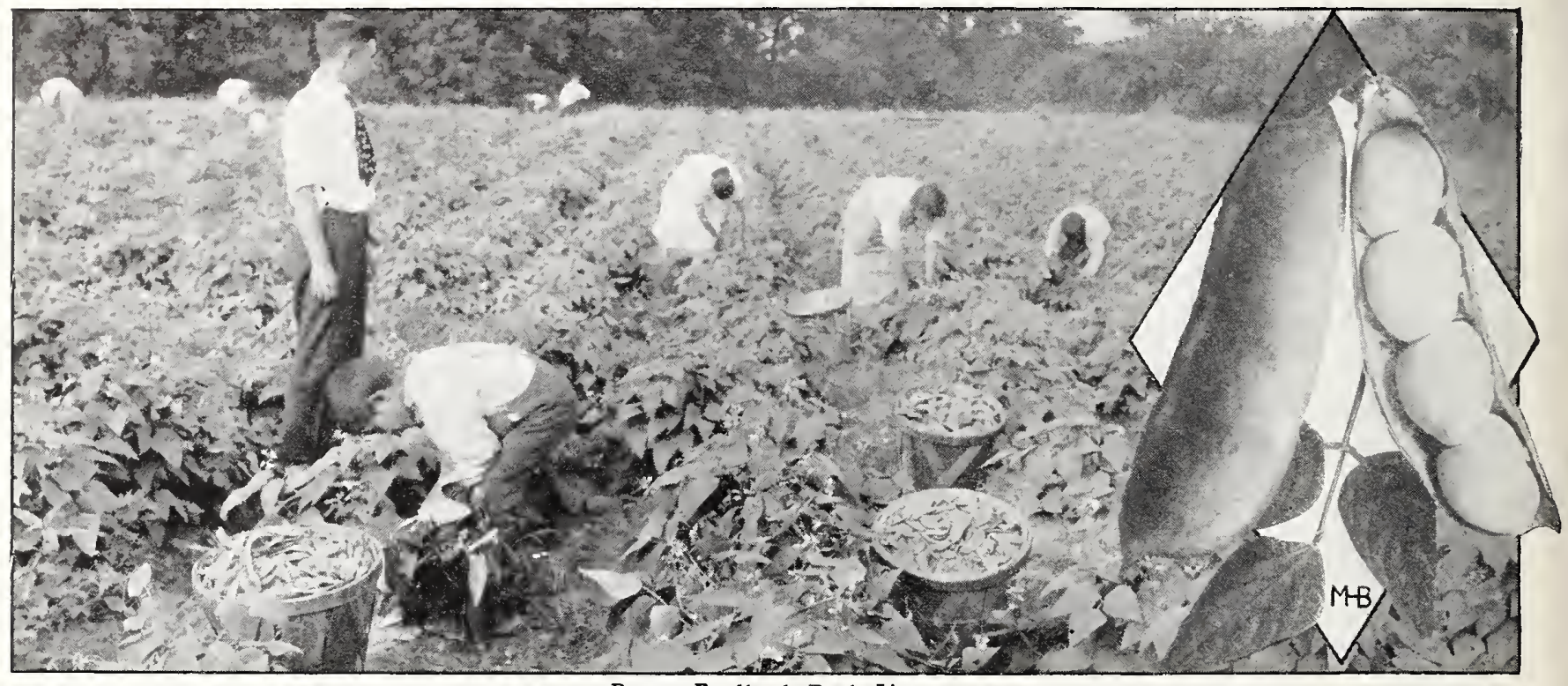

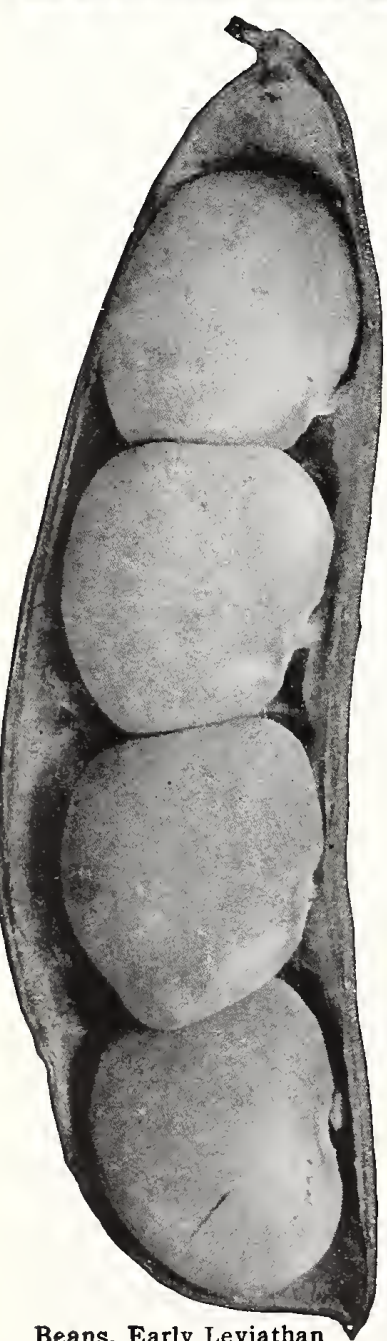

Beans, Early Leviathan Pole Lima

\section{Beans, Bush Lima}

IF BY PARCEL POST, ADD POSTAGE AT ZONE RATES:

Bush Limas are more sensitive to cold than the ordinary garden Bean and therefore should not be planted before the soil becomes warm and dry, usually about May 15. They also require a longer season to mature and should not be planted later than July 15. Plant in drills 2 feet apart and 10 inches apart in the row, about 2 inches deep.

Fordhook Bush Lima. The pods of this wonderful Bush Lima are not only double the size of the a. well-known Dreer's or Kumerle, but are thicker and produced in greater abunBurpee's Improved Bush Lima. This is the finest Bush Lima that has ever been introduced bons are of enormous size, containing from three to five twice as thick. In quality it is of the best. The bushes when fully grown measure $2 \frac{1}{2}$ feet in height and 24 inches across the top. It is about one week earlier than Burpee's Bush Lima. $\frac{1}{2} \mathrm{lb} .20$ cts., lb. 40 cts., 2 lbs. 75 cts., 10 lbs. $\$ 3.50$.

Burpee's Bush Lima. Plants vary from 18 to 24 inches in height, somewhat spreading and yielding long, flat pods, about 4 inches long, containing 3 or 4 beans of delicious flavor. $\frac{1}{2} \mathrm{lb} .20 \mathrm{cts}$., lb. 40 cts., 2 lbs. 75 cts., $10 \mathrm{lbs} \$ 3.50$.

\section{BEANS, ENGLISH or BROAD}

Broad Windsor A distinct variety that requires early planting, preferably the latter part of March or Broad Windsor. early in April, to obtain best results. The beans should be planted in rows 3 feet apart, dropping the seeds 6 inches apart in the row and 2 to 3 inches deep. Pods usually contain two or three beans. $\frac{1}{2}$ lb. 20 cts., lb. 40 cts., 2 lbs. 75 cts.

\section{Beans, Pole Lima}

One pound will plant 50 hills

For culture, see other Pole Beans

Early Leviathan. The earliest of all Pole Limas and therefore one of the most reliable, either for the beans, unarket or private garden. The long, straight pods contain from three to five large flavor, and are borne in large clusters sontinuously until fate in the season. $\frac{1}{2} \mathrm{lb} .20 \mathrm{cts}$. lb. 35 cts., 2 lbs. 65 cts., 10 lbs. $\$ 3$.

Ford's Mammoth-Podded. Where size of pod is the first consideration, this variety leads the list. Vines are unusually vigorous, enormously productive and of good climbing habit, while the pods, giant in size, are well filled with delicious beans. $\frac{1}{2} \mathrm{lb}$. 20 cts., lb. 35 cts., 2 lbs. 65 cts., 10 lhe, $\$ 3$.

Challenger Lima. This is today and always has been a favorite market sort thick-podded, a good yielder and matures early. $\frac{1}{2} \mathrm{lb} .20$ cts., lb. 35 cts., 2 lbs. 65 cts., 10 lbs. $\$ 3$.

Dreer's Improved Lima. A fine, early variety, very productive and of superior quality. Pods very thick, about 4 to 5 inches in length and generally contain about 4 to 5 seeds. $\frac{2}{2}$ lb. 20 cts., lb. 35 cts., 2 lbs. 65 cts.,
10 lbs. $\$ 3$.

\section{Kills Ants in Their Nests}

The Antrol system is adapted to any size house or garden, and quickly destroys all species of sweet-eating ants. It is composed of small glass containers partílly filled with syrup, and placed along ant "trails" in the garden. Antrol Sets containing 4 Containers and 14 -oz. bottle of Syrup, 95 cts. Not maslable.

\section{Quickly Kills Grarden Pests \\ Snarol is a ready-prepared meal that you simply broad- cast on the ground, under the vegetation. The pests eat the meal, and are quickly destroyed Snarol will not de- teriorate from rain or sprinkling, and also is non-injurious to vegetation when used according to simple directions. $11 / 2-1 \mathrm{~b}$. pkg. 45 cts. Not mailable.}




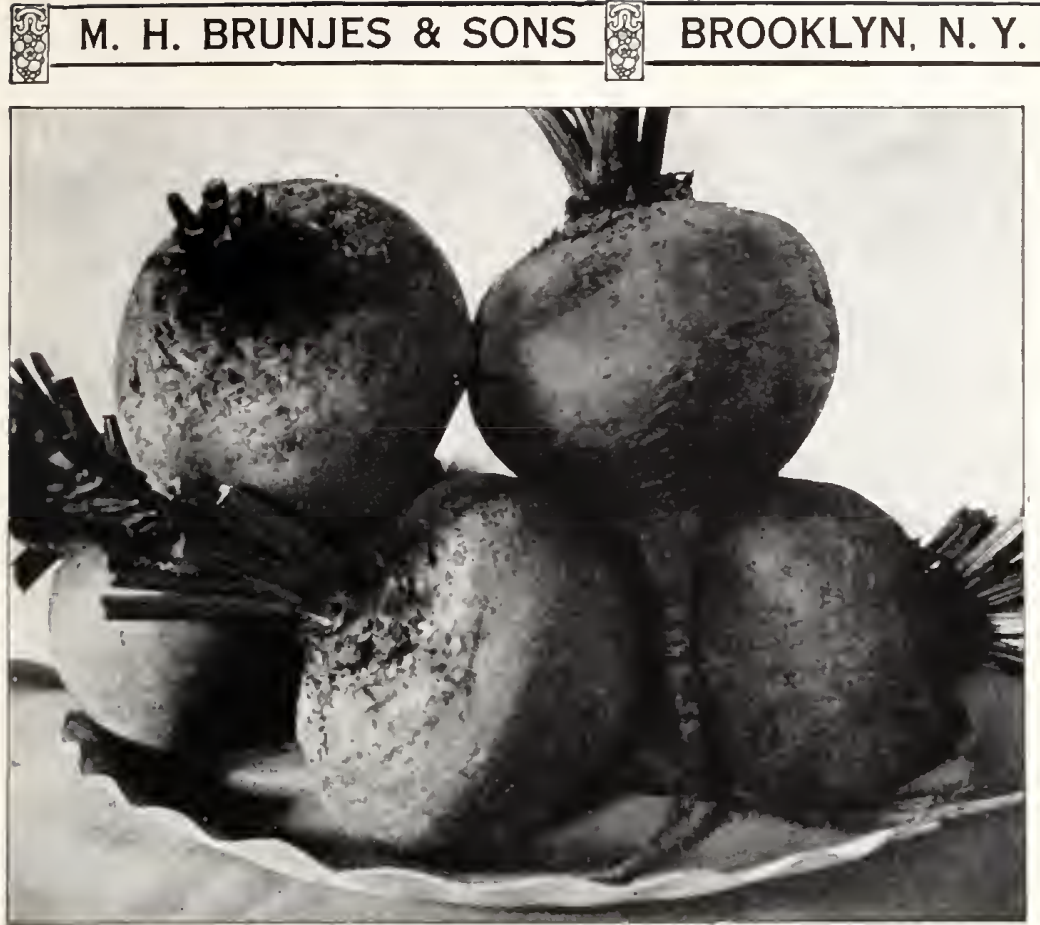

Beets, Edmand's Early Blood Turnip
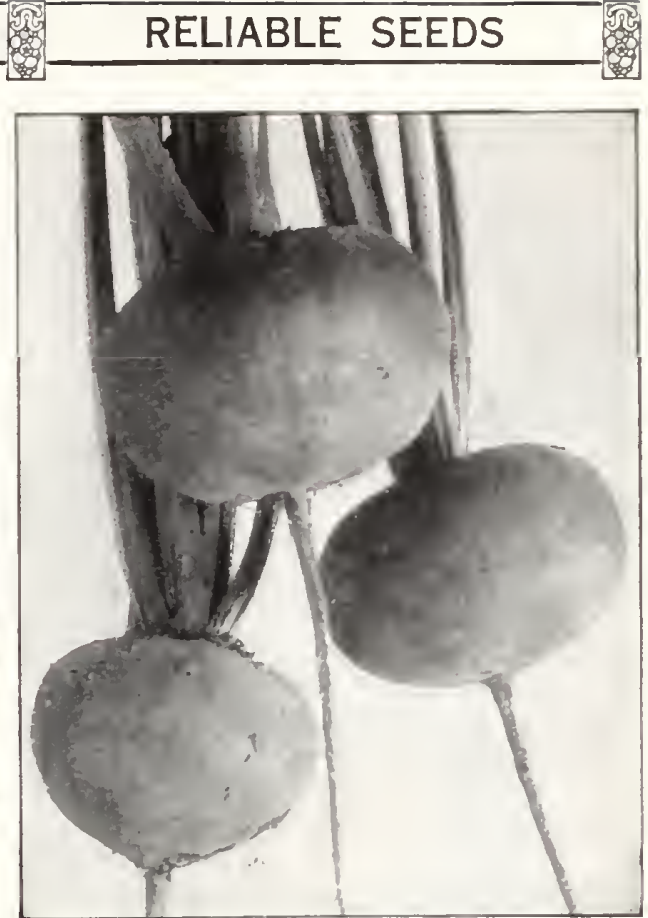

Beets, Crosby's Extra-Early Egyptian BEETS

One ounce will sow 50 feet of drill; 6 pounds for an acre

Best results are obtained by using a light soil that has been well emriehed with manure. Sow in drills 1 foot apart and 1 inch deep, as soon as the ground is in workable eondition, and for succession every two weeks until dugust. When the plants are well advaneed thin out to $t$ or 5 inches apart. A liberal sowing should alway's be made during July for a winter erop.

Crosby's Extra-Early Egyptian. An improved strain of the well-knowis and very popular Early Egrptian, and, like that what flattened; flesh bright vernilion-red and in quality unsurpassed for flavor and fine grain. Pkt. 5 ets., oz. 15 ets., ${ }_{1}^{1} 1 \mathrm{~h}$. 40 ets., $1 \mathrm{~b} . \$ 1.25$.

Crimson Globe. This is one of the finest Beets yet introduced. The roots are of medium size, and handsome appearanee, round, with a clean, smooth surface. Pkt. 5 ets., oz. 15 ets., $\frac{1}{1} 1 \mathrm{l}$. 40 cts., 1b. $\$ 1.25$.

Detroit Dark Red Turnip. This variety cannot be too highly recommended. It is not only one of the best fut is equally valuable for either early or late sowing. The root is globular in shape, very smooth, of a blood-red color and uniform size. Pkt. 5 cts., oz. 15 ets., $\frac{1}{b}$ b. 40 ets., lb. $\$ 1.25$.

Dewing's Early Blood Turnip. Owing to its large tops and fine keeping qualities this Beet is largely used for late sowing. The flesh of the dark red, turnip-shaped roots is of good eolor and fine quality. Pkt. 5 ets., oz. 15 ets., ${ }_{4}^{1} 1 \mathrm{~b} . \pm 0 \mathrm{ets}, 1 \mathrm{~b} .81 .25$.

Early Egyptian. A favorite for sowing early in the frames and for the Early Egyptian. first crop outdoors. It has small, deep green leaves, darkest eolor, very sweet and tender. Pkt. 5 cts., oz. 15 cts., $\frac{1}{4}$ lb. 40 cts., ll. 81.25

Early Model. An extremely early Beet of deep blood-red color, with rather short tops and rery smooth, globe-shaped roots. It is one of the sweetest and tenderest in our list and raluable both for the frames and outside sowing. Pkt. 5 ets., oz. 15 ets., 11 lb. 40 cts., 1b. $\$ 1.25$.

Early Wonder. A very fine selection of deep blood-red Beet partieularly recomsmall tops and mature so evenly that the entire erop may be harvested at on time. IIarket-gardeners will find Early. Wonder a raluable variety to sow as an early bunch Beet. Pkt. 5 ets., oz. 15 cts., $\frac{1}{4} 1 \mathrm{~b} .40$ ets., $16 . \$ 1.25$.

Edmand's Early Blood Turnip. A splendid Beet for late planting. The roots are of medium size, almost round but slightly flattened, of good color, with sweet, juicy flesh; exeellent keeper. Pkt. 5 ets., oz. 15 ets., $\frac{116}{4}$. 40 cts., 1b. $\$ 1.25$.

Improved Blood Turnip. A remarkably fine Beet for either early or the darkest color and highest quality. Pkt. 5 ets., oz, $15 \mathrm{cts}$. $1 \mathrm{lb} .40$ cts. lb. $\$ 1.25$.

Long Smooth Blood. An exeellent sort which keeps well during the winter. The roots, when fully matured, are almost a foot in length, half forming above the ground; very smooth, with few side roots. The skin and flesh are both of the darkest red color. Pkt. 5 ets., oz. 15 ets., $\frac{1}{4}$ b. 40 cts., lb. $\$ 1.25$.

Swiss Chard. For deseription and price, see page 25.

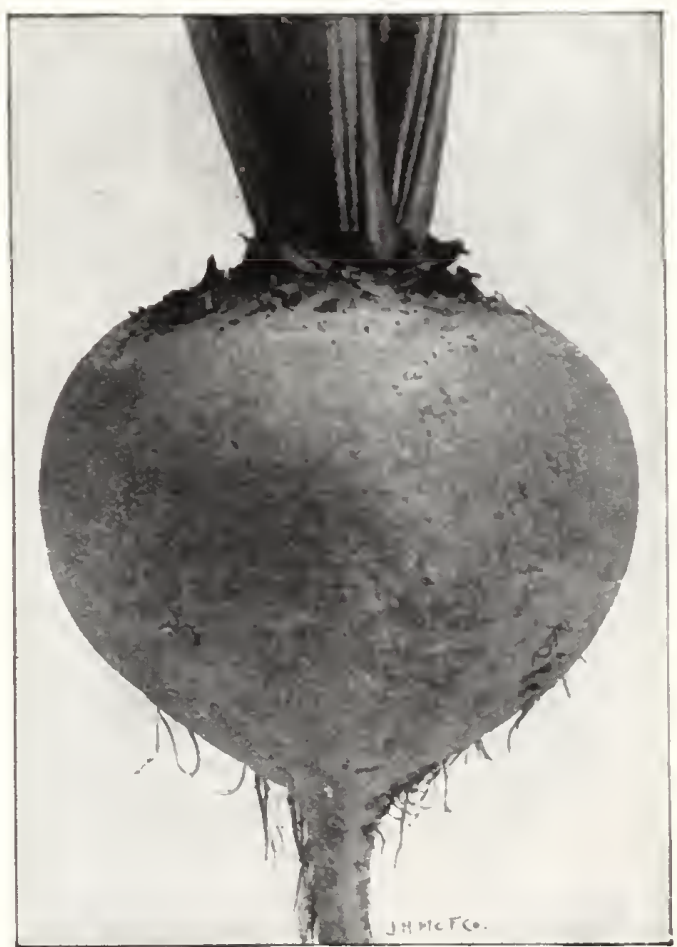

Beet, Dewing's Early Blood Turnip 


\section{MANGEL-WURZEL}

\section{Six pounds will sow an acre}

Mangel-Wurzels arc invaluable for fceding stock. In May or June sow the seed in drills not less than 2 feet apart and later thin out so the plants stand from 6 to 8 inches apart in the row. As they grow to an immense size, a deep soil that has been well euriched with stable manure is best suited for their culture.

Mammoth Long Red. A standard sort yielding long, thick, straight roots, having light red-colored flesh. It is prized for feeding stock during the winter and is undoubtedly the most largely grown of all Mangels. Oz. 10 cts., $\frac{1}{4} \mathrm{lb}$. $25 \mathrm{cts}$., $1 \mathrm{~b} .75 \mathrm{cts}$.

Yellow Globe. Large, globe-shaped; flesh white, tinged yellow. Suited to light or shallow soils. Oz. 10 ets., ilb. 25 cts., lb. 75 cts.

Golden Tankard. One of the best ycllow varieties, having small tops and smooth, oval-shaped roots. Flesh yellow zoned with white. Very productive and a good keeper. Oz. 10 cts., $\frac{1}{4}$ lb. 25 cts., lb. 75 cts.

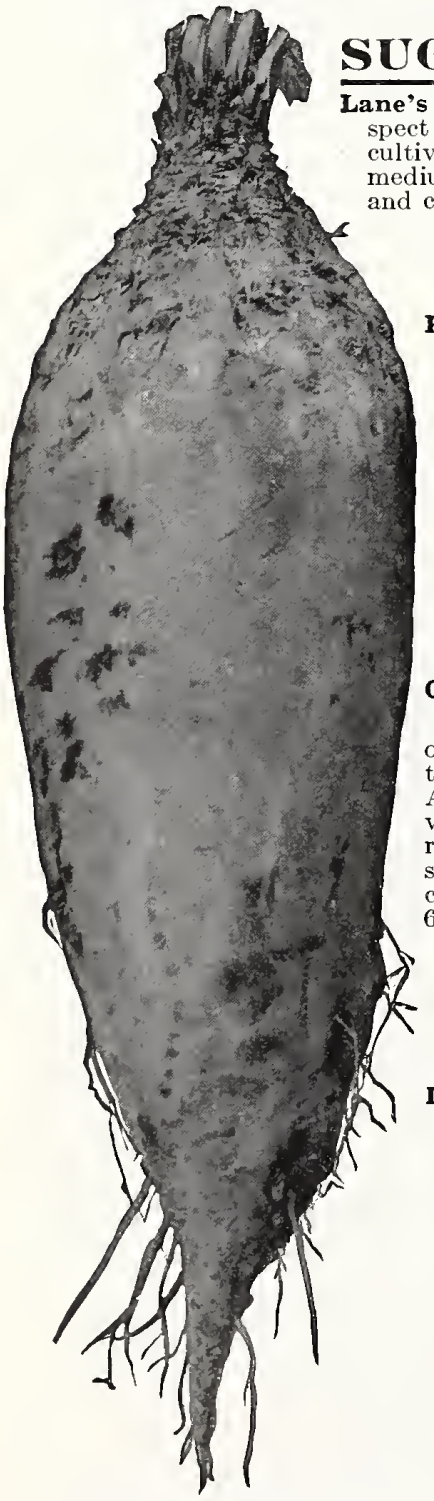

Mangel-Wurzel, Mammoth Long Red

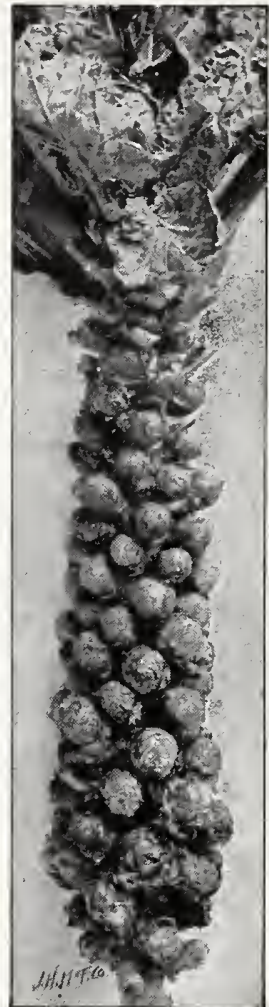

Brussels Sprouts, Long Island Improved

\section{BRUSSELS SPROU'TS}

One ounce will produce 3,000 plants

For early fall use sow seed outdoors in May and during July set plants every 18 inches in rows 2 feet apart. Later sowings may be made in June. The sprouts are far superior in flavor to either cabbage or kale, especially after a hard frost, and from June sowings will be ready for use during the early part of October. Between one and two quarts is the average yield of one plant.

Brunjes' Long Island Improved. The stems riety grow about 2 feet high and are covered with cabbage-like sprouts about $1 \frac{1}{2}$ inches in diameter. Unsurpassed in quality. A selected strain of unusual merit and well worth a trial in every garden. Pkt. 10 cts, oz, 30 cts, 1 lb, 90 cts, lb. $\$ 3$.

Improved Dwarf. Early and of dwarf habit, but the heads are large, sweet and tender. Pkt. 5 cts., oz. 25 ets., $\frac{1}{4}$ lb. 75 cts., lb. $\$ 2.50$.

BORECOLE. See Kale.

\section{GHERVIL}

\section{One ounce will sow 100 feet of drill}

The Chervil resembles the parsley in appearance, and is highly esteemed for flavoring and garnishing dishes of meats and vegetables. Seed may be sown early in spring, but when the plants are quite large they should be transplanted about 10 inches apart.

Curled. The leaves when young are superior to parsley and prized for their delicious flavor. Usually in about 10 weeks after the seed is sown the leaves are ready for use. They are densely curled and not so large as parsley. Pkt. 5 cts., oz. 15 cts., $\frac{1}{4} \mathrm{lb} .40 \mathrm{cts.}$, lb. $\$ 1.25$.

\section{CHICORY} immense cropper, often vielding from 15 to 18 tons to the acre. Oz. 10 cts., $\frac{1}{4} \mathrm{lb}$. 25 cts., 1 b. 75 cts.

\section{BORAGE}

One ounce will sow 50 feet of drill

The leaves have a cucumber-like odor, and are used as a salad. Sow the seed in drills 1 foot apart from April until August and when well advanced thin out to 3 inches in the row. As it soon runs to secd, make sowings every two weeks for a succession. Pkt. 5 cts., oz. 20 cts., $\frac{1}{4} \mathrm{lb}$. 60 cts., lb. $\$ 2$.

\section{BROCGOLI}

One ounce will produce 3,000 plants

Italian Green Sprouting. A very useful variety adapted for growing in spring, summer, or fall, resembling cauliflower only in shape or formation, as the color is dull bluish green. For early use, seed may be sown in hotbeds during March and later transplanted outdoors in rows 2 feet apart and 18 inches apart in the row. After the central head is cut, the plant produces many branches, each terminating in smaller heads which are equally as desirable as the larger head. Served in the same way as asparagus, they form a very tasty and nourishing dish. Considered by some to be supe. jor to cauliflower in quality
One ounce will sow 100 feet of drill. Four pounds will sow an acre

The seed may be sown in drills 1 foot apart as early in the spring as the ground can be worked. When the plants are 3 to 4 inches high they should be thinned out so that they stand 5 inches apart. When grown in the home-garden Chicory should be blanched similar to celery. It is grown differently by market-gardeners who sow the seed in August for usc the following spring when the leaves are cut off and bunched in the green state.

Witloof. The leaves are generally blanched, similar to celery, and in this way make an excellent salad. Pkt. 5 cts., $0 z .25$ cts., $\frac{1}{4}$ lb. 75 cts., lb. $\$ 2.50$.

\section{CHIVES}

Hardy perennial plants which with little protection may remain outdoors during the winter. They appear very early in spring when the small, fine, green leaves are cut and used for flavoring salads and also in soup. Has an onion-like flavor. Should be planted in clumps. Pkt. 10 cts.

\section{BUSH BEAN BOUNTIFUL}

For an early, flat, greenpodded Bush Bean of the highest quality, try Bountiful.

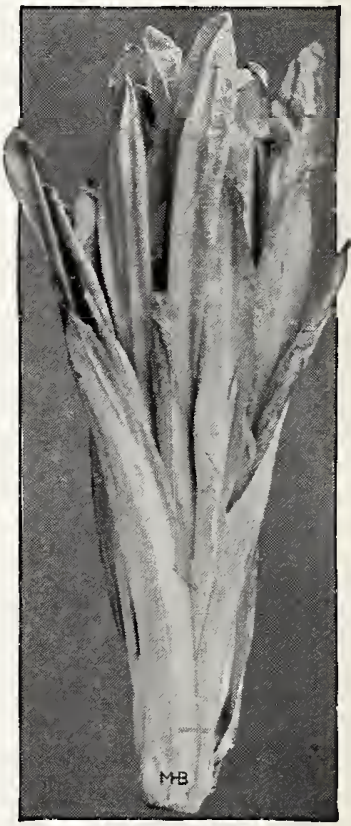

Chicorv, Witloof 


M. H. BRUNJES \& SONS F⿸厂 BROOKLYN. N. Y. BS RELIABLE SEEDS

\section{GARROT}

One ounce to 100 feet of row

A light, loamy soil that has heen well manured the previous year is preferred for growing Carrots, although good crops may also be obtained froun ordinary garden soil. For early use seced may be sown in hotheds from Jamiary until March, and in the open ground as soon as the weather becomes warm and settled, usually in April. Sow seed $\frac{1}{2}$ inch deep in rows 15 inclies apart, and later thin to 5 inches in the row: licep scril between the rows well hocd and free from weeds. From July 1 to 15 sow ful winter crops

Chantenay. An ideal, mediumearly, stump-rooted ('arrot; smooth and uniform in shape, averaging 5 inches in length, with thick, heary shoulders, rsther large tops and deep orange color 1 , is a good variety whether for carly or late sowing, of excellent quality ancl highly recommended for either the market or private wardener. I'kt. 5 cts., oz. 15 cts., $\frac{1}{4}$ lb. 40 cts., ib. $\$ 1.25$.

Parisian Forcing. Extremely early; of small size but very swect; tender and beautiful orange-red color. 1"kt. is ("ts., oz. 20 ("ts., 3h). 60 c'ts., lb. 52

Guerande, or Oxheart. A short, thick ('arrot, not excecting 4 inches in lengtls and about the same in width, which does quite well on hard, heary soils where the longer

Pkt. 5 cts., oz. 15 cts., 신 lb. 40 cts., 1b. $81.2 \bar{J}$.

Half-Long Nantes. (Stmu-rooted.) The roots of this farorand tender, of undium size and bright orange eolor. It has small tops and is larenely used for sowing early in the frames and the one

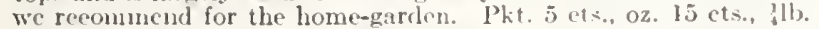

Danvers Half-Long. (Sitump-rooted.) Owing to its enormous viold this variety is

40 cts., lb. $\$ 1.25$.

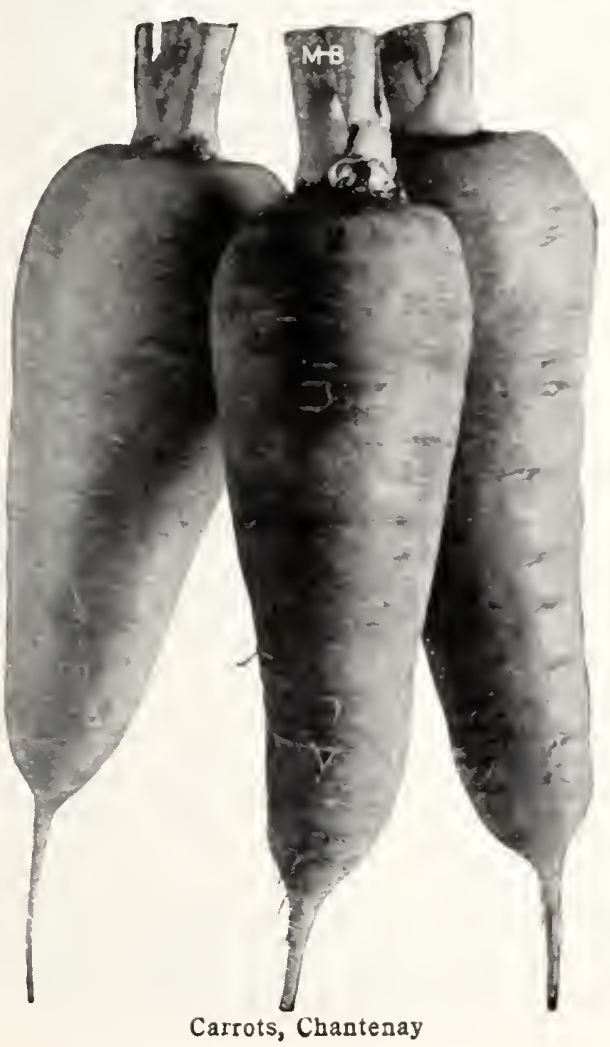

the best and most profitable for main erop, and espeeially drirable for feeding cattle. It is somewhat longer, thirker and a better keeres than the Chantenty, and can be depended upor to give entire siltisfaction. I'kt. $\overline{3}$ ets., 0z. 15 cts., $\frac{16}{4} \mathrm{~b} .40 \mathrm{cts}, 1 \mathrm{~b} . \$ 1.25$.

Long Orange Improved. A favorite market varicty which is late in maturing and very productive it the top the roots are about 3 melacs in diametior ind often measure a foot in length, gradually tapering to a print. They are deep orange in color, good keepers, and have sweet, tendre fiestr. A deep. mellow soil is leest suited for their culture. I'kt. 5 its., oz. 15 ct..., ? lb. 40 ets., 1b. s1.25.

Rubicon. One of the finest half-long, stump-ronted Carrots, quite similar to the lmproverl 1)anvers in shape and size, and of dere?, rich, orange-red color. It is a good kecper and maturen al litule luter than (hintenay. Pht. 5 cts., oz. 15 cts., 31 b. 10 ets., lb. $\$ 1.25$.

\section{CARDOON \\ One ounce for 300 plants}

An esteemed ceterv-like vegetable, the stalks of which are blanehed and used for flavoring soups or stews. Sow during April or May in drills 12 inches apart, later thinning to 6 inches in the row. Leave roots in ground until following spring, then transplant into trenehes $2 \frac{x}{2}$ feet apart and 1 foot in the row, where they will remain for several years.

Large Solid. Grows almost 4 fect high, and has smooth leurcs. P'kt. $5 \mathrm{cts}, \mathrm{Oz} .25 \mathrm{cts.}, \frac{1}{1} \mathrm{lb} .75 \mathrm{cts}, 1 \mathrm{~b} .82 .50$.

\section{COLTARDS}

One ounce for 3,000 plants

A variety of cabbage forming onl $y^{*}$ a mass of leaves instead of a solid head, but which is extermed most highly and extensively grown in the South. Sow seed about the same as cabbage and later transplant 1 foot apart in rows $2 \frac{1}{2}$ feet apart. Sowings are made in the South from January to May and again in carly fall.

True Georgia (Southern Crcole). Vigorous and productive, growing from 2 to 3 feet high. Pkt. 5 cts., oz. 20 cts., $\frac{8}{4} 1 \mathrm{~b} .50$ ets., $1 \mathrm{~b}$. $\$ 1.50$.

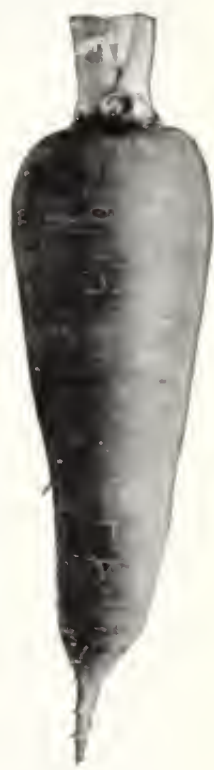

Carrot, Half-Long Nantes 


\section{CABBAGE}

One ounce will produce 3,000 plants

Almost any soil whether a light sandy loam or heavy clay, if properly prepared, will be suitable for growing Cabbage, but a rich loam with a gravelly subsoil is undoubtedly the best. Plants of the earlier varieties should be started in February and from then until June for a succession. To obtain strong, stocky plants the seedlings should be transplanted at least once before the final planting, when they are set from 1 to 2 feet apart in rows 2 to 3 feet apart, according to the variety. Insects are quite troublesome to plants grown in the open ground. Therefore, after sowing, sprinkle a small quantity of tobacco dust over the seed and also keep the young plants well covered until ready for planting. Thorough cultivation is necessary for best results.

Brunjes' Long Island Flat Dutch. A selected strain, early or late planting and maturing about two weeks after Early Spring. The heads are medium in size but very heavy and solid, and owing to its sure heading and good keeping qualities it is a favorite, and largely planted by Long Island market-gardeners. Pkt. 10 cts., oz. $\$ 1.25, \frac{1}{4}$ lb. $\$ 4$, lb. $\$ 15$.

Allhead Early. The heads are large, round, flat, very solid and uniform in size. It is a good keeper of fine quality, and almost certain to head under any favorable conditions. Pkt. 5 cts., oz. 35 ets., $1 / 4$ lb. $\$ 1.15$, lb. $\$ 4$.

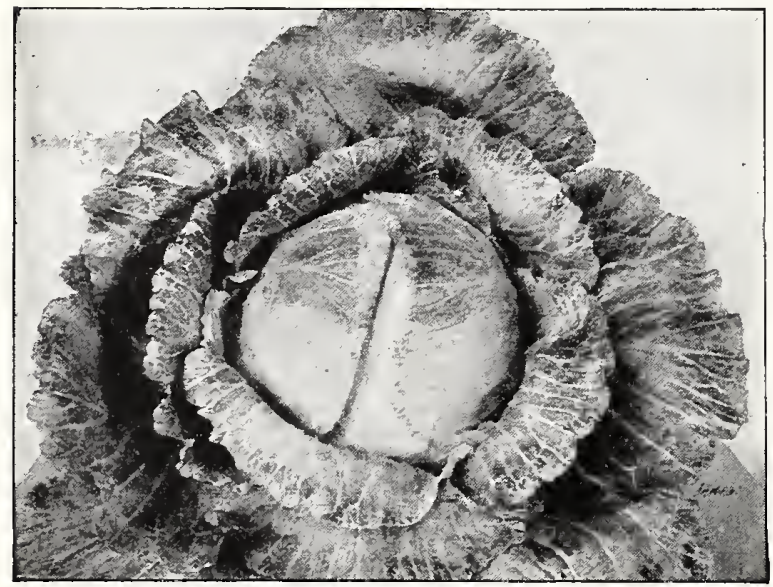

Cabbage, Succession

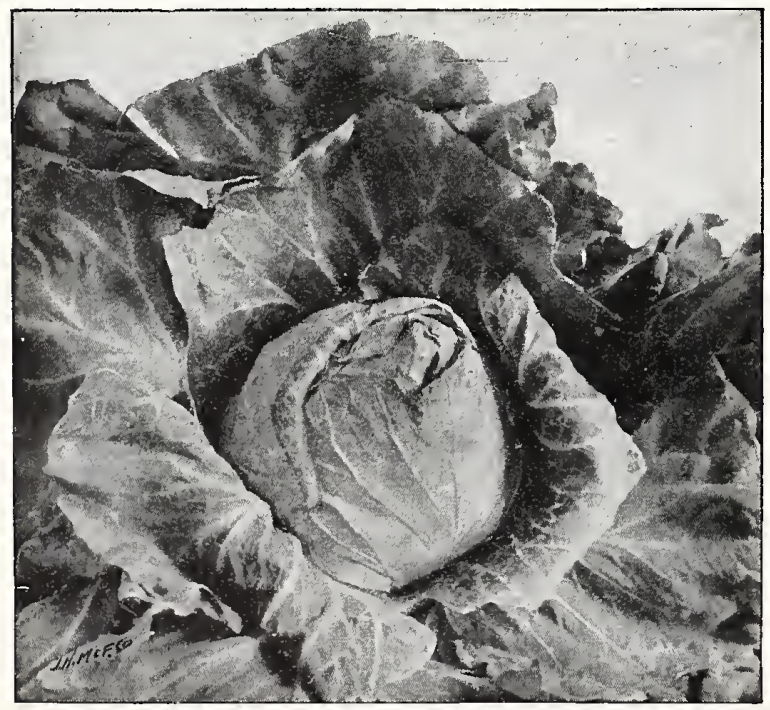

Cabbage, Charleston Wakefield

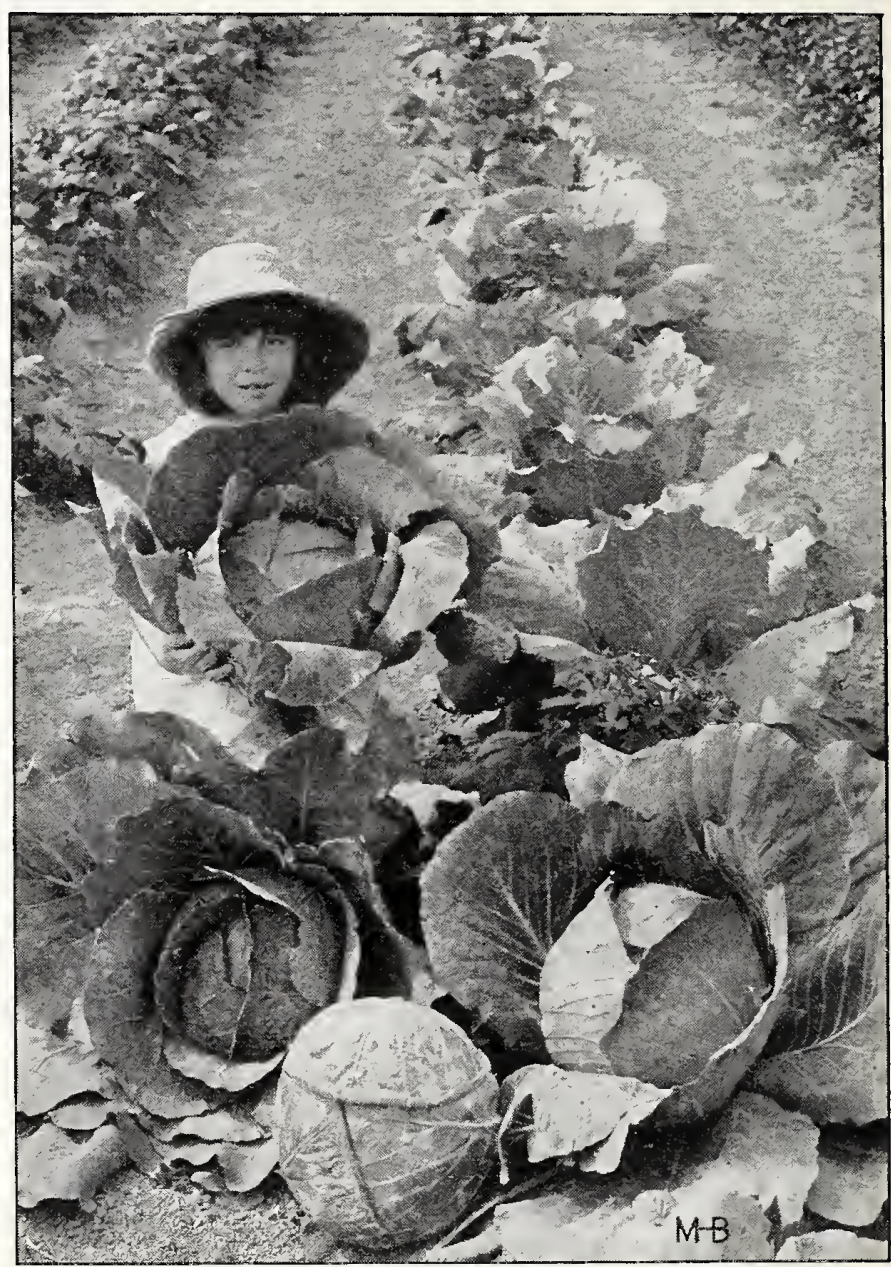

Cabbage, Brunjes' Long Island Flat Dutch

All Seasons. One of the best second-early sorts, but will also give equal satisfaction for late or intermediate planting. It withstands hot, dry weather remarkably well, forming large, solid heads, which in sweetness and tenderness may be classed with the best. Pkt. 5 cts., oz. 35 cts., $1 / 4 \mathrm{lb}$. $\$ 1.15,1 \mathrm{~b} . \$ 4$.

Charleston Wakefield. Although a few days later than the Early and equally good in quality. Invaluable for gardens where close planting is usually necessary. Pkt. 5 cts., oz. 35 cts., 1/4lb. $\$ 1.15$, lb. $\$ 4$.

Danish Ballhead, or Hollander. An excellent Cabbage for winter use, having round, medium-sized heads, as solid as a rock, which remain in splendid condition until spring. Very hardy, of compact growth and withstands the cold better than any other variety. Superior for shipping. Pkt. 5 ets., oz. 50 cts., $1 / 4$ lb. $\$ 1.60$, lb. $\$ 6$.

Early Jersey Wakefield. This is the earliest Cabbage in our list and while not so large as later sorts, it is nevertheless one of the very best for early planting. The heads have few thick, outer leaves, are conicalshaped, very firm and solid and equal to any in quality. Pkt. 5 cts., oz. 35 cts., 1/4lb. $\$ 1.15$, lb. $\$ 1$.

Surehead. A good-keeping and highly recommended Cabbage of the Flat Dutch type. The large, solid heads of excellent quality weigh from 10 to 15 pounds, are somewhat flattened at the top, and have many outer leaves. It is largely grown as a winter Cabbage for shipping, and is one of the surest-heading varieties in our list. Pkt. 5 cts., oz. 35 cts., $1 / 4 \mathrm{lb}$. $\$ 1.15,1 b . \$ 4$.

Brunjes' Early Spring. The earliest, flat-headed variety, which Jersey Wakefield, but matures more evenly and also produces far more Cabbage to the acre. The heads, of medium to large size, form close to the ground, and have few very smooth dark green, outside leaves. Our strain of this variety is exceptionally fine. Pkt. $10 \mathrm{cts}$., oz. 85 cts., $\frac{1}{6} l \mathrm{lb}$. $\$ 3,1 \mathrm{~b} . \$ 11$. 


\section{GABIBAGE, continued}

Copenhagen Market. We consider this the best early, round-headed Cabbage, maturing most valuable variety with our Long Island gardeners. It grow compactly, allowing elose planting: has large, round, solid heads of the finest quality, often weighing 10 to 12 pounds. Pkt. 5 cts., oz. $60 \mathrm{ets}, 1 / 4 \mathrm{lb}, 82.25, \mathrm{lb} . \mathrm{s}$.

Glory of Enkhuizen. A well-recommended medium-early Cabbage for the home-garden. The plants are pale green in color and form large, round, sery attraetive, ball-shaped heads: thin ribbed but hard and solid. P'kt, 5 cts, oz, 40 (cts. 1/11), \$1.40, H), \$5.

Improved Early Summer. Early and sure-heading variety. Heads light green in eolor; firm, of goorl quality and seldom burst.

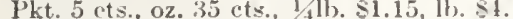

Premium Flat Dutch. An esteened late Cabbage that is well suited for winter storing. IIeads are hard, perfect in shape, and attain large size. I'kt. 5 cts., oz. 35 cts., 1 $11 \mathrm{~b}, \$ 1.15$, ll. $\$ 1$.

Succession. In every respect a model variety. It may be Succession. planted at all seasons but will give best results when used as a second-early or intermediate sort. $A$ sure header, of medium size, and finest quality. Pkt. 5 cts., oz. 35 cts., $3 \mathrm{lb} . \$ 1.15$, lb. $\$ 4$.

\section{SAVOY CABBAGE}

Brunjes' Long Island Savoy. The finest of all Savoy Cabits round, deep, uniform heads, which are very large, beatutifully curled and unsurpassed in quality, Like our Long Island Flat Dutch it is a sure header, excellent keeper and the very best for the market or home-garden. Pkt, $10 \mathrm{cts}, 0 z, \$ 1.25,1 / 11$ ), $54.50,1 \mathrm{~b}, \mathrm{~s} 17$.

Early Dwarf Ulm Savoy. An early variety with solid heads of medium size; very sweet and tender. $\mathrm{I}^{\mathrm{h}} \mathrm{t} .5 \mathrm{ets}, 0 \mathrm{z} .35 \mathrm{ets} ., 1 / 4 \mathrm{~b}$. $\$ 1,15,16 . \$ 4$.

American Drumbead Savoy. One of the best Savoy Cabbages for general use, with fine-curled, dark green leaves and large, firm heads of good quality. Pkt. 5 cts., oz. 35 ets., 1/4 lb. $\$ 1.15$, 1b. \$4.

Perfection Drumhead Savoy. Splendid for late planting. The heads are large, solid and keep well through winter. Its fine appearance always commands the highest price in market. Pkt. 5 ets., oz. 35 ets., $1 / 4$ lb. $\$ 1.15$, lb. $\$ 4$.

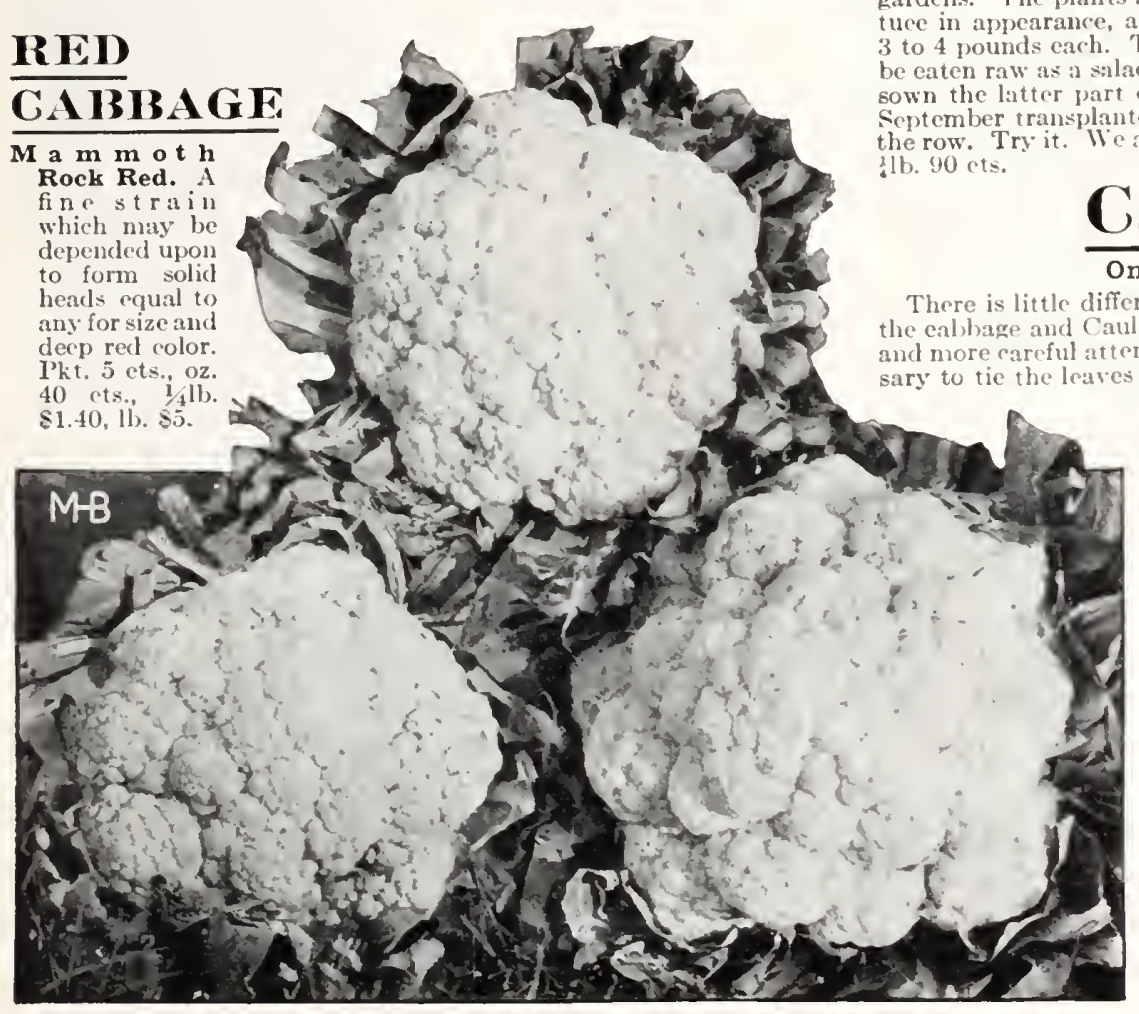

Cauliflower, Early Snowball

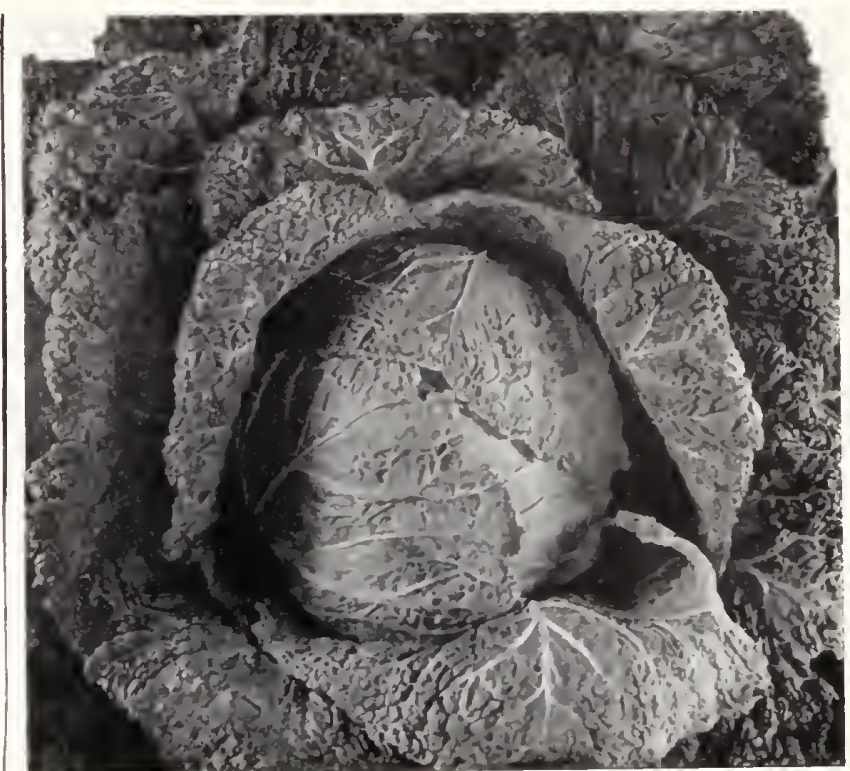

Cabbage, American Drumhead Savoy

IRFI) GAIBIBAGL, continued

Large Red Drumhead. A very goorl varicty having round, dark red heads, solict and excellent for pickling. I'kt. 5 ets., oz. 40 ets. $1 / 1 \mathrm{~b}, 81.40,1 \mathrm{~b}, 85$.

GA BHA GE PLANTS. See page 28.

\section{Pe-'Tsai, Chinese or Gelery Gabbage}

This Chinese vegetable is becoming quite popular in the American gardens. The plants are of upright growth, very much like Cos lettuce in appearance, and the heads when fully natured often weigh to 4 pounds each. 'The inner leaves blanch creamy white and may as or eooked like asparagus. The seed should be

\section{Cauliflower}

One ounce for 2,000 plants

encenting the eulturat directions between flower, only that the latter requires richer soil forerent bleaching by the sun Brunjes' Erfurt Dwarf Earliest. fower of the highes guality auch one that is eertain to withistand the test of the most critical grower. It is not only superior for forcing, but stececls jo as wer to form large, handion de. heads of delicious flavor.

oz. $\$ 1.25,0 z .54$

Early Snowball. A sure header, carlier than the Extra-Early Dwarf Erfurt; plants compact in growth with few small outer leaves which allows close planting. Splendid for the private garden where space is often limited. Pkt. 15 c ${ }^{\circ} \mathrm{s}, \mathrm{Oz}, \$ 2.50$.

Extra-Early Dwarf Erfurt. An early, wellknown fayorite, especially reconmended to all desiring a cauliflower of medium size, Pkt, 15 cts., oz. $\$ 2.50$.

GAIIIFIOWHIR MIAATS. page 2 ? 


\begin{tabular}{|c|c|c|}
\hline M. H. BRUNJES \& SONS & BROOKLYN, N. Y. & RELIABLE \\
\hline
\end{tabular}

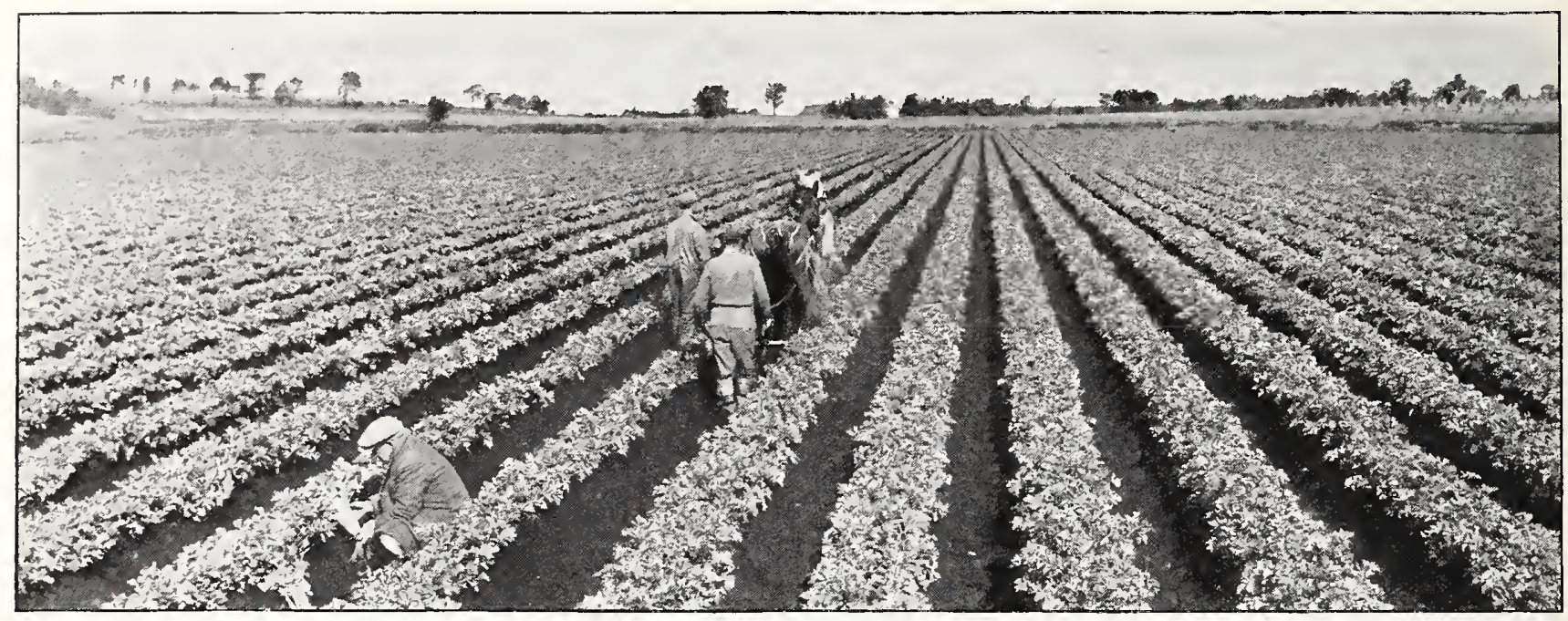

Celery, Golden Self-blanching

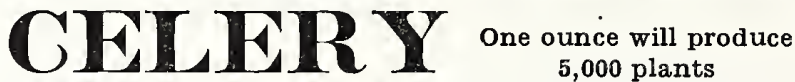

During April or May sow seed ${ }^{1} 4$ inch deep in drills, either in the open ground or coldframe, keeping the soil well moist until seed germinates. When the plants are about 2 inches high, thinning out is necessary, and then after attaining a height of 5 inches they are ready to be transplanted, usually in July, to final beds of very rich soil. Set plants every 6 inehes in rows 3 feet apart. Keep space between rows cultivated and free from weeds. For early use begin blanching in Scptcmber by drawing up the soil to within a few inches of the top and firm well around the plants. Select every other row for early use, thus giving the remaining Celery more room for late blanching.

Golden Self-blanching. This early, self-blanching Celery compares with any in quality, and with little banking the handsome, solid the home or market-gardener. We offer true French-grown stoek, and there is none better. Pkt. 10 ets., oz. 75 cts., $1 / 4$ lb. $\$ 2.50$, lb. $\$ 8$.

White Plume A variety especially adapted to eultivation by amateurs as its White Plume. inner stalks and leaves are naturally white, and do not require blanching by the old process of high banking. By simply tying up the stalks and drawing up the soil with the hoe, the work of blanching is complete. It is tender, crisp and of good flavor. Pkt. 5 ets., oz. 40 ets., 1/4lb. $\$ 1.25,1 \mathrm{~b} . \$ 4$.

Columbia. Words of highest praise have been received from growers of this new Celcry. Stalks thick and stoeky, well shaped and when blanched resemble the Golden Self-blanching. Pkt. 5 ets., oz. 40 ets., $1 / 4$ lb. $\$ 1.25$, lb. $\$ 4$.

French's Success. A new green Celery of compaet growth, possessing the finest flavor and recommended for its keeping qualitics. Pkt. 5 ets., oz. 40 ets., $1 / 4 \mathrm{lb}$. $\$ 1.25,1 \mathrm{~b} . \$ 4$

Giant Pascal. A most desirable early winter variety having broad, stringless stalks which blanch quickly to a beautiful creamy white. Pkt. 5e., oz.20c., 1/41b. 60c., 1b. $\$ 2$.

Schumacher. A reliable variety with comparatively large stalks; solid but erisp and tender. Pkt. 5 ets., oz. 20 cts., $1 / 4$ lb. 60 cts., lb. $\$ 2$.

Soup or Cutting. This variety is adapted to sowing thick in rows and eutting when 5 or 6 inches high, to use for soup-flavoring. It can be eut repeatedly and will furnish a succession throughout the season. Pkt. 5 cts., oz. 20 cts., 1/4lb. 60 ets., lb. $\$ 2$.

Winter Queen. As a winter-keeping Celery there are few that ean compare with this superior variety. It is noted not only for its good kecping qualities, but also for the thick, heavy stalks, almost all heart, which blanch to a creamy white and possess that rich nutty flavor so much desired in Cclery. Pkt. 5 ets., oz. 20 ets., ${ }_{1}$ lb., 60 cts., lb. $\$ 2$.

CELERY SEED FOR FLAVORING. Oz. 5 ets., 1/41b. 15 cts., lb. 50 cts. CELERY PLANTS. See page 28.

\section{CELERIAC (Turnip-rooted Celery)}

This vegetable is grown principally for its bulb-like roots, the flavor of whieh is highly estcemed in soups and stews. For early use, first sowings are made in frames the becinning of March, but outdoor sowings during April and May are reeommended if roots are desired for winter. Like Celery, sow seed $1 / 4$ inch deep in drills 10 inches apart, and when plants are stocky transplant to beds of rich, dcep soil, 6 inches apart in rows $11 / 4$ feet apart. Cultivate thoroughly and remove but little of the greens until the bulb is of good size.

Large Smooth Prague. The finest of all Celeriae. Roots measure from 2 to 4 inches in diameter; round, smooth with eomparatively few side roots. Pkt. 5 ets., oz. 40 ets., $1 / 4$ lb. $\$ 1.25$, lb. $\$ 4$.

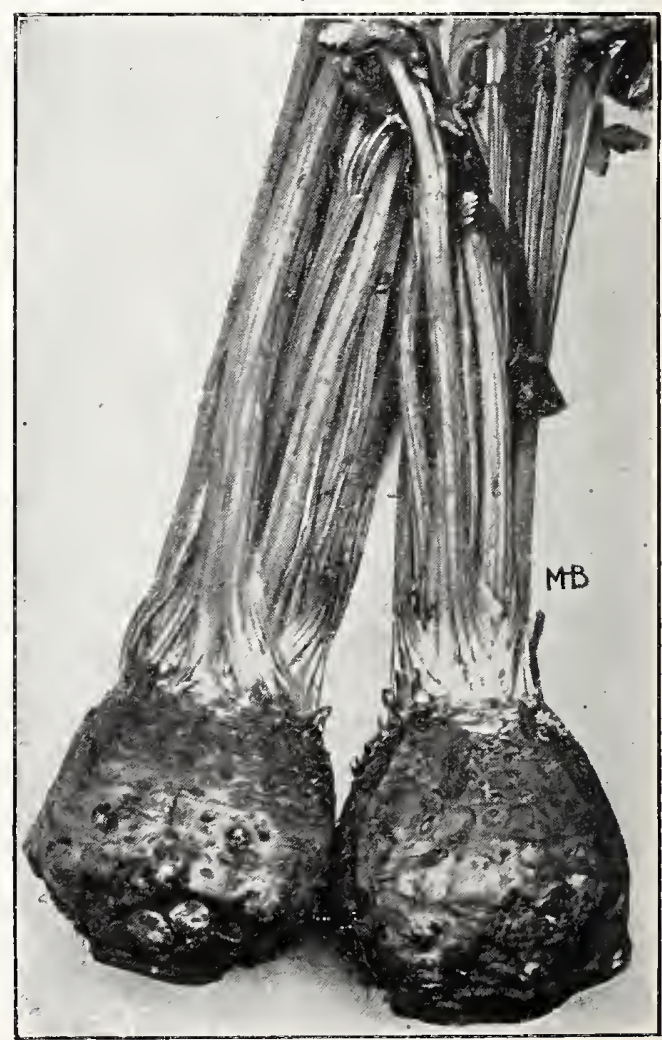

Celeriac, Large Smooth Prague 


\section{H. BRUNJES \& SONS BROK BROOKLYN, N. Y.

\section{CUCUMBER}

One ounce will plant 50 hills

After danger from frost is over, usually early in May, sow seed $\frac{1}{2}$ inch deep in hills not less than 4 feet apart each way, dropping about twelve seeds in each hill. Later, when plants are well started, thin out, leaving only five or six of the strongest to every hill. A rich soil that has been well inanured is most profitable for Cucumbers. Sow seed for pickles during June and July.

Early Fortune. Whether for the farm you will find Firly Fortune just the cu, eumber you want. The fruit is long aurl slightly tapering, averaging 9 inches in length, has firm white flesh and few seeds. It is wonderfully productive and retains its dark green color louger than other white epine varieties. Pkt. 5 ets., oz. 20 ('ts., $\frac{1}{4}$ lb. 50 cts., lb. $\$ 1.50$.

Cool and Crisp. An excellent Cucumber for slieing, but when small is equally grood for pickling. Flesh pure white, tender and crisp. Pkt. 5 ets., oz. 15 cts., $\frac{1}{4} 1 \mathrm{~b} .10 \mathrm{cts}$. 1b. $\$ 1.25$.

Davis Perfect. A type of white spine with favor either for forcing or open $g$ romd eulture. It is a liand so ne, extra-long Cucumber, delightfully flavored and retains its deep glossy green eoloruntil near nuaturity. Pkt.5ets., oz. $15 \mathrm{ets}, \frac{1}{4} 1 \mathrm{~b} .40 \mathrm{cts}, 1 \mathrm{l} .81 .25$.

Early White Spine. For gencral crop this variety may well he Meclium size, beantiful color and keens in gool condition long after picking. Pkt, 5 ets., oz. 15 cts., $\frac{1}{4} 11$ ). 40 ("ts., lb. $\$ 1.25$.

Extra-long, or Evergreen White Spine. This is one White Sine cuenmbers citlor for the narket or private garden. Matures somewlit later tham the Farly White Suine, but exceed it in length: (onully productive and diarker in color. Pkt. 5 ets., oz. 15 cts., 1 b. 40 ets., 11 . $\$ 1.25$.

Green Prolific, or Boston Pickling. Fruits are small, bright green, very smooth and vield an unmsually large mumler of pickles to the? acre. I'kt. 5 ets. oz, 15 ets. ${ }^{1} 1 \mathrm{lb} .40$ ets., 1b. 81.25 .

Improved Long Green. Grows from 10 to 12 inches long, thick, dark green and one of the hest flavored. At maturity the fruits become ricli yellow and are then mstremed for making mustarel Cucumbers. Pkt. 5 (ts., oz. 15 ets., 11 ). 40 cts., lb. $\$ 1.25$.

Klondike. There are many fine Cuenmbers and this is one of them. When ready for use the fruit is about 7 inclues long and 2 inches thick, very dark green in color, of excollent cutality and fine for slicing. Pkt, 5 cts., oz. 15 (ts., 111 ). 40 ('ts., lb. $\$ 1.25$.

Japanese Climbing. A distinet variety which nuay be traincl to a pole or trellis and bearing throughout the summer extra-long, smooth, well-flavored Cucumbers. l'kt. 5 cts., oz, 20 cts., ${ }^{1} l \mathrm{lb}$. 50 cts., 11. s1.50.

Snow's Pickling. Pkt. 5 ets., oz, 15 ets., $\frac{2}{4} 1 \mathrm{~b}, 40 \mathrm{cts}, \mathrm{lb}, 81.25$.

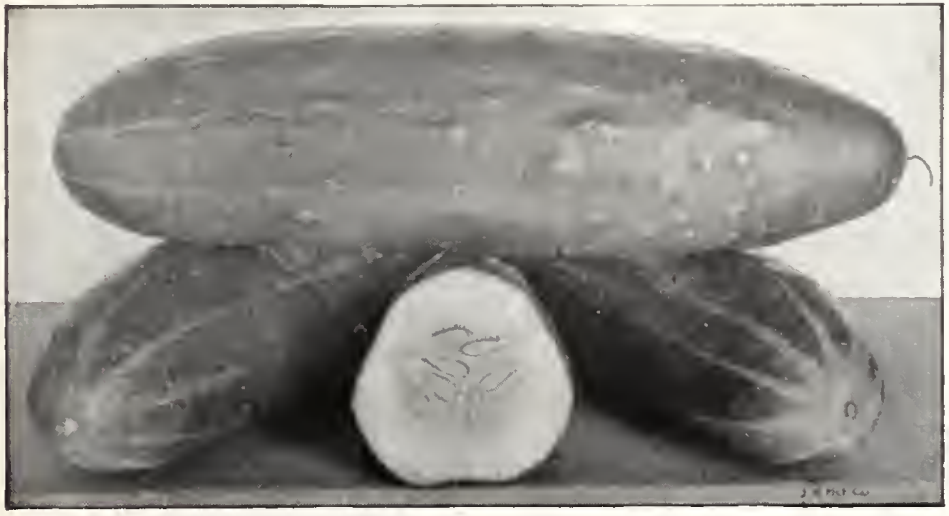

Cucumber, Extra-long, or Evergreen White Spine

\section{GORN SAIAD O One ounce will sow}

This small green salurl, so often ealled Irield sialiul, man be had throughout the greater yart of the winter, provicling it is given

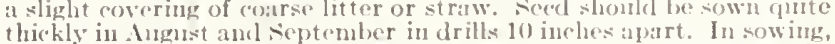
do not cover the seed more than one-fourth inch, but see that the soil is pressed firmly over the seed to hasten germination. A sowing may also be made in early spring.

Large-seeded. Pkt. 5 cts., oz. Ii cts., 1,11), 40 (ts., ll), \$1.25.

\section{CRIESS One ounce will sow}

The secd should be sown early in the spring on rich ground, quite thickly, in shallow drills, about if foot apsirt. For succession, sow erery ten days, as it soon runs to seed. A supply may be had dnring
the winter anouths loy sowing the seed in slrallow looses and placing in a warm, sunny situation.

Extra Curled. The leaves, which have a peculiar taste, are used as a sulicl. 1'kt. 5 cts., oz. 10 ets., ${ }_{4}^{1} 1 \mathrm{~b} .30$ cts., 1b. $90 \mathrm{cts}$.

\section{WA'TER-CRESS}

Requires a moist situation, or, better still, a running strean where secel uny be sown along the banks in spring. It ean be eut the second cear.

Common. Pkt. 10 ets., oz. 30 ets., ⿱1ㄴ). $\$ 1$.

True Erfurt. Superior to the above and of a mileler flavor. Pkt. 10 ets., oz. 40 cts., $\frac{2}{4}$ lb. 81.25 .

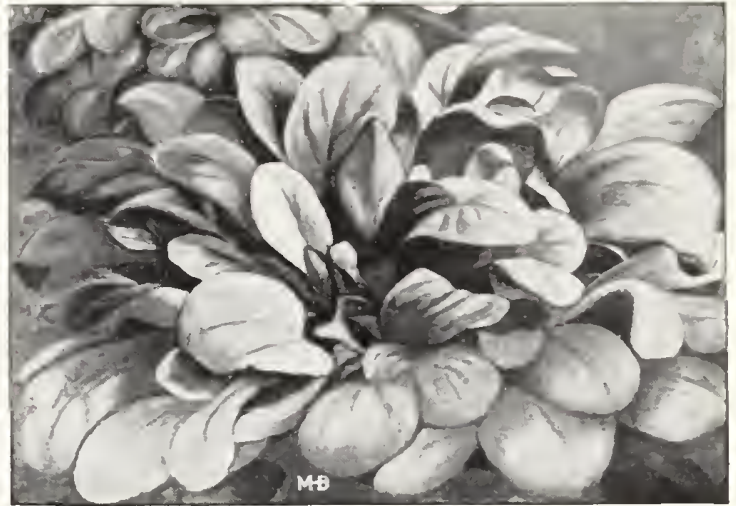

Corn Salad, Large-seedeủ 

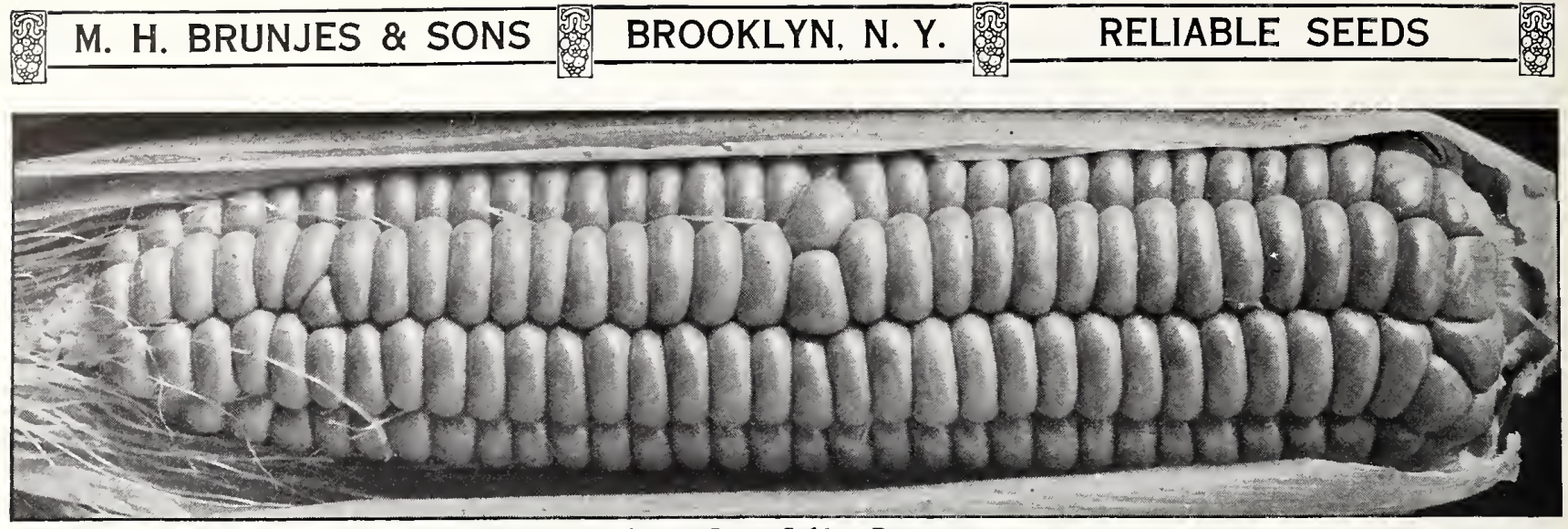

Sweet Corn, Golden Bantam

\section{GORN, Sweet or Sugar}

We have adopted the Cental System in selling Sweet Corn and quote prices by weight instead of measure. One pound is a little more than a pint.

A deep, rich soil is best adaptcd to growing Corn. As it is quite sensitive to cold, planting should be withheld until the ground becomes warm and mellow, usually early in May. Plant in hills from 2 to 3 feet apart according to the variety, dropping about five kernels in each, and cover 1 inch; later thin to three plants to a hill. Cultivate thoroughly between the rows and keep the soil hoed well up to the plants. For a continuous supply during the season, plantings should be made every few weeks until the latter part of July. One pound will plant 300 hills; 12 pounds will plant an acre.

\section{IF BY PARCEL POST, ADD POSTAGE AT ZONE RATE}

\section{EARLY VARIETIES}

Early Mayflower. Gardeners who take pride in having the do well to try Early Mayflower. It matures shortly before Mammoth White Cory; has ears of good size, which are well filled with sweet, tendcr, white kernels. $1 / 2$ lb. 15 cts., lb. 30 cts., 2 lbs. 55 cts., 10 lbs. \$2.50.

Golden Bantam. May be planted at least a week earlier and The stalks grow about 4 feet high, each producing two or more ears measuring from 5 to 7 inches in length. When ready for use the kernels are bright golden yellow, deliciously sweet, richly flavored, and remain tender for some time after ripening. $1 / 2 \mathrm{lb}$. 15 cts., lb. 30 cts., 2 lbs. 55 cts., 10 lbs. $\$ 2.50$.

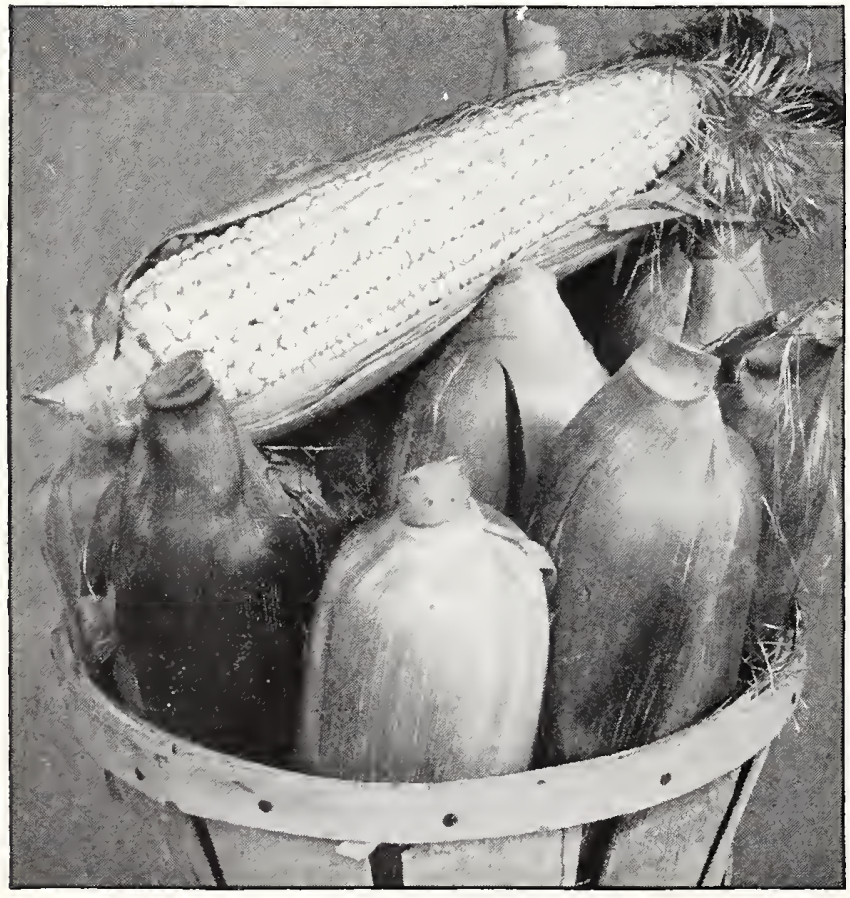

Sweet Corn, Early Evergreen
Bantam Evergreen. This new introduction is one of the finest Bantam Evergreen. and sweetest Corns in our list, and we ask all to give it a trial. The ears, 8 inches long and 12-rowed, are larger than Golden Bantam and the deep, rich, golden kernels just as swcet. $1 / 2 \mathrm{lb} .15$ cts., lb. 30 cts., 2 lbs. 55 cts., 10 lbs. $\$ 2.50$.

Kendel's Early Giant. A valuable early Sweet Corn. The ears grow to a tremendous size, measuring 8 to 10 inches long, and having 10 to 14 rows on each cob, the majority having 12 rows; kernels pure white, swcet, tender. 1/2lb. 15 cts., lb. $30 \mathrm{cts}, 2$ lbs. 55 cts., 10 lbs. $\$ 2.50$.

Mammoth White Cory. An extra-large Corn, considering its extreme earliness. The stallss generally grow 4 feet high, each one usually bearing two ears of good quality. $1 / 2 \mathrm{lb} .15 \mathrm{cts}$., $1 \mathrm{~b} .30 \mathrm{cts}$., 2 lbs. 55 cts., 10 lbs. $\$ 2.50$.

Early Champion. One of the best medium-early varieties. Ears are large, well formed, with clear white, sweet kernels and can be highly recommended for the market or garden. 1/2lb. $15 \mathrm{cts}$., lb. 30 cts., 2 lbs. 55 ets., 10 lbs. $\$ 2.50$.

Early Evergreen. From a week to ten days earlier than Stowell's Evergreen, with somewhat shorter ears but otherwise possessing all the good qualities of that famous Corn. Good market variety. $1 / 2$ lb. 15 cts., lb. 30 cts., 2 lbs. 55 cts., 10 lbs. $\$ 2.50$.

Early Mammoth. A popular Sugar Corn of great merit; earlier than the Late Mammoth and far better adapted for the private garden. The ears, of fine quality, are long but not very thick. $1 / 2$ lb. 15 cts., lb. 30 cts., 2 lbs. 55 cts., 10 lbs. $\$ 2.50$.

\section{SPRAY YOUR PLANTS \\ This New Safe Way}

Ever Green has been thoroughly tested and found effective in controlling the following insects:

Aphis, thrips, moths and their larvæ, leaftier (also called leaf-roller), white fly, rose in. sects, leaf-hopper, red spider, mealy bug, chrysanthemum midge, saw-fly, tarnished plant bug, cabbage and currant worms, and others. 1 -oz. bottle 35 cts., 6 ozs. $\$ 1,16$ ozs. $\$ 2,32$ ozs. $\$ 3.50$, gal. $\$ 11.50$.

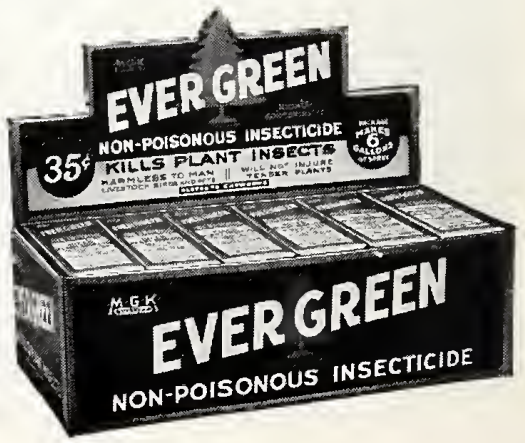




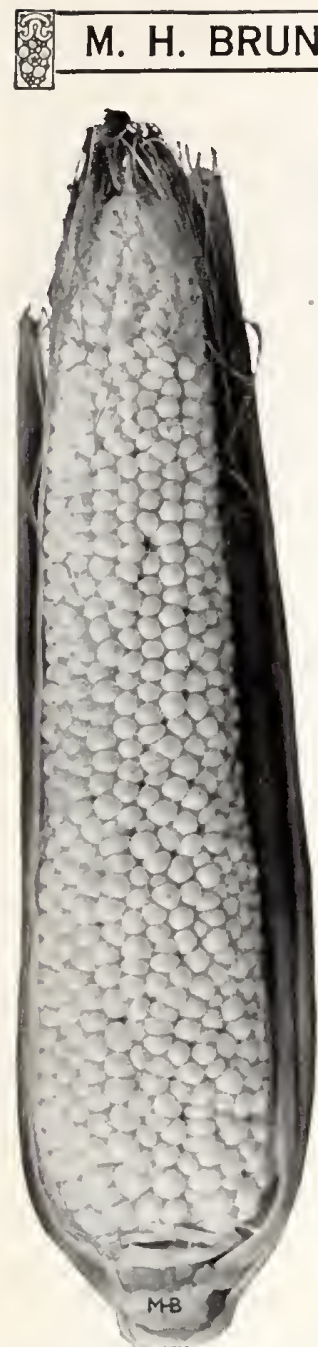

\section{BROOKLYN, N. Y.}

GORN, SWEET or SUGAR, continued

\section{LATE VARIETIES}

Country Gentleman. Quite late in rinening. The long, deep-grainea are the swreetest of any rariety in cultivation, 3 th $15 \mathrm{cts}$, lb. $30 \mathrm{cts}, \mathrm{l}$. $10 \mathrm{lbs} . \$ 2.50$

Stowell's Evergreen. The well-known late sort, and one of the best and thick ears are well filled to the end and remain in condition for cooking longer than most varieties. $\frac{1}{2}$ lb. 15 cts., 1 b. 30 cts., 2 lbs. 55 cts., 10 lbs. $\$ 2.50$.

Brunjes' Long Island Beauty. This splendid sweet Corn is considered It is a ('orn that all should grow, being sweet, very tender, and possessing the rich, sugary flavor of stowell's Exergreen. Ears extra large, often 1 foot in length. 실.b. 15 cts., lb. 30 ct.., 2 lbs. 55 ets., 10 lbs. $\$ 2.50$.

Mammoth Late. Mainly planted by market-gardeners. The stalks grow very ligh, and bear the largest ears of any sweet Corn. Allb. 15 cts., lb. 30 cts. 2 lbs. 55 cts., 10 lbs. $\$ 2.50$.

\section{POP CORN}

Golden Queen. (Shelled.) 1/21b. 15 cts., 1b. $30 \mathrm{cts}, 2$ lbs. 55 cts.

Red Beauty. (Shelled.) 1/2lb. $15 \mathrm{cts} .$, lb. $30 \mathrm{cts}, 2$ lbs. $55 \mathrm{cts}$.

White Rice. (Shelled.) 1/21b. 15 cts., 1b. 30 cts., 2 lbs. 55 cts.

Field Corn. See page 23.

\section{DANIEIION}

\section{One ounce will sow 100 feet of drill}

This is one of the earliest spring vegetables. When small the leaves are very tender and esteened for making salad. Sow the seed in spring, when the soil becones "arm, Msthatly in April, and from then until the middle of August, in rows one foot apart and 'inch deep. It remains over winter and is ready for cutting the following spring. If the roots are not disturbed, they will grow again, a ffording another supply the next year.

French. Common. I'kt. $10 \mathrm{cts.,}$ oz. $20 \mathrm{cts.,}$ 신 lb. $60 \mathrm{cts}, 1 \mathrm{~b}, \$ 2$

\section{I}

One ounce will sow 200 feet of drill

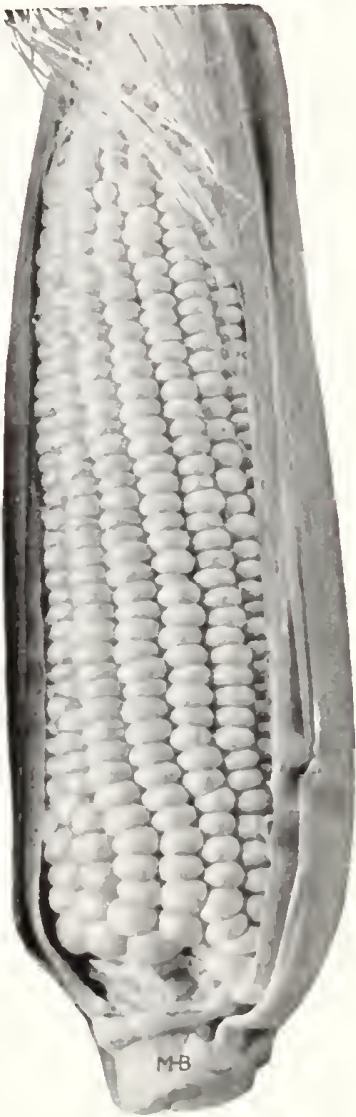

Corn, Stowell's Evergreen

From May 15 to June 15 sow seed thinch deep in drills $1 \frac{1}{2}$ feet apart. Unless the plants stand very thick, it is not necessary to thin out, but keep soil "ultivated and free from weeds.

Brunjes' Mammoth. Far superior to the Common variety, and grown largely by our farmers for the

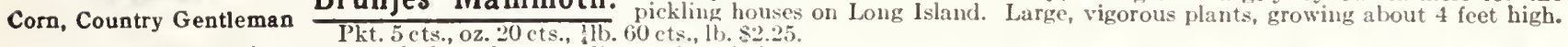
Common. While of dwarfer growth than the preceding variety, it is best suited for the home-gardcn; splendid for flavoring pickles. Pkt. 5 ets., oz. 10 ets., 닌 b. 30 cts., lb. $\$ 1$

\section{Eggiplant}

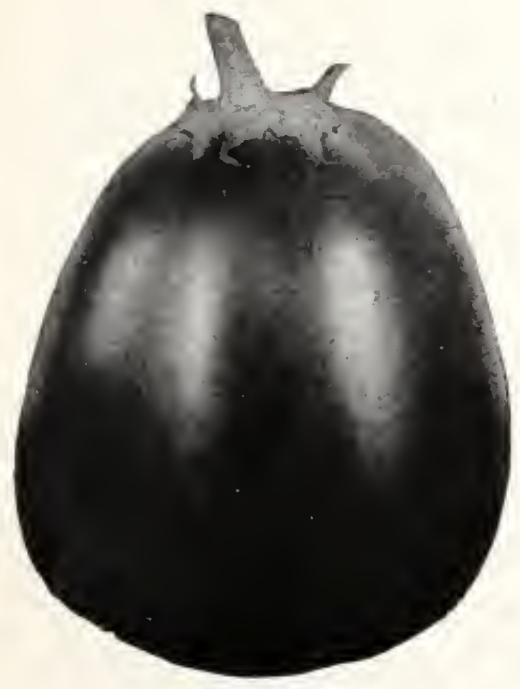

Eggplant, Black Beauty
One ounce will produce 1,000 plants

As the seed of Eggplant is slow in germinating. it should be sown in a lotbed or greenhouse where it will receive the benefit of as much heat as possible. Sow seed during February and the early part of March, and as the plants are very sensitive, they should not be transplanted to the open ground until June, when all danger of cool weather is past. The plants should be transplanted at least once in the frames before the final setting out. Set plants $2 \frac{1}{2}$ fect apart each way.

New York Improved Purple. This is not only the finest Eggplant for the garden, but it is the largest and most profitable for the market as well. The plants are spineless, very productive, yielding from four to six extra-large, oval-shaped fruits of a beautiful rich purple. It is early, and of the finest quality. Pkt. 10 cts., oz. 50 cts., $\frac{1}{4} 1 \mathrm{~b} . \$ 1.90,1 \mathrm{~b} .87$.

Blaek Beauty. Although this varicty is not quite so large as the well-known New York Improved Purple, it matures from a ricek to ten days earlier. The fruits have thick flesh and are very attractive in appearance, being of a rich, glossy, purplish black color. Plants are of strong, stocky growth and very productive. Pkt. 10 cte. oz. 60 cts., $\frac{1}{4}$ lb. $\$ 2,1 b . \$ 7.75$.

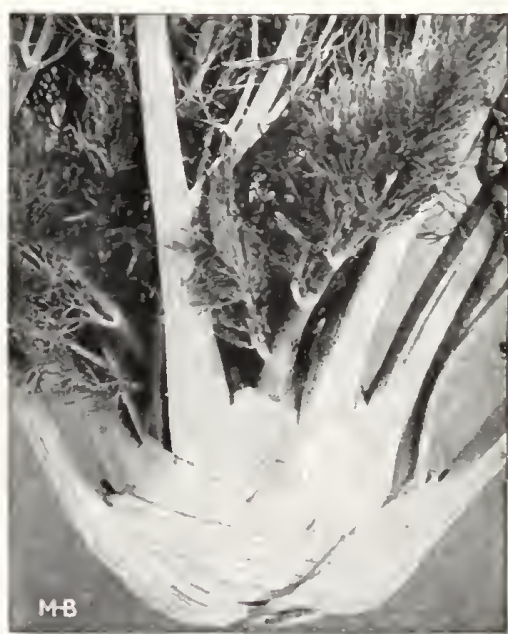

Fennel, Florence (see page 14)

FOR PLA NTS, see page 28. 


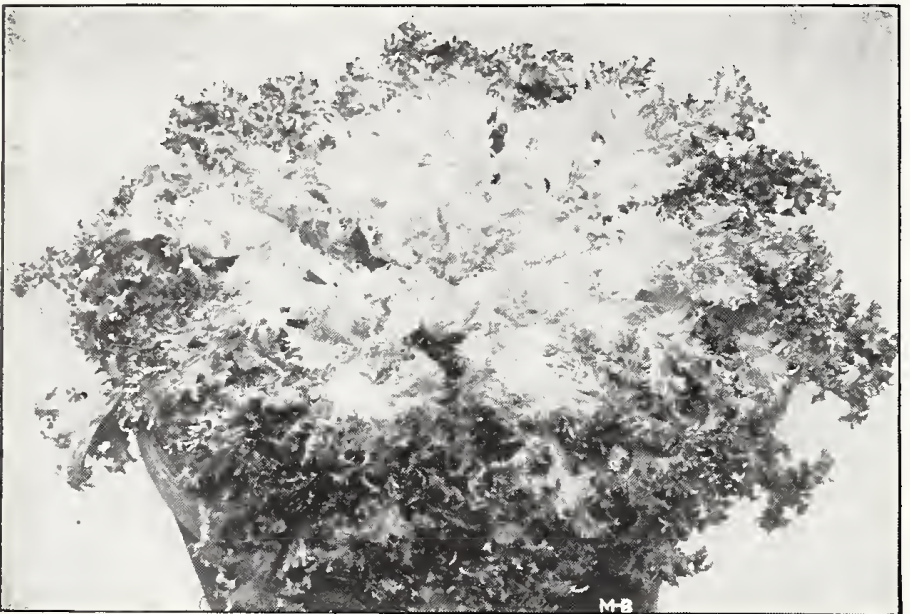

Endive, Large Green Curled

\section{Endive}

Sow seed $\frac{1}{2}$ inch deep in rows 12 inches apart from May 15 until the middle of August. After the plants are well advanced they should be transplanted in rows 15 inches apart and 12 inches apart in the row, thus securing larger heads than if only thinned out. When nearly full grown, draw the leaves together and tie at the top to blanch the heart.

\section{Brunjes' Large Green Curled (Chieory). Leaves are quite} deeply laciniated and form broad, beautifully curled, a creamy white. There are several inferior varieties of this Endive being offered and a trial of our stock will prove its superiority. Pkt. 5 ets., oz. 20 ets., $\frac{1}{4}$ lb. 50 ets., lb. $\$ 1.50$.

White Curled. An ideal variety for the private garden. Leaves very tender, especially striking in appearance and blanch somewhat easier than the above. Pkt. 5 cts., oz. $20 \mathrm{cts}$., $\frac{1}{4} 1 \mathrm{lb} .50 \mathrm{cts}$., lb. $\$ 1.50$.

Broad-leaved Batavian (Escarolle). An excellent strain with thick, broad leaves, slightly curled; bright green at first, but when blanched the heart becomes white and crisp. Pkt. 5 ets., oz. 20 cts., $\frac{1}{4}$ lb. $50 \mathrm{cts}$, lb. $\$ 1.50$.

KOHLRA BI PLANTS. See page 28

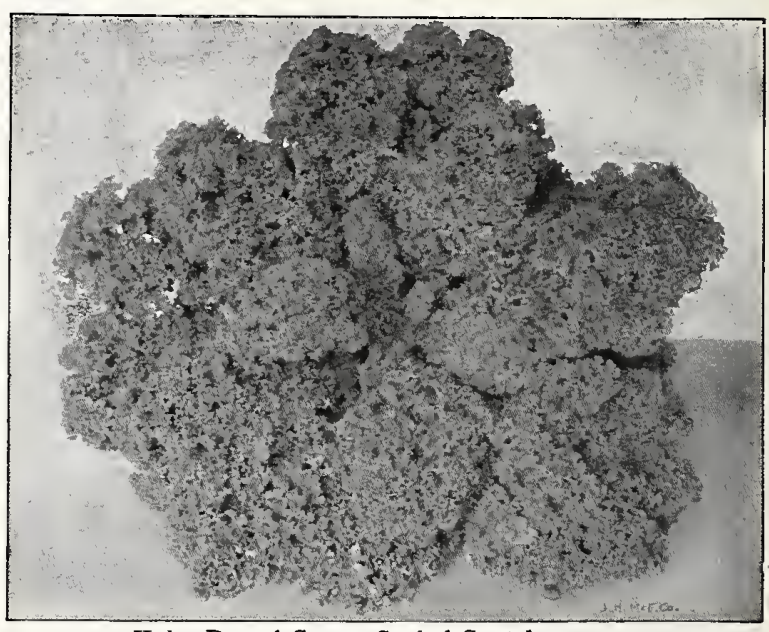

Kale, Dwarf Green Curled Scotch

\section{Kale, or Borecole}

\section{One ounce will produce 3,000 plants}

This vegetable may be had at almost all seasons of the year, but it does not reach perfection until the winter months. For summer use sowings are made in April, while for winter greens June is the best month. Sow in drills $\frac{1}{4}$ inch deep, and later reset plants 2 feet apart each way.

Dwarf Green Curled Scotch. Noted for its extreme hardiness, dwarf, compact habit and extra-fine curled leaves. Pkt. 5 cts., oz. 15 cts., $1 / 4$ lb. 40 cts., lb. $\$ 1.25$.

Tall Green Curled Scotch. Heads are formed on stalks $21 / 2$ feet high; color bright green and leaves exceedingly curly. Pkt. 5 cts., oz. 15 ets., $1 / 4$ lb. 40 ets., lb. $\$ 1.25$.

Dwarf Brown. Similar in growth to the Dwarf Green Curled Scotch. The leaves are purple in color, tender and preferred by many to that variety. Pkt. 5 cts., oz. 20 cts., $1 / 4$ lb. 50 cts., lb. $\$ 1.50$.

\section{SIBERIAN KALE, OP SPROUTS}

There is little difference in taste and flavor between Kale and Sprouts. The former is ready for use during the fall and winter months, while the latter ean only be used the following spring. Sow seed during August in drills 1 foot apart.

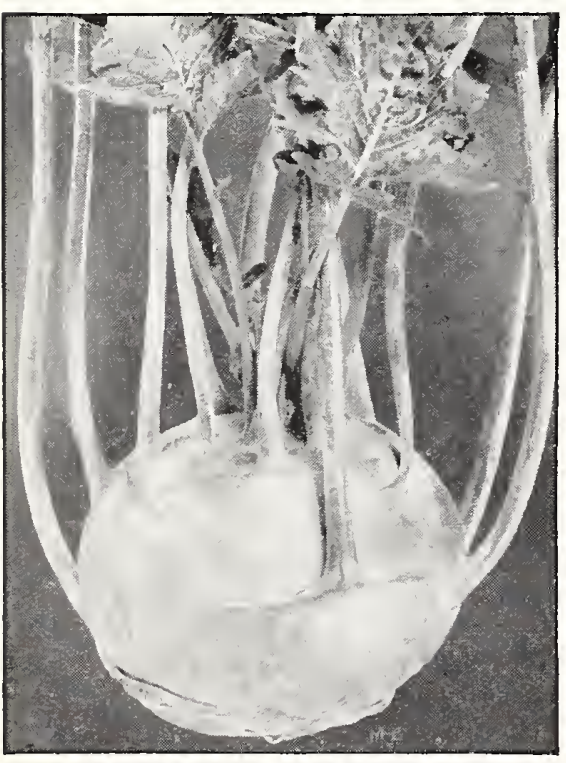

Kohlrabi, Early White Vienna

Brunjes' Long Island Early. Pkt. 5 cts., oz. 20 cts., 1 lb. 60 cts., lb. $\$ 2$.

Brunjes' Long Island Late. Pkt. 5 cts., oz. 20 cts., $\frac{1}{4} l b .60$ cts., lb. $\$ 2$.

\section{Kohlrabi $\stackrel{\text { One oucce will sow }}{\text { eno }}$}

The bulb-like portion of this vegetable is of delicate flavor, especially when small, and cooked similar to white turnips. For early use sow seed outdoors during April and from then on for succession in drills 15 inches apart; later thin out to 6 inches in the row.

Early White Vienna. (Frames.) A short-leaved variety which succeeds well in frames but may also be sown in the open ground. Pkt. 5 ets., oz. 30 ets., $\frac{1}{4} l$ lb. 90. cts., lb. $\$ 3$.

Early White Vienna. Excellent for sowing outside. The leaves grow somewhat larger than the Early White Vienna for frames. Pkt. 5 cts., oz. 30 cts., $\frac{1}{4} l$ b. 90 cts., lb. $\$ 3$.

Early Purple Vienna. Leaves and bulbs are rich purple in color, but the flesh is tender and of fine quality. Pkt. 5 cts., oz. 30 cts., $\frac{1}{4}$ lb. 90 cts., lb. $\$ 3$.

\section{FENNET}

For succession sow from June 15 to July 15 in rows $1 \frac{1}{2}$ to 2 feet apart, and later thin out to 5 inches in the row. Earlier sowings frequently run to seed.

Florence, or Naples. Grows about 2 fect high, forming an oval-shaped bulb just above the ground. Has a peculiar, but very sweet, celery-like taste. Pkt. 5 cts., oz. 20 cts., $1 / 4$ lb. 50 cts., lb. $\$ 1.75$.

\section{GARLIC}

Plant scts every 4 inches in rows 10 inches apart. After the tops turn yellow gather the buibs and store in a dry place like onions. Lb. 60 ets. 


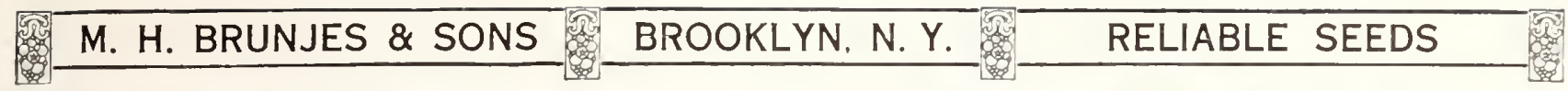

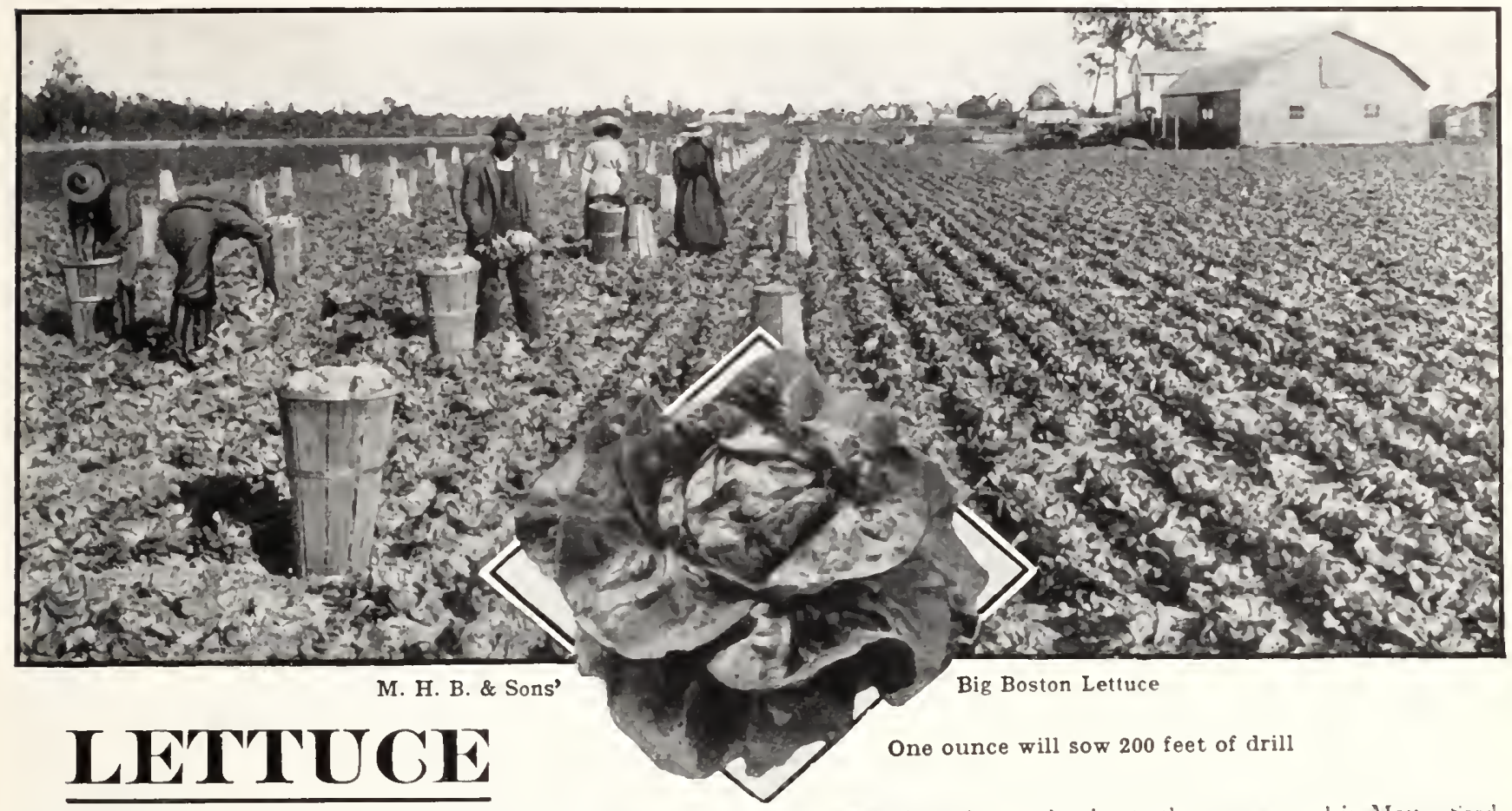

Warly Lettue ma be had lys sowing secel in hotbels during February or March, and transplanting to the open ground in May. Feed is sown outdoors from April to Aurust in drills 12 inches apurt and later thinnerl out to 10 inches in the row. Select a rich, molst soil if possible, as the quality of Lettuce depends largely upon how quickly it

\section{H. B. \& Sons' Big Boston. Thers splendid Letruce hat one of the mo.t} pornlar for early' spring and fall sowing. 'The larre, solid head are light green in color, sighty timer wrth brown. recommend onr stock to be the best pro
10 (cts. oz. 25 (cts., 1 1 1l). $60 \mathrm{cts}, 1 \mathrm{~b}$ ). $\$ 1.75$.

Big Boston, Black-seeded. Quite similar to our white-seeded IBig lioston, but the healls grow somewhat larger. It is most valua-

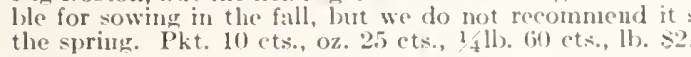

All Seasons. Well allapted for growing in summer for which it is principally used. Globular, well-blanched heads which stand long 81.75 .

Black-seeded Simpson. Tlue plants form a mass of long leaves, of excellent flavor, exceelingly tender and crisp: light green shading almost white. Finc

Boston Market (White-seeded Tennisball). An early, medium-sized Lettuce surted to growing in frames and also for forcing. P'kt. $10 \mathrm{cts.}, 02.25 \mathrm{cts},{ }_{4} 1 \mathrm{l}, 60 \mathrm{cts.}, 1 \mathrm{~b}, 81.75$

Brown Dutch. Well adapted to southern culture, especially in tho fall months, when it may be treated as a winter Lettuce. Pkt. 10 cts., oz. 25 ets., 1 11 ). 60 cts., 1l). 81.75

California Cream Butter. Its soft, thick leaves form large, glolunlar heads of a rich crean-yellow very solid and of street buttery flavor. Pkt. 10 ets., oz. 25 ets., $1-1$ lb. 60 cts., lb. $\$ 1.75$.

Early Curled Simpson. It is not only very early but one Its bright green curly leaves are tender and of a delicate fluvor. Pkt. 10 cts., oz. 25 cts., 1.1h. 60 cts., 11). $\$ 1.75$

Hanson. Succeds in almost any soil and forms large, solid heads somewhat crumpled, at all seasons. Recommended for private gardens. Pkt. 10 cts., oz. 25 ets., ${ }_{4}^{1} 1 \mathrm{~b}$. 60) ets., 11 s. 81.75.

Iceberg. The leaves of this Letuce are beautifully curled at the edges, crisp, brittle and bright green; very solid; well blanched. Pkt. 10 cts., oz. 25 cts., 1/4 lb. 60 cts., lb. 82.

Wayahead. Highly recommended for sowing early in coldframes or outdoors in spring, summer or early fall. It grows rapidly, being
one of the earliest Lettuces in our list, while the heads are solid and of the finest quality. Be sure to try it. Pkt. 10 ets., oz. 25 cts., $1 / 4$ th. 60 cts., 1b. 81.75 .
Mammoth Black-seeded Butter. Our customers shonlul

brown; quality unsurpassed, being temrler,

Market-Gardeners' Private Stock. An cxcellent summer Lettuce, the heart of which is well blanched, very tender and crisp.

May King. One of the lendirng varieties for forcing or early outdoor planting. It is of very quick growth, of particularly fine flavor and size light golden yellow, and are very crivi
25 ets., ${ }_{4} 1 \mathrm{lb}$. 60 cts., $1 \mathrm{~b}$. S1.75.

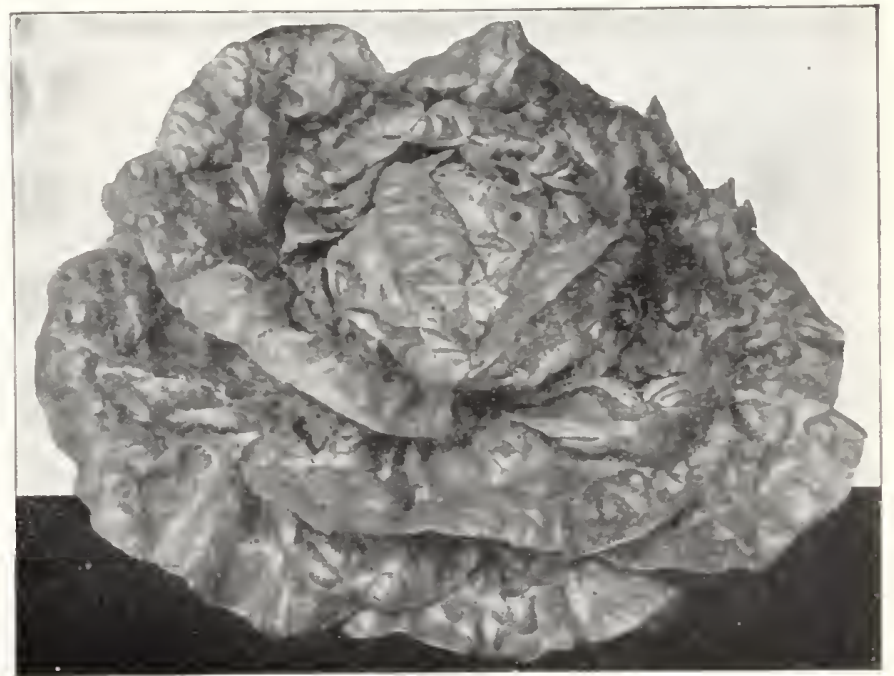

Lettuce, Mammoth Black-seeded Butter 


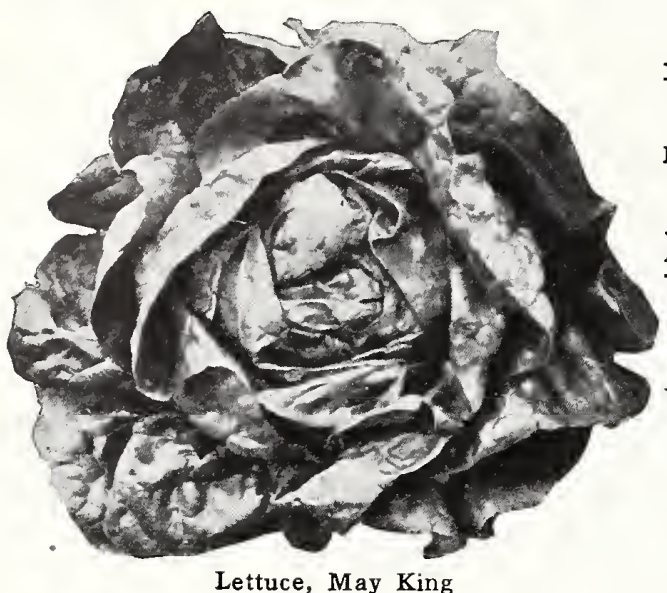

Lettuce, May King

\section{ROMAINE, Or COS LETTUGE}

\section{H. B. \& Sons' Mammoth White Cos. Forms very}

heads, well rounded at the top; light green in color and of excellent quality. Although it is not quite as early as the Paris White Cos variety the heads are considerably larger. Pkt. 10 cts., oz. 25 cts., $\frac{1}{4}$ b. 75 cts., lb. $\$ 2.50$.

Paris White Cos. This variety is becoming more popular every year. The outer leavcs are dark green, while the inner ones closely overlap each other, forming a handsome, well-blanched head of creamy white. Distinguished fron the American cabbagehead type of Lettuce by its long narrow leaves, forming oblong shaped heads. Pkt. 10 cts., oz. 25 cts., $\frac{1}{4} \mathrm{lb} .75$ cts., 1 b. $\$ 2.50$.

For succession sow: spring, Mammoth Black-seeded Butter; summer, M. H. B. \& Sons' Salamander; fall, M. H. B. \& Sons' Big Boston.

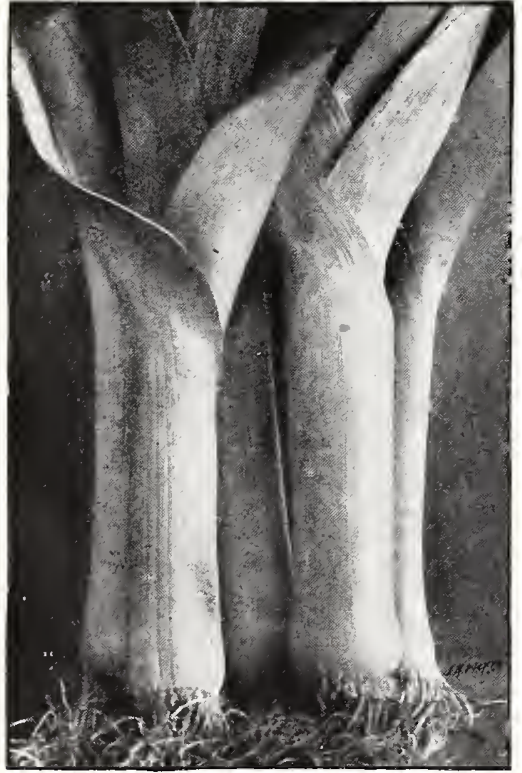

Leek, Large American Flag

New York, or Wonderful. The broad, dark green leaves are beautifully curled and fringed at the edges, while the heads are large, solid and very tender. Pkt: $10 \mathrm{cts}$., oz. 25 cts., $1 / 4$ lb. 60 ets., lb. $\$ 2$.

Prizehead. For those who prefer a leaf Lettuce, Prizehead will be found a most reliable variety. Leaves large and spreading, somewhat ruffled and exceptionally tender. Easily grown. Pkt. 10 cts., oz. 25 cts., $1 / 4$ lb. 60 cts., 1b. $\$ 1.75$.

M. H. B. \& Sons' Salamander. A superb Lettuce and undoubtedly the are well formed, compact, licht most popular of all summer sorts. Heads of the most satisfactory lettuces for in color and unowing outdoors and highly oz. 25 cts., $1 / 4$ lb. 60 cts., lb. $\$ 1.75$.

Unrivaled. Similar in almost every way to Big Boston, except that the color is solid green without any tinge of brown whatever. Pkt. $10 \mathrm{cts}$. 0 o. $25 \mathrm{cts}$., $1 / 4 \mathrm{lb}$. $60 \mathrm{cts}$. lb. $\$ 2$.

\section{LETTUGE PLANTS. See page 28}

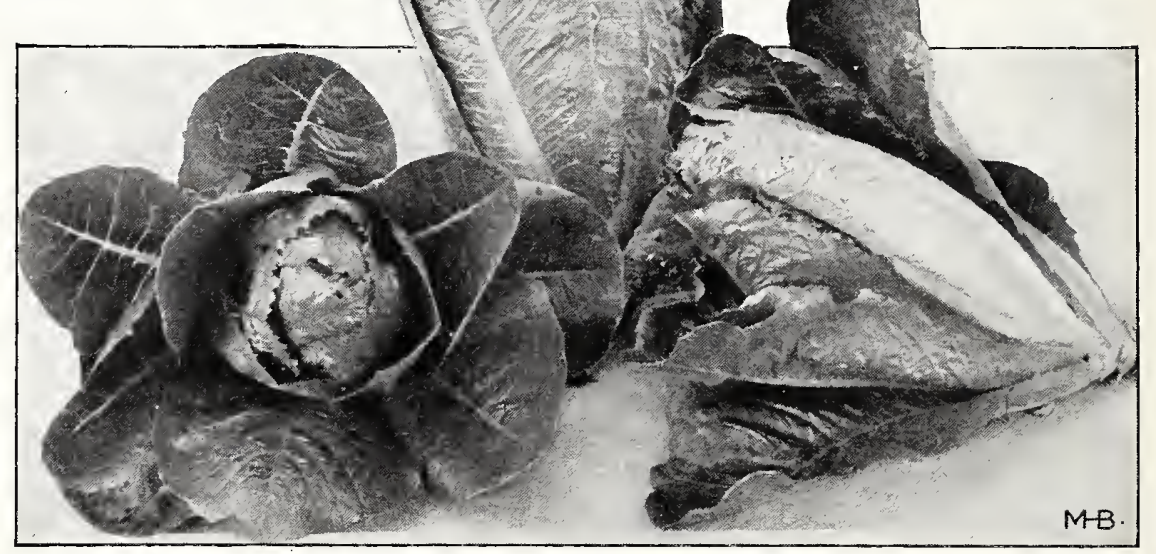

\section{ICEK One ounce will sow}

Onc of the three vegetables principally used for flavoring soup. Both for summer and winter usc sow seed during April and May in drills $\frac{1}{2}$ inch decp, and when quite strong, usually the early part of July, transplant in rows 12 inches apart and 5 inches apart in the row. Plants should be slightly trimmed before setting out.

Large American Flag. The best variety for the home garden. Early, very large, and withstands considerable cold weather, though it is mostly grown for summer and early fall. Pkt. 5 cts., oz. 20 cts., $\frac{1}{4}$ lb. 60 cts., lb. $\$ 2.25$.

Brunjes' Winter. Can be left to stand outdoors during the winter and will remain in fine condition until the following spring. Very solid and firm, but not quite so large as the preceding. Pkt. 5 cts., oz. 25 cts., $\frac{1}{4}$ lb. 75 cts., lb. $\$ 2.50$.

\section{MUSTARD One ounce will sow 75 feet of drill}

The leaves impart a sharp, pungent flavor to salads and are also highly esteemed when cooked like spinach. For a succession, sow seed $\frac{1}{2}$ inch deep, in drills 8 inches apart, every few weeks from early spring until September.

White English. The best for salad; grows rapidly. Pkt. 5 cts., oz. 10 cts., $\frac{1}{4} 1$ b. 25 cts., lb. 75 cts.

\section{NASTUR'TIUM One ounce will sow 20 feet of drill}

Although the Nasturtium is grown principally for its flowers, the green seeds when pickled may be used as a substitute for capers. Sow the seed 1 inch decp, usually about the beginning of May.

Tall Mixed. Requires the support of a trellis or fence. Pkt. 5 cts., oz. 15 cts., $\frac{1}{4} \mathrm{lb} .50$ cts., lb. $\$ 1.50$.
Dwaxf Mixed. Pkt. 5 cts., oz. 15 cts., $\frac{1}{4}$ lb. 50 cts., lb. $\$ 1.50$. 


\section{H. BRUNJES \& SONS \\ MUSKMELON}

BROOKLYN, N. Y.

One ounce will plant 60 hills

A light, rich soil is preferred for growing Melons. In May, when the soil has become warm and dry, plant is to 10 seeds $\frac{1}{2}$ incll deep in hills 5 to 6 feet apart each way. Before planting add a cquant ity of well-rotted manure to each hill and mix thoronghly. Like cucumber: and squash, the young plants should be protected from inseets and for this purpose a dusting of tobacco dust is advisable. As soon as the plants begin crowding and after the dinger from inserets is past remove all but 3 plants to a lill. The side runners should be pinched back to insure fruiting. Spray at intervals witl Bordeanx Mixture, to which a small quantity of arsenate of bad has been added.

Rocky Ford. One of the funcst basket Melons in eultivation, vigorous and ontinuous bearers: oval fruit having thick. Frees flesh of exellent quality. Splendid either for the private gardener or shipuer. I'kt. 5 cts., oz. 15) ('ts., ${ }_{4}^{1} \mathrm{lb} .10 \mathrm{cts} ., 1 \mathrm{l}$ ). $\$ 1.25$.

Gold-lined Rocky Ford. We feel sure our customers will be pleased with Gold-lined Rocky" Ford. It is slightly" oval in shape, no ribs. and hearily netted over the antire melon. The flesh is thick finegrained and deliciously swect: color green with a gold margin next to the seed-cavity. Pkt. 5 ets., $02.20 \mathrm{cts.}, 31 \mathrm{~b}, 60 \mathrm{cts} ., 1 \mathrm{~b}, \$ 2$.

Burrell's Gem. An ideal variety for the garden and especially desirable for shipping. Mredium size, averaging 2 to $2 x_{4}$ pounds each oval in shape, with thin, hard rind and dark green, closely netted skin. The unusually thick, salmon-red flesh is fine-grained and possesses a rich, spiey flaror. Plkt. 5 cts., oz. 15 cts., $11 \mathrm{~b} .40$ cts. lb. $\$ 1.25$.

Emerald Gem. A favorite early sort of the finest quality. The green, while the flesh, of salmon color, ripens almost to the rind and is the sweetest of any. 1'kt. 5 ets., oz. 15 ets., $11 \mathrm{~b}, 40 \mathrm{ets.,} \mathrm{lb.}$ $\$ 1.25$.

Extra-early Hackensack. This is a popular-green-fleshed variety with larke, heavily neted fruit. Good for bhipping. Pkt, 5 ets. oz. 15 ets., 'llb. 40 ets., lb. $\$ 1.25$.

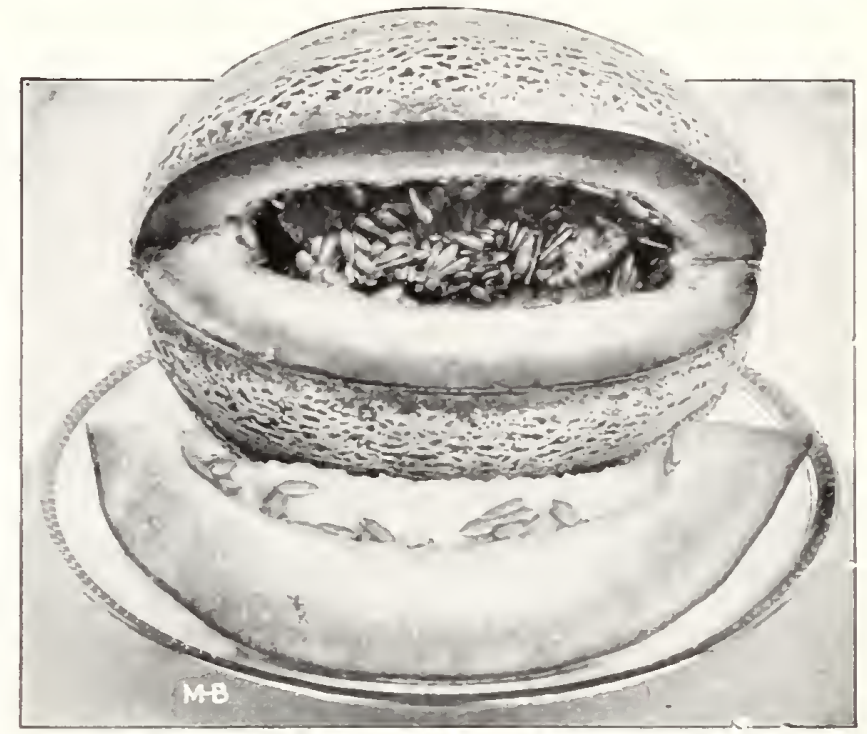

Muskmelon, Rocky Ford

Hoodoo. This grand new. Melon is highly recommented either for the home table or for thipping. It is uniform in size, nearly round, heavily netted, while the flesh is very thick, exceedingly swect, and rich or

Honey Dew. I new troes of Mhakinclon with oroid slaped fruit about 10 inches long and sinches in dianeter. The shin is hard and smooth, creamy vellow in color and the thick flesh of light emerald green is unisually sweet and melting. Pht. 10 cts., oz. $25 \mathrm{cts}$., ?lb. $75 \mathrm{cts} .1 \mathrm{l}$. $\$ 2.50$.

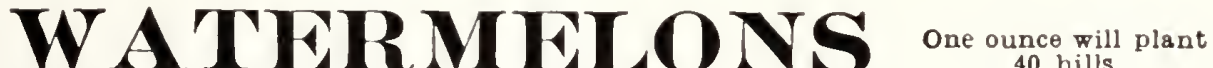

Culture similar to that of muskmelon, excepting the hills should be Alabama Sweet. Popular among the southern growers, Long and
very large with dark green rind and bripht red flesh of exeellent very large, with dark green rind and bright red flesh
quality. Pkt. 5 cts., oz. 10 cts., Alb. 30 cts. 1 b. 90 ets.

Harris' Earliest. An early, oval-shaped yariety with delieiously

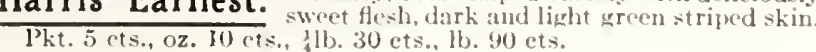

Kolb's Gem. Very large, and owing to its hard, firm rinel it is used extensively" for shipping. P'kt. 5) ets.. oz. $10 \mathrm{cts}, \frac{2}{8} \mathrm{lb} .30 \mathrm{cts}, \mathrm{lb} .90 \mathrm{c}$.

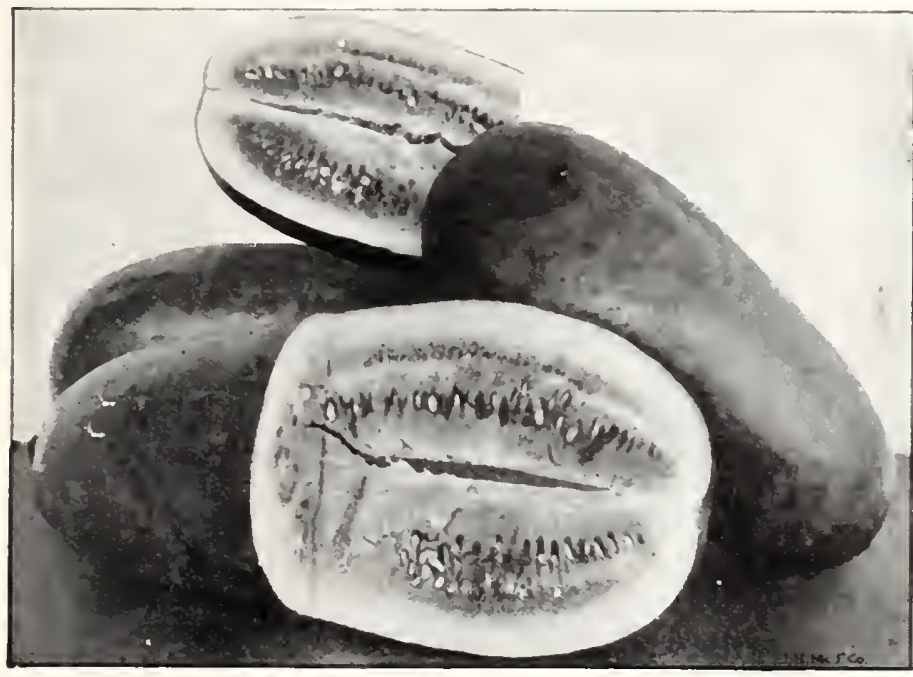

Watermelon, Kleckley Sweets
Kleckley Sweets. Medium to large size, oval in form, and ut. ceptionally fine for the private garden. Pkt, $5 \mathrm{cts}, \mathrm{oz}, 10 \mathrm{cts}$.

Sweetheart. The fruit is light green strimed darker, oval and Wweetheart. uniform in shape, having rich red flesh of delicious, Citron, Red-seeded. Round and smooth; fles white, used only for preserving. Pkt. 5 cts., oz. 10 ets., allb. 30 ets., lb. 90 ets.

\section{Mushroom Spawn}

Ten pounds will spawn 10 feet square

To grow M I ushrooms does not necessarily require an special house, as a cellar, shed, or exen under ureenhouse benches will answer the purpose. Of course, conditions must be such that an even temperature of 50 to 65 degrees ean be maintained. Secure some fresh horse manure, not too coarse, and also at quantity of good, rich soil. To 1 part of soil add 2 or 3 of manure, and when thoroughly mixed. form into beds 3 feet wide, and from 10 to 12 inches deep, pounding it together as you proceed. The bed will soon become very hot and not until temperature recedes to 80 or 90 degrees is it ready tor the spawn. Make holes s to 10 inches apart and large enowgh to admit the spawn, which is to be broken into pieces the size of a hen's egg and covered $1 \frac{1}{2}$ inches. After remaining in this condition from s to 10 dars, eover the bed with 2 inches of fresh soil and after firming with the back of a spade cover with 4 inches of salt hay or straw. It takes about 2 months before the first Mushrooms appear. When watering, the water should be about 95 degrees.

American Pure.Culture. (In bricks.) Per brick, 35 cts.; 12 bricks. $\$ 4$.

By mail, add postage at zone rates. One brick weighs $11 / 2 \mathrm{lbs}$. 
A rich loamy soil, preferably one that lias been liberally manurcd the previous scason, is best suited to growing Onions. Just as soon as the soil is in workable condition, usually in April, sow seed 1/2inch deep in drills 12 inches apart, and later thin out the plants to 4 inches apart in the row. Hoe frequently and also give occasional wecding. Our Onion secd is raised from selected bulbs and no better stock can be obtained at any price.

\section{Three of the Finest Onions}

Southport White Globe. Owing to its beautiful white skin, pearance, it has become a favorite with all. A good keeper and abundant yiclder, with firm, mild flesh. Pkt. 10 cts., oz. 30 ets., $1 / 4$ lb. $\$ 1,1 \mathrm{lb} . \$ 3.50$.

Southport Red Globe. A medium-early varicty with large very small neck and deep, purplish red color; flesh tender and of excellent quality. Extensively grown both for market and private use. Pkt. 10 cts., oz. 25 cts., $1_{4}$ Ib. 75 cts., lb. $\$ 2.50$.

Southport Yellow Globe. Large Onion of globular form, color. It matures about the same time as Southport Red Globe and has flesh of the same high quality. Excellent keeper. Pkt. 10 cts., oz. 25 cts., $1 / 41$ lb. 75 cts., lb. $\$ 2.50$.

Adriatic Barletta. The small, round, snow-white bulbs mature very early and are prized for pickling. Pkt. $10 \mathrm{cts}$, oz. $25 \mathrm{cts}$. $1 / 4$ lb. 75 ets., lb. $\$ 2.50$.

Ailsa Craig. An exceptionally large Onion and one of the finest for exhibiting. It is oval-shaped, slightly pointed at each end, with pale, straw-colored skin and solid white flesh. To obtain extra-large specimens, sow seed in hotbeds during February and transplant to the open ground in April. Pkt. 10 cts., oz. 30 ets., $1 / 4$ lb. 90 cts., lb. $\$ 3$.

Hardy White Winter. The seed should be sown during the latter part of August, or beginning of September, and the plants left standing over winter. In this way pure white, flat-shaped Onions of medium size may be had from three to four weeks earlicr than seed sown in spring. Pkt. 10 ets., oz. 30 cts., 1/4l lb. 90 cts., lb. $\$ 3$.

Large Red Wethersfield. Splendid deep red sort and fine kccper. Grows to a large size, of rather sharp flavor. in-crop varieties and grows best in rich, dry soil. Pkt. 10 cts., oz. 25 cts., 1 ĺlb. 75 cts., lb. $\$ 2.50$.

Prizetaker. A very popular variety of enormous size, single bulbs often weighing from two to four pounds. Handsome, globularformed Onions with bright yellow skin and fine-grained flesh of the purest white. An immense cropper. Pkt. $10 \mathrm{cts}$., oz. 25 cts., 1/4lb. 75 cts., lb. $\$ 2.50$.

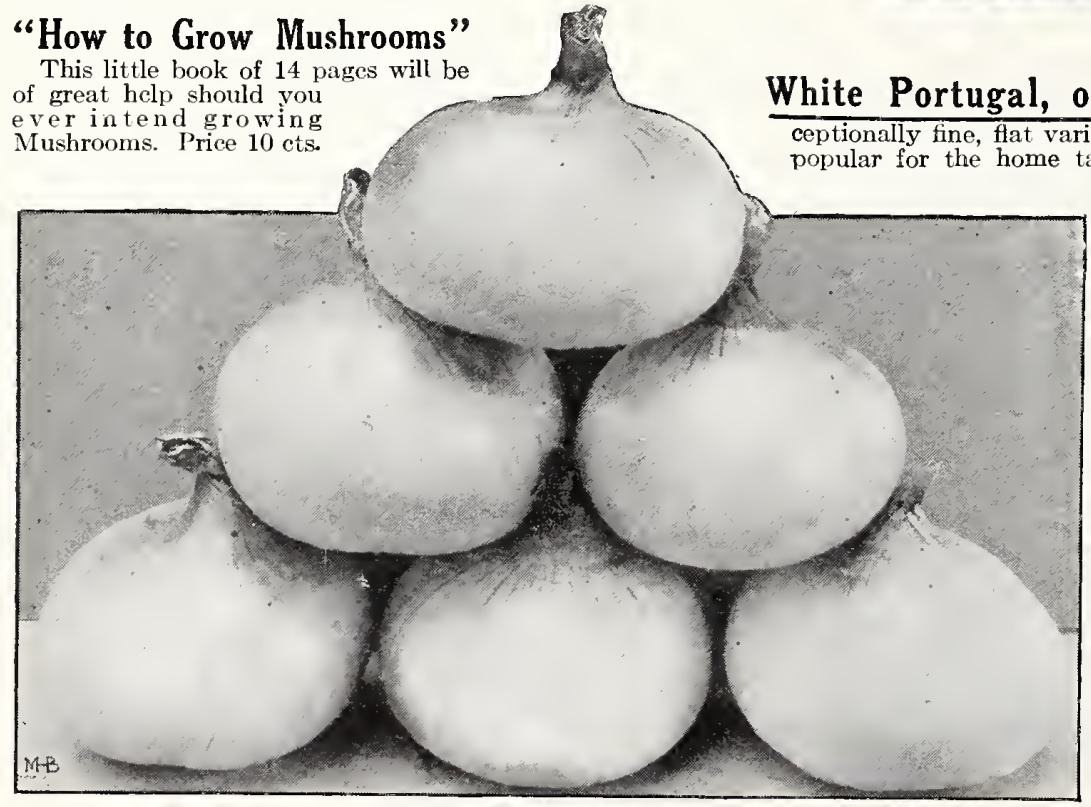

Onion, White Portugal
This little book of 14 pages will be of great help should you

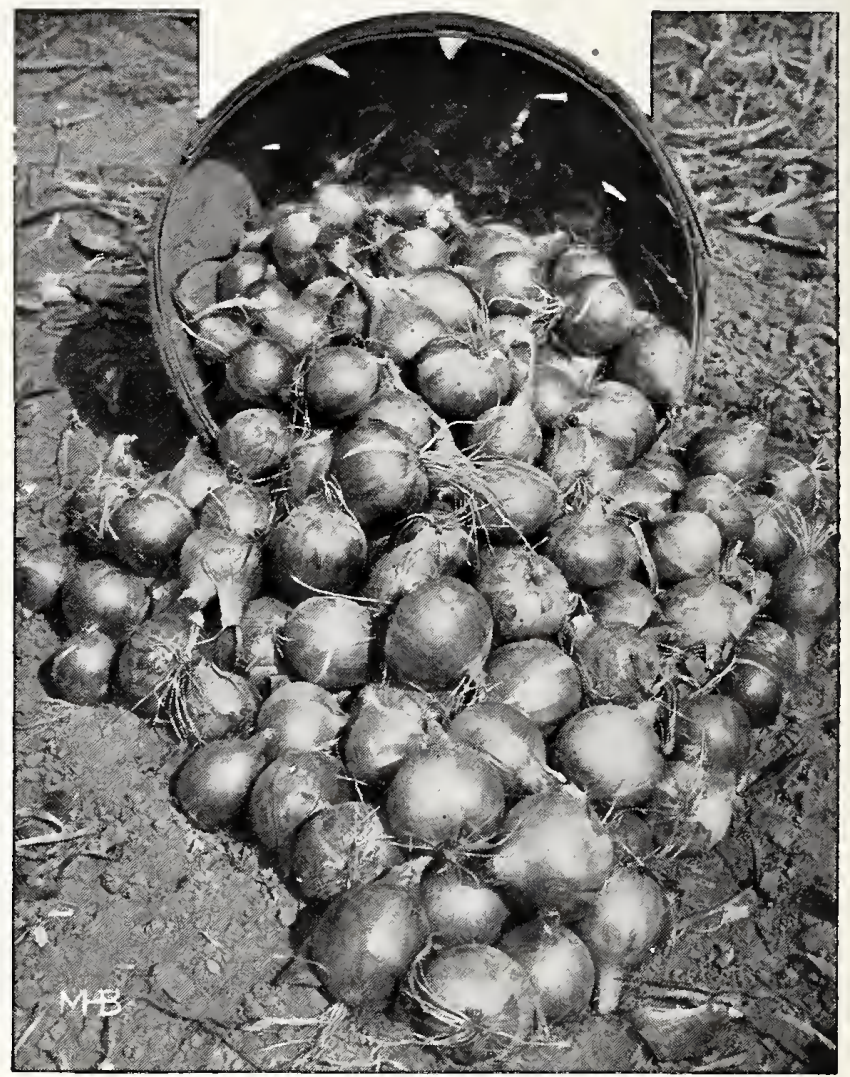

Onion, Yellow Globe Danvers
American Silverskin. Market-gardeners find this an exceptionally fine, flat varicty of good size and the purest white, but it is also A good keeper with swcet, mild flesh. Pkt. 10 cts., oz. 30 cts., $1 / 4$ lb. 90 cts., lb. $\$ 3$.

White Oueen. One of the best early varieWhite Queen. ties for the garden. Tho bulbs, which are ready for use about the same time as Adriatic Barletta, are of the purest white, almost round and measure from 1 to 2 inches in diameter. It is especially desirable for pickling and looks very attractive when bunched for the market. Pkt. $10 \mathrm{cts}$., oz. $25 \mathrm{c}$., $1 / 4$ lb. $75 \mathrm{cts}, \mathrm{lb} . \$ 2.50$.

White Scullion. Similar in growth to the Leek, growing straight and not forming any bulb. Sow the seed during August and they will bu ready for the table in early spring. Used only in the green state. Pkt. 10 cts., oz. 25 cts., $1 / 4$ lb. 75 ets., lb. $\$ 2.50$.

Yellow Globe Danvers. Especially recone of the best yellow sort many who will have no other. In shape it is nearly round with light brown-colored skin and solid white flesh. It is a heavy cropper, noted for its superior keeping qualities, and is extensively grown by both market and private gardencrs for winter storing. Pkt. $10 \mathrm{cts}$, oz. 25 cts., $1 / 4$ lb. 75 cts., lb. $\$ 2.50$. 


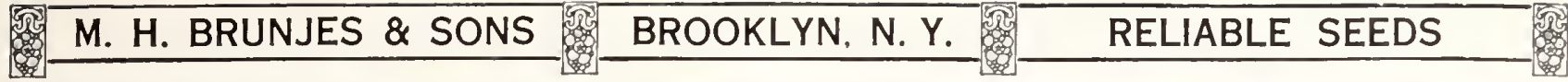

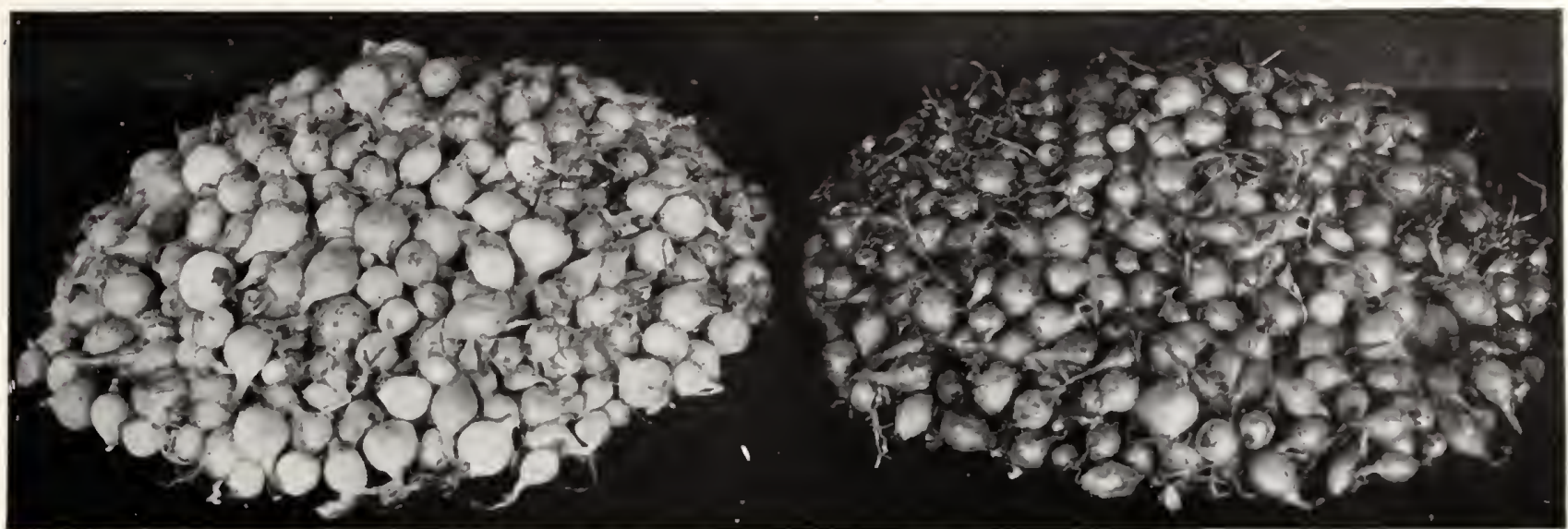

White Onion Sets

Yellow Onion Sets

\section{ONION SE'TS}

By planting sets, Onions may be lrad much earlier than from spring-sown seed. To obtain large Onions sets should be planted 3 to 4 inches apart, in rows 1 foot apart, as soon as the frost is out of the ground.

If by parcel post, add postage at zone rate. $1 \mathrm{gt}$. weighs $11 / 4 \mathrm{lbs}$.

White Sets.

Red Sets

Yellow Sets...................... 30 $100 \quad 150$ Qt. 30 spk. Pk.

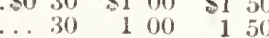

Egyptian, or Top Onion. Produces small bullos ou top of stalks, which are planted in antumn and used in the sprime as scullions. Ready in August. Qt. $25 \mathrm{cts.}, \frac{1}{3} p k .90 \mathrm{cts.,} \mathrm{pk.} \$ 1.60$.

\section{OKRA, or GUMBO}

\section{One ounce will sow 40 feet of drill}

Extensively grown in the South. The areen pods are used in soups. Sow during May in drills 3 feet apart, and later thin out to 10 inehes in the row.

White Velvet. Pods are round, smooth, white and tender. Pkt. 5 cts., oz. 10 cts., 1 b. 20 cts., lb. 65 cts.

Perkins Mammoth Long Pod. Wonderfully productive: immense, deep green pods, slim but retaining their tenderness longer than mest sorts. Pkt. 5 cts., oz. 10 ets., ?̂lb. 20 cts., lb. 65 ets.

\section{PRICES ON SEED POTATOES}

We shall be pleased to quote our lowest prices on the varieties of Seed Potatoes we have listed

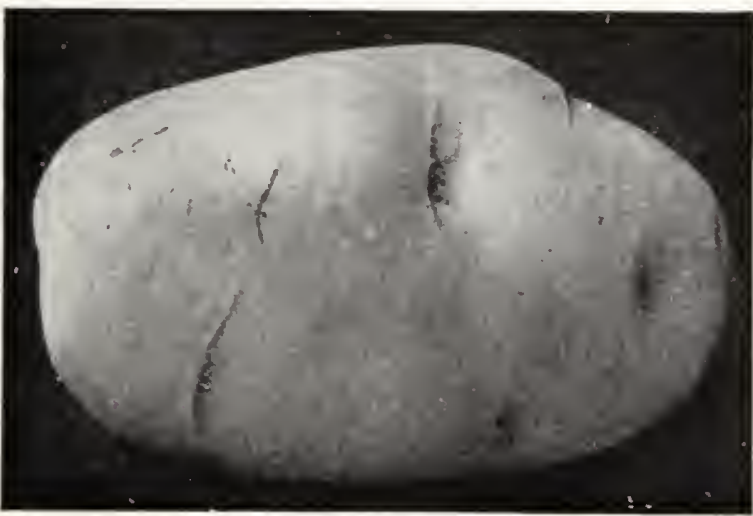

Potato, Green Mountain

\section{SEED POTATOES}

Ten bushels cut tubers will plant one acre; one peck will plant 125 hills

\section{Ghoice Maine-Grown Stock}

Our seed Potatoes are especially grown for sced purposes and ean be depended upon for best results. Planting may commence as early in the spring at the ground can be morked. Place one piece every 12 inches in rows 21 feet apart, covering abont 4 inclees. When eutting the seed, eare should be taken to allow at least one good eye, or two small ones, to eacli piece. A spraying of Paris green or arseliate of lead prevents the ravages of the potato bug.

Important. Potatoes may le sent by express or freight, according to quantity, at purchaser's expense. (lur sacks contain 165 pounds.

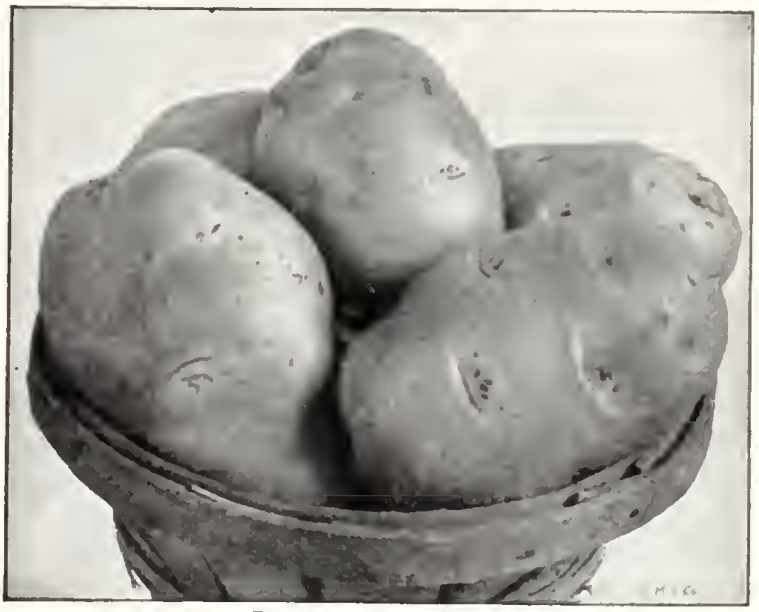

Potatoes, Early Rose

Early Rose. Although one of the older varicties, this well-known yose. and very popular Potato is still among the most largely planted for the home garden. It matures early, is a good cropper and one of the best in quality.

Green Mountain. This variets is most extensively grown on of all late Potatoes. It is an immense cropper, wonderful keeper, and one of the funest cooking varieties.

Irish Cobbler. Equally popular both with market-gardeners not onlyone of the and also for planting in the home-garden. It is duce a good vield of ten from 300 to 350 bushels to the acre. A large, handsome Potato of uniform shaje; flos white and of fine flavor. A profitable variety to plant. 


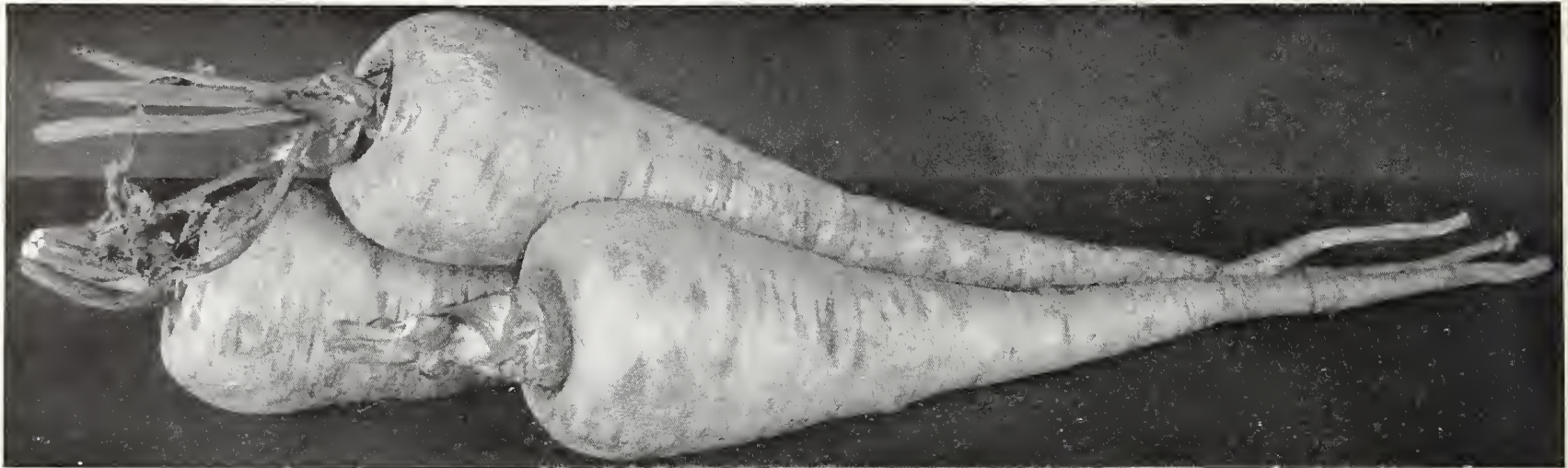

Parsnip, M. H. B. \& Sons' Hollow Crown

\section{Parsmip $\begin{gathered}\text { One ounce will sow } \\ 200 \text { feet of drill }\end{gathered}$}

Parsnips require a deep, rich, mellow soil, and should be sown in drills $1 \frac{1}{2}$ feet apart and $\frac{1}{2}$ inch deep as soon as the ground can be worked in spring. Thin plants to 6 inches apart in the row and cultivate frequently. Like Brussels sprouts and kale, their flavor is improved after a hard frost.

M. H. B. \& Sons' Hollow Crown. There is no finer Parsnip grown than the true Hollow Crown immense cropper. We have a very choice stock of this variety. Pkt. 5 cts., oz. 10 cts., $1 / 4 \mathrm{Lb}$. $30 \mathrm{cts}$., $1 \mathrm{D} . \$ 1$.

\section{Parsley}

As the seed is slow in germinating, it should be sown as early in spring as possible in drills 1 foot apart and $\frac{1}{2}$ inch deep. When the plants are well advanced thin out to 6 inches apart in the row. By making a second sowing, under glass, in July or August, a supply can he had throughout the winter.

Extra Double Curled. Tnis is an exceptionally fine strain of double curled Parsley, and one that may be depended upon for

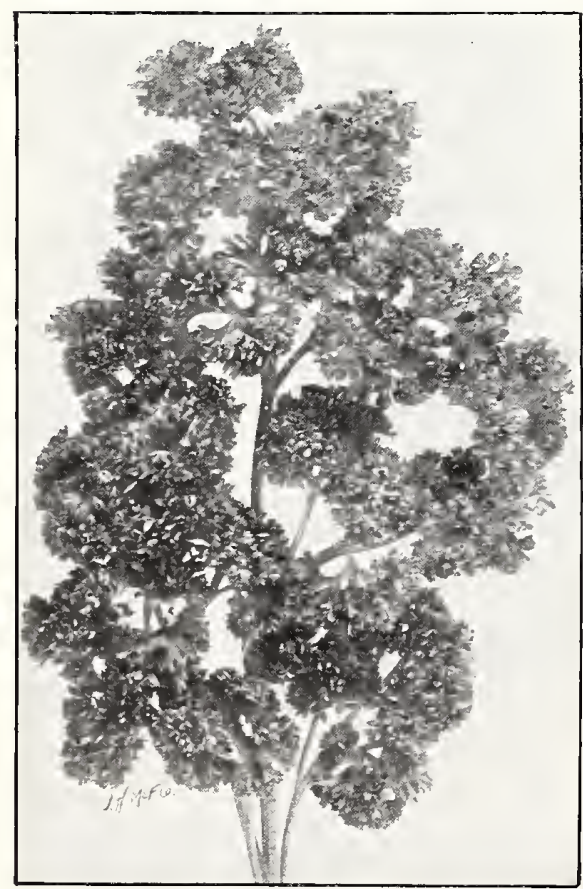

Parsley, Extra Double Curled appearance, deeply curled, very dark green in color and unequaled for flavoring and garnishing. It withstands the extreme heat and drought of summer better than most varieties and it has also proved to be the best variety for fall or winter use. Pkt. 5c., oz. 15c., 1 lb. 40c., lb. $\$ 1.25$.

Champion Moss Curled. A fine, curly variety, resembling the above in appearance, but of more rapid growth. Pkt. 5 cts., oz. 15c., $\frac{x}{4}$ lb. 40 cts., lb. $\$ 1.25$.

Plain. Leaves are not curled, and have an excellent flavor preferred by many. Pkt. 5 cts., oz. 15 cts., $\frac{1}{4} \mathrm{lb} .40$ cts., lb. $\$ 1.25$.

Turnip - rooted, or Hamb urg. The roots, which resemble small Parsnips, are valuable for flavoring soups, while the leaves, similar to those of celery, may also be used for the same purpose. The roots may be dug in the fall and stored in the cellar, or they may be left standing outdoors through the winter for use in early spring. Pkt. 5 cts., oz. 15 cts., $\frac{1}{4}$ lb. $40 \mathrm{cts}$., lb. $\$ 1.25$.

\section{PEPPER PLANTS}

\section{PeD PeI One ounce will produce}

Peppers should be started in a hotbed during March or April. The latter part of May transplant to the oper ground in rows 2 feet apart and 18 inches in the row.

Chinese Giant. An unusually large sweet Pepper, Nose, but a little later in maturing. The flesh is quite thick, very mild and of a bright red color. Plants 2 feet high and very productive. Pkt. $10 \mathrm{cts}$., oz. $50 \mathrm{cts} ., 1 / 4 \mathrm{lb}$. $\$ 1.60, \mathrm{lb}$. $\$ 6$.

Large Bell, or Bull Nose. Plant of vigorous large thick Peppers of mild flavor. Pkt. 10 ets., oz. 35 cts., 1/16. $\$ 1.15$, lb. $\$ 4$.

Giant Crimson. The earliest and most productive of the very large Peppers. Fruit of immense size, thick fleshed, mild and very sweet. Pkt. 10 cts., oz. 50 cts., $1 / 1$ lb. $\$ 1.60$, lb. $\$ 6$.

California Wonder. A very desirable new varicty with dark green fruits $41 / 2$ inches long and 4 inches across. Flesh unusually thick and sweet. Pkt. 10 cts., $1 / 20 z .45$ cts., oz. 85 cts., 1/1b. $\$ 2.75$, lb. $\$ 10$.

Long Red Cayenne. The bright scarlet pods, varying from 3 to 4 inches in length, are very pungent. Pkt. 10 cts., oz. 35 ets., $1 / 4$ lb. $\$ 1.15$, lb. $\$ 4$.

Chili. A late-maturing variety with small red fruit, which is used extensively for pepper sauce. Pkt. 10 ets., oz. 35 cts., $1 / 41$ b. $\$ 1.15,1 b . \$ 4$.

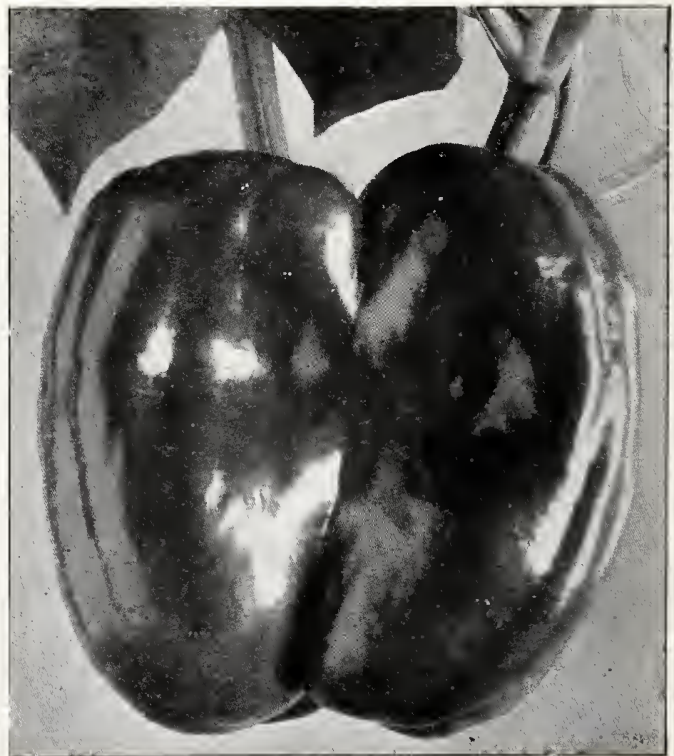

Pepper, Chinese Giant 


\section{PEAS}

One pound will plant about 100 feet of drill

All smooth-seeded Peas may be planted as early in spring as the soil can be prepared for them. They are very hardy, and will endure a low temperature, both before and after sprouting. By sowing for the first crop as early as practicable, and for succesion at intervals of about two weeks until the first of June, a good supply of this delicious vegetable may be enjoyed through the greater part of the sunmer. Late sowings, however, do not yield so well as early ones, beeause the hot and dry weather is unfavorable to the development of the plants. The seed should be sown in drills about 3 inches deep and from 3 to 4 feet apart, according to the variety, taller sorts requiring more room than the dwarf ones. Dwarf Peas require a very rich soil, while tall ones thrive best in rather thin ground, which does not stimulate too lixuriant growth in the vines, to the detrinent of the pods. The latter are frequently sown in double rows, with the brush or support of some kind between them. Wrinkled Peas are not so hardy as the smooth sorts, and should not be sown so early, but are superior to them in quality, more delieate in flaror, and remain longer in season.

IF BY PARCEL POST, ADD POSTAGE AT ZONE RATES

\section{EXTRA-EARLY}

First of All. An extremely early variety of vigorous growth, usually attaining a height of $2 \frac{1}{2}$ feet and bearing small-podded Peas of fair quality. $\frac{1}{2}$ lb. 20 ets., lb. 35 cts., 2 lbs. 65 cts., 10 lbs. $\$ 2.75$.

Little Marvel. This is without doubt the finest of the extra- early varieties. The plants are of dwarf habit, not excceding 1s inehes, immensely productive, bearing pods of good size and dark green eolor which contain six or seven Peas of excellent flavor. A gem for the home-garden and a profitable variety for the market-gardener. $\frac{1}{2} \mathrm{lb}, 20$ ets., lb. 35 ets., 2 lbs. 65 ets., $10 \mathrm{lbs}$. $\$ 2.75$

Nott's Excelsior. One of the best dwarf, early, wrinkled Peas. tive and the pods, 3 inches long, generally contain six or seven large, sweet Peas of the finest quality. Well recommended for home use. $\frac{1}{2} \mathrm{lb} .20 \mathrm{cts}$., lb. $35 \mathrm{cts.}, 2 \mathrm{lbs} .65 \mathrm{ets}, 10 \mathrm{lbs} .52 .75$.

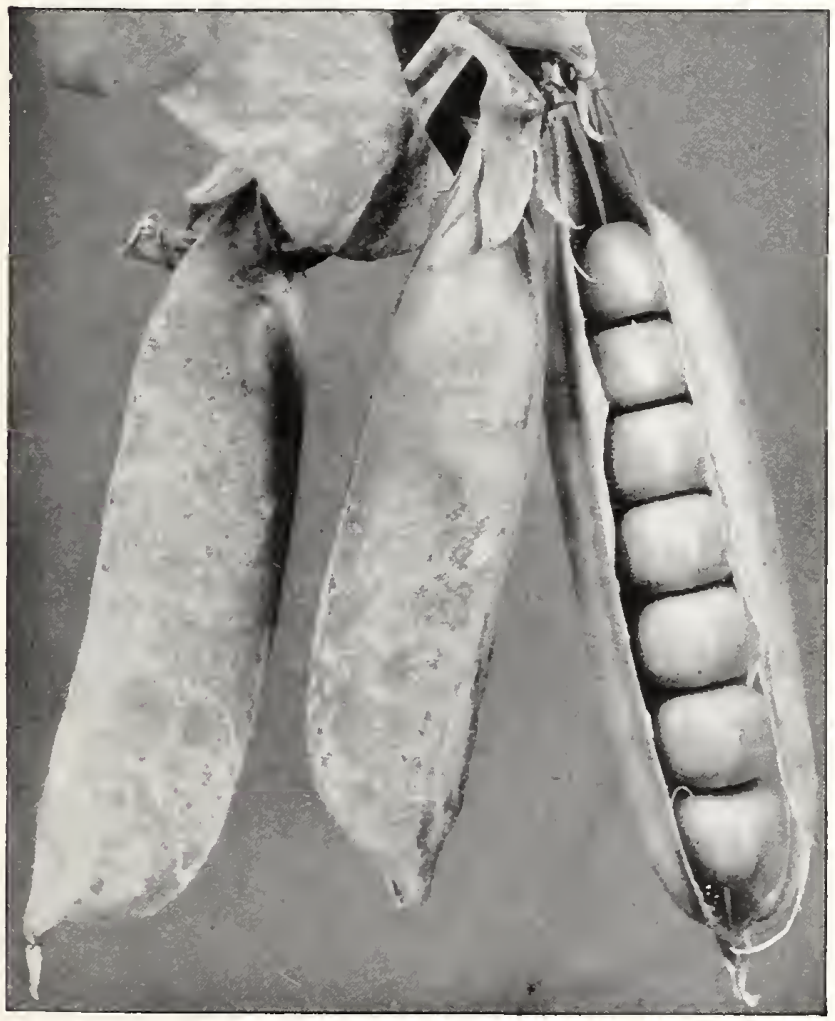

Peas, Nott's Excelsior

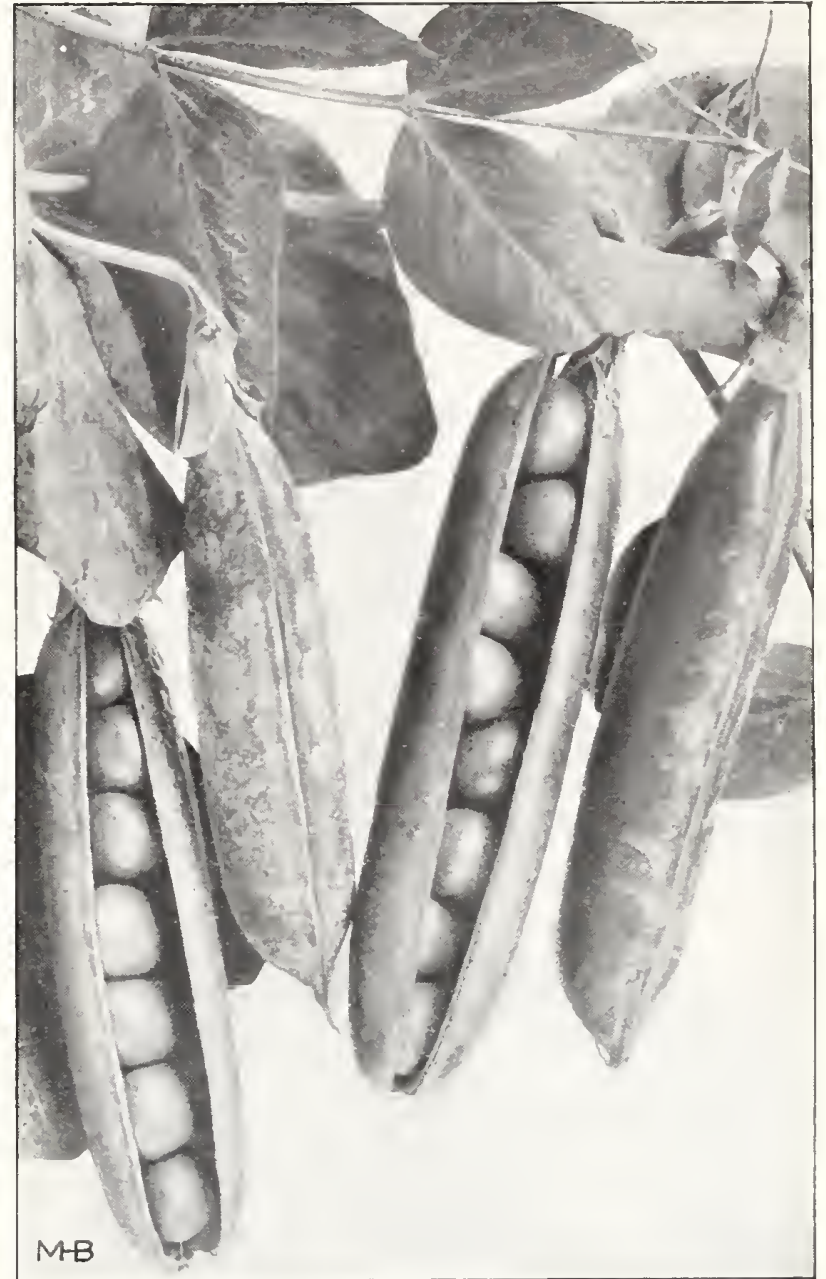

Peas, Gradus

Premium Gem. The round pods, $2 \frac{1}{2}$ inches long, are borne on short bushes, which are well suited to small gardens. $\frac{1}{2} l \mathrm{~b} .20 \mathrm{cts}$. lb. 35 cts.. 2 lbs. 65 cts., 10 lbs. $\$ 2.75$.

American Wonder. Dwarfer and a trifle earlier than the preceding but not quite so productive. The Peas are sweet, tender and of delicious flavor. $\frac{1}{2} 1 \mathrm{~b} .20 \mathrm{cts} ., \mathrm{lb} .35 \mathrm{cts}, 2$ lbs. $65 \mathrm{cts}$., $10 \mathrm{lbs}$. $\$ 2.75$.

Sutton's Excelsior. This Pea is a great improvement over the other dwarf early varieties. It is a very heary cropler and the large, handsome pods, uniform in size, are well filled with immense Peas of unsurpassed quality. Height 15 inches. $\frac{1}{2} \mathrm{lb} .20$ ets., lb. 35 ets., 2 lbs. 65 cts., 10 lbs. $\$ 2.75$.

Gradus. One of the most popular wrinkled sorts. Even though it Gradus. matures a short time later than the extra-earlies, the pods, fully as long as those of the well-known Telephone, contain very large Peas that are unexcelled for sweetness. A superior variety for the market or private garden. $\frac{1}{2} l \mathrm{~b} .20 \mathrm{cts} ., 1 \mathrm{~b} .35 \mathrm{cts}$., $2 \mathrm{lbs} .70$ ets., $10 \mathrm{lbs} . \$ 3,25$.

Thomas Laxton. Another exceedingly fine wrinkled variety which moar square at the ends, large size, deep green in color and of the finest flavor. Although the pods do not ripen quite so early as those of the Gradus, the vines are a little more productive. Height 3 feet $\frac{1}{2}$ lb. 20 ets., lb. 35 ets., 2 lbs, 70 ets., $10 \mathrm{lbs}, \$ 3.25$. Laxtonian. This new wrinkled Pea is very much like the wellonly about 15 inehes high. It matures somewhat earlier than Gradus, is equally sweet, and is sure to become one of the leading early Peas for the garden. $\frac{1}{2} \mathrm{lb}, 20$ ets., lb. 35 cts., 2 lbs. 70 ets.. $10 \mathrm{lbs} . \$ 3.25$.

NOTE.-One pound of Peas is a little more than a pint 


\section{H. BRUNJES \& SONS BROOKLYN, N. Y.}

\section{RELIABLE SEEDS}

\section{LATE or MAIN GROP PEAS}

Daisy, or Dwarf Telephone. An ideal dwarf wrinkled Pea, maturing earlier than the late, tall-growing kinds. A remarkably fine variety for the private garden, as its vines never exceed 2 feet in height, and the Peas are of excellent flavor. $1 / 2 \mathrm{lb} .20$ cts., $1 \mathrm{~b} .35$ cts., 2 lbs. 65 cts., 10 lbs. $\$ 2.75$.

Alderman. The largest-podded of all Peas, even larger than the Duke of Albany, and also much darker in color. The vines, 4 feet in height, are vigorous, robust and decidedly heavy vielders. $1 / 2 \mathrm{lb} .20 \mathrm{cts}$., lb. 35 cts., 2 lbs. $65 \mathrm{cts}$., $10 \mathrm{lbs} . \$ 2.75$.

Telephone. For general planting, this tall-growing variety is undoubtedly the most popular among market-gardeners. The pods, 4 to $41 / 2$ inches long, are light green in color and filled with large, swect, tender Peas. $1 / 2 \mathrm{lb}$. 20 cts., lb. 35 cts., 2 lbs. 65 cts., 10 lbs. $\$ 2.75$.

Champion of England. A standard Pea; vines grow $41 / 2$ feet high and bear medium-sized pods of Peas of good quality, 1/2lb. 20 ets., 1b. 35 ets., 2 lbs. 65 ets., 10 lbs. $\$ 2.75$.

Duke of Albany. Immense pods, on style of Tclephone; a very superior Pea of quick Luke of Albany. growth; pods dark green, well filled. Height 4 feet. $1 / 2 \mathrm{lb} .20$ cts., lb. 35 ets., 2 lbs. 65 cts., 10 lbs. $\$ 2.75$.

Tall Melting Sugar. The pods as well as the Peas of this varicty are edible and are usually gathered before they are fully matured and cooked similar to snap beans. Pods average about 4 inches in length and when young are tender, stringless, and fine flavored. Height 4 to 5 feet. $1 / 2$ lb. 20 cts., lb. 40 cts., 2 lbs. 75 ets.

\section{Pumpkin}

One ounce will plant 50 hills; 3 to 4 lbs. for one acre

Pumpkins are usually raised in the cornficld. When the corn is about $11 / 2$ fcet high, or after it receives its last cultivation, the seed is sown, dropping three sceds in every third hill. The seed may also be sown after May 15, in hills 8 feet apart, placing about six seeds in each hill and later thin out to four plants.

King of the Mammoths. (Jumbo.) This is indeed a mammoth varicty. The Pumpcolor, flat-shaped, and have thick, bright vellow flesh of excellent quality Pre-yels in

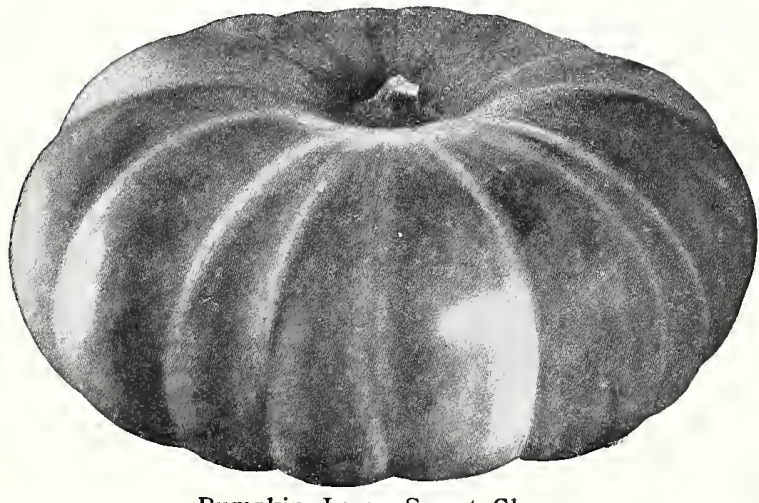

Pumpkin, Large Sweet Cheese 20 cts., $1 / 4$ lb. 50 ets., 1b. $\$ 1.50$.

\section{Large Sweet Cheese.}

Specinens of this sort are usually about 2 fect in diamcter, and one-third as thick. The skin is creamy yellow while the flesh is unsurpassed for making pies. Our strain of this wcll-known variety is very fine and highly esteemed for market or home-garden. Pkt. 5 cts., oz. 15 cts., $1 / 4 \mathrm{lb}$. 40 cts., lb. $\$ 1.25$.

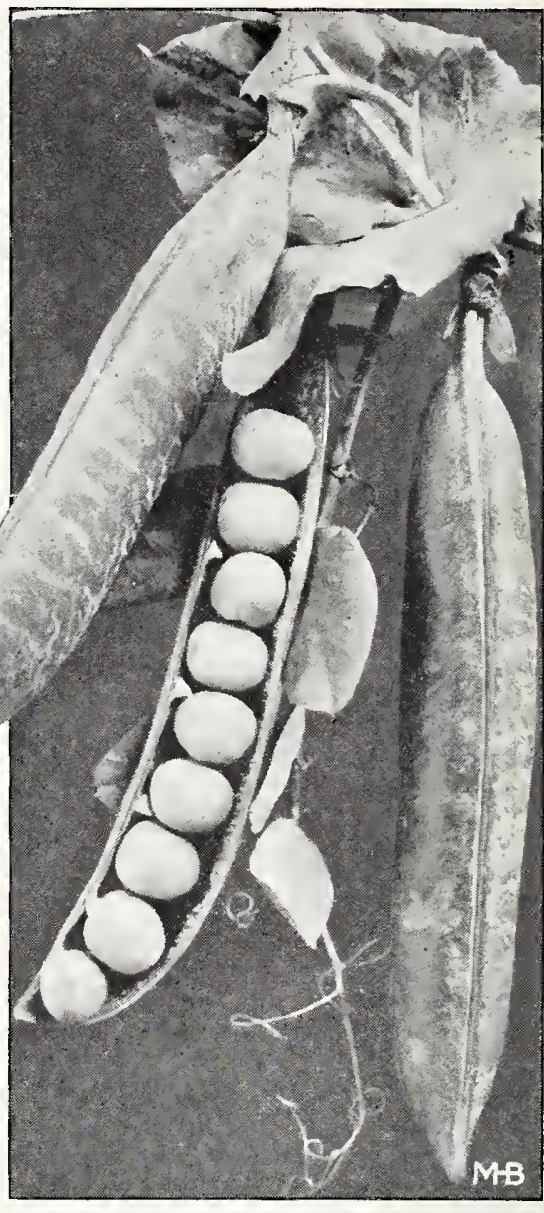

Peas, Telephone

Small Sugar. Though small, the fruit measuring only from 8 to 10 inches in diameter, this is one of the swectest, and is highly recommended for home use. Round, with dark orange-colored skin and thick, solid flesh Pkt. 5 cts., oz. 15 cts., 1/4lb. 40 ets., lb. $\$ 1.25$.

Large Tours. An improved variety noted for its enormous size; specimens of ten measure 3 feet in diameter and wcigh 75 pounds or more. Pkt. 5 cts., oz. 15 cts., 1/4lb. 40 cts., lb. $\$ 1.25$.

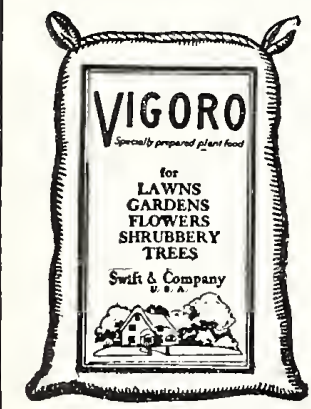

\section{Enjoy Better Vegetables Sooner}

TEED your vegetables. Like all living things they will grow better and faster if given the proper food.

Lawns and flowers respond quickly to a balanced plant-food-grass of deep velvety green-flowers of rich color that bloom longer.

Vigoro, the complete plant-food, meets these demands. Odorless and easy to apply, it furnishes to plant-life all of the different elements necessary for normal, healthy growth.

Two million users have proved its success on lawns, gardens, flowers, shrubs, and trees. Complete directions in every bag.

Include a bag of Vigoro with your order.

5 lbs. 50 cts., 10 lbs. $\$ 1,25$ lbs. $\$ 1.75,50$ lbs. $\$ 3,100$ lbs. $\$ 5$. (If by parcel post add postage at zone rate. 


\section{H. BRUNJES \& SONS \\ RADISH}

BROOKLYN, N. Y.

One ounce will sow 100 feet of drill

For early use select only forcing varieties and sow in lotheds or under glass any time from January until March. Begin sowing outdoors as soon as the soil is in working condition, usually early in April, seleeting, if possible, a light, sandy loam. Although seed of the monthly Radishes may be sown broadeast from April until September, the summer and winter sorts should be sown in drills 12 to 18 inches apart, but not before May 15 , as earlier sowings will most likely run to seed. For winter, sow from July 15 to August 15 in drills 18 inches apart, later thimning out to 6 inches apart.

Crimson Giant. A splendid variety, wrowing almost double and maturing in twenty-five days. It is solid, erisp, and tender, of bright red color, and we recommend it highly. Pkt. 5 cts., oz. 10 cts., $\frac{1}{4}$ lb. 30 cts., lb. 90 cts.

Earliest Carmine Forcing. An extra-early, olive-shaped, deep red Radish with rather small tops, maturing in about twenty days. Pkt. 5 cts., oz. 10 cts., ${ }_{4}^{1}$ lb. 30 cts., lb. 90 cts.

Early Round Dark Red. All that its name implies, as well as being of rapid growth and handsome appearance. Fine for forcing. Pkt. 5 cts., oz. 10 cts., $\frac{11}{4} 1$. 30 cts., 1 b. 90 cts.

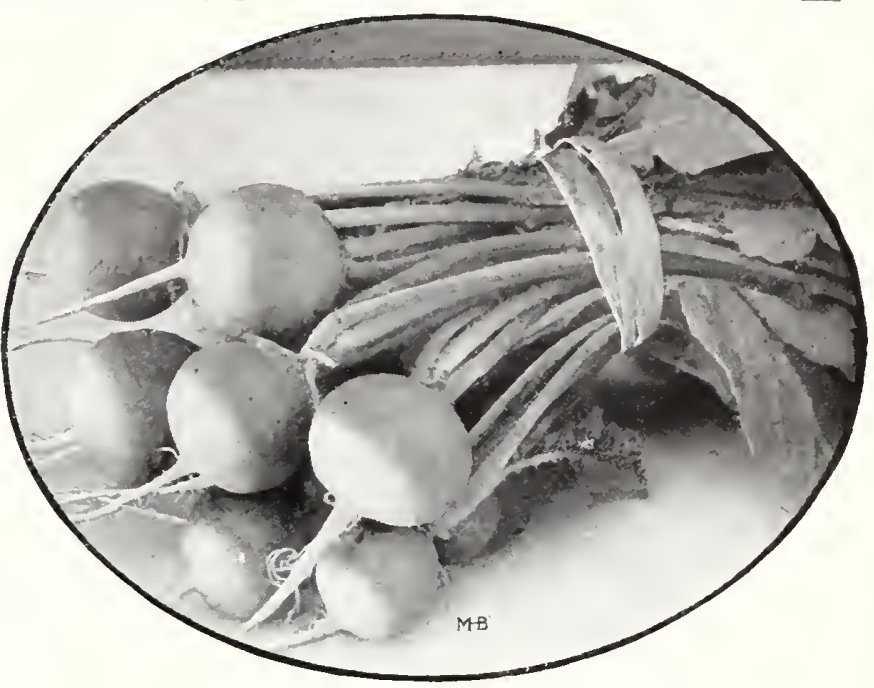

Radish, Early Scarlet Turnip, White-tipped

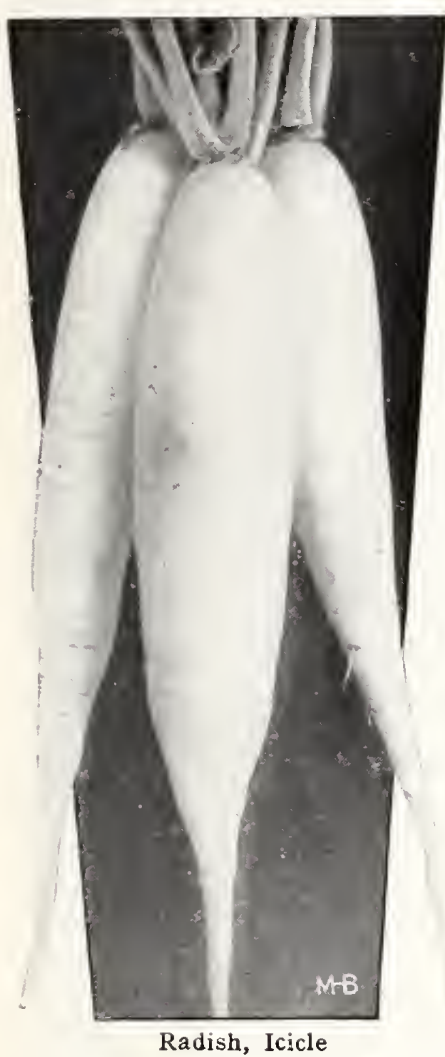

White Strasburg. Handsome, long roots of delicate flavor
when small, but remaining in good condition until maturity. Pkt. $5 \mathrm{c}$. oz. $10 \mathrm{c} .1 \mathrm{~b} .30 \mathrm{c} .1 \mathrm{~h} .90 \mathrm{c}$. top, and rarely becoming pithy. Pkt. 5 cts., oz. 10 cts., $\frac{1}{4} \mathrm{lb} .30 \mathrm{cts}, 1 \mathrm{~b} .90$ ets. and market. Pkt. 5 cts., oz. 10 cts., ${ }_{4}^{1} 1 \mathrm{lb} .30 \mathrm{cts.}$ lib. $90 \mathrm{cts}$.

Early Scarlet Turnip. One of the standard sorts for turnip-shaped, dark red, and of fine quality. Roots are large tops. Pkt. 5 cts., oz. 10 cts., ${ }_{4}^{1} 1$ b. 30 cts., 1b. 90 cts.

French Breakfast. This well-known Radish is olive-shaped, bright scarlet with the exception of the white tip. Pkt. 5 cts., oz. 10 cts. 11 lb. 30 cts. 1b. 90 cts.

Early Scarlet Turnip, White-tipped. An excepfine strain so largely grown by market-gardencrs. Its color is of the deepest scarlet with a prominent white tip; superl, flavor. Pkt. 5 ets., oz. 10 cts., $\frac{1}{1} \mathrm{lb} .30$ ets., lb. 90 cts.

Early White Turnip. Preferred by many to the red sorts. Flesh clear white, tender, and swect. Pkt, 5 cts., oz. $10 \mathrm{cts.}$ $\frac{1}{4} 1$ b. 30 cts., lb. 90 cts.

Icicle. One of the earliest and purest of all long white passed. Pkt. 5 ets., oz. 10 ets., $\frac{1}{4} 1 \mathrm{~b} .30 \mathrm{cts} .1 \mathrm{lb} .90 \mathrm{cts}$.

Long Scarlet Short Top. A long, smooth, tapering Radish somewhat smaller but brighter in color than Chartier. Pkt. 5 cts., oz. $10 \mathrm{cts.}, \frac{1}{1}$ lb. $30 \mathrm{cts.}, 1$ b. 90 cts.

Long White Vienna (Lady Finger). The skin and flesh are both pure white and of excellent quality. Plit. 5 cts., Oz. $10 \mathrm{cts}, \frac{1}{4} 1 \mathrm{~b} .30 \mathrm{cts.}, \mathrm{lb} .90 \mathrm{cts}$.

Early Golden Yellow Oval. Grows from 3 to 4 inches long, oval-shaped, perfectly solid, and skin bright yellow. Pkt. 5 cts., oz. 10 cts., $\frac{1}{1}$ lb. 30 cts., lb. 90 cts.

Giant White Stuttgart. Splendid for summcr use; one of the best for slicing. Pkt. 5 cts., oz, 10 cts., $\frac{1}{4} 1$ b. 30 cts., lb. 90 cts.

White Summer Turnip. An approved variety for the homegarden. The Radish is round, quite large, and decidedly crisp. Pkt. 5 cts., oz. 10 cts. $11 \mathrm{~b}, 30 \mathrm{cts} .1 \mathrm{l}, 90 \mathrm{cts}$.

White Strasburg. Handsome, long roots of delicate flavor

Non Plus Ultra. Especially desirable during the warm summer months, owing to its earliness, short

Scarlet Globe Forcing. We offer an exceptionally fine strain of this Radish which is po ular olive-shed rich bright everywhere either for foreing or outside sowing. The roots are slightly tender. It matures early, usually in about twenty-one days, and is a favorite both for the home garden

Brunjes' Half-long Black Winter. Very lighly recommended as the best Radisl mer. The color of the roots, which grom about 6 inches long and 21 inches across the top, is more of a gray than black, while the flesh is pure white. Pkt. $5 \mathrm{cts}, 0 \mathrm{oz} .10 \mathrm{cts}, \frac{1}{4} 1 \mathrm{~b} .30 \mathrm{cts} .1 \mathrm{~b} .90 \mathrm{cts}$.

Round Black Spanish. Preferred by sone to the longer varieties. Roots round, 3 to 4 inches in diameter, and about the same in length; flesh white. Pkt. 5 ets., oz. 10 cts., ${ }_{4}^{1} \mathrm{lb} .30$ cts., $1 \mathrm{lb} .90 \mathrm{cts}$.

Long Black Spanish. The roots grow about 9 inches long and 2 inches in diameter, and have firm white flesh which is decidedly pungent but well flavored. Grown principally for keeping during the winter; matures late. Pkt. 5 cts., oz. 10 cts., ${ }_{4}^{1} \mathrm{lb} .30 \mathrm{cts} ., 1 \mathrm{~b} .90 \mathrm{cts}$.

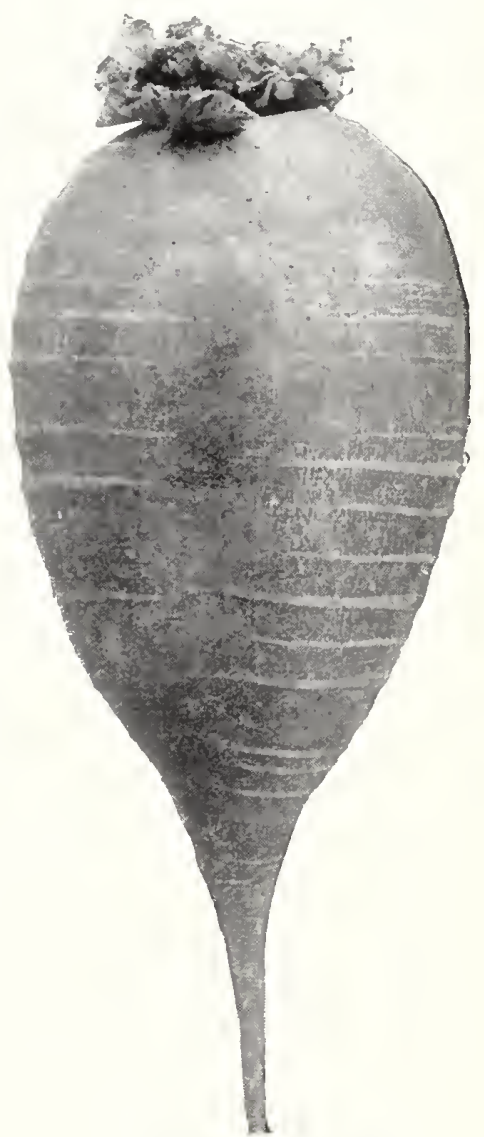

Radish, Half-long Black Winter 


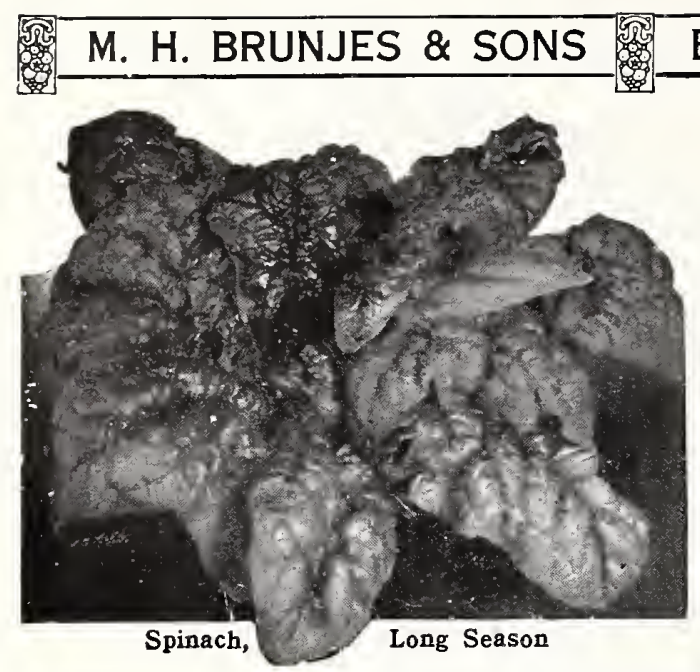

BROOKLYN, N. Y.

RELIABLE SEEDS

\section{SPINA CH $\begin{gathered}\text { One ounce will sow } \\ 50 \text { feet of drill }\end{gathered}$}

First sowings should be made as soon as the ground is open in spring. Sow seed $\frac{1}{2}$ inch deep in drills 1 foot apart and every two weeks thereafter for succession. Sowings made during September usually grow large enough to winter over and with little protection afford Spinach very early the following spring. A rich soil is essential to obtain best results.

Bloomsdale Savoy-leaved. The popular fall Spinach so largely grown crumpled, dark green, and very thick. Pkt. 5 cts., oz. 10 cts., $\frac{1}{4} \mathrm{lb}$. 20 cts., $1 \mathrm{~b} .60 \mathrm{c}$. Improved Thick-leaved. This handsome strain of Spinach is especially useful for spring and summer sowing. Pkt. 5 cts., oz. 10 cts., $\frac{1}{4} \mathrm{lb} .20 \mathrm{cts}$., lb. $60 \mathrm{cts}$.

Long Season. Leaves are decidedly dark green in color, very broad, thick, fact better than all others, and remains a long time in condition for use before going to seed. Pkt. 5 cts., oz. 10 cts., $\frac{1}{4} 1 \mathrm{~b}$. 20 cts., lb. 60 cts.

Long-standing. Succeeds well in almost all seasons and, though rather slow growing, it is a very fine, large, dark green-leaved Spinach. Pkt. 5 cts., oz. 10 cts., $1 / 41$ b. 20 cts., lb. 60 cts.

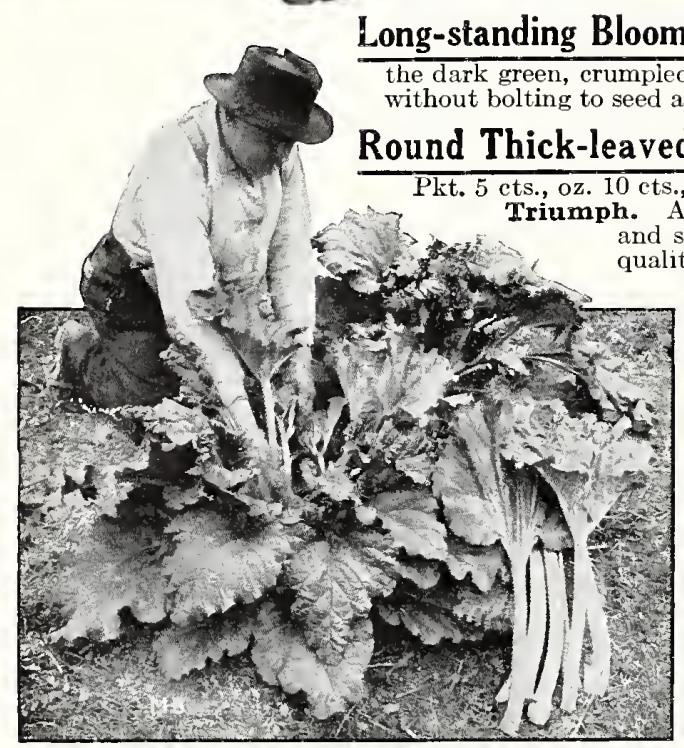

Rhubarb

ale. Although only reccntly introduced, this variety has become very popular with our market-gardeners. Quite similar to the old Bloomsdale Savoy, but cs are thicker and a little more round. It stands unfavorable weather eonditions well as any variety we know. Pkt. 5 cts., oz. 10 cts., 1/4lb. 20 cts., 1 b. 60 cts.

One of the best and most desirable for the home-garden, either for early or late planting. The round, slightly crumpled leaves are both tender and of good quality. $\frac{1}{4} 1$ b. 20 cts., lb. 60 cts. and summer use but for fall sowing as well. The leaves

victoria. It is one of the darkest in color and, with the exception of the heart, the leaves are comparatively smooth. Pkt. 5 c., oz. 10 cts., ${ }_{4}^{1} \mathrm{lb} .20 \mathrm{cts}$., $1 \mathrm{~b} .60 \mathrm{cts}$.

New Zealand. Distinct from the ordinary Spinach in appearance. The plants are more spreading in growth with small, very dark green leaves, which may be had throughout the hot summer months. Sow seed outdoors during May, dropping about three seeds in hills 2 fect apart each way. Pkt. 5 ets., oz. 10 cts., $\frac{1}{4}$ lb. 30 cts., lb. 90 cts.

\section{RHUBARB}

Should be sown during April or May in drills 1 foot apart, covering the seed about $\frac{1}{2}$ inch. Later thin out the seedlings to 4 inches apart and in the fall transplant to permanent beds of well-enriched soil, setting plants not less than 3 feet apart. They will be in condition for use the following year. Pkt. 5 cts., oz. 20 cts., $\frac{1}{4} \mathrm{lb} .50 \mathrm{cts}$.

\section{RHUBARB ROOTS}

Rhubarb may be had one year earlier by planting roots than by sowing the seed. We offer fine, extra-strong roots during April, which is the best month for setting them out. 15 cts. each, $\$ 1.50$ per doz. If by parcel post, add postage at zone rate. Weight, $1 \mathrm{lb}$. each.

\section{SALSIFY, or OYSTER PLANT}

One ounce will sow 75 feet of drill

This vegetable is best grown in a rich, deep but loose soil. Sow seed about 1 inch deep from April to June 15 in drills 12 inches apart. Later thin out to 4 inches in the row. They are usually ready for use in September but become more delicate in flavor after a light frost.

Mammoth Sandwich Island. The roots are white, extra long, straight, and very tender. Pkt. 5 cts., oz. 25 cts., $\frac{1}{4}$ lb. 75 cts., lb. $\$ 2.50$.

\section{SCORZONERA (Black Oyster Plant)}

Should not be sown before May 15, but otherwise is cultivated the same as salsify. The roots are black.

Long Black. Pkt. 5 cts., oz. 20 cts., $\frac{1}{4}$ lb. 60 cts., lb. $\$ 2$.

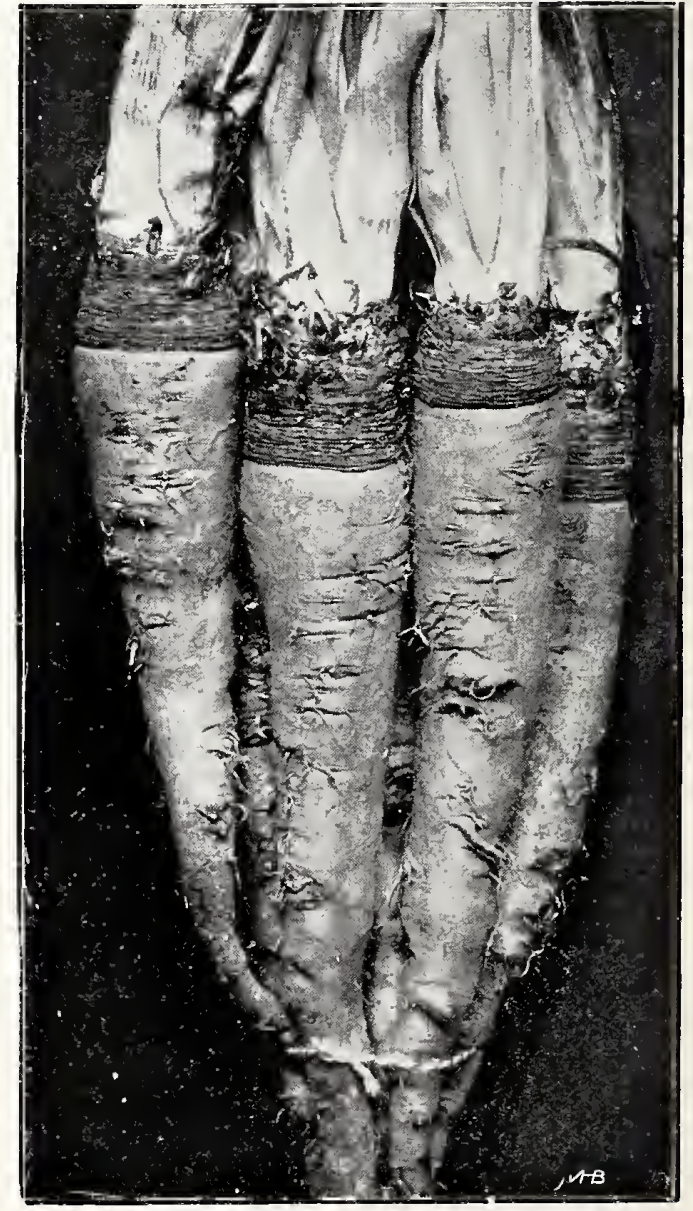

Salsify, Mammoth Sandwich Island 

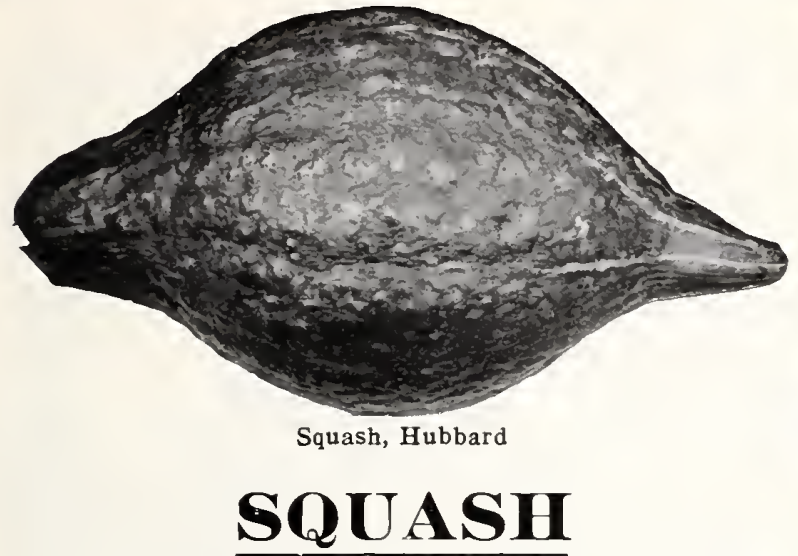

One ounce of Early will plant 50 hills; 1 ounce of Marrow, 25 hills

Not only Squash, but all vine secds should not be sown until the weather is quite warm. Early or summer varieties are planted during MIay in hills 4 feet apart: the winter sorts require from 6 to $s$ feet and are planted in July. Plant eight or ten seeds 1 inch decp in a hill, but later let only three of the strongest plants remain. Soil should be rich and well manured.

Boston Marrow. This popular, oval-shaped winter Squash is Boston Marrow. one of the most uscful for pies. Flesh rich orange, skin yellow. Pkt. 5 cts., oz. 20 cts., ${ }_{4}^{1} 1 \mathrm{~b} .50 \mathrm{cts.}, 1 \mathrm{~b} . \$ 1.50$.

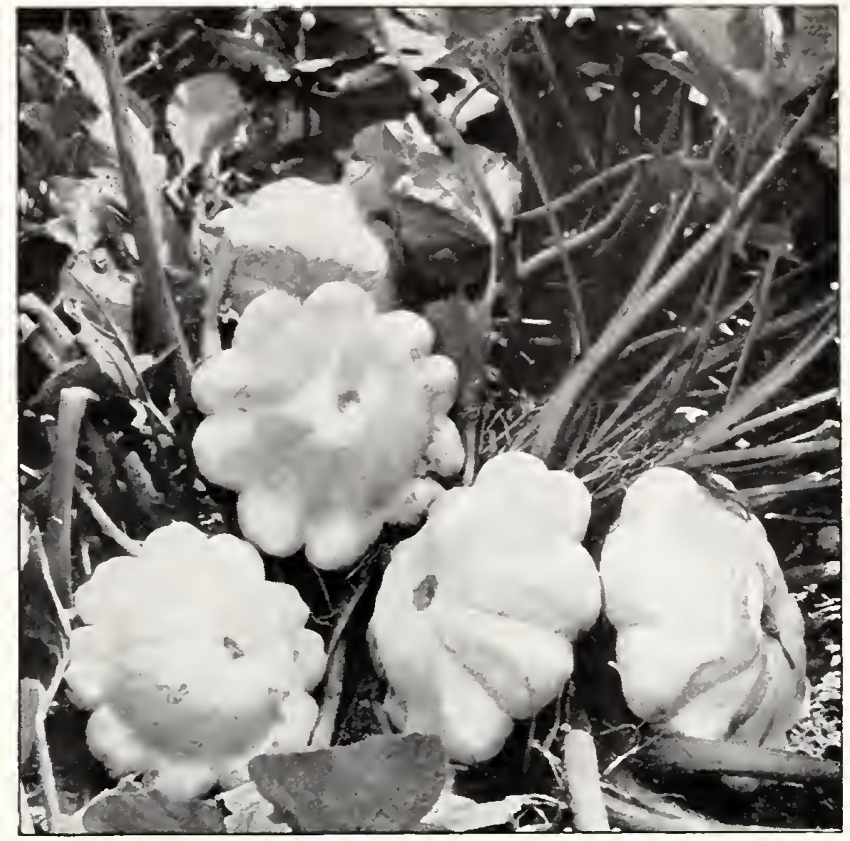

Squash, Mammoth White Bush Scalloped

Cocozella (ltalian Vegetable Marrow). An esteemed Italian variety,

15 to 18 inches in length and about 4 inches in diameter; very dark green, striped with white. Pkt. 5 cts., oz. 20 cts., $\frac{1}{4}$ lb. 50 cts., lb. $\$ 1.75$

Golden Hubbard. In size and shape the same as Hubbard. It is somewhat warted, golden red in color, while the flesh is fine-grained, deep yellow and of extra-rich flavor. Pkt. 5 cts., oz. 20 cts., $\frac{1}{4}$ lb. 60 cts., lb. \$2.

Hubbard. A superior dark green winter variety. Grows very large and is one of the finest for table use. Pkt. 5 cts., oz. 20 cts., $1 \mathrm{lb}$.

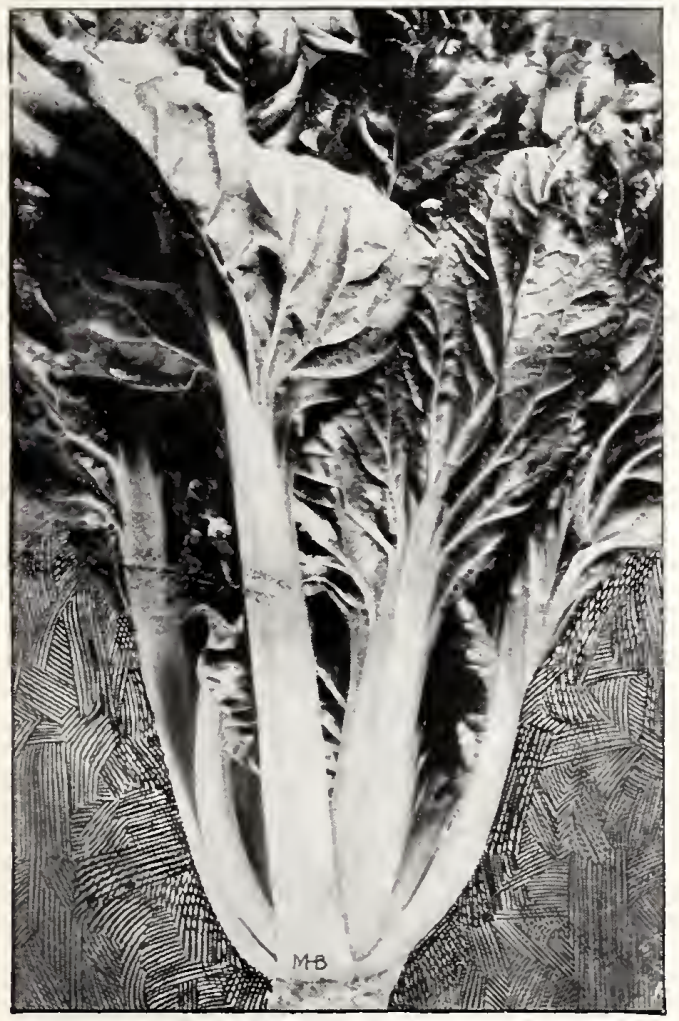

Swiss Chard
Mammoth Summer Crookneck. The largest and most desirable warted and of a beautiful golden eolor. Pkt. 5 cts., oz. 20 cts., 1, 1b. 50 cts., lb. $\$ 1.50$.

Mammoth White Bush Scalloped. An early sort of bush habit. The fruits are uniformly large, pure white and of good quality. Pkt. 5 cts., oz. 15 cts., $1_{4} 1 \mathrm{~b}$. 40 cts.. lb. $\$ 1.25$.

\section{SORREL \\ One ounce will sow 150 feet of drill}

Seed sown during April in drills 12 inches apart and $\frac{1}{2}$ inch deep will be in eondition for cutting about July. For early spring use, a sowing should be made in August. The roots are hardy and if not disturbed will remain for several years. Large-leaved Franch. Pkt. 5 cts., oz. $20 \mathrm{cts} ., \frac{1}{4} \mathrm{lb} .50 \mathrm{cts.,}$ lb. $\$ 1.50$.

\section{SWISS CHARD, or SPINAGH BEET}

\section{One ounce will sow 100 feet of drill}

No matter how small the garden, a place should be reserved for this vegetable. The leaves grow quite high and when broken off and cooked like spinach are preferred by many to the latter. By using the outer leaves new ones will always form. Sow sced early in spring in rows 15 inches anart and later thin out to 6 inches in the row. Pkt. 5 ets., oz. 15 ets., $\frac{1}{4}$ lb. 40 cts., lb. $\$ 1.25$.

Giant Lucullus. This valuable vegetable has replaced spinach in many gardens. The plants grow about 2 feet high, have large, , which are cooked like spinach. The stalks may be cooked and similar to asparagus. Pkt. 5 cts., oz. 15 cts., $\frac{1}{4} \mathrm{lb} .40$ cts., 1b. $\$ 1.25$.

\section{TOBACCO}

One ounce will produce plants for one acre

Seed may be sown under glass from February to April or in a sheltered bed outdoors after all danger from frost is over, usually late in May. When the plants are 5 to 6 inches high transplant to beds of good, rich soil, setting plants about 4 feet apart cach way and cultivate frequently, as for corn.

Connecticut Seed Leaf. A very popular and one of the hardiest and most largely grown varieties. Pkt. 10 ets., oz. 30 ets., $\frac{1}{4}$ lb. $\$ 1$, lb. $\$ 3.50$.

Imported Havana. Has very thin leaves of fine texture. Pkt. $10 \mathrm{cts.}, 0 z .40 \mathrm{cts}$. $\frac{1}{1 b} \mathrm{lb} . \$ 1.25,1 \mathrm{~b} . \$ 4.50$. 


\section{H. BRUNJES \& SONS BRO BRLOKL, N. Y.}

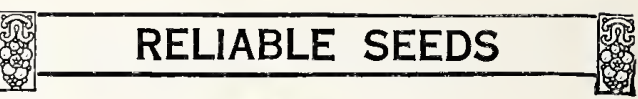

\section{TOMATO}

For early Tomatoes start plants in hotbeds during March, sowing the seed $\frac{1}{4}$ inch deep in drills 6 inches apart. They should be replanted at least once in the frames before the final planting outdoors in May, after all danger of frost is past. It is unwise to set plants eloser than 3 to 4 feet apart each way, as the vines grow vigorously and soon cover the entire space. In gardens where space is limited and only a few plants grown, we recommend the use of tomato supports.

Brunjes' Stone. This is the most popular and largely of this variety is exceptionally fine and we can recommend it highly to the most eritical grower. The fruit is extra large, very smooth, exccedingly heavy and of a handsome, brilliant scarlet color, while the shape is round and slightly flattened. Pkt. 5 cts., oz. 35 cts., $1 / 4 \mathrm{lb}$. $\$ 1.10$, lb. $\$ 3.75$.

Break o'Day. An extra-early variety of the Marglobe type. The scarlct fruit of medium size, is smooth, globe-shaped, very solid with fcw sceds. Pkt. 10c., oz. 50c., 1/4b. \$1.75, lb. \$6.50.

Bonny Best. A beautiful, bright scarlet Tomato for the homegarden, maturing about the same time as Early Jewel. The vines are of good sturdy growth and heavy yielders of round, deep fruit, very solid and unsurpassed in quality. Pkt. 5 cts., oz. 40 cts., $\frac{1}{4}$ lb. $\$ 1.25$, lb. $\$ 4$.

Dwarf Stone. A very desirable sort for the home garden. The vines are dwarf but vigorous and productive, while the bright red fruit is of good size, very solid and exceedingly smooth. Pkt. 5 cts., oz. 40 cts., ${ }_{4}^{1} 1 \mathrm{l}$. $\$ 1.25,1 \mathrm{~b}$. $\$ 4$.

Brunjes' Earliana. An exceedingly carly Tomato of decp red color. The and produced in large clusters on short, compact bushes. Every grower of Tomatoes should include a packet of this sterling variety in his order. Pkt. 5 cts., oz. 40 cts., $\frac{1}{4} \mathrm{lb} . \$ 1.25$, lb. $\$ 4$.

Early Jewel. This variety is somewhat larger than Earliana but matures Early Jewel. nearly a week later. The fruit is round, very meaty and of handsome bright scarlet color. One of the best for the home-garden. Pkt. 5 cts., oz. 40 cts., $\frac{1}{4}$ lb. $\$ 1.25$, lb. $\$ 4$.

John Baer. Our customers will find John Baer one of the best large, carly John Baer. Tomatoes. It matures shortly after Earliana, is an abundant cropper, and continues to bear longer than most early varieties. The fruit is almost round, bright scarlet, very solid, and has small seed-cavity. Pkt. 10 ets., oz. 40 cts., $\frac{1}{4}$ lb. $\$ 1.25$, lb. $\$ 4$.

Golden Queen. Rich golden yellow, equal to the red sorts, both in size and flavor. Pkt. 5 cts., oz. 35 cts., $\frac{1}{4}$ lb. $\$ 1.10$, ib. $\$ 3.75$.

Greater Baltimore. A midseason or main-crop variety equally desirable either for the market gardener or for growing in the homegarden. The bright red fruit is of medium size, averaging about a half pound, very solid and meaty, and extensively used for canning. Pkt. 5 cts., oz. 35 cts., $\frac{1}{4} 1 \mathrm{~b} . \$ 1.10,1 \mathrm{~b} . \$ 3.75$.

Marglobe. This new, medium-early, globe-shaped Tomato, developed by the U. S. Department of Agriculture, has become very Marglobe. popular due to its rust- and wilt-resisting qualities. The plants are of strong, vigorous growth and very productive, while

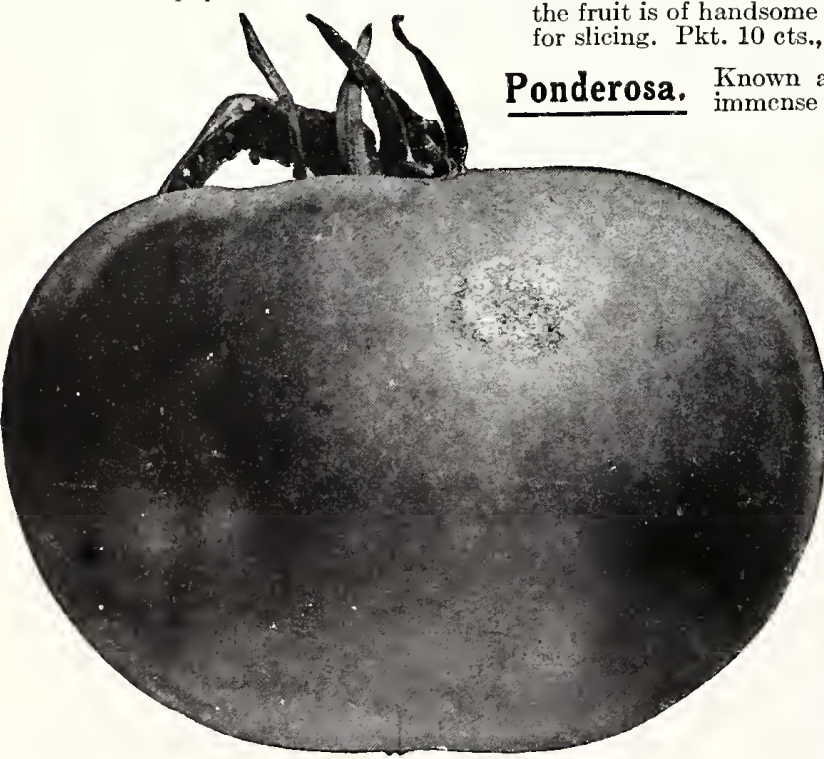
for slicing. Pkt. $10 \mathrm{cts}$, oz. 50 cts., $\frac{1}{4} \mathrm{lb} . \$ 1.75,1 \mathrm{~b} . \$ 6$.

Bonny

Best

Tomatoes

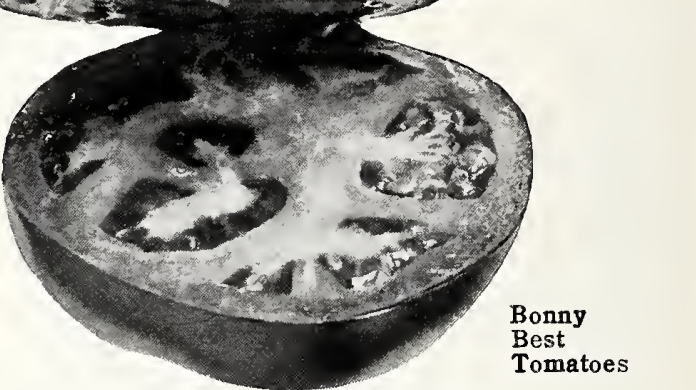




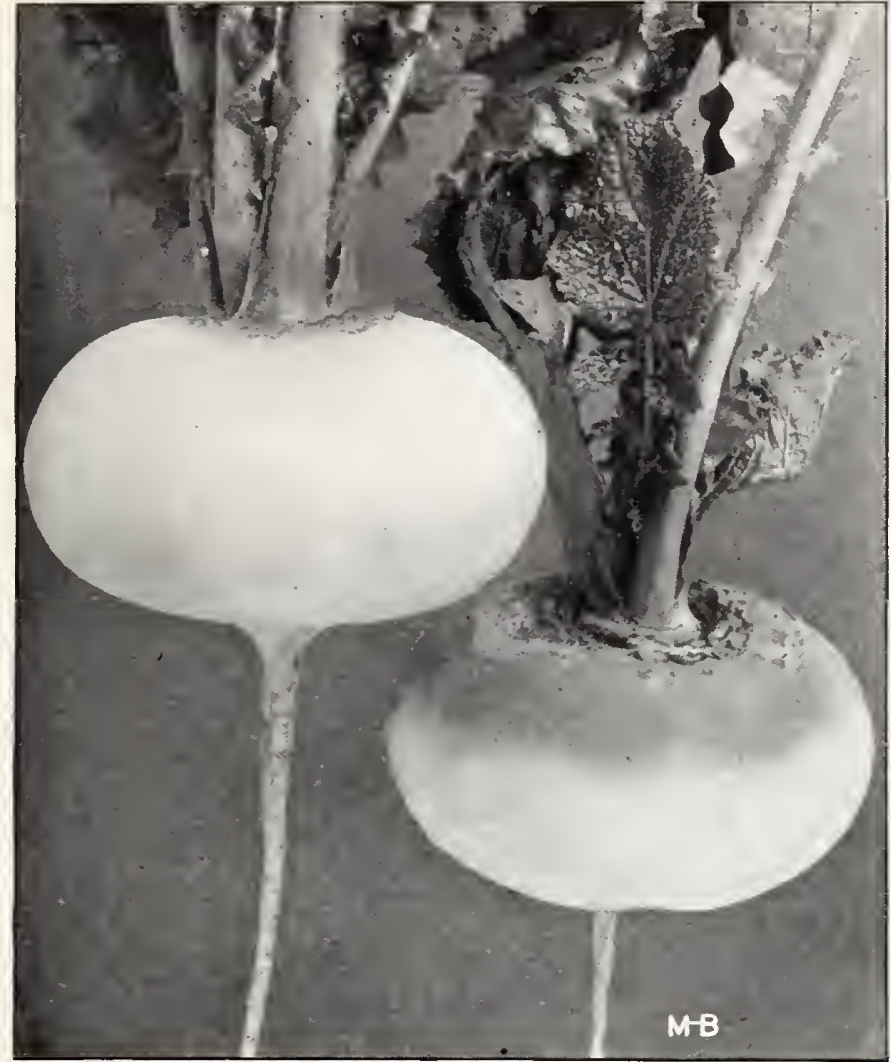

Turnip, Extra-Early White Milan Turnip, Purple-Top White Milan

\section{TURNIP}

One ounce will sow 100 feet of drill; two pounds will sow one acre

For early use sow in hotbed during $\mathrm{M}$ arch, selecting either of the Milan varieties. Sowings may be made outdoors in drills 12 inches apart as soon as the ground can be worked in spring, and later thin out to 5 inehes in the row. For suceession sow at intervals of a fortnight until the last week of July, from which time until the end of August, sowings should be made for the late crops.

Early Snowball. A first-class table variety with small, round, ball-shaped roots of the purest white; very tender. Pkt. 5 ets., oz. $10 \mathrm{cts},{ }_{1}^{1} \mathrm{lb}, 25 \mathrm{cts} ., 1 \mathrm{~b}, 75 \mathrm{cts}$.

Extra-Early White Milan. Exeeptionally fine for early outdoors. The bulb is snooth, flat and of medium size. Pkt. 5 cts., oz. 15 cts. $1 / 1$ lb. 40 ets., lb. $\$ 1.25$.

Purple-Top White Milan. Almost identical in size and shape with the preceding but with purple crown. The flesh is white sweet and fine flavored. Pkt.5c, oz. 15c., 1/4 lb. 40c, lb. $\$ 1.25$.

Purple-Top Strap-leaf. A flat, quick-growing variety, popular either for spring or fall. Pkt. 5 ets., oz. 10 ets., $\frac{1}{4} 1 \mathrm{~b} .25$ cts. lb. 75 cts.

Purple-Top White Globe. One of the best and most proThe roots are globe-shaped, extra large, and very solid; flesh fine grained and purest white. For winter use sowings should be made about August 20. Pkt. 5 ets., oz. $10 \mathrm{cts.,} \frac{1}{4} 1 \mathrm{~b} .25 \mathrm{cts}$., lb. 75 cts.

Seven Top. The roots are of no particular use al though the leaves, for which it is chiefly grown, furnish greens throughout the wintes in southern states. Pkt, 5 ets, oz, $10 \mathrm{cts}, 11 \mathrm{l}, 25 \mathrm{cts}, \mathrm{lb}, 75 \mathrm{ets}$

Yellow Stone. Keeps well during winter. Color of skin and flesh is bright yellow, the latter being firm, swect, and tender. Pkt. 5 cts., oz. 10 cts., $\frac{1}{16}$ b. 30 cts., lb. 90 cts.

\section{RU'TABAGA (Russian or Swede Turnip)}

One ounce will sow 100 feet of drill; two pounds for one acre

Sow seed from middle of June to July 15 , in drills $1 \frac{1}{2}$ to 2 feet apart, later thinning the plants to $x$ inches in the row. They should be pulled before severe weather and, after removing the tops, stored in the cellar or pit outdoors.

Long Island Improved. We offer an cxceptionally fine strain of this popular winter Turnip. Large, well-shaped roots, short neck, and of a bright ycllow color with purple top. The finest of all for table use; flesh sweet, tender, and solid. A good heeper and largely grown for stock-feeding. Pkt. 5 cts., oz. $10 \mathrm{cts},{ }_{4}^{1} 1 \mathrm{~b}, 25 \mathrm{cts} ., 1 \mathrm{~b} .80 \mathrm{cts}$.

\section{Herbs, Sweet, Pot and Medicinal}

Do not fail to devote a small space in your garden to the cultivation of herbs. Sow during May or June in drills 1 foot apart, covering the seed very lightly and later thin out or transplant to 6 inches in the row. Before in full blossom the plants should be cut, tied in sunall bunehes and hung up in the shade to dry, after which they are placed in boxes or bottles for winter use

Anise (Pimpinella Anisum). Biennial.

Basil, Sweet (Ocimum Basilicum). Annual

Caraway (Carum Carui). Perennial.

Coriander (Coriandrum sativum). Annual.

Catnip (Nepeta cataria). Perennial.

Horehound (Marubium vulgare). Perennial.

Hyssop (Hyssomes officinalis), Perennial

Lavender (Lavandula spica). Perennial.

Marjoram, Sweet (Origanum Majorana). Annual

Rosemary (Rosemarinus officinalis). Perennial

Rue (Ruta graveolens). Perennial.

Safiron (Carthamus tinctorius). Annual .

Sage (Salvia officinalis). Annual.

Summer Savory (Satureia hortensis). Annual.

Thyme, Broad-leaved (Thymus vulgaris). Perenni.1

Wormwood (Artemisia Absinthium). Perennial

$\begin{array}{rr}\text { Pkt. } & \text { Oz. } \\ \text { so } 05 & \text { so } 20 \\ 05 & 15 \\ 05 & 15 \\ 05 & 10 \\ 10 & 60 \\ 10 & 30 \\ 10 & 30 \\ 10 & 35 \\ 10 & 35 \\ 10 & 75 \\ 10 & 50 \\ 10 & 30 \\ 10 & 35 \\ 10 & 25 \\ 10 & 50 \\ 10 & 35\end{array}$

SEEDS BY PARCEL POST.-Orders for packets, ounces, and quarter-pounds will be sent by parcel post, postage free, at prices given. For larger quantities, add postage at zone rates. See inside of front cover page before making out your order.

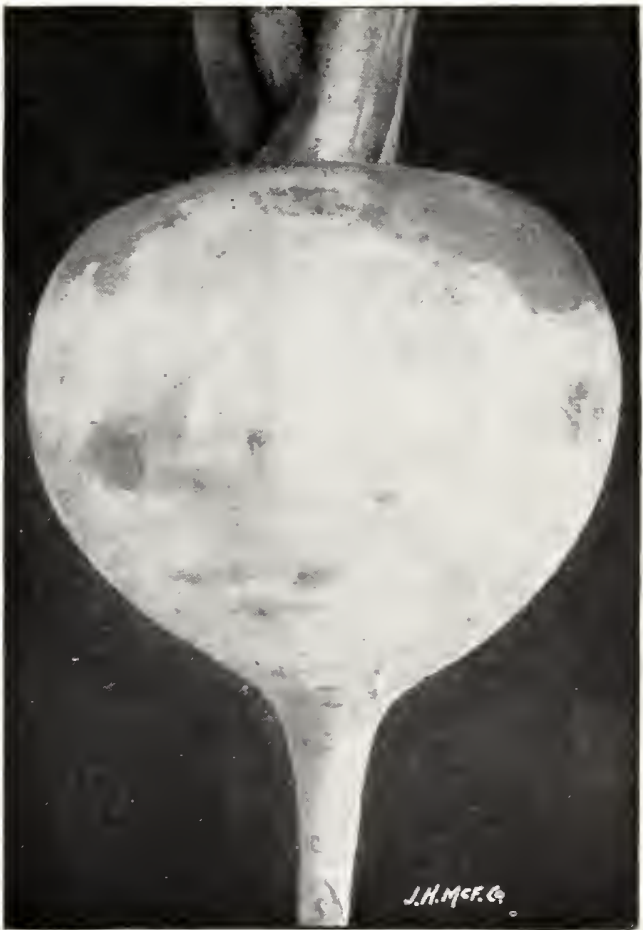

Turnip, Purple-Trp White Globe 


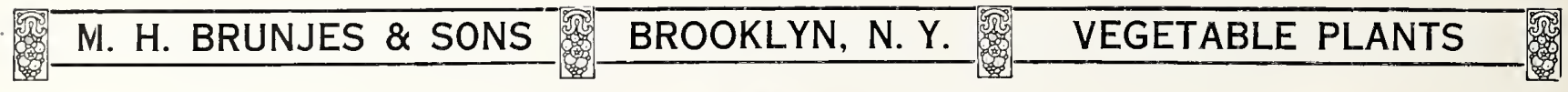

\section{VEGETABLE PLANTS}

If wanted by parcel post, add postage at zone rates. One dozen plants will average one pound. Our plants are grown in flats containing 100 each. Less than 100 plants of one variety will be charged at dozen rates.

CABBAGE. Ready May 1. All Head Early, American Drumhead Savoy, Mammoth Rock Red. 25 cts. per doz., $\$ 1.75$ per 100.

CAULIFLOWER. Ready May 1. Early Snowball. $25 \mathrm{cts}$. per doz., $\$ 1.75$ per 100 .

CELERY. Ready May 1. Soup or Cutting. 25 cts. per doz., $\$ 1.75$ per 100.

CELERY. Golden Self-blanching. Strong, transplanted plants. Ready July 1. 25 ets. per doz., $\$ 1.75$ per 100.

CELERIAC. Ready May 1. Large Smooth Praguc. 25 cts. per doz., $\$ 1.75$ per 100 .

EGGPLANTS. Ready May 15. New York Improved Purple. 50 ets. per doz., $\$ 3.50$ per 100 .
KOHLRABI. Rcady May 1. Early White Vienna. 20 cts. per doz., $\$ 1.40$ per 100 .

LETTUCE. Ready May 1. Big Boston. 25 cts. per doz., $\$ 1.75$ per 100.

PEPPER PLANTS. Ready May 15. Large Bell, or Bull Nose. 30 cts. per doz., $\$ 2$ per 100 .

RHUBARB ROOTS. 15 ets. each, $\$ 1.50$ per doz. If by parcel post, add postage at zone rate. Weight, $1 \mathrm{lb}$. each.

\section{TOMATO PLAN'TS Ready May 1}

Ponderosa. 35 cts. per doz., $\$ 2.50$ per 100 .

Early Jewel, Stone. 30 ets. per doz., \$2 per 100.

\section{FARM SEEDS}

Prices are subject to market changes

CANADA FIELD PEAS, White. Pk. $\$ 1.75$, bus. (60 lbs.) $\$ 6$.

SPRING VETCHES. Grown for soiling, or sown with oats for feeding green. Two bushels will sow one acre. Bus. (60 lbs.) $\$ 6.50$.

BUCKWHEAT, Japanese. Matures early, is a heavy yielder and makes the best flour. Sow one-half bushel, broadcast, to the acre, about the middle of June. Bus. (48 lbs.). Market price,

DWARF ESSEX RAPE. Sown from April to July, it forms an excellent pasturage for sheep and besides is one of the best green fecds for other cattle. Sow $10 \mathrm{lbs}$. to the acre broadcast, and 5 lbs. in drills about 15 inches apart. Lb. 25 cts., bus. (50 lbs.) $\$ 7.50$.

MILLET, German, or Golden (Panicum miliaceum aureum). Grows from 3 to 5 feet high, and on good soil produces a large crop of hay. Sow 1 bushel to the acre. Bus. (50 lbs.) $\$ 4$.

MAMMOTH RUSSIAN SUNFLOWER. The tall-growing plants form inmense-sized heads, containing a large quantity of striped seed which is fine for feeding to fowls. Four pounds will sow one acre. Lb. 15 cts., 100 lbs. $\$ 12$.

\section{FIELD CORN $\begin{gathered}14 \text { pounds will } \\ \text { plant one acre }\end{gathered}$}

If wanted by parcel post, add postage at zone rates

Improved Leaming. (Dent.) Matures quite carly, adapted to almost all soils and is largely planted in both the northern and southern states. The long, tapering ears have golden yellow grains of medium size and, on an average, two are produced on each stalk. Lb. 15 cts., 7 lbs. ( $1 / 2 \mathrm{pk}$.) $75 \mathrm{c}$., 14 lbs. (pk.) $\$ 1.25,56$ lbs. (bus.) $\$ 4.50$.

Queen of the Prairie (Pride of the North). One of the earliest yellow dent varicties maturing in about 85 days. The ears are of medium size, with deep yellow kernels; cob bright red. Lb. 15 cts., 7 lbs. (1/2pk.) 75 cts., 14 lbs. (pk.) $\$ 1.25,56$ lbs. (bus.) $\$ 4.50$.

Silver King. Ears about 9 inches long, 12-rowed and well filled with deep-grained kernels. The earliest white dent variety. Lb. $15 \mathrm{cts}$., 7 lbs. (1/2pk.) 75 ets., 14 lbs. (pk.) $\$ 1.25,56$ lbs. (bus.) $\$ 4.50$.

Longfellow. (Flint.) Particularly adapted for growing in the North. Ears 12 to 15 inches long and $11 / 2$ inches in diameter; 8-rowed, large broad grains and small cob. Lb. 15 cts., 7 lbs. (1/2pk.) 75 cts., 14 lbs. (pk.) $\$ 1.25,56$ lbs. (bus.) $\$ 4.50$.

WHITE SANFORD. (Flint.) Medium-sized ear, 8-rowed, kernels large, broad and of a silvery white color; very productive. Lb. 15 ets., 7 lbs. (1/2pk.) 75 cts., 14 lbs. (pk.) $\$ 1.25$, 56 lbs. (bus.) $\$ 4.50$.

\section{GRASS AND CLOVER SEEDS}

Prices subject to changes. Special quotations for large quantities. If wanted by parcel post, add postage at zone rates

Crested Dog's-tail (Cynosurus cristatus). For lawns and pastures. 1 to $1 \frac{1}{2}$ fcet. $30 \mathrm{lbs}$. to the bushel. Lb. $60 \mathrm{cts}$., bus. $\$ 15$.

Kentucky Blue Grass (Poa pratensis). Fancy cleancd. The standard grass for lawns and pastures. Largely grown and very nutritious. Sow 3 bushels to the acre. 21 lbs. to the bushel. Lb. 35 cts., 10 lbs. $\$ 3,100$ lbs. $\$ 25$.

Orchard Grass (Dactylis glomerata). It is extremely early and desirable to mix with other grasses for pasture or hay. Particularly adapted to shady places. 14 lbs. to the bushel. Lb. 40 cts., bus. $\$ 5$.

\section{CLOVERS}

If wanted by parcel post, add postage at zone rates

Alfalfa or Lucerne. Prized as a forage plant and yields an immense crop of hay on loose, rich soil. Sow 20 to $30 \mathrm{lbs}$. to the acre. Lb. 50 cts., 10 lbs. $\$ 4.50,100$ lbs. $\$ 38$.

Alsike (Trifolium hybridum). Percnnial. Sow with other grasses, when it is excellent for pasturage or hay. Lb. $40 \mathrm{cts}$., $10 \mathrm{lbs}$. $\$ 3.50,100$ lbs. $\$ 30$.

Crimson (Trifolium incarnatum). An annual Clover, largely used for green manure. Sow in August or September. Lb. 30 cts., 10 lbs. $\$ 2.50$, 100 lbs. $\$ 20$.

Medium Red (Trifolium pratense). When used with Timothy makes cxcellent hay; also used for soiling. Lb. $50 \mathrm{c} ., 10 \mathrm{lbs}$. $\$ 4.50,100 \mathrm{lbs}$. $\$ 40$. White (Trifotium repens). The best variety for lawns and also included in permanent mixtures. Lb. 75 cts., 10 lbs. $\$ 7$, 100 lbs. $\$ 60$.

\section{BIRD SEED}

If wanted by parcel post, add postage at zone rates

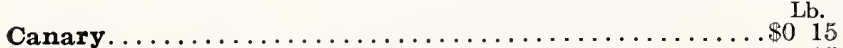

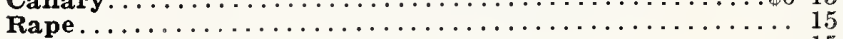

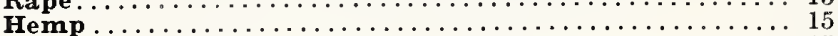

Mixed Canary Seed.

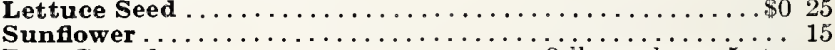

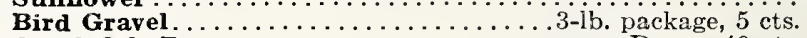

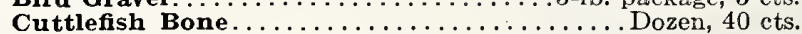




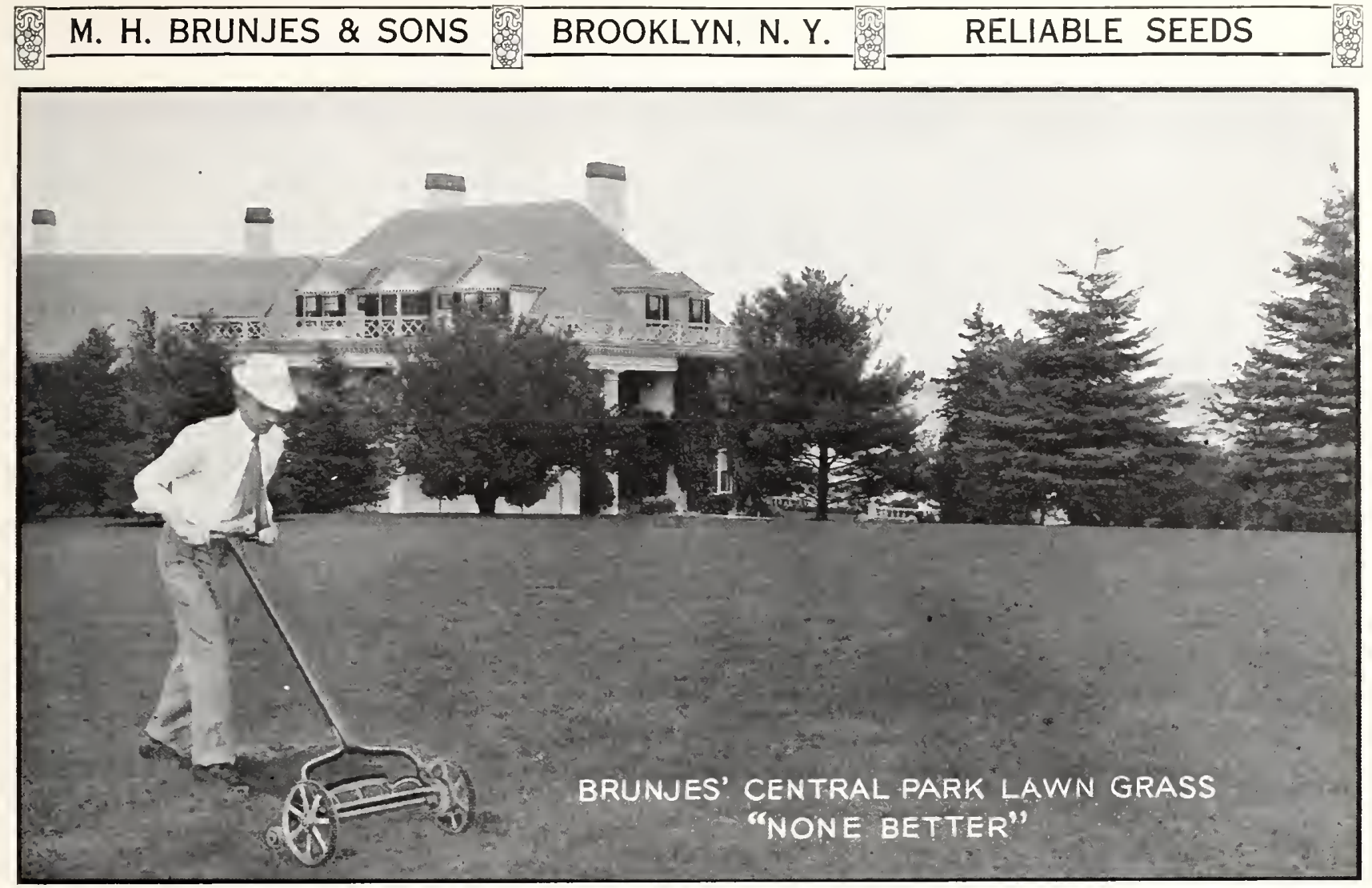

\section{H. BRUN.JES \&. SONS \\ Choice Central Park Lawn Grass}

\section{The Finest Lawns Ire Made from 'This Mixture}

Weight, 20 lbs. per bushel

A beautiful lawn always adds to the attractiveness of the home, and we can truthfully say that many of the finest lawns have been produeed from our Choiee Central Park Lawn Grass Mixture. It weighs 20 pounds to the bushel, and is eomposed of the finest dwarf evergreen grasses, which mature during different months, thus insuring a thick, rich, relvety green lawn almost through the year. Although the greater number of lawns have been made by' sowing the seed in spring, usually from the end of March until July, equally good results can be ohtained from fall-sown seed. In the early spring a dressing of our Lawn Invigorator, Bone Meal, or sheep Manure is very beneficial. In making a lawn it should always be remembered to sow the seed thiekly. One quart will sow $15 \times 20$ feet (300 square feet), 1 bushel $100 \times 108$ feet $(10,800$ square feet), 1 bushels one acre ( 13,560 square feet).

Qt. 30 cts., 2 qts. 55 ets., 4 qts. $\$ 1$, pk. \$1.75, bus. (20 lbs.) \$6.50. If wanted by parcel post, add postage at zone rates. One quart weighs $3 / 4 \mathrm{lb}$. Full directions for making a lawn printed on each box

\section{H. BRUN.JES S. SONS' Shady Nook Lawn Grass}

In shady places, espeeially under trees, may often be seen bare spots which spoil the appearance of the balanee of the lawn. For such places we can recommend this mixture, as it contains only those grasses suited for growing in shady places. Use the same quantity of seed as given above, Qt. 35 ets., 2 qts. 65 ets., 4 qts. $\$ 1.25$, pk. $\$ 2.25$, bus. $(20$ lbs.) $\$ 8.50$. If wanted by parcel post, add postage at zone rates. One quart weighs $3 / 4 \mathrm{lb}$.

\section{South German Bent Grass}

For the past few years there has been a steadily growing demand for Bent Cirass, especially by golf clubs, large estates, and snallhome owners. It is one of the finest lawn grasses, and with a little added care and attention will produce a wonderful turf of deep, velvety green. $1 / 4$ lb. 40 cts., $1 / 21 b$. 65 cts., $1 b . \$ 1.25,5$ lbs. $\$ 5.50,10$ lbs. $\$ 10$. If wanted by parcel post, add postage at zone rates. 


\begin{tabular}{|c|c|c|}
\hline M. H. BRUNJES \& SONS & BROOKLYN, N. Y. & RELIABLE SEEDS \\
\hline
\end{tabular}

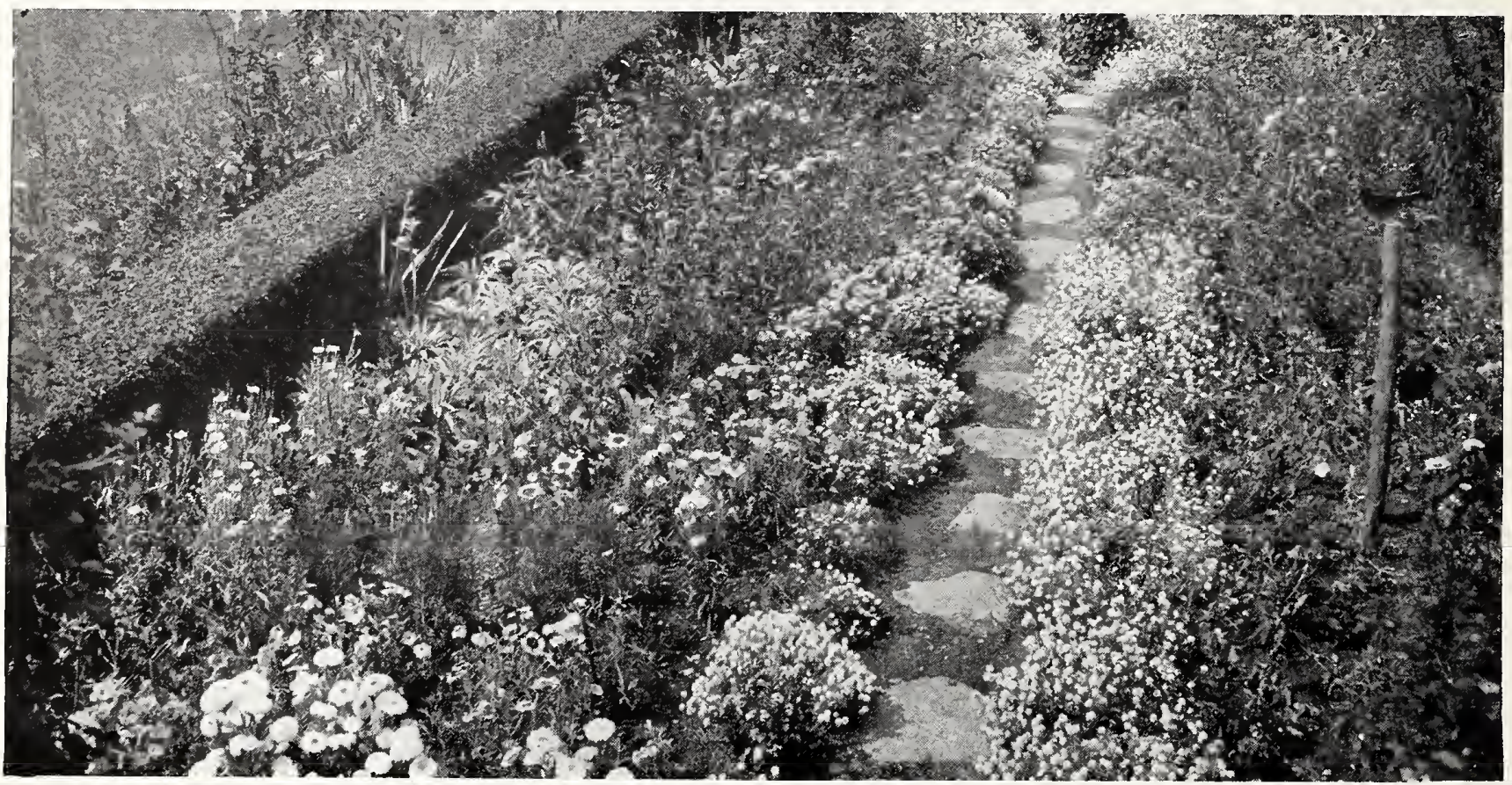

\section{H. BRUNJES \& SONS

The following Abbreviations are used throughout the Flower Seed portion of our Catalogue

H. A. H.

... Hardy Annuals.

Hardy Perennials.

Half-Hardy Peren

H. H. B.
G. C. : :
G. S.

Full directions for sowing FLOWER SEEDS printed on each packet

WE PREPAY POSTAGE ON ALL FLOWER SEEDS IN PACKETS AND OUNCES

ABRONIA Umbellata (Sand Verbena). A pretty trailing annual with rosy lilac sweet-scented, verbena-like flowers, suit- Pkt. ed for hanging-baskets and vases. Prefers a sandy soil. $\frac{1}{2} \mathrm{ft} . . \$ 005$

ABUTLON. Bell-shaped perennial shrubs, of easy cultivation and valuable as a house-plant in winter and for the garden in summer. $3 \mathrm{ft}$. G. S. Finest Mixed Hybrids

ACHILLEA, The Pearl. From June to October this hardy perennial, growing about $1 \frac{1}{2}$ feet high, is a mass of pure white double flowers.

ACONITUM Napellus. Long spikes of blue hood-shaped flowers. Tall growing plants suitable for hardy borders and thriving best in shady locations. $4 \mathrm{ft}$. H. P.......
ACROCLINIUM. These splendid Everlastings are pretty as garden annuals or may be gathered when the buds first open and preserved for winter. $1 \mathrm{ft}$.

Double Mixed. Rose and White......... $15 \mathrm{cts} . . \$ 0$ Pkt. ADLUMIA cirrhosa (Mountain Fringe). $\ddot{A}$ hardy biennial climber with feather-like foliage and innumerable small, tube-shaped rose flowers. Height, $15 \mathrm{ft} \ldots \ldots \ldots \ldots \ldots$. ADONIS estivalis (Flos Adonis). The single, scarlet flowers are bright and showy, contrasting well with the finecut, dark green foliage. $1 \mathrm{ft}$. H. A.......... 25 cts.. .

Vernalis. A perennial blooming in May; large, bright yellow flowers. $1 \mathrm{ft} . . . \ldots \ldots \ldots \ldots \ldots \ldots \ldots \ldots$. oz. $20 \mathrm{cts} .$. .

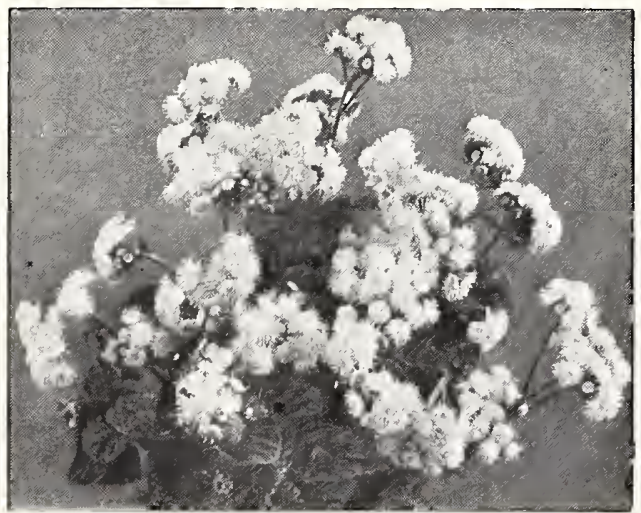

Ageratum, Blue Perfection

\section{AGERATUM}

This everblooming annual is of the easiest culture and one of the leading bluefowered plants, whether for bordering or bedding. Its rich blue flowers are formed in clusters and at times fairly cover the entire plant. Pkt. $1 / 40 z$.

Blue Perfection. Flowers of the largest size and deepest blue. 8 inches $\$ 0 \quad 05 \$ 025$

Blue Star. A handsome miniature variety growing only 5 inches high.

Plants are one mass of bright blue flowers................... 10

Imperial Dwarf Blue. A splendid free-flowering sort. Fine for bedding.

A very popular blue variety. 8 inches........................ 05

Imperial Dwarf White. Similar to the above but having flowers of the

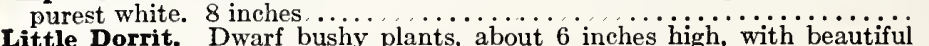

azure-blue flowers. Fine for pot culture .................... 05

AGROSTEMMA Coli-rosa (Rose of Heaven). A free-blooming annual, not more than $1 \frac{1}{2}$ feet high, having bright rose-colored flowers which are

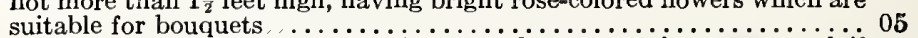

Coronaria. (Rose Campion). Effective when grown in masses and if sown early, blooms the first season. Single, dark red flowers and gilvery white foliage. H. P............................ 


\section{ALYSSUMI}

Very desirable for edging. The seed germinates quickly and the pure white flowers begin to appear about one month later. The plants are dwarf, spreading, and continue to bloom sometimes as late as November. H.A.

Carpet-of-Snow. The most popular variety of this superior bordering plant

growing about 4 inches high, and blooming continuously from spring until Pkt. $\quad \mathrm{Oz}_{\text {. }}$

frost. The flowers are pure white.

Little Gem. A splendid sort growing somewhat higher than Carpet-of-snow $10 \quad 50$ Lilac Queen. A new annual variety of Sweet Alyssum, the plants being of

upright growth and bearing pure lilac flowers................. 10

Saxatile compactum (Basket of Gold). Bright golden perennial sort blooming early in the spring.

IARANTHUS. Ornamental foliage plants preferring a warm, dry situation. Their stately growth and brilliant-colored leaves present an at tractive appearance when used for backgrounds or in the center of beds. H.H.A.

Caudatus (Love-Lies-Bleeding). Plants about 3 feet high, with long, drooping Pht. spikes of crimson flowers.

Tricolor splendens (Joseph's Coat). Superior to the old varicty; dazzling variegated foliage.

ANEMONE. Early spring-blooming plants with bright cup-shaped flowers. H.P. $1 \mathrm{ft}$.

Coronaria (Poppy Anemone). Finest mixed. .

St. Brigid. An improvement on the preceding, producing double and semi-double flowers of immense size and many colors.

\section{ANTIRRHINUM (Snapdragon)}

The Snapdragon seems to do well in almost all gardens, especially if planted in a sunny position, and from July until frost its long spikes of flowers are borne in endless profusion. For cutting, the tall varieties are recommended, while the dwarf sorts make fine plants for bedding. Seed sown in February and March will produce blooming plants by July.

\section{GIANT MAXIMUM ANTIRRHINUM (Height 3 ft.)}

\begin{tabular}{|c|c|c|}
\hline $\begin{array}{r}\text { Pkt. } \\
\text { so } 15\end{array}$ & Pkt. & White.......s \\
\hline pper King $\ldots \ldots \ldots \ldots \ldots$ & Ruby. Velvety red... & Finest Mixed. $1 / 40 \mathrm{oz} .60 \mathrm{cts}$ \\
\hline
\end{tabular}

Collection, one pkt. each of the 5 colors, 50 cts.

\section{GIANT-FLOWERED HALF-DWARF ANTIRRHINUM}

The half-dwarf Snapdragons are the finest of all for bedding and general garden planting. Growing about 18 inches high and blooming from July until frost, they afford fine cut-flowers all summer. Our mixture

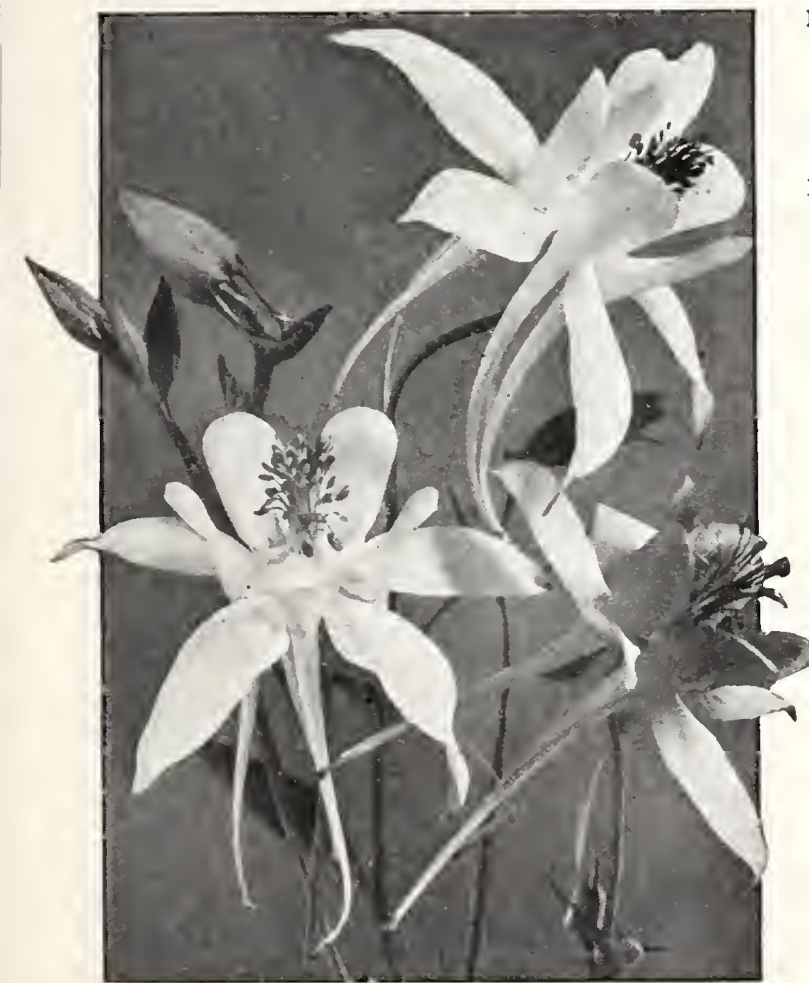

Aquilegia, Long-spurred Hybrids contains all the brightest and showiest colors.

Finest Mixed. Pht. $10 \mathrm{cts}, 1 / 4 \mathrm{oz} .40 \mathrm{cts}$.

\section{TOM THUMB ANTIRRHINUM} (Height 1 it.)

The best Snapdragon for borders and pot plants. Mixed. All colors. Pht. $10 \mathrm{ets.,1}$ 1́oz, 40 ets.

\section{AQUILEGIA}

One of our prettiest perennials, blooming in endless profusion from May until July. The odilshaped flowers are unique in appearance and borne on slender stems well above the foliage.

Chrysantha. Attains a height of 3 feet and Pkt.

has beautiful golden yellow flowers...... \$0 10

Cærulea. A variety of striking beauty;

flowers violet-blue and white. $2 \mathrm{ft}$.

Rose Queen. Long-spurred flowers, of a soft delicate rose-pink color, with white centers and vellow anthers. A charming and very pleasing color combination. 15 inches. .

Long-spurred Hybrids, Mixed. A wonderful mixture of large-flowered hybrids, comprising a great variety of colors in blue, white, yellow, pink, scarlet, and orange...........2 pkts. 25 cts...

Double Varieties, Finest Mixed

ARABIS alpina. Splendid little plants for edging, growing 6 inches high and covered with a mass of small white flowers in spring. H.P......... 1/4 oz. $30 \mathrm{cts}$.

ARCTOTIS grandis. This daisy-like annual is of easiest culture, blooms continuously until frost, and is splendid for cutting. Flowers white, reverse of petals palc blue. $21 / 2 \mathrm{ft} \ldots . . . \ldots \ldots 1 / 4 \mathrm{oz} .30 \mathrm{cts} .$.

\author{
10
} 15

15

10

10

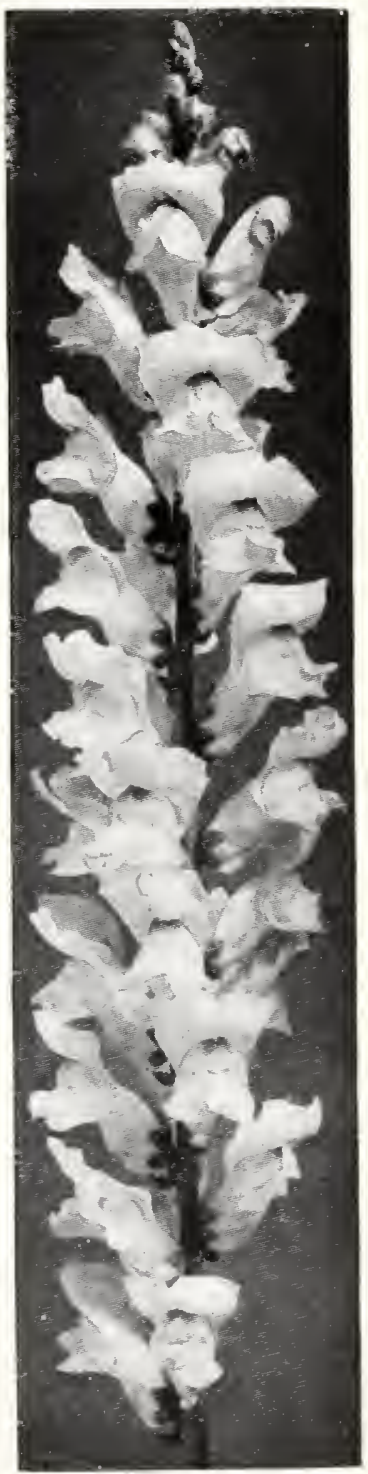

Antirrhinum 


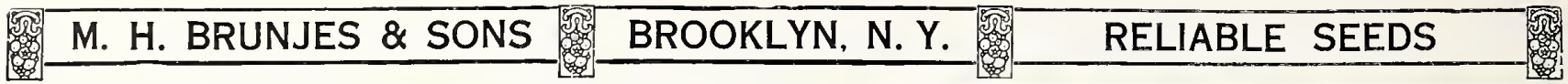

\section{Brunjes' Superb Asters}

The ever-increasing demand for this favorite flower sureiy proves its popularity with the florist and also for the home-garden. It has few superiors for cutting and ranks with the best annuals for bedding. For early flowers sow in frames during March and April, while for late-flowering, seed may be sown in the open ground in May. They prefer a sunny location, rich soil and, if possible, avoid planting them on the same place two years in succession. H.H.A.

\section{SIX KING ASTERS (INTRODUCTIONS)}

Everybody loves Asters, but we are sure the King Asters will more than please you. The flowers are of giant size and differ from other varieties in form as the petals are folded lengthwise, giving them a quilled effect. Be sure and try them.

Violet King. This famous variety is known the world over and no other flowers of immense size. Pkt. 10 cts., $\frac{1}{4} \mathrm{oz}$. $\$ 1$.

Crimson King. Another new variety of this grand Aster, which we are Crimson King. sure will prove equally as good and become just as popular as the two well-known varieties, Violet King and Rose King. The plants are strong and vigorous, of branching growth, and crowned with giant blooms of rich crimson. Pkt. 15 ets., 2 pkts. 25 cts.

Rose King. The stiff, strong petals of brilliant rose-pink are so formed as ities of the flower render it a most valuable sort for cutting. Pkt. $10 \mathrm{cts}$., $\frac{1}{4} \mathrm{Oz}$. $\$ 1$.

Lavender King. Flowers similar in every way to White King except in color, form, size and color. Pkt. 15 cts., 2 pkts. 25 cts.

White King. One of our largest and most valuable white Asters for cutting. soft, fluffy appearance, and their immense size and peculiar form make them strikingly handsome. Pkt. 15 cts., 2 pkts. 25 cts.

Pink King. A new shade in King Asters that will be welcomed by all lovers Pink King. of this class. Flowers of the same giant size and form as the preceding varieties, but in color a soft pleasing shade of blush-pink. Exception

ally pretty in bouquets whether alone or with some of the darker colors. Pkt. 15 cts., 2 pkts. 25 cts.

Mixture of King Asters. Pkt. 15 cts., 2 pkts. 25 cts.

Collection, one packet each of the $6 \mathrm{King}$ Asters, 60 ets.

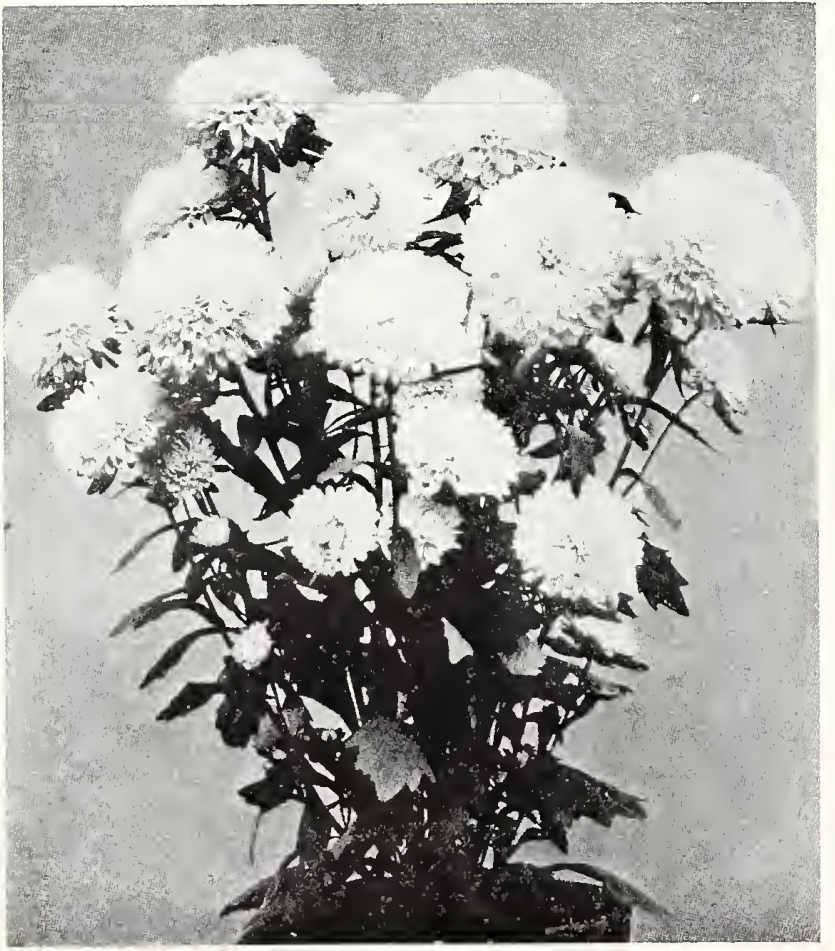

Giant Imperial Aster, Purity

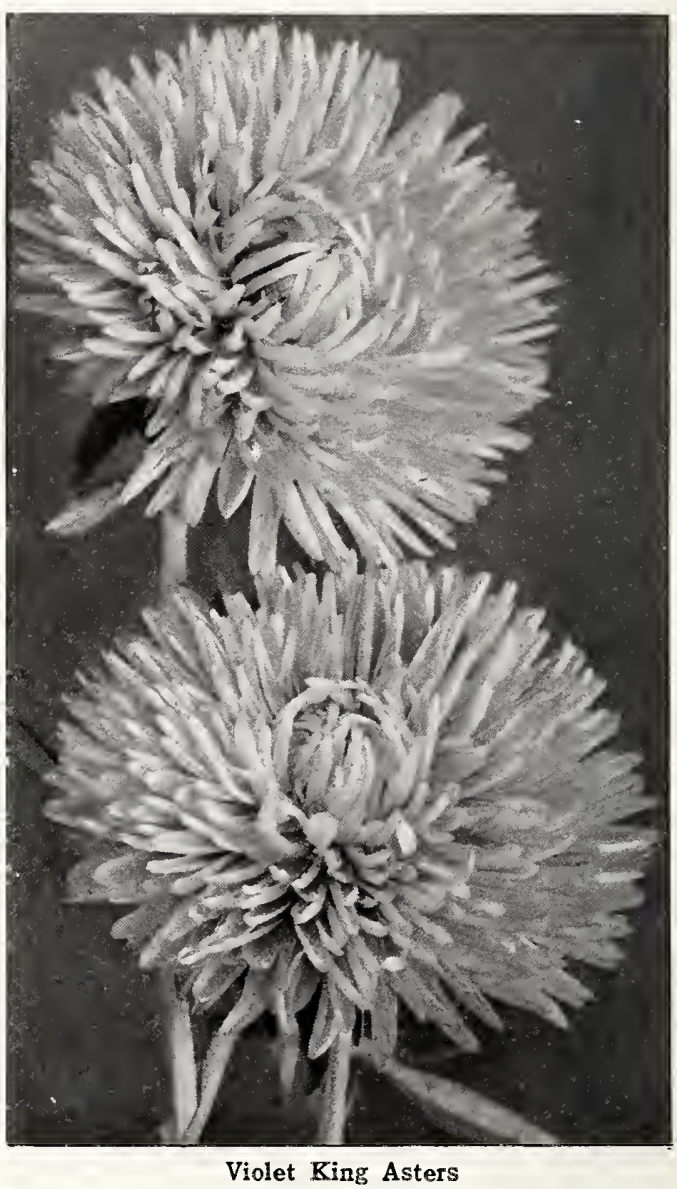

\section{GIANT IMPERIAL ASTERS}

These American Asters are greatly admired for their profusion of bloom and the doubleness of their flowers. They grow about 18 inches high and are especially adapted for massing and bedding purposes. Under good cultivation each plant bears from 40 to 50 large double flowers and we recommend them highly. Bloom in August.

Daybreak. Splendid early-blooming sort, having large, double, Pkt. 15 cts., 2 pkts. 25 cts.

Lavender Daybreak. A very popular and pleasing type of like those of the Daybreak and Purity. Plants strong, compact, and free-blooming. Pkt. 15 cts., 2 pkts. 25 cts.

Purity. Another magnificent Aster, similar in growth to Day$15 \mathrm{cts} ., 2$ pkts. 25 cts.

GIANT IMPERIAL MIXED. Pkt. 15 cts., 2 pkts. 25 cts.

\section{CAILIORNIA GIAN'TS}

A new midseason Astcr of the Comet type with exceedingly large fluffy flowers, measuring up to 6 inches in diameter, which are borne on strong stems 2 feet long. Their immensc size and beauty, long sturdy stems, and good lasting quality make them excellent for cutting.

Deep- Rose

Pkt.

Light Blue .

15

Peach Blossom

15

Purple.

15

White. 15

Collection, one packet each of the 5 colors, 50 ets. 


\section{H. BRUNJES \& SCNS BROOKLYN, N. Y.}

\section{FOUR PRIZE - WINNING ASTERS}

Violet King. This famous variety is known the world over, and no other Pkt. $10 \mathrm{cts}$., $\frac{1}{4} \mathrm{oz} . \$ 1$

California Giant White. Large, fluffy flowers of the Comet type, borne Creely on long stems and as pretty as any chrysanthemum. Especially fine for cutting. Pkt. 15 cts., 2 pkts. 25 cts.

Heart of France. The best and one of the loveliest dark red Asters ever about 2 feet high, and begin blooming late in August. Large, full, double flowers produced on long stems, are rich ruby-red in color and retain their brilliancy and luster for a long period. Pkt. $15 \mathrm{cts} ., 2 \mathrm{pkts} .25 \mathrm{cts}$

Peerless Pink. A beautiful shell-pink Aster with unusually large, globular free-blooming plants, about 2 feet high, are of robust growth and branching
habit. Pkt. 15 cts., 2 pkts. 25 cts.

Collection, one packet each of the above 4 varieties, $45 \mathrm{cts}$.

\section{NEW ROYAL ASTERS}

For a medium-early. large-flowered Aster try this new variety. In size and appearance the flowers resemble our Late Branching and like that variety it is sure to become very popular both with the florist and private gardener.

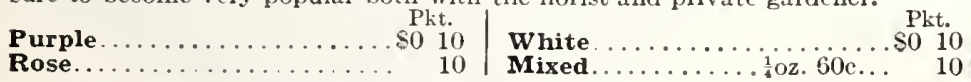
Collection, one packet each of the 3 colors, 25 cts.

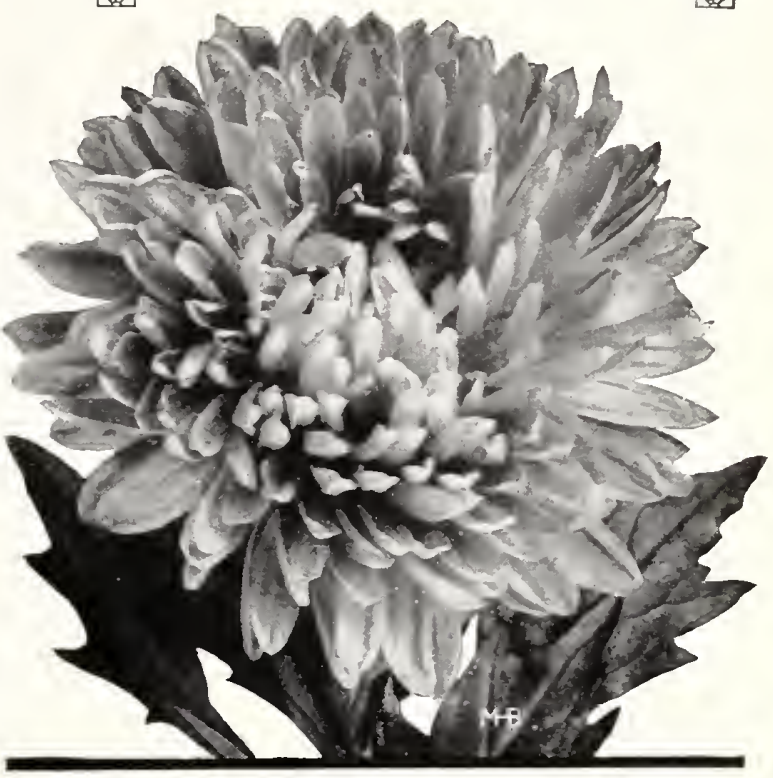

Late Branching Aster

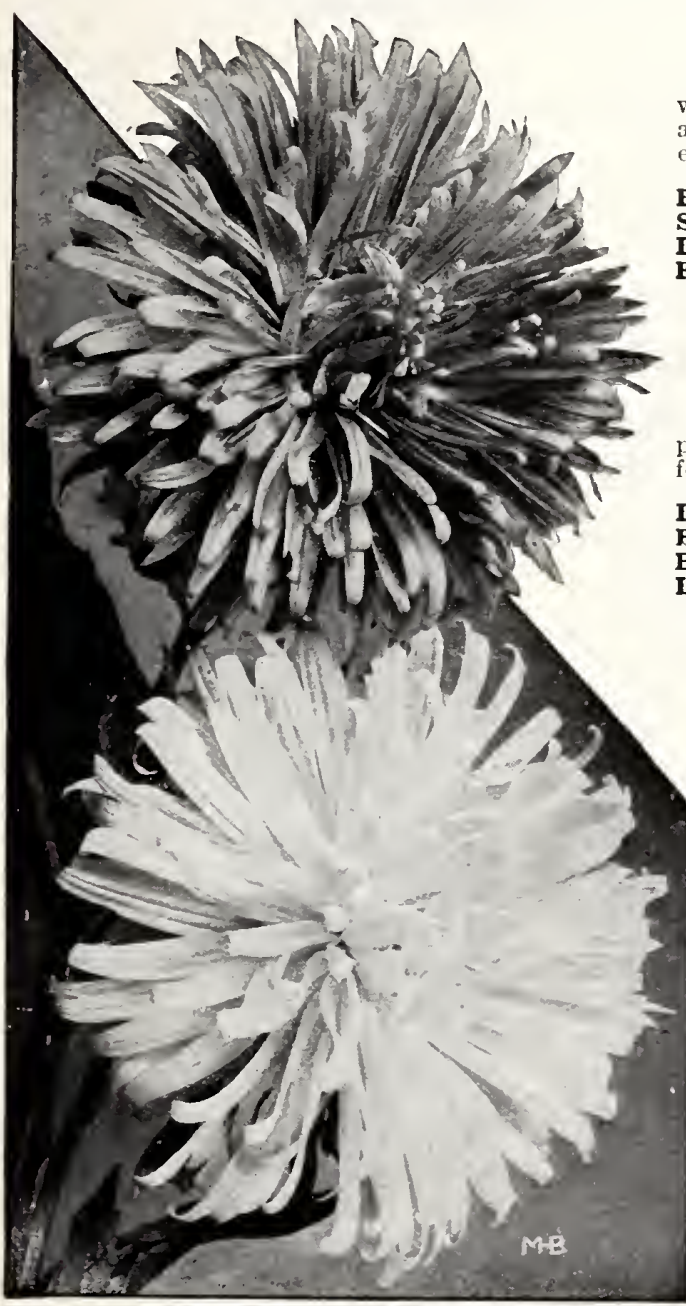

Crego's Giant Comet Asters

\section{LATE BRANGHING ASTERS}

There is no Aster more popular or so largely grown for late blooming as this well-known variety. The plants grow from 2 to $2 \frac{1}{2}$ feet high, are strong, well-branched and continue to bloom from the latter part of August until late in fall. The flowers are extra-large, beautifully formed, and borne on stiff stems, 15 to 20 inches in length.

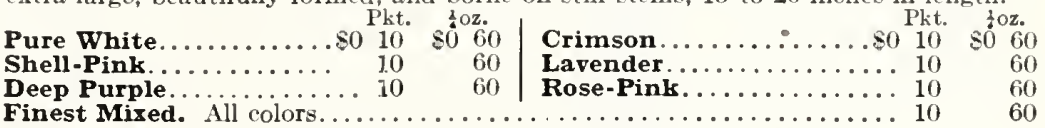

Finest Mixed. All colors. .............................. $10{ }^{6}{ }_{60}$

Collection, one packet each of the 6 colors, $40 \mathrm{cts}$.

\section{QUEEN OF THE MARKET}

This is one of the earliest Asters grown. The plants are of branching habit and produce flowers of rather large size and quite full to the center, which are splendid for cutting. Height 15 inches.

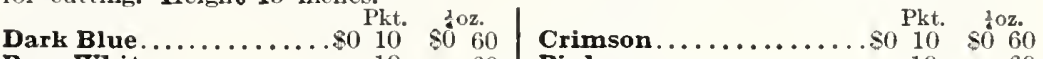

Pure White............... 10 60 60 Pink ....................

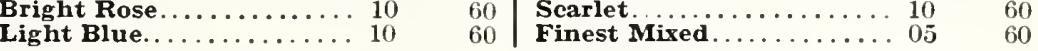

Collection, one packet each of the 7 colors, $50 \mathrm{cts}$.

\section{GREGO'S GIAN'T GOMET}

Undoubtedly the finest of all loose-petaled or feathered Asters, producing flower: of extra-large size, 4 to 5 inches across, which keep longer when cut than most varieties of this type. Ideal for cutting. $2 \mathrm{ft}$.

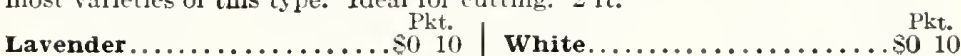
Crimson................. 10 Purple................... 10

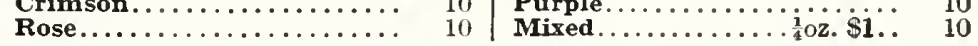
Collection, one packet each of the 5 colors, 40 cts.

\section{AMERICAN BEAU'TY}

The flowers are full and double, 4 to 5 inches in diameter, with incurved petals smilar to those of the popular Late Branching variety. Plants of branching habit grow $21 / 2$ feet high and begin blooming the end of september; a valuable Aster for late cutting.

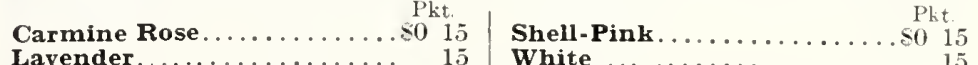

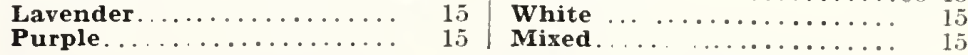

Collection, one packet each of the 5 colors, 50 cts.

Our Aster Seed is grown by the best American and European 33 


\section{VICTORIA ASTERS}

Our strain of Victoria Aster is very fine, and we recommend it highly as one of the best for the garden. The plants are of pyramidal growth, about 18 inches high, and are covered with large, extra-double flowers.

Finest Mixed.

$\frac{1}{4}$ Oz. $75 \mathrm{c} . . \$ 0 \mathrm{Pkt}$.

ASTERS, CROWN, or COCARDEAU. The white-centered flowers are bordered with various brilliant colors. Very attractive. $1 \frac{1}{2} \mathrm{ft}$.

Finest Mixed.

ASTERS, DWARF, Chrysanthemum-flowered. For bedding, edging, and pot culture, this large-flowered, late-blooming variety is one of the best. Grows about 1 foot high.

Finest Mixed.

$\frac{1}{4} \mathrm{oz} .75 \mathrm{c}$.

ASPARAGUS plumosus nanus. Very popular decorative plant, with graceful, feathery, fern-like foliage. A splendid pot-plant for the conservatory

Sprengeri. Just the plant for hanging-baskets, either for the house in winter or the porch in summer. Its drooping foliage is coarser than that of the $A$. plumosus nanus. $4 \mathrm{ft} . \ldots . \ldots . . . .10$ AUricula. See Primula.

BALLOON VINE. For covering fences and porches try this quickgrowing annual climber. The balloon-like seed-pods which follow the small white flowers are very interesting as well as attractive. $8 \mathrm{ft}$..

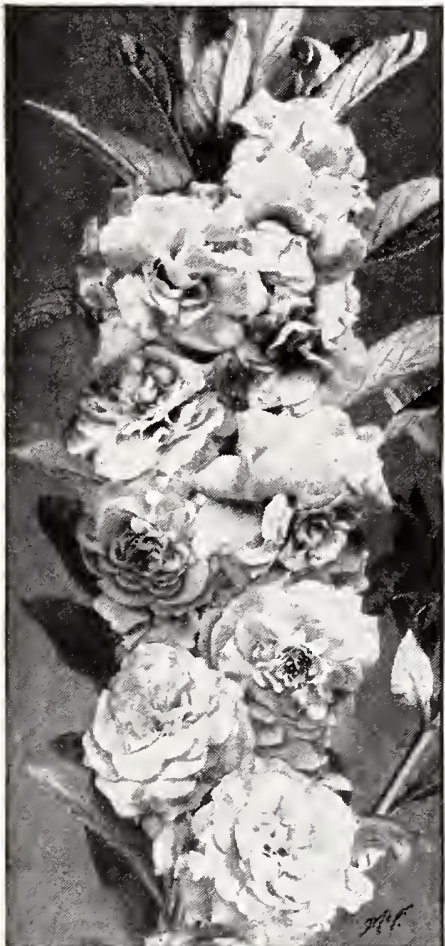

Double Rose-flowered Balsam

\section{BALSAM (Lady's Slipper)}

Very popular and exceedingly beautiful plants for massing in the flower-garden during the summer months. They produce gorgeous clusters of large, double, wax-

like flowers abundantly in all shades of

color from white to crimson. This old-time favorite is so casy to grow and blooms so freely that one or more packets should be included in every order. H.H.A. $2 \mathrm{ft}$.

Double Rose-flowered. Handsome double flowers; plants 18 inches high. Mixed colors...... Pkt.

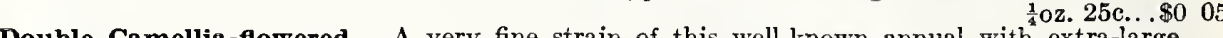

Double Camellia-flowered. A very fine strain of this well-known annual with extra-large,

double flowers, including many beautiful striped and spotted ones. Finest mixed... $\frac{1}{4}$ oz. $30 \mathrm{c}$. 05

BALSAM APPLE and PEAR. See Momordica.

\section{BEGONIA Fibrons-rooted}

The Begonia is one of the leading and most popular summer-flowering plants for bedding, and from June until late fall is an endless mass of bloom. Sow seed in January and February.

Gracilis luminosa. Large, fiery, dark scarlet Pkt. flowers; bronze foliage. Splendid bedder .....\$0 20 Semperflorens rosea. Rosy pink............ 10 Semperflorens, Vernon. Red; bronze foliage.... 10 BELLIS. See Daisy.

\section{GALLIOPSIS}

Favorite free-flowering annuals requiring no particular attention but thriving best in sunny locations. The tall varieties are splendid for cutting, and from seed sown in early spring you will have an abundance of flowers throughout the summer and early fall. Bright, showy flowers in yellow, brown, and crimson. Sow seed in early spring where plants are to remain.

Atrosanguinea. Dark crimson. $2 \mathrm{ft}$..

Pkt.

$\$ 005$

Coronata maxima. Showy, large yellow flowers, especially fine for cutting

Drummondii (Golden Wave). Compact bushes are completely covered with bright golden

yellow, dark-centered flowers. Very pretty border plant, also. Exceedingly effective when

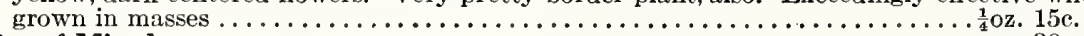

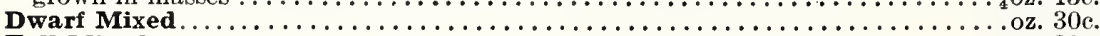

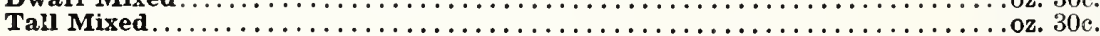

\section{GALENDULA (Pot Marigold)}

One of the brightest yellow-flowered annuals, thriving in almost any soil and producing on stout stems, large, double flowers of every known shade, from the lightest yellow to the deepest orange. $1 \mathrm{ft}$. H.A.

Orange King. Specially selected strain largely used by florists for cutting. Flowers very double and of a rich, glistening orange.......................... $50 \mathrm{c}$.

Ball's Orange. The rich golden orange flowers of this beautiful variety are extra large,

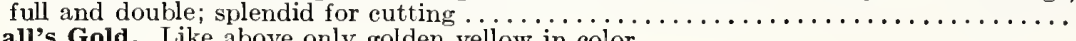

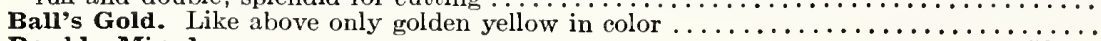

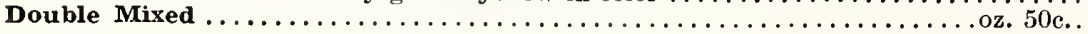

$\mathrm{Pkt}$.

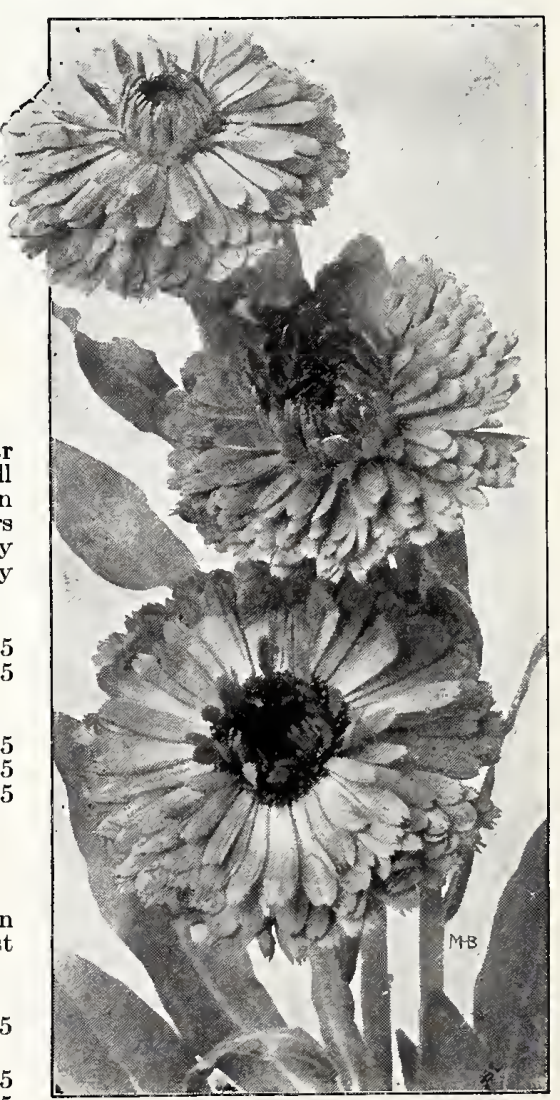

Orange King Calendula 


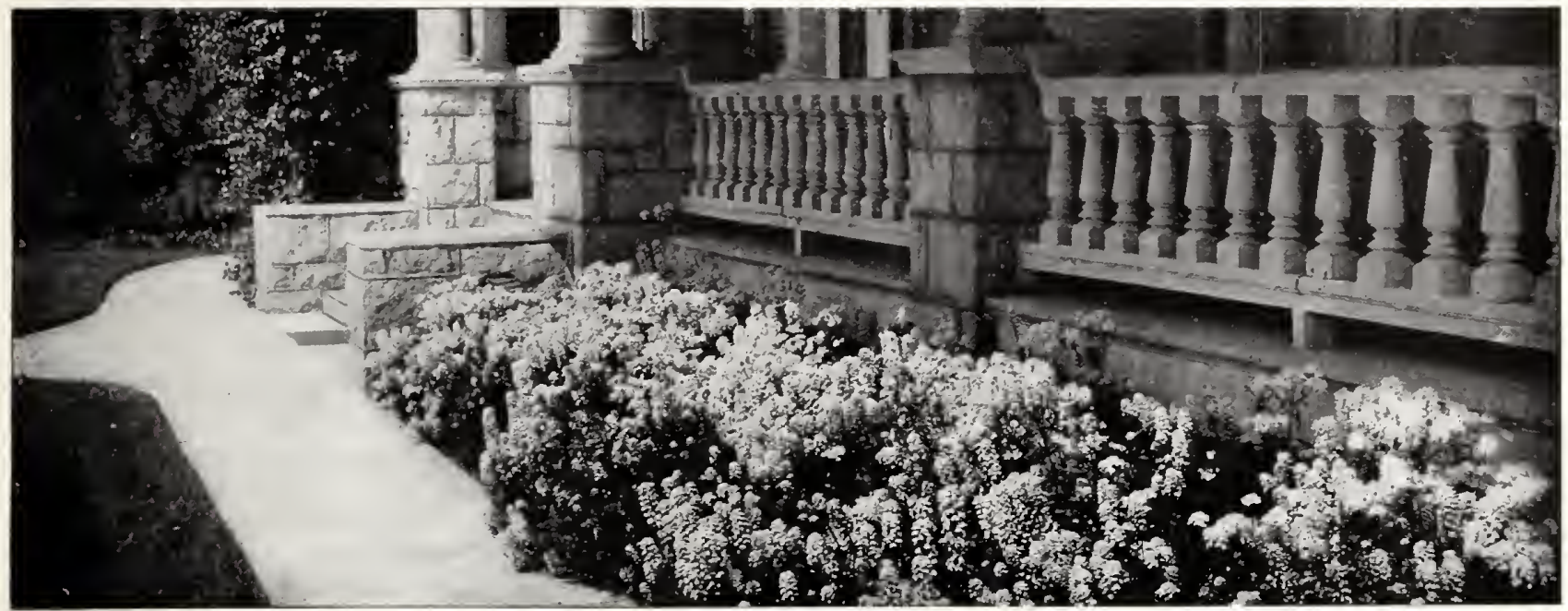

Candytuft, Empress

GAMPA NULA (Bellflower)

There are quitc a number of old-fashioned flowers, but this one scems to be a favorite with all. The blue and white bell-shaped flowers, blooming as they do in such great profusion, always attract attention. H. P.

Persicifolia (Peach Bells). A grand variety having large bell- Pkt. or cup-shaped blossoms. $2 \frac{1}{2} \mathrm{ft}$

Finest Mixed. Blue and white.

Pyramidalis. The handsome showy flowers a........... stems about 5 feet high.

Blue .

White.

Finest Mixed.

\section{GANTERBURY BELLS}

(Campannla Medium)

Admirably adapted for borders, beds, or massing, and their countless number of beautiful flowers may be enjoyed during a long period. H. B. $2 \mathrm{ft}$.

Single Blue.

Single Rose

Single Striped

Single White.

Finest Single Mixed.

Finest Double Mixed.

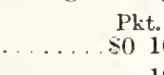
so 10 . 10 10 10

Calycanthema (Cum and Saucer). The flowers of this interesting class of Canterbury Bells are not unlike a cup and saucer in appearance. They arc very attractive, easily grown, blooming the second year from seed. Single plants will of ten have fifty or more flowers open at one time.

Finest Mixed......pkt. $10 \mathrm{cts} ., \frac{1}{4} \mathrm{oz} .50 \mathrm{cts}$.

CANARY BIRD FLOWER. Sce Tropæolum.

CALCEOLARIA. Gorgeous greenhouse plants with magnificent striped, mottled and self colored flowers of striking beauty. Sow seed during June or July. H. H. B. $2 \mathrm{ft}$.

Grandiflora, Finest Mixed. Tigered Pkt. and self-colored..............\$ $\$ 25$

\section{CANNA}

Few plants surpass the Canna for centerpieces or bedding. Sow seed early indoors.

Crozy's Large-flowering. Fine Mixed so 10

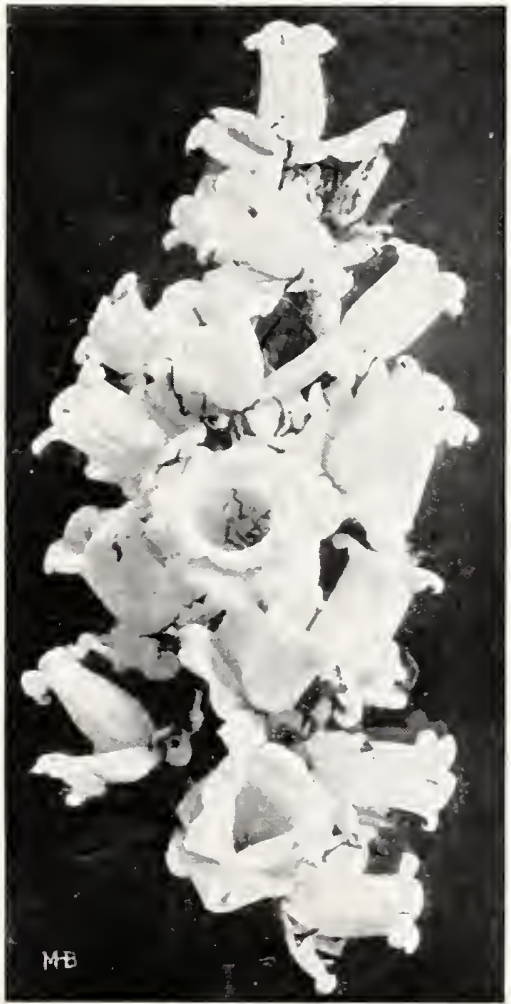

Campanula Medium (Cup and Saucer)

\section{GANDYTUFT}

Like alyssum, this hardy annual begins to bloom very carly, and if several sowings are made at intervals, a supply of flowers may be had all summer. Almost any garden soil is suitable for Candytuft but a sumy position is preferred. The white-flowered varieties, Empress and Giant Hyaeinth-flowered, are grown extensively by florists for cutting. Our stock of both is very fine.

Giant Hyacinth-flowered. Splendid for cutting; flowers of Pkt.

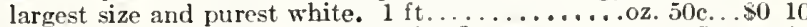

Empress. Large heads of snow-white flowers......... oz. 50c... 10 Finest Mixed. All colors, including white, flesh-color, carmine, crimson, and lilac....................................... 05 Dwarf Hybrids Mixed. Finc for borders. 6 in....1/4oz. 25c... 10

\section{Hardy Candytuit} (Iberis sempervirens)

Dwarf-growing plants blooming in spring; suitable for borders and rockwork; white Howers. $1 \mathrm{ft}$. Pkt. $10 \mathrm{cts}$.

\section{GARNATIONS}

Popular free-blooming plants, growing from 12 to 18 inches high and bearing large, double, rieh-colored flowers. H. H. P.

Giant Marguerite. A giant type of the Pkt.

Marguerite Carnation, admired for its

fragrance and producing a large per-

centage of double flowers. Mixed

colors........................ so 15

Chabaud's Earliest Perpetual. Hand-

some, large-flowercd strain, equally de-

sirable for house culture in winter or the

garden in summer. Finest Mixed....... 15

\section{MA RGUERITE GARNATIONS}

A favorite variety for starting early, cither in February or Mareh, when it will bloom eontinuously all summer. The delightfully fragrant flowers are splendid for cutting. The plants begin to bloom in four months after -owing the seed. Double Mixed

${ }_{\frac{1}{4}} \mathrm{oz}, 40 \mathrm{c} . . \$ 0 \mathrm{Pkt}$.

\section{HARDY GARNATIONS}

Sow seed of the hardy varieties during June or July and later transplant where they are to remain. This gives them ample time to develop into strong plants that will keep over winter with but slight protection.

EARLY DWARF VIENNA. Plants not Pkt.

over 1 foot high and often fifty flowers

have bcen counted on one bush.

Double Finest Mixed...... $\frac{1}{4}$ oz 75 c.. .\$0 10 Grenadin. Double bright scarlet. 


\section{H. BRUNJES \& SONS}

\section{GELOSIA}

Altogether a very ornamental class of plants, some with large, ruffled heads, resem bling a cock's comb and others with beautiful feather-like plumes. When well grown, the Cristata varieties are exceedingly handsome, while few flowers are more picturesque than the brilliant feathered sorts. H.H.A.

\section{GRISTA TA (Gockscomb)}

Glasgow Prize. Splendid dwarf variety of immense size and rich crimson Pkt.

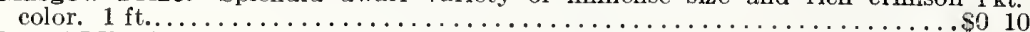
Dwarf Mixed

\section{FEATHERED VARIETIES}

THOMPSONII MAGNIFICA. An exceptionally fine strain with large spikes of magnificent, plumed flowers which remain in bloom an unusually long time. They make excellent plants for bedding and their brilliant-colored plumes form a striking contrast to the rich, green foliage. 2 to $-3 \mathrm{ft}$.

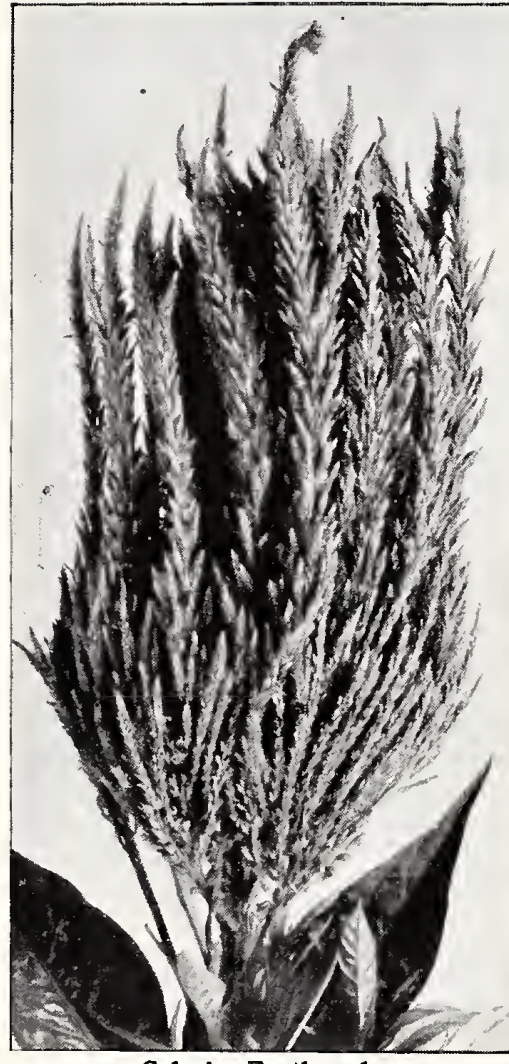

Celosia, Feathered

Crimson ................... 10

Golden Yellow. . . . . . . . . . . 10

Finest Mixed. . . . . . . $40 . .10$

\section{Pride of Castle Gould}

A superior strain of Celosia, admired for its large, feathery plumes, which vary in color from the deepest blood-red to carmine, salmon, orange and yellow. Very decorative when grown in pots, and most valuable for bedding, blooming from August until frost. Seed sown in March makes fine plants for setting out in May. 2 to $3 \mathrm{ft}$. Mixed colors. Pkt. $15 \mathrm{cts}$., 2 pkts. 25 cts.

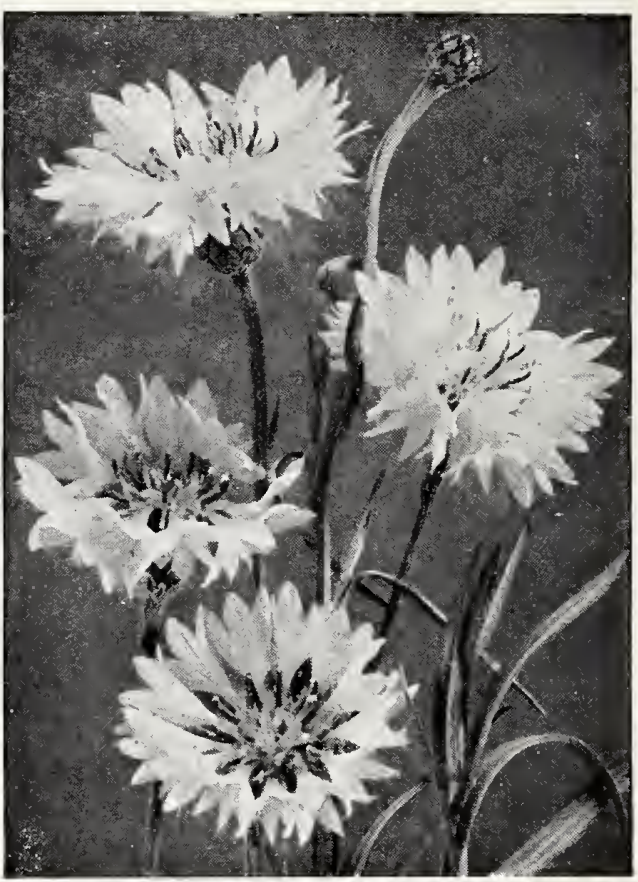

Centaurea Cyanus. Cornflower

\section{CEN'TA UREA}

Hardy annuals, of easiest culture, bearing long-stemmed, bright-colored flowers, which are favorites both for the garden and as cut-flowers. The common Cornflowers (Centaurea Cyanus) are most desirable for the old-fashioned and wild flower gardens. $2 \mathrm{ft}$.

\section{GYANUS (Gornflower)}

Single Blue. Finest blue for cutting. Double Blue. Very fine for cutting.

Double-

\section{GIANT SWEET SULTANS}

These giant Cornflowers are indispensable for cutting and vase decoration. Their sweet-scented flowers are borne on long, stout stems and average 3 to 4 inches in diameter. $2 \mathrm{ft}$. Pkt. IMPERIALIS alba. An excellent white variety for cutting........\$0 10 Finest Mixed ................ 10

\section{CHRYSAN'THEMUM}

Splendid single and double annuals, the flowers of which are quite large and very effective in bouquets. The plants, 2 feet high, are easily raised from seed and deserve a place in every garden.

\section{ANNUALS}

Carinatum, Single Mixed

..................

Carinatum, Double Mixed Pkt. Morning Star. Early, profuse-blooming plants with large, daisy-like flowers, borne on strong stems and of a beautiful cream-yellow color. $1 \frac{1}{2} \mathrm{ft}$. . $^{\frac{1}{4} \mathrm{Oz} .} 15 \mathrm{c} . \ldots$ Evening Star. Rich golden yellow flowers, 3 inches across; very fine for cutting. Grows about $1 \frac{1}{2}$ feet high. . This garden gem is crowned with small, double,
Inodorum plenissimum. nodorum plenissimum. This garden gem is crowned with small, double,

\section{PERENNIALS}

Frutescens (Margucrite, or Paris Daisy). White, star-shaped flowers; a desirable pot-plant for winter blooming. $1 \frac{1}{2} \mathrm{ft}$.

Shasta Daisy. An clegant hardy perennial, about $2 \frac{1}{2}$ feet high, bearing longstemmed, single, white flowers 10
Pkt.

05

05

05

\section{WHIT E-LEA VED}

\section{GENTAUREAS (Dusty Millere)}

For borders and ribbon beds these whiteleaved plants are very useful and exceedingly attractive. $1 \mathrm{ft}$. Pkt. Candidissima. Silvery white foliage. $\$ 010$

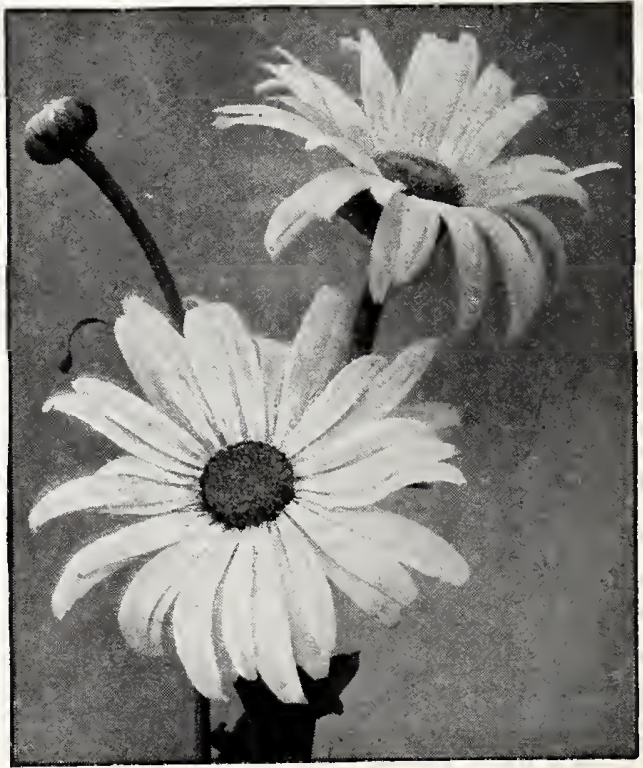

Chrysanthemum. Shasta Daisy 


\section{H. BRUNJES \& SONS}

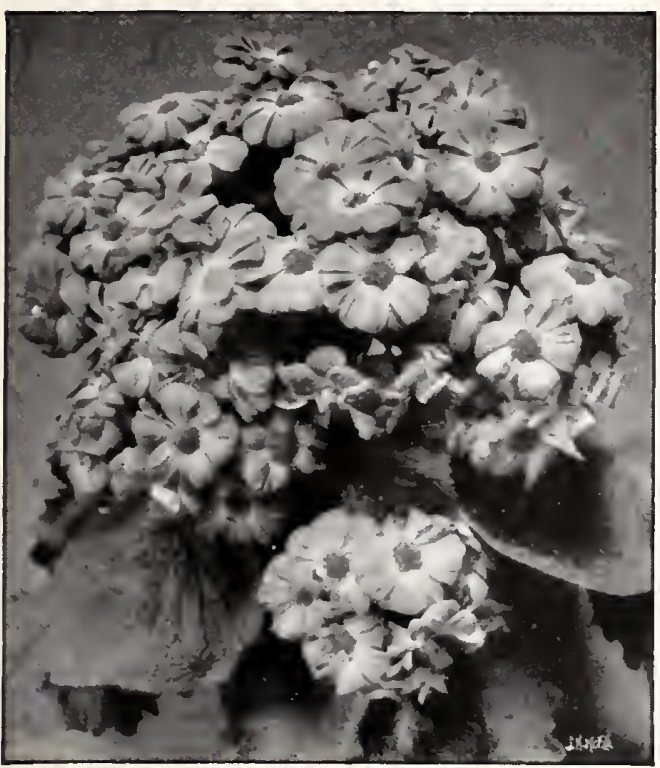

Cineraria, Brunjes' Giant-flowering

\section{CINERARIA}

The Cineraria is one of the most beautiful of greenhouse plants and during the spring months, just about Eastertime, they are usually seen at their best. Unlike that of most grcenhouse plants the sced of Cineraria germinates rearlily and if somin in July and August, preferably the former, nice plants may be had for early spring blooming. $1 \frac{1}{2} \mathrm{ft}$.

Brunjes' Giant-flowering Mixed. Ourstrain has been saved from Pkt. individual blooms often measuring 3 inches aeross, of excellent substance and most exquisite and varicd eolors.

Large-flowering Dwarf Mixed. The fincst dwarf-nrowing variety; remarkable alike for its large size and riehly colored flowers. $10 \mathrm{in.}$

Maritima. Like the white-leaved ("entaurcas (Dusty" Millers) this variety is very useful for edging and ribbon borders. It grows about 2 feet high and has silvery white foliage. Sow seed indoors during March...... $\frac{1}{4} \mathrm{oz} .20 \mathrm{c} . .05$

CLARKIA. Showy annual growing about 2 feet high and blooming profusely throughout the summer.

Mixed. Double and single Varieties.

\section{CLEOME pungens (Spider}

Plant). An interesting
plant, inasmuch as the
rose-colored flowers are
spider-like in appearance.
Of strong growth and
blooms profusely through-
out the summer. Sow
seed in doors during
March. Tender an- Pkt.
nual. 3 ft......... so 05

СОВ $\boldsymbol{E A}$. Very pretty, rapid-climbing plant, blooming freely the first season, and attains a height of 15 to 30 feet. It clings readily to any rough surfaee, and is splendid for trailing along the porch or veranda. The large, handsome foliage makes a beautiful background for the purple and white bell-shaped flowers. Tender perennial.

Scandens. Purple bell-shoped flowers........................

Scandens alba. White.

\section{GONVOLVULUS (Morning-Glory)}

\section{GLIMHING VA RIETIES}

There are ever so many climbers, one more beautiful than the other, but the grand old Morning-Glory still leads in popularity. The sced should be sown outdoors in

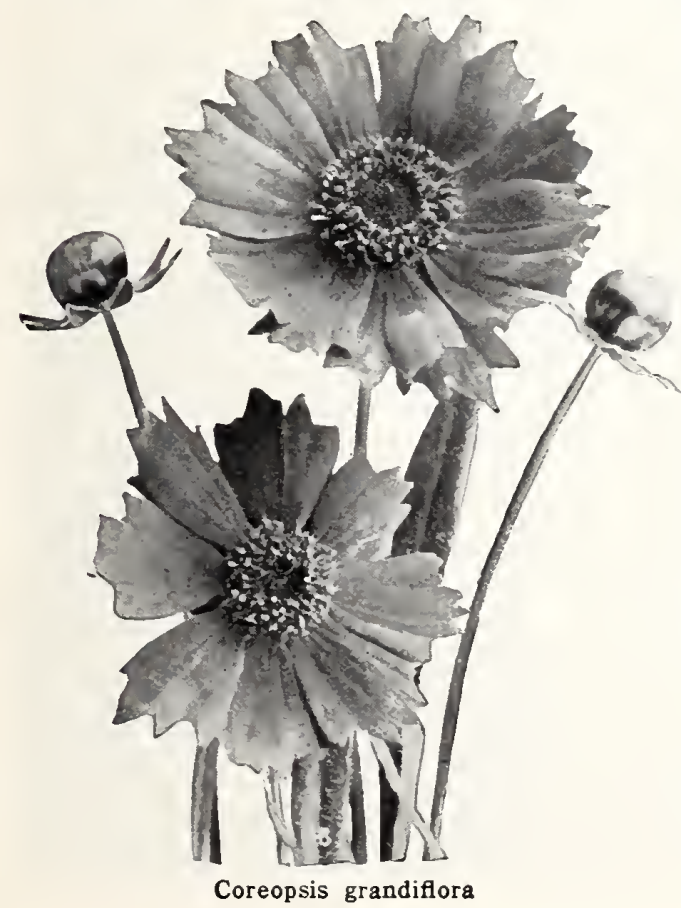
May, where the plants are to bloom, and they usually resow themselves.

Finest Mixed (Morning- Pkt. Glory). Our mixture includes many colors, as white, pink, dark red, striped and all shades of blue and purple........... $15 \mathrm{c} \ldots .8005$ Imperial Japanese. This is the finest of all Morn-

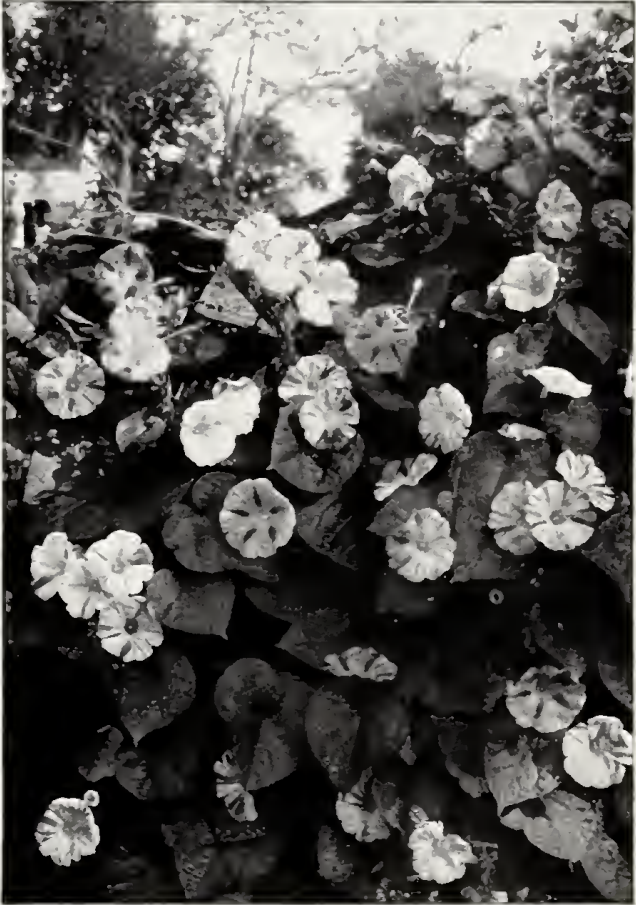

Morning-Glory, Imperial Japanese ing-Glories. The hand-

some variegated and mottled foliage, together with the large and beauti- Pkt. ful flowers, marked with exceedingly striking colors, forms an attractive

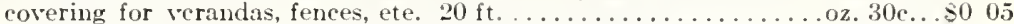

Dwarf Morning-Glories. Unlike the climbing varieties, the bushes grow but one foot high, and the flowers usually remain open all day. Mixed colors. oz. 15c.. 05

COLEUS. An ornamental foliage plant, so often used for edging beds of cannas and salvias. The various-eolored leaves are almost velvet in appearance. Start seed indoors during March and April. Mixed

COREOPSIS grandiflora. From carly summer until fall this hardy perennial is in constant bloom and the long-stcmmed, bright golden yellow flowers are excellent for cutting............................... $25 \mathrm{c} \ldots$ CORNFLOWER. See Centaurea.

\section{Chinese Woolflower (Celosia Childsii)}

We are quite sure you will like the Chinese Woolflower as it is easy to grow, blooms throughout the summer until killed by frost and is suitable either for beds, borders, or as individual spccimens. The plants grow about 3 fcet high, eaeh branch terminating in a bright red flower appearing like a ball of wool. Pkt. 15 cts., 2 pkts. $25 \mathrm{cts}$. 

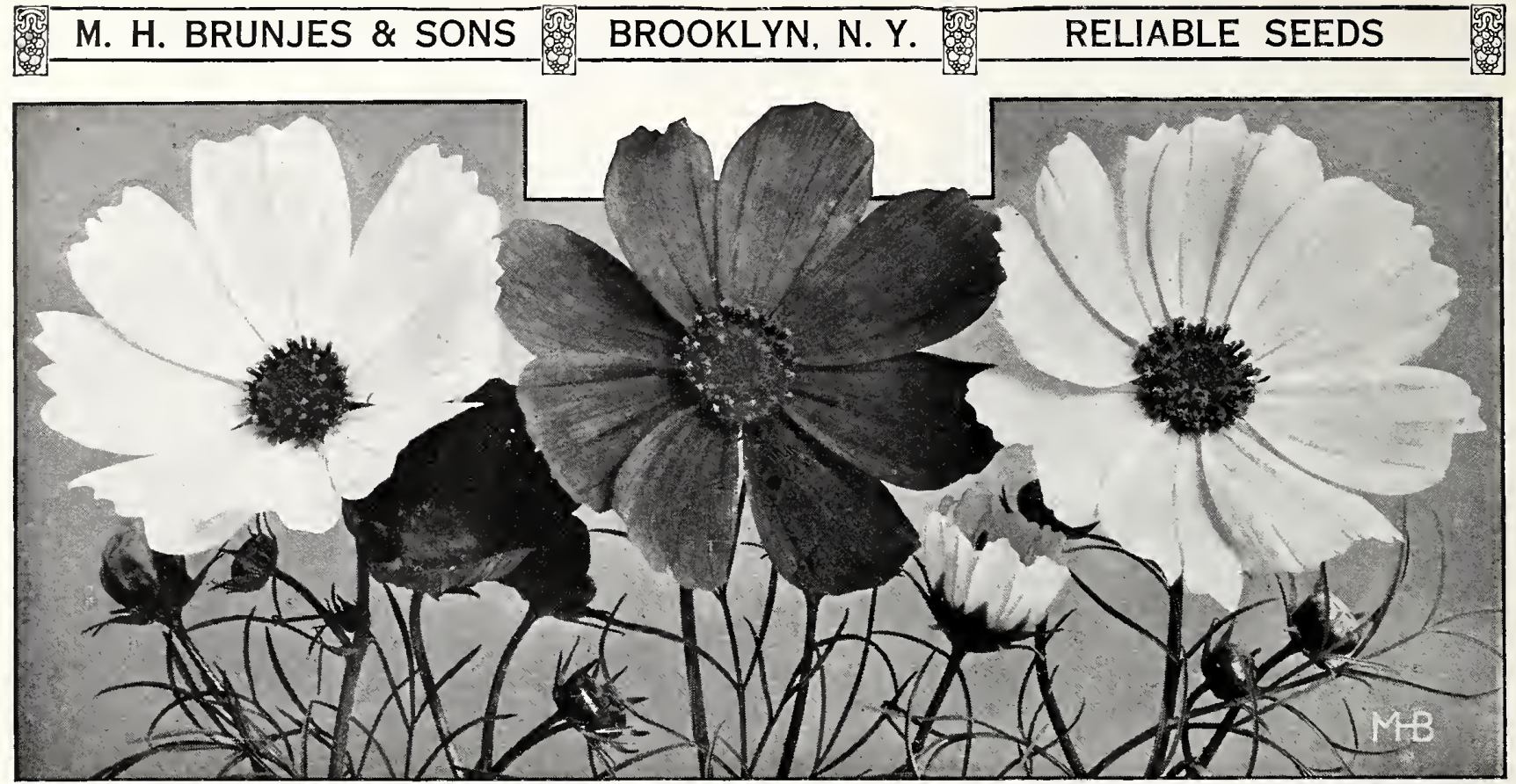

Mammoth Perfection Cosmos

\section{GOSMOS}

During the fall months, when most flowers are through blooming, the Cosmos appears in all its glory. The strong, sturdy plants, from 4 to 6 feet high, form splendid backgrounds and are literally covered with hundreds of large, single, dahlia-like flowers. Ideal for cutting and decorating, the fine-cut feathery foliage and bright-colored flowers contrasting to peffection. H.A.

\section{MAMMOTH PERFEGTION}

The flowers of this superb strain are of gigantic size and exceptional beauty. Sow the seed outdoors in May, or preferably under

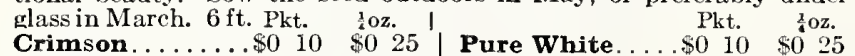
Bright Pink....... $10 \quad 25 \mid$ Mixed........... $10 \quad 20$

Klondyke. Should be started early to obtain blooming plants;

golden yellow flowers, 2 to 3 inches across............. 10

\section{EARLY DOUBLE-CRESTED GOSMOS}

A lovely addition to the Cosmos family, and one that will be welcomed by flower-growers everywhere. They are easily grown, and the flowers are unique in having a raised central crest of small petals which completely cover the disc. About 60 per cent come double. Mixed Colors. Pkt. 15 ets., 2 pkts. 25 cts.

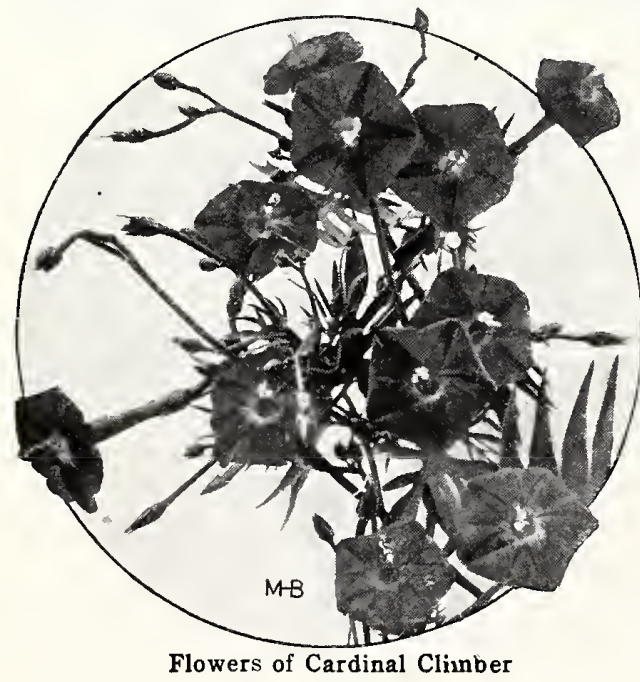

\section{LARGE EARLY.FLOWERING GOSMOS}

The dwarf, early-flowering Cosmos is becoming very popular, and while the flowers are not so large as the Mammoth strain, they appear at least a month earlier. $4 \mathrm{ft}$. Pkt.

Pink...............\$ 10 Crimson ............\$0 10 White (Dawn) ......... 10 Mixed.......... ${ }_{4} \mathrm{oz} .25 \mathrm{c} . .10$ CUPFEA platycentra (Cigar Plant). Very fine plants for pots and borders, about 1 foot high, continuing in bloom until fall.

Scarlet and purple, tube-shaped flowers. H. H. P.......... 10

\section{CYPRESS VINE (Ipomoea Quamoclit)}

A splendid annual climber for covering arbors, trellises, etc. The bright star-like blossoms of scarlet and white appear in endless profusion and with the delicate, feathery foliage form a very charming cffect. Grows 12 feet high. Mixed colors. Oz. 30 cts., pkt. 5 cts.

\section{THE GARDINAL CLIMBER}

A most beautiful anual climber of rapid growth, blooming profusely from midsummer until frost. The vines easily grow 20 to 30 feet high and the fine, fern-like foliage is literally covered with dazzling, fiery red tubular flowers which measure about $1 \frac{1}{1}$ inches in diameter. Prefers a warm, sunny location and should be sown in pich soil. Do not fail to try it. Plit. 15 cts., 2 pkts. 25 cts.

\section{GYCLAMEN}

The Cyclamen is among the prettiest of winter-blooming plants, possessing handsome foliage and magnificent, rich-colored flowers. From September to February is considered the best time to sow the seed, which will produce blooming plants in about one year. Giant-Flowering, Mixed........\$ $\$ 025$

\section{DAHLIA}

Though Dahlias are more largely grown from bulbs, they may also be raised from seed and if sown during March (indoors) they will bloom the first season. H.H.P.

Double Large-Flowering, Mixed \$0 Double Cactus, Mixed ............ 10 Double Decorative............... 10

\section{DIDISCUS CAERULEA}

\section{Blue Lace Flower}

A pretty annual growing about 18 inches high. Lavender-blue flowers. Pkt. $10 \mathrm{cts}$.

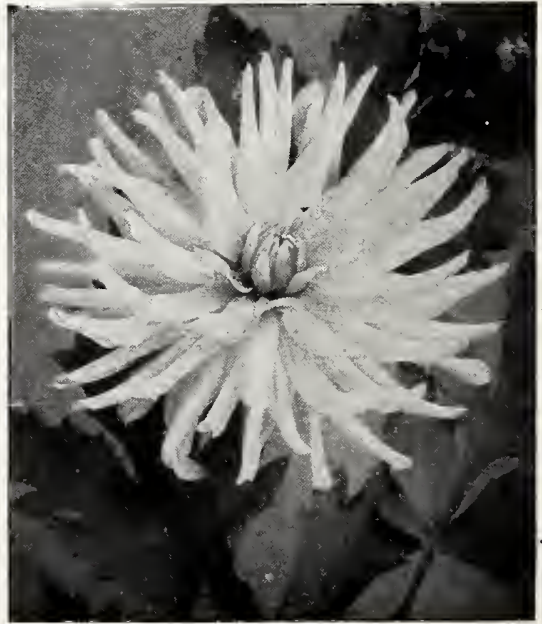

Cactus Dahlia 


M. H. BRUNJES \& SONS

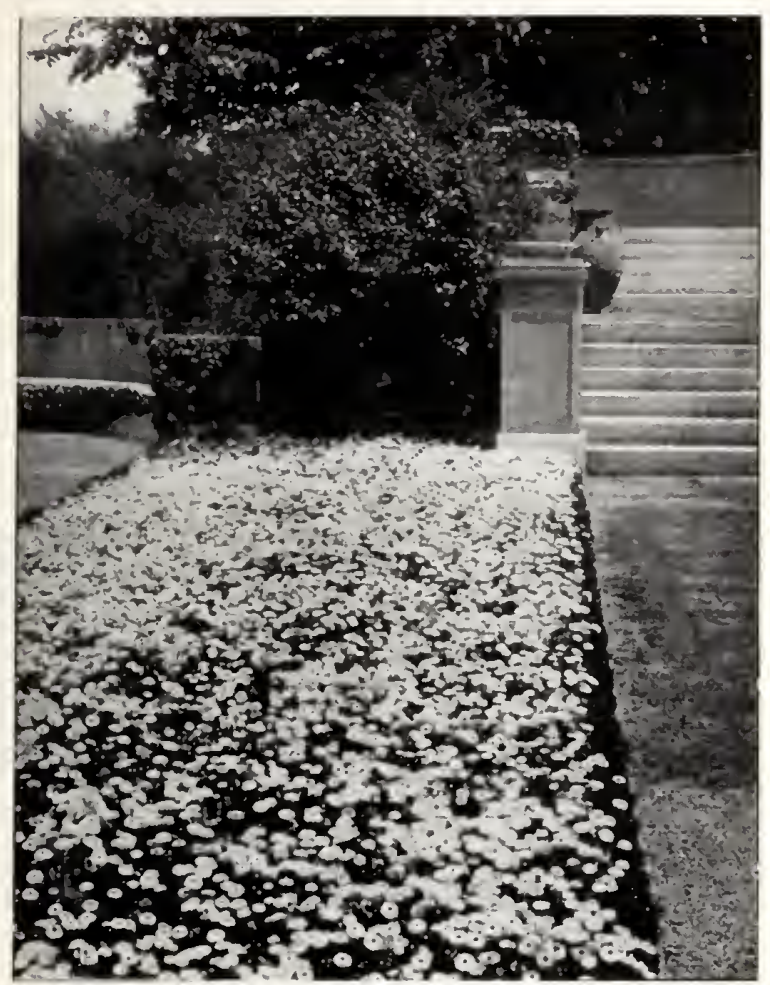

Daisies (Bellis perennis)

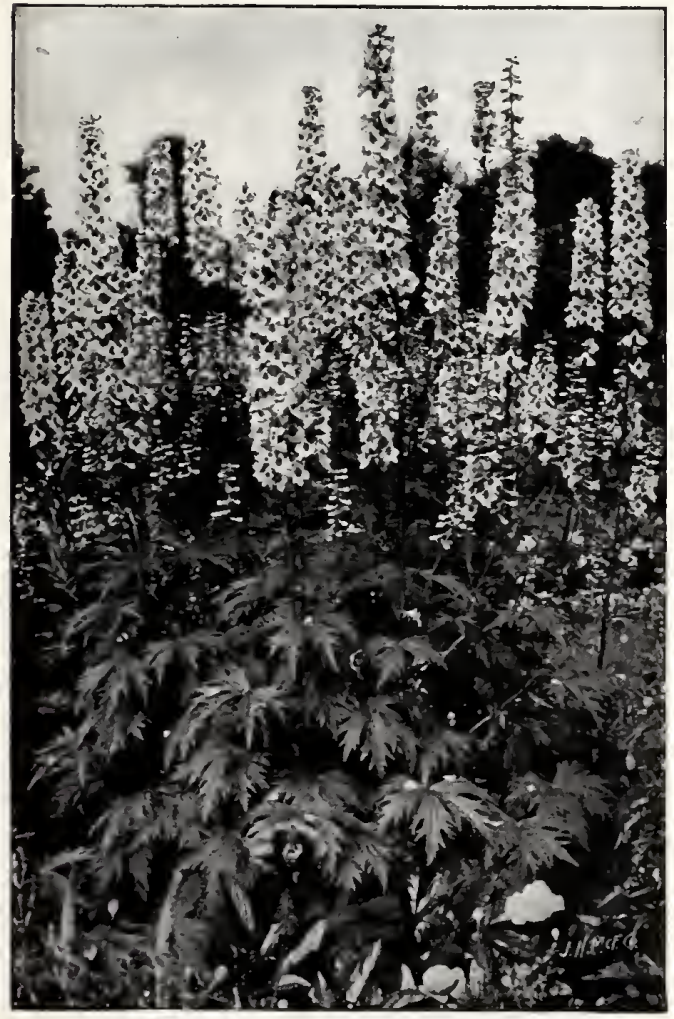

Delphiniums, Large-flowering Hybrids

\section{DOUIBLE DAISY (Bellis perennis)}

One of the prettiest spring flowers so largely used for bedding with pansies. They do not exeed 6 inches in height, and like the pansy, bloom continuously until hot weather. Seed may be sown in spring, but July and August are preferred. Proteet with leaves, or better still, winter over in eoldframes. H. H. P. Pkt.

Snowball. Beautiful double pure white....... 10 Double Mixed

$\frac{1}{4} \mathrm{Oz} .75 \mathrm{e}$ 10

\section{MONSTROSA, OR GIAN'T DOUBLE DAISIES}

This new strain of the well-known double Daisy is far superior to the older varieties. The flowers, while not produced quite so abundantly, are very much larger, extra-double and resemble small asters.

MONSTROSA alba. Flowers of the purest white

Pkt.

Rosea. Deep rose-pink

Mixed. White and pink.

DAISY, Shasta. See Chrysanthemum.

DATURA (Trumpet Flower). Plants 2 to 3 feet high, of strong, branching growth, with large, sweet-seented, trumpet-shaped flowers. H. H. A. . .

Cornucopia (Horn of Plenty). Fragrant, single white and purple flowers; exeellent variety

Golden Queen. Rich double golden yeliow

Double Mixed. Various eolors

\section{DELPIINIUM (Hardy Larkspur)}

A bed or border of Delphinium is very impressing. The plants are strong, and stately, with long spikes, carried well above the rieh, green foliage, each thiekly studded with brilliant flowers of every shade from the lightest blue to the deepest purple. Seed may be sown early, thereby seeuring flowering plants the first season. H. P.

Large-flowering Hybrids. A very fine, large-flowered,

2 to 3 feet in length and ranging in eolor from sky-blue to the deepest Pkt.

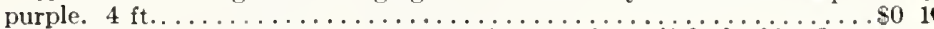
Double-flowering Hybrids. Immense spikes of beautiful double flowers,

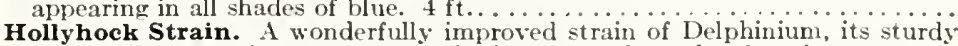
growth and general appearance reminding one of that other favorite perennial, the hollyhock. The ehief eharaeteristic of this variety is the enormous eentral spike which is eompletely covered with flowers appearing in all the various shades of blue. No hardy border is eomplete without a liberal planting of this popular perennial.

Zalil (Hardy Yellow Larkspur). Quite distinet fron all other hardy Larkspurs;

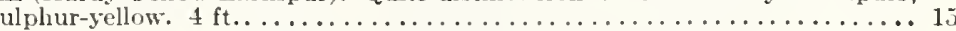

\section{DIGITALIS (Foxglove)}

The Foxglove is perfectly hardy and from June until August the tall spikes of gloxinia-like flowers are the admiration of all. They are fine when used as a background for dwarf plants or seattered among shrubbery, sueeeeding best in partially shaded positions. Sow the seed from May until August. 2 to 4 feet.

Gloxiniæflora. Handsome spotted flowers compaetly formed on spikes 2 feet Pkt. in length. Splendid for herbaceous borders and a general favorite for the old-fashioned garden. All eolors ........................................ Purpurea. The common varjety so often seen in the hardy border, and while Finest mixed

Maculata superba. Admired for its beautiful spotter flowers.

Monstrosa. Flowers large and attraetive, bell-shaped, and of exquisite ordinary size and unlike the preceding varieties, each spike terminates in one enormous saucer-like blossom. Finest mixed.

DIMORPHOTHECA aurantiaca (Afriean Golden Daisy). This showy, freeblooming annual, recently introdueed, will, before long, be one of our garden favorites. The plants, of dwarf, branehing growth, are covered with Daisylike flowers, of a rich orange eolor with blaek zone, whieh on sunny days glitters like gold.

DoLICHOS Lablab (Hyaeinth Bean). A splendid elimber with dense foliage for training over trellises, ete. The purple and white pea-shaped flowers are produeed in elusters and appear throughout the summer. $10 \mathrm{ft}$. T. A. Purple and White, Mixed .oz. $15 \mathrm{e} . . .05$

DRACAENA indivisa. An ornamental plant with long, narrow, green leaves, growing $2 \frac{1}{2}$ feet high. Used for eenterpieces in vases or flower-beds. G. P... 10 


\section{Dianthus, or Pinks}

A most satisfactory class of plants widely cultivated for their brilliantly colored flowers. The bushes are of compact growth, 12 to 18 inches in height, most easily grown and in continuous bloom until frost. The double Pinks are very pretty, quite similar to carnations and measure $1 \frac{1}{2}$ inches across. Seed should be started indoors as early as possible, preferably in March or April, while outdoor sowings should be made about May. Suitable for planting either in beds or borders.

\section{DOUBLE ANNUAL PINKS}

Chinensis, Double Mixed (China Pink). The favorite garden pink; flowers of me- Pkt. dium size, very double and fine for bouquets.

Mourning Cloak (White Frill). Rich, velvety crimson, edged white $\ldots \ldots \ldots \ldots \ldots$

Diadematus fl.-pl. (Diadem Pink). A very fine strain of this popular annual producing large, extremely double, fringed flowers in a grand assortment of colors.

Fireball. Very effective; brilliant dark scarlet. Splendid for cutting.

Heddewigii fl.-pl. (Double Japan Pink). A superior mixture, including Pkt.

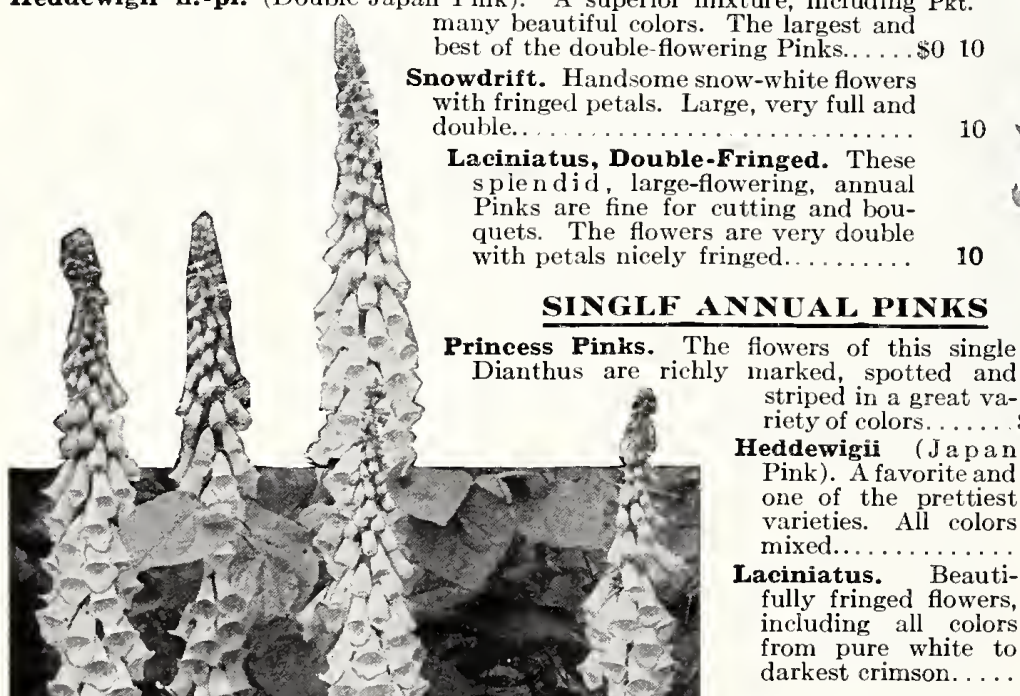

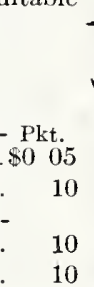

best of the double-flowering Pinks......

nowdrift. Handsome snow-white flower aciniatus, Double-Fringed. These splendid, large-flowering, annual quets. The flowers are very double with petals nicely fringed.
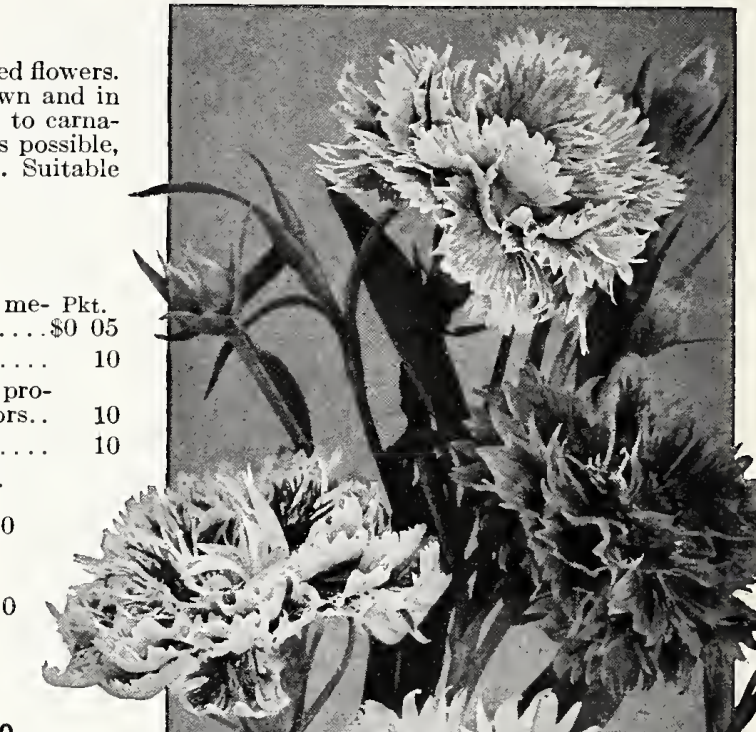
ECHINOCYSTIS lobata (Wild Cueumber Vine). Of rapid growth, attaining a height of Pkt. 20 feet or more in one season, and affording a most desirable covering where slade is desired. Small, white, fragrant flowers followed by ornamental scedpods. H.A. oz. 30e. $\$ \$ 0$ os

EUPHORBIA variegata (Snow-on-the-1Iountain). Readily grown in any garden. They grow 2 to 3 feet high, are very ormamental and from early summer until frost the green and white margined leaves attract unusual attention. Sow seed early and later set plants 1 foot apart. H.A...

FORGET-ME-NOT. See Myosotis.

FOUR O'CloCK. See Marvel of Peru.

FOXGLOVE. See Digitalis.

\section{GAILLARIIA}

Bright, showy annuals, blooming freely and continuously through the summer. The flower: varying from 2 to 3 inches in diameter, are borne on long, slender stems, and while red and yellow are the prevailing colors, pink, white and salmon are also ineluded.

Picta, Single Mixed. Very fine.

Picta Lorenziana, Double Mixed

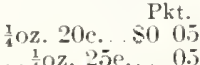

\section{PERTNNIAIA GAILIAA RIA}

A well-reeommended perennial for the hardy border which, if left undisturbed for several years forms large elumps 2 feet across. Flowers are similar to but larger than the annual varieties and equally good for cutting.

Grandiflora, Mixed. Fine, large-flowered sort Plit.

Grandiflora eompacta. Handsome, dwarf-growing variety with brilliantly eolored flowers, 3 inches or more in diameter.

GERANIUM zonale. The plants will produce flowers the first year if the seed is sown early. Fine for pots. Mixed

GLOBE AMARANTH (Gomphrena). This pretty annual everlasting, known also as Straw Flower and Bachelor's Button, makes a splendid border or bedding plant, and its elover-like flowers when dried are prized for bouquets. $2 \mathrm{ft}$. Finest Mixed.

GODETIA. Splendid for massing. The large, satiny flowers are produeed so profusely that

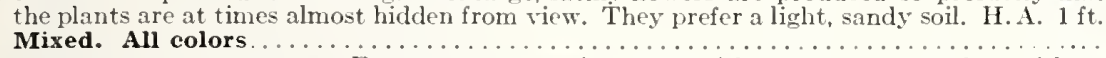

Ornamental Grasses. Form very attractive beds, either alone or together with other is both odd and beautiful.

pkt. 05

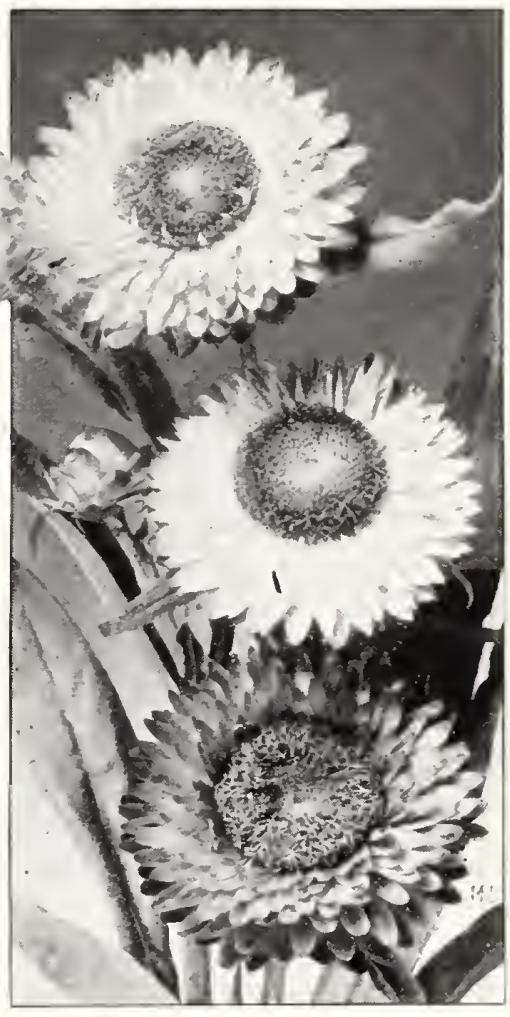

Helichrysum (Straw Flower)

\section{GOURDS Ornamental H.H.A.}

Affords a good eovering for fenees. The fruit of many shapes, sizes and colors, is both interesting and ornamental.

Chinese Luffa (Sponge, or Dishrag) Mock Orange

Mixed, Many kinds

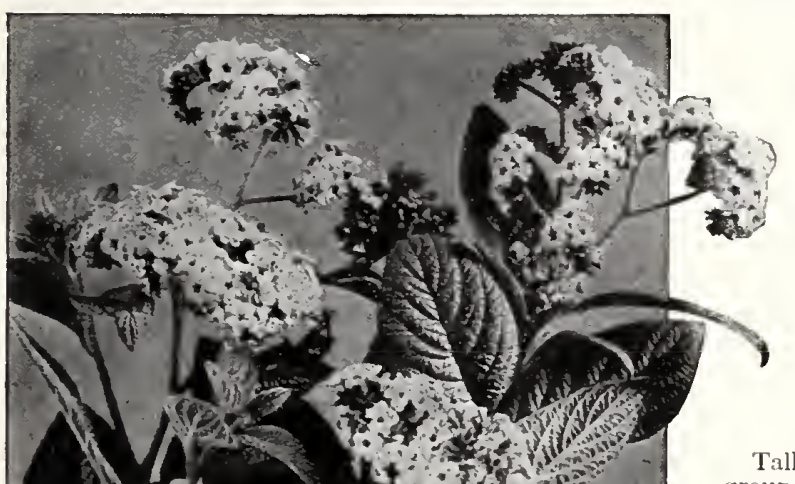

\section{GYPSOPHILA (Baby's Breath)}

The pretty white, star-shaped blossoms, formed in sprays, are very showy when used in bouquets with other flowers.

Elegans alba grandiflora. Those desiring bouquet flowers should not fail Plt. to try this variety. The small white flowers are produced in the greatest pro-

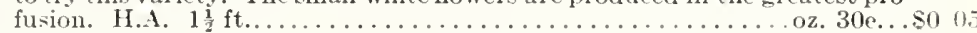
Muralis. A eharming little plant for edging; flowers bright rosy pink. Annual. Paniculata. A hardy perennial, but will bloom the first year if the seed is sown early. The sprays of white blossoms are exeellent for

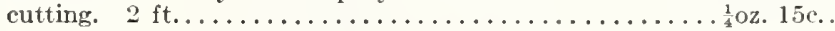

05

\section{HELICHRYSUM (Straw Flower)}

One of the favorite Everkastings. They are so easily grown, bloom so freely and continuously, that a bed or border of these pretty double annuals will afford eut-flowers all summer. Very useful for dry bouquets in winter. For early flowers sow seed indoors during March and when weather is warm in spring transplant to the garden, setting plants one foot apart. Sow outdoors in May. H.A. 1 to $2 \mathrm{ft}$.

Dwarf Double Mixed

Tall Double Mixed

$\frac{1}{4} \mathrm{Oz} \cdot 25 \mathrm{c} . \mathrm{skt}$. 10

\section{HELIANTHUS (Sunflower)}

Tall stately plants growing from 3 to 5 feet hich and used mostly for backgrounds and sereens. The seed should be sown outdoors in May where the plants are to remain.

New Red. A row or background of these new annual Red Sunflowers makes Pkt. a wonderfully brilliant display and from midsummer until fall they are a
blaze of large, single, red and gold flowers which vary from 4 to 7 inches in diameter

Stella. Finest for eutting; large, single, golden yellow flowers with black

Double Chrysanthemum-flowered. The finest of all double sunflowers.

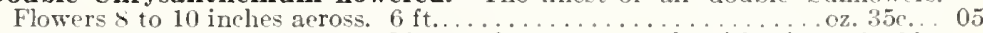

\begin{tabular}{c} 
Annuus globosus fistulosus. Plants of strong growth with giant, double, \\
golden yel low flowers. $5 \mathrm{ft} . \ldots \ldots \ldots \ldots \ldots \ldots \ldots \ldots \ldots \ldots \ldots \ldots \ldots$ \\
\hline
\end{tabular}

HELIOTROPE. Of all the fragrant flowers, Heliotrope is as sweet as any. It

is a splendid garden or house plant, growing from 12 to 15 inches high,

with large flower-heads and rich green foliage. Sow seed early in March to obtain flowers the first year. H. H. P. Giant Mixed. 


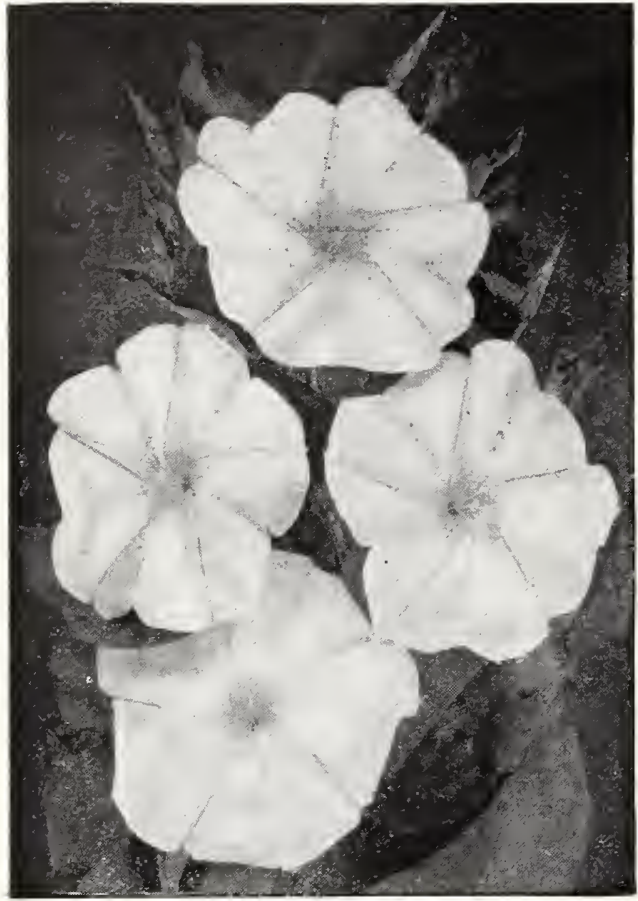

Ipomœa, Moonflower

\section{HOLLYHOCK}

Hollyhocks are the pride of the country gardens. Their stately growth, large, double flowers, many beautifully fringed and ranging in an endless variety of colors, all help to make this one of the finest perennials. Sow seed from May to July and if possible protect plants the first year. We offer a superb strain of Chater's Double Holly* hocks. $6 \mathrm{ft}$.

\section{CHATER'S SUPERB VARIETIES}

Double Crimson

Double Pink.

Double Purple-violet.

Double Salmon-rose. .

Collection, one pkt. each of above 7 separate colors, $50 \mathrm{cts}$.

Mammoth Allegheny. Handsome

fringed flowers, averaging 4 to 5 Pkt.

inches across. Mixed colors......\$0 10

Double German. A fine strain. All

colors, mixed..........oz. \$1.... 05

\section{EVERBLOOMING ANNUAL HOLLYHOCKS}

The chief characteristic of this variety is that they bloom the first year, providing the seed is sown early in March. They are equally as hardy as the perennial varieties.

Double Annual Mixed. The majority are double and semi-double, but single specimens also appear. Pkt.

Single Annual Mixed............ 05 HUMULUS Japonicus (Japanese Hop). Grows from 10 to 15 feet high, and its dense green foliage retains its rich color

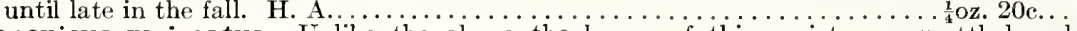
Japonicus variegatus. Unlike the above, the leaves of this variety are mottled and streaked silvery white; pretty and ornamental . HUNNEMANNIA fumariæfolia (Bush Eschscholtzia) Bushy plants, $\ldots$ feet high with fern-like foliage and large, bright yellow, tulip-shaped flowers. H. A....... $\frac{1}{4}$ oz. $25 \mathrm{c} \ldots 05$ HYACINTH BEAN. See Dolichos.

ICE PLANT (Mesembryanthemum crystallinum), A dwarf, trailing annual, useful for vases and rock work. Thick ice-like foliage

IMPATIENS. As pot plants for the house or for bedding in partly shaded places, the Impatiens are well recommended. They bloom freely, and their brilliant, colored flowers form a pretty contrast with the glossy green leaves.

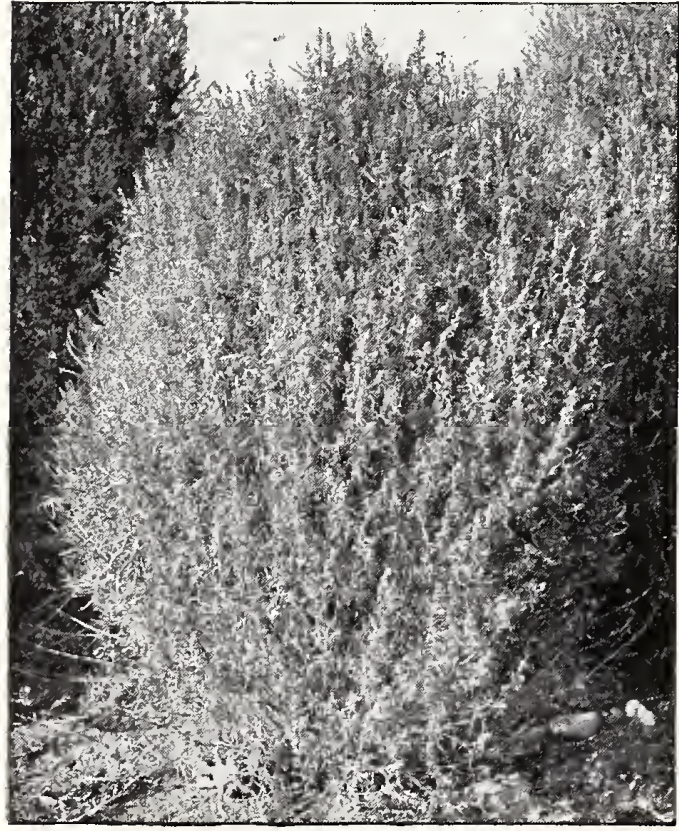

Kochia, Summer Cypress
Sultani. Splendid variety; bright rosy scarlet. $1 \mathrm{ft}$.....

Holstii. Large vermilion-scarlet flowers.

Holstii Hybrids. Many beautiful colors. Splendid for summer or winter blooming... 15

\section{IPOMOEA}

As a covering for walls, porches, etc., these free-blooming, quick-growing annual climbers are unsurpassed.

Bona Nox (Evening-Glory).

Large, handsome violet-blue Pkt.

flowers...........oz.25c...\$0 05

Coccinea. Pretty scarlet, star-

shaped blossoms; dense foliage.. 05 Grandiflora alba (Moonflower).

05

One of the finest and quickest growing climbers. It has beautiful heart-

shaped leaves and hundreds of immense pure white, fragrant flowers, Pkt. which open in the evening and on cloudy days. 15 to $20 \mathrm{ft} . \ldots \frac{1}{4} \mathrm{oz} .25 \mathrm{c} . . \$ 010$ Rubro corulea (Heavenly Blue). The flowers are borne in clusters and of

a lovely sky-blue color

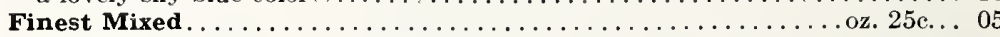

JACOBAEA elegans fl. pl. Very pretty annual, about $1 \frac{1}{2}$ feet high, continuing

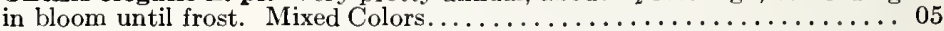

KOCHIA tricophylla (Summer Cypress). An ornamental annual with cypress-like foliage. During the summer the plants are light green, but turn to a rich carmine in fall, at which time they are also covered with small, bright scarlet flowers, giving the plants an appearance similar to a

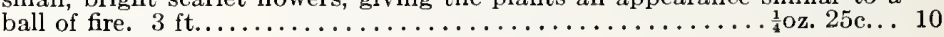

LANTANA hybrida nana compacta. Shrubby plants with beautiful heads of verbena-like flowers, valuable alike for the garden or house. H. H. A. 05 


\section{H. BRUNJES \& SONS 留 BROOKLYN, N. Y. V RELIABLE SEEDS}

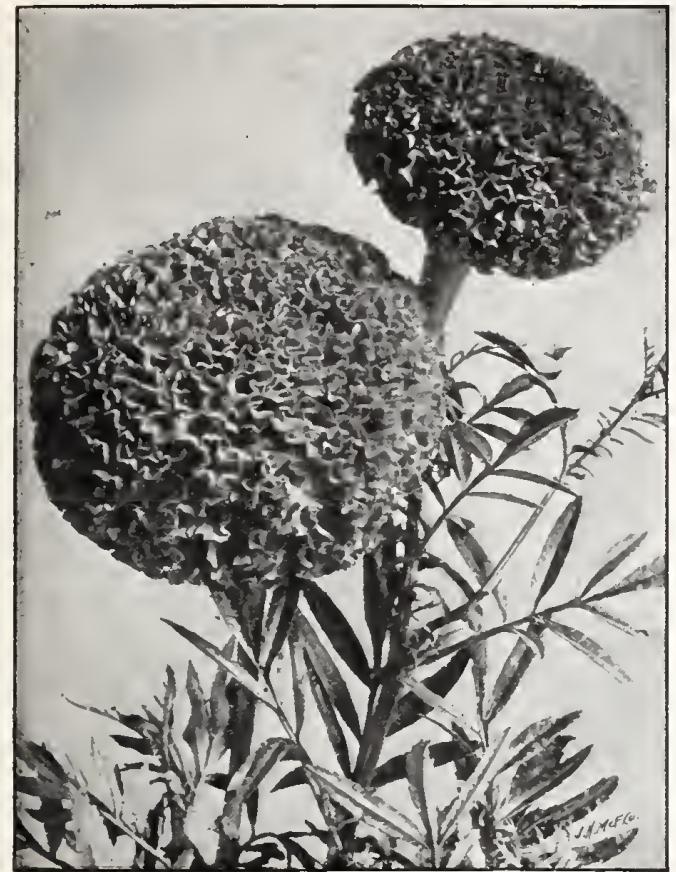

Marigold, African, Orange Prince (see page 14)

\section{LARISPUR}

A favorite German flower appearing in many colors, as white, pink, rose and all shades of blue. Very effective when grown in elumps, and the taller sorts are fine for cutting. Sow outdoors early in spring.

\section{DOUHLE STOCK- FIOW IERED}

Supcrb for cutting. 2 to 3 feet.

Pure White Pkt.

Bright Rose

so $10 \mid$ Violet

10 Finest Mixed

Double Dwarf Rocket. $1 \mathrm{ft}$. Finest Mixed

Tall Rocket. Splendid variety; long spikes of double flowers, $2 \mathrm{ft} \ldots \ldots .10$

Emperor. A large-flowered, free-blooming Larkspur. Mixed Colors.

LINARIA Cymbalaria (Kenilworth Ivy). Dwarf trailing plant for hanging baskets, rockwork, etc. Lavender and purple flowers............... 10

LINUM grandiflorum rubrum (Scarlet Flax). Effective, free-flowering

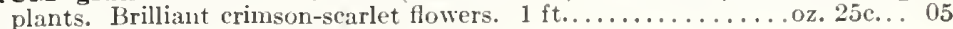

Flavum. Beautiful golden yellow perennial................... 10

Perenne (Blue Flax). Bright blue. H. P. $1 \frac{1}{2} \mathrm{ft} \ldots \ldots \ldots \ldots \ldots \ldots \ldots$

\section{TRAILING VARIETIES}

Gracilis. Light blue. Pretty for vases and hanging baskets; trailing

\section{LOBELIA}

Neat little plants so much admired when used for edging, bedding or rockwork. Though but 6 inches high, they are in constant bloom all summer and in a slightly shaded position remain so until fall. II. H. A.

Speciosa. Best dark blue trailing Lobelia

\section{Pkt.}

\section{COMPACT IBEDING VARIETIES}

Emperor William. Sky-blue flowers; compact plant, splendid for edging Crystal Palace compacta. Strikingly beautiful: superior dark blue bedding Lohelia...................................... 1/80z. 50e. Pumila splendens (Bedding Qucen). Dwarf and compact: flowers rich purplebluc, with clear white eye.

White Gem. Finest pure white for bedding.

Finest Mixed. Only the dwarf, compact varieties.

Cardinalis. Hardy perennial, with long spikes of dazzling scarlet flowers. $3 \mathrm{ft}$

LOPHOSPERMUM scandens. A tender annual climber, having dark rosecolored, trumpet-shaped flowers. $10 \mathrm{ft}$.

\section{LUPINUS}

The annual Lupines form nice plants for bedding, while the tall-growing perennial sorts are very attractive when used as a baekground or border. All are showy, freeflowering and have long spikes of pea-shaped flowers.

Annual Mixed, All Colors. $2 \mathrm{ft}$.

Pkt.

Polyphyllus roseus. Invaluable for rutting. Handsome spikes of rosereolored

flowers. Blooms in May and June. H. P.

Polyphyllus, Mixed. Perennial varieties. $4 \mathrm{ft}$.

L YCHNIS chalcedonica. Hardy perennial of striking appearance, with brilliant scarlet flowers. $2 \mathrm{ft}$...

Chalcedonica, Mixed. Scarlet and white

Haageana. A desirable plant for the hardy border. Single flowers of deepest searlet. $1 \mathrm{ft}$. . .

MALOPE grandiflora purpurea. Hardy annual, bearing mallow-like flowers of a deep red color from July until frost. $2 \mathrm{ft}$.

MATRICARIA (Feverfew). A half-hardy percnnial which blooms the first year from sced. The small, very double white and yellow flowers are produeed in the greatest profusion all summer. Seed may be sown in $\mathrm{May}$, but letter still, during March indoors.

Capensis fl. pl. The finest white variety for cutting. $1 \frac{1}{2} \mathrm{ft}$..

Tom Thumb, Double White. This dwarf-growing Feverfew is splendid for bedding, edging or pot culture, $1 \mathrm{ft}$.

Golden Ball. A bed or border of this charming variety with its countless numbers of small, double, golden ycllow flowers makes one of the most beautiful sights all summer. $1 \mathrm{ft}$. .

MATTHIOLA bicornis (Evening-scented Stock). A small-flowered pink-lilac annuai, admired for its sweet fragranee..........................

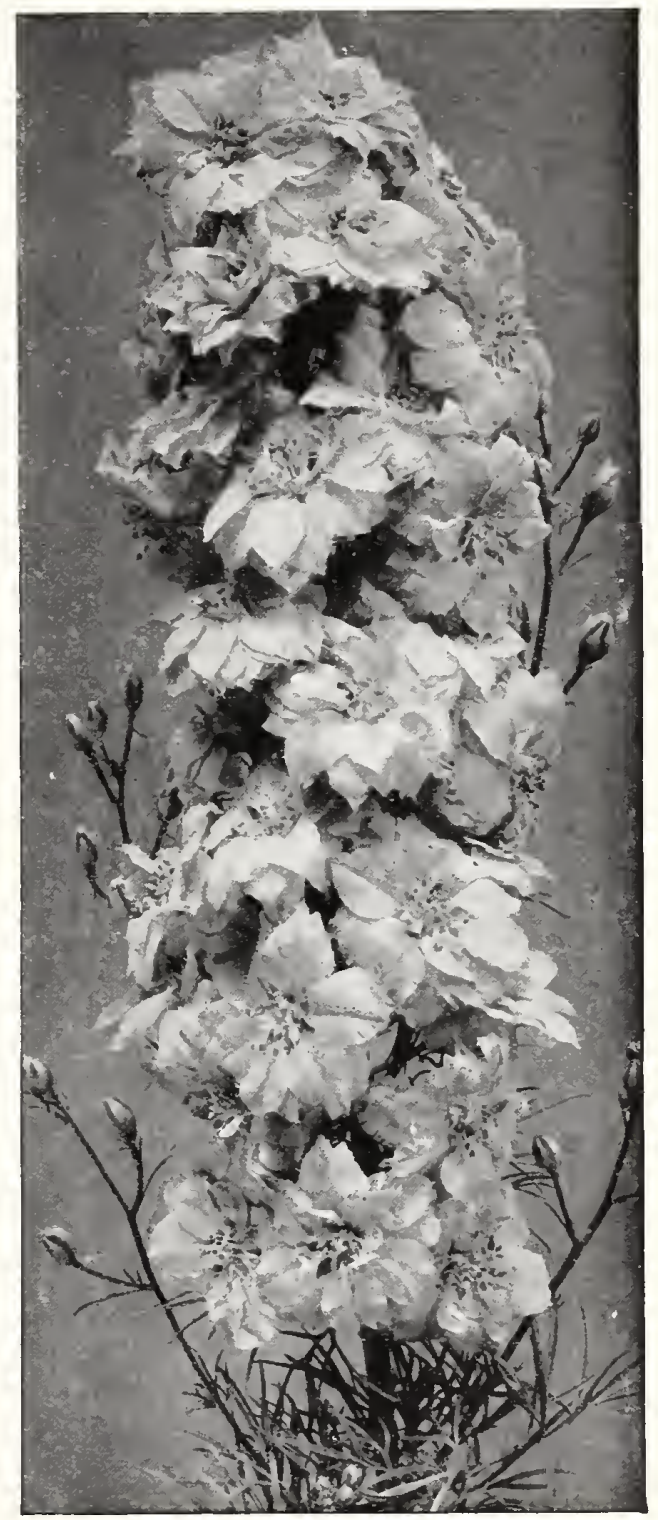

Larkspur, Double Stock-Flowered 


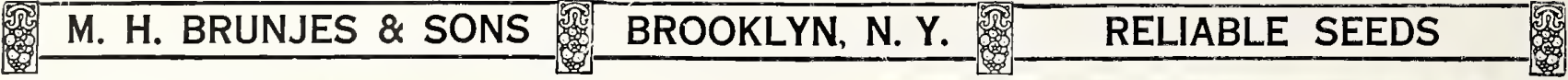

\section{MARIGOLD}

The Marigold shows its full value toward fall, when most bedding plants are usually past their best. Many prefer the African varieties, with their cxtra-large, double yellow and orange flowers, but the dwarf, smaller-flowered French sorts, with their handsome spotted and striped flowers, are justly popular and equally beautiful. H.H.A.

\section{DOUBLE AFRIGAN MARIGOLDS}

Lemon Queen. Of immense size, densely double and clear Pkt.

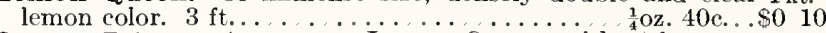
Orange Prince. A mate to Lemon Queen, with rich, orange-

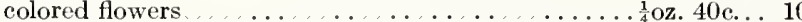

Eldorado. Handsome, quilled flowers 3 inches or more in diamcter, and ranging in various tints of yellow and orange. One of the finest: extremely double. $3 \mathrm{ft} . . \ldots \ldots \ldots \ldots, \frac{1}{4} \mathrm{oz} .40 \mathrm{c} .$.

Tall Double Mixed ................. . $1 / 4 \mathrm{oz} .30 \mathrm{c}$.

Dwarf Double Mixed. 18 inches..............

\section{DWARF FRENGH MARIGOLDS}

Dwarf Dark Brown. One of the finest for bedding, rich velvety color

Dwarf Orange. Splendid for borders.

Dwarf Gold-Striped. A favorite and very effective varjety; fine for pots. $1 \mathrm{ft}$

Legion of Honor ("Little Brownie"). This charming singleflowered Marigold is a mass of flowers all summer. Yellow with reddish brown spot.

Dwarf Double Mixed

10z. $30 \mathrm{c} . .10$

MARVEL OF PERU (Four-o'Clock). Well-known hardy annuals. The bushes grow 2 to 3 feet high and produce often 100 or more flowers on a single plant.

Finest Mixed. All colors

oz. $20 \mathrm{c} . . .05$

\section{MIGNONETTE (Reseda)}

The Mignonette is universally admired for its delicate perfume and singularly pretty spikes of bloom. Liberal sowings from April to July will afford a continuous supply of this favorite flower, so

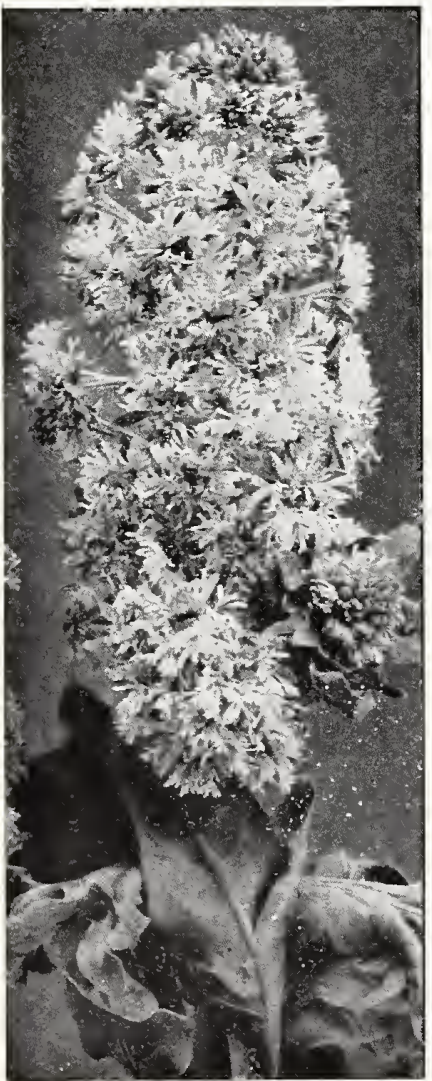

Mignonette Machet largely used and so much admired for bouquets. Mignonette succeeds best if sown where the plants are to bloom H.A. Pkt.

Goliath. An excellent popular annual with very large trusses of fire-red flowers; plants of strong and robust growth. Fine for forcing and garden culture...........\$0 15

Machet. One of the very ist or private gardens. Dwarf, compact plants and large, thick spikes of deliciously fragrant flowers. Our strain is fine. $\frac{1}{4}$ Oz. $25 \mathrm{c}, 1$

Allen's Defiance. Splendi for cutting The long spikes are thickly studded with sweet-scented flowers ..... $\frac{1}{4} \mathrm{oz} .25 \mathrm{c} \ldots 10$

Ruby. A large-flowering Machet Mignonctte with coppery scarlet flowers. . 10

Golden Queen. A dístinct variety; golden yellow. Large-flowering ${ }^{\text {oz. } 40 \mathrm{c} \text {. }}$. scented.... oz. 20c.. 05

MUMULUS tigrinus (Monkey Flower). Dwarfgrowing plants, with very showy, spotted. and tigered flowers.

Moschatus(Musk Plant). A frec-blooming, small, ycllow-flowered variety suitable for hangingpots and vases. Blooms the first ycar from seed sown in March. $1 / 2 \mathrm{ft}$.. 10 10
10 10 . .

\author{
.
}



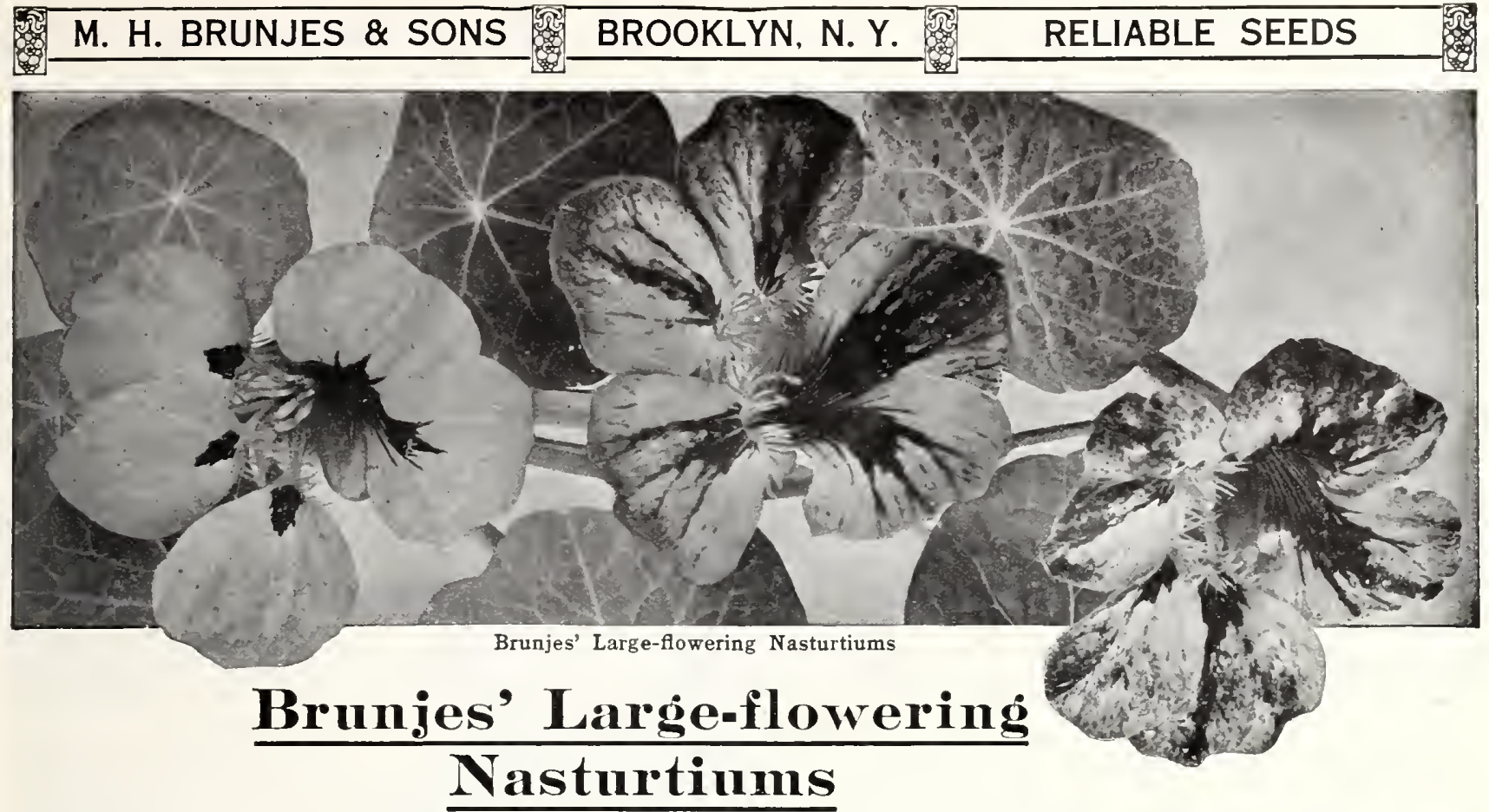

There are few flowers so easily grown as Nasturtiuns, and, unlike most flowers, they grow and bloom best on ponr sandy soil. The dwarf or Tom Thumb varieties yrow about 1 foot hish and are very desirable for bedding, bordering, or window-boxes. The tall Nasturtium is a favorite clinber for covering fences, rockeries, etc., while both are good for cutting and vase decoration. Our strains of both tall and dwarf Nasturtiums are notea for their large and beautiful flowers and great diversity of rieh and brilliant colors. H.A.

\section{Dwari, or Tom Thumb Nasturtiums}

Aurora. Yellow, veined carmine.

Chameleon. Several colors on one plant

Empress of India. Deep erimson; dark-leaved.

Golden King. Large golden yellow flowers.

King of Tom Thumbs. Intense searlet; dark-leaved.

Pearl. Crcamy white...

Rose. Blush-rose

Yellow. Pure vellow.

Dwarf Large-flowering Mixed

$$
2 \text { ozs. } 25 \text { cts., } \frac{1}{4} \text { lb. } 50 \text { cts., ib. } 31.50 \% 05
$$

Collection, cne pkt. each of the above 8 varieties, 30 cts.

\section{Tall, or Climbing Nasturtiums}

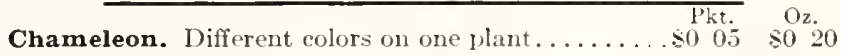
Dark Crimson

Orange. Large flowers.................... $05 \quad 20$

Pearl. Creany white..................... $05 \quad 20$

Yellow Spotted Scarlet................. $05 \quad 20$

Scarlet. Very bright; green-leaved............ $05 \quad 20$

Yellow. Pure yellow...................... $05 \quad 20$

Tall Finest Mixed . 2 ozs. 25 ets., ${ }_{4}^{1}$ lb. 50 ets., lb. $\$ 1.50,05 \quad 05$

Collection, one pkt. each of the above 7 varieties, 25 cents

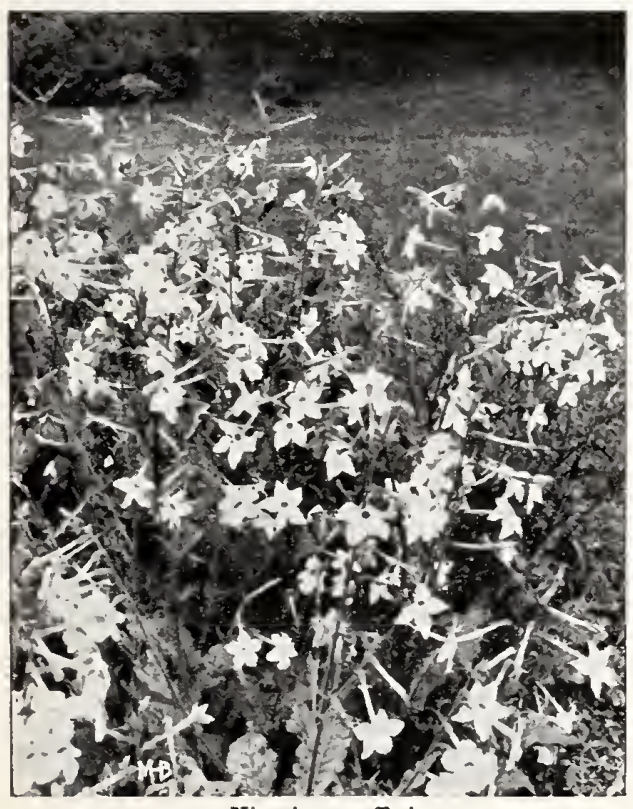

Nicotiana affinis

LOBB'S CLIMBING NASTURTIUM (Tropaolum Lobbianum). The Pkt. Oz.

flowers are smaller but somewhat brighter than the ordinary tall Nasturtium. $6 \mathrm{ft}$.

Mixed. All colors.

$\frac{1}{4} 1 \mathrm{~b}, 50 \mathrm{c} \ldots 8005$

MADAME GUNTHER'S HYBRIDS. A particularly fine strain of this

well-known climber embracing a large variety of the nost beautiful colors:

dark foliage..................................... 05

\section{NICOTIANA}

Long- and free-blooming annuals of the tohace family with tubular-shaped, fragrant flowers. The plants are of rapid growth and present a glorious effect in the garden, especially if planted in groups, blooning continuously until autunn.

Affinis. Grows 2 to 3 feet high, and has pure white, fragrant flowers which open Pkt.

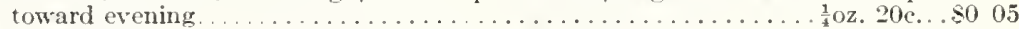

Affinis Hybrids. Large-fowering hybrids appearing in purple, dark red, lilac,

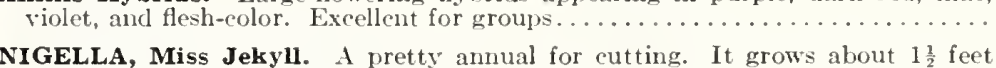
high, has fine, fern-like foliage and large, double, cornflower-blue flowers. Sow seed in the open ground early in spring. ................

Damascena (Devil-in-a-Bush). Mixed, double

Hispanica. (Love-in-a-Mist.) Mixed, single...

CENOTHERA (Evening Primrose). A hardy annual of easy culture, bearing large, showy flowers which do not fully open until evening. $1 \frac{1}{2} \mathrm{ft}$.

Mixed Colors

OXALIS. Dwarf plants of trailing habit, suitable for borders but especially recommended for hanging-baskets. Blooms first year. H. H. P.

Rosea. Pretty for baskets; rose-colored flowers.

Tropæoloides. Fine for borders. Deep yellow flowers; brown foliage. $\frac{1}{2} \mathrm{ft} \ldots \ldots$ 
M. H. BRUNJES \& SONS B BROOKLYN, N. Y.

RELIABLE SEEDS

\section{H. BRUNJES \& SONS' \\ Gian't Spencer Sweet Peas}

While Sweet Peas have always been very popular, it has been the introduction of the Spencer type that has caused them to be the most talked-about flower at the present time. The vines are of strong, vigorous growth, surpassing the standard sorts in this respect. The wonderfully large, fragrant flowers, measuring up to 2 inches aeross, are gracefully formed, on long stout stems, eaeh bearing three and often four blossoms. For eutting, vase deeoration, and exhibiting, the Sweet Pea stands supreme, and every garden, whether large or small, should contain some of the new Speneers this year.

Culture.-A decp, rieh, and rather moist soil is best adapted to growing Sweet Peas. A plaee at least 1 foot wide and not less than a foot doep should be thoroughly spaded, and a liberal amount of manure or bone meal added. Very early in spring, preferably in March or April, after digging a trench 5 to 6 inehes deep, sow the seed 1 inch deep and sow thinly. When 3 to 4 inehes high, thin out the plants to 8 inehes apart and gradually fill in the trench with soil. A trellis or brush should be provided for their support. Piek flowors frequently, otherwise the plants will soon stop flowering

\section{Mixtures of Sweet Peas}

Brunjes' Giant Spencer Mixed. A spaee in every be reserved for a liberal planting of this grand mixture. It is composed entirely of the Giant Speneers, the largest and most beautiful of all Sweet Peas, and we fcel eonfident that our eustomers will be more than pleased with the results obtained from this superb mixture. Pkt. 10 ets., oz. 20 ets., $1 / 4 \mathrm{lb} .60$ ets., lb. $\$ 2.25$.

Early-flowering Spencer Mixed. An $\begin{gathered}\text { An } \\ \text { of }\end{gathered}$ Speneer Peas highly recommended and largely used by florists. Their early flowering, being at least four to five weeks earlier than the late Speneers, makes them espeeially fine for the home garden. Our mixture eontains all the beautiful colors, including the newer in troduetions. Pkt. 10 ets., oz. 35 ets., $1 / 4$ lb. $\$ 1,1 \mathrm{lb} . \$ 3.50$.

\section{Perennial Peas (Lathyrus latifolius)}

A hardy elimber with large elusters of red, white, and pink blossoms. Fine for cutting. HP. $8 \mathrm{ft}$. Finest mixed, pkt. 10 ets., $1 / 4 \mathrm{oz} .25$ ets.

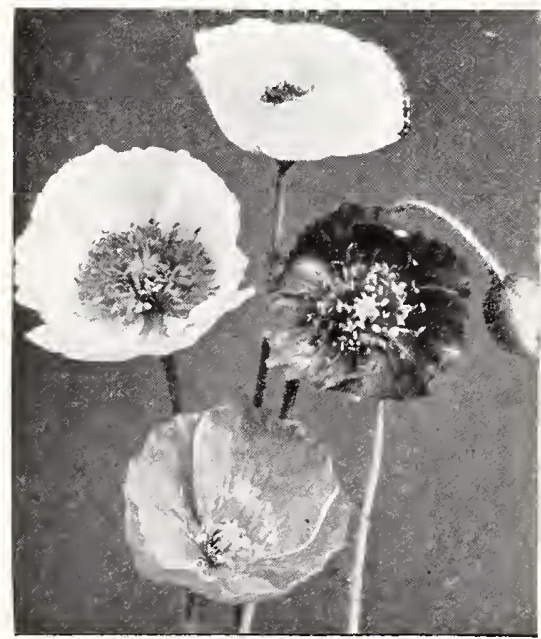

Oriental Poppies. See page 48

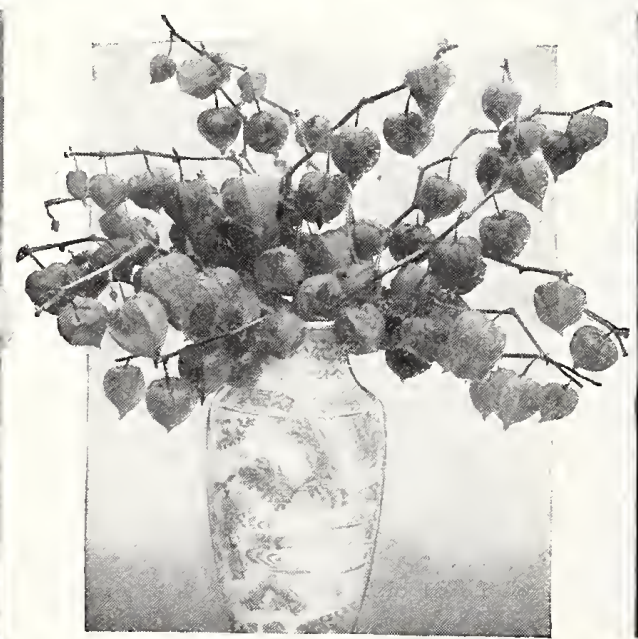

Physalis. See page 47

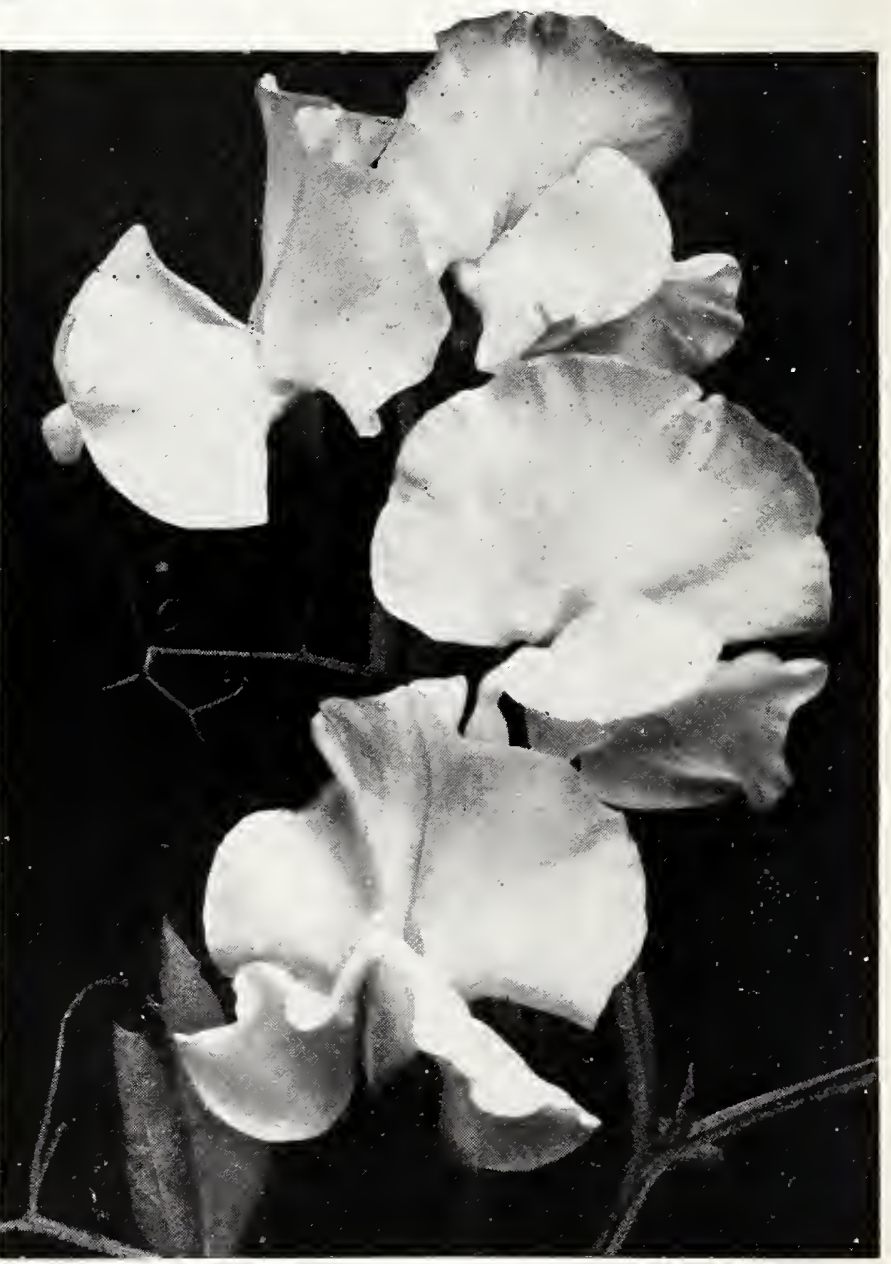

Brunjes' Giant Spencer Sweet Peas

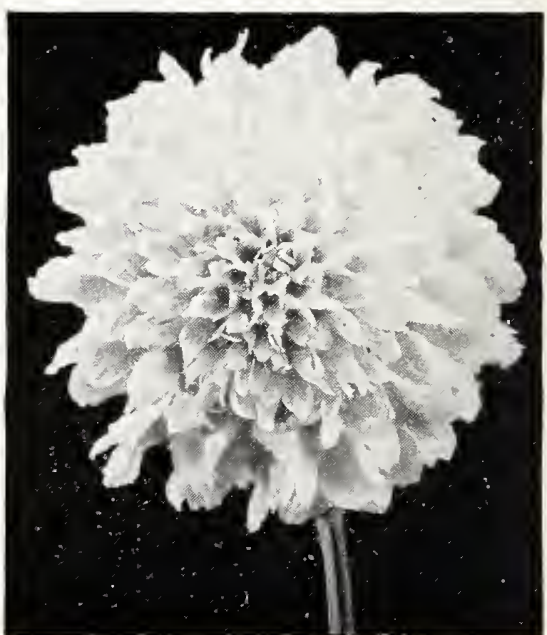

Double Scabiosa. See page 51 


\begin{tabular}{|c|}
\hline M. H. BRUNJES \& SONS \\
\hline
\end{tabular}

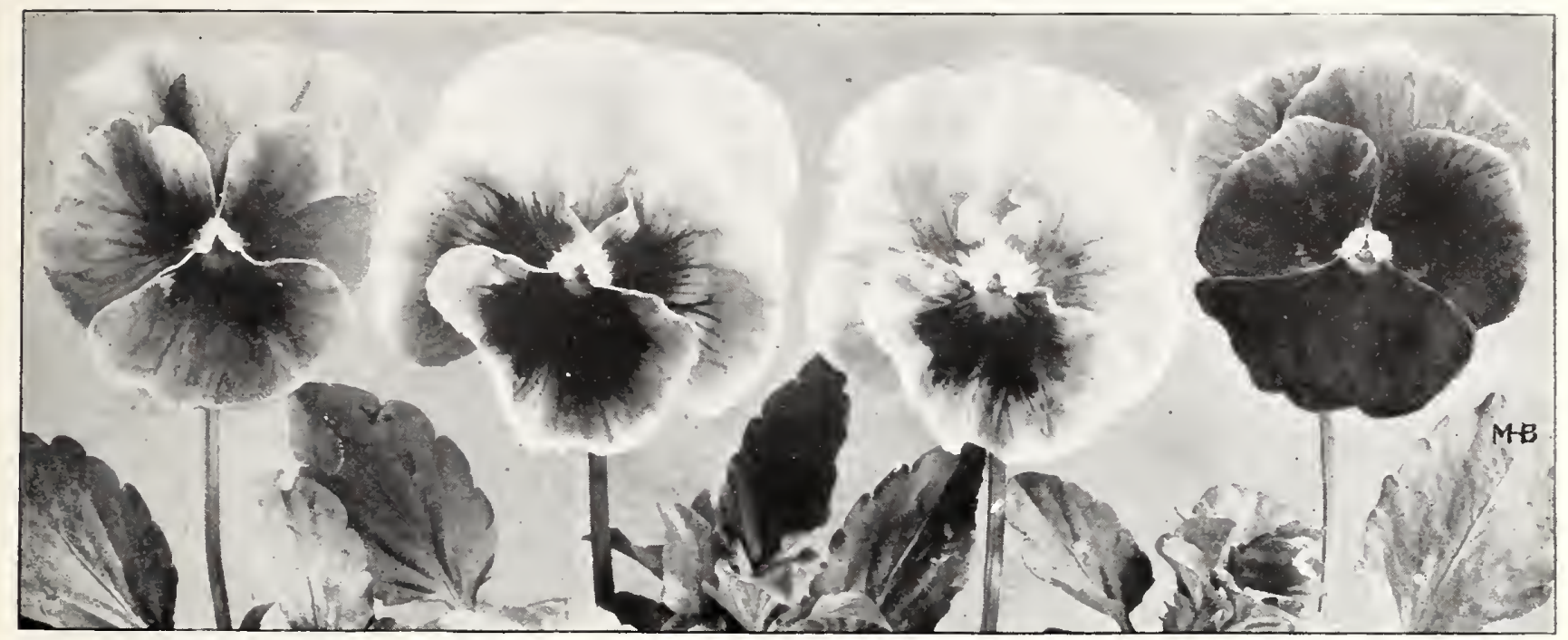

Brunjes' Giant Beauty Pansies

\section{PANSIES}

The Pansy has become one of our most popular plants for bedding and may be seen in bloom almost the year round, but it is during May they appear at their best. To have them bloom in May, the seed should be sown during July or August, so that it may develop into strong plants for remaining outdoors over winter, with a slight protection. For later flowers sow seed in early spring.

\section{GHOICE MIX'TURES OF PANSIES}

Brunjes' Giant Beauties. A superior mixture containing for their richness of color, perfect form, and immense-sized blooms. Especially recommended for either early spring or late summer sowing. Pkt. $25 \mathrm{cts}$, $\frac{1}{8} \mathrm{Oz}$. $\$ 1$.

MASTERPIECE. One of the larger-flowering Pansies; distinct from all others, in that the petals are beautifully frilled or ruffled, giving the flowers an unique, though very fascinating appearance. In color, they range chiefly through the clarker shades, Pkt. $20 \mathrm{cts}, \frac{1}{8} \mathrm{oz} .75 \mathrm{cts}$.

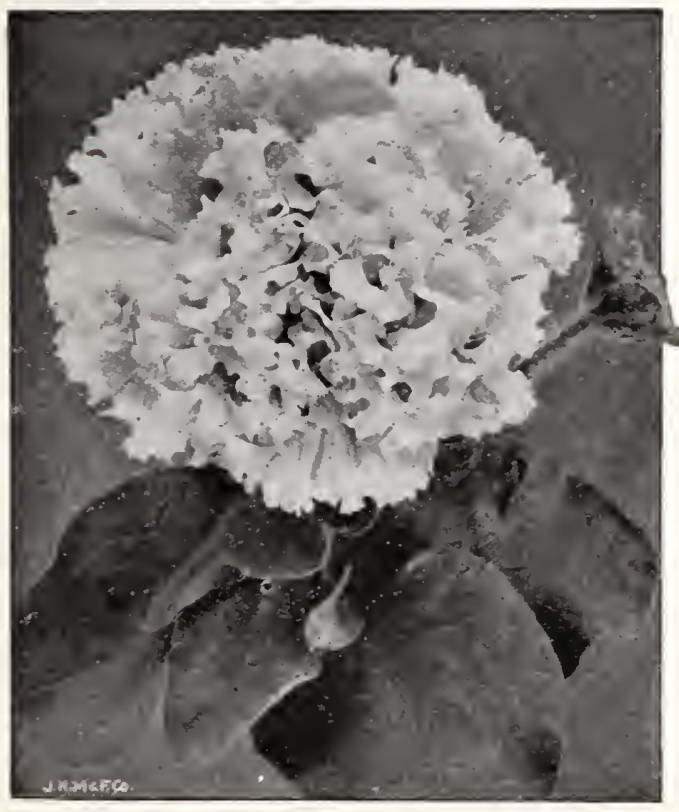

Petunia, Double Large-flowering Fringed

\section{GIANT SEPARATE GOLORS OF PANSIES} GIANT BLUE. Bright cornflower-blue, with dark eye........ $\frac{1}{4}$ oz. $\$ 1 \ldots \$ 010$ GIANT GOLDEN QUEEN. Pure yellow................... GIANT GOLDEN YELLOW. Center staincd with black; läge and very showy. 10 Giant Lord Beaconsfield. Rich, veivety purple-violet, the upper white. Very popular and unsurpassed for beding........... Giant Mercury. The flowers are of enormous size, well formed and of a

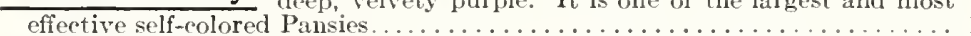
GIANT SNOWFLAKE. Especially fine for bedding; large, pure snow-white flowers
GIANT STRIPED. Of striking beauty. Howers well formed and striped with

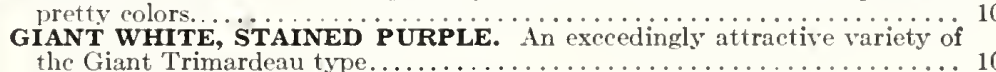

\section{TUFTED PANSIES (Viola cornuta)}

Although the flowers are somewhat smaller than the more popular Pansies, this class of Violas produces its blossoms in greater abundance and remains in bloom until early fall. From seed sown in April blooming plants may be had in June.

Choice Mixed. Many handsome colors. Pkt.

PENTSTEMON Hartwegii, Mixed. Very effective plants, growing 2 feet high, with long spikes of brilliant, richly colored flowers, minn beautifully
spotted. Seed sown early in March in the house will produce blooming PHYSALIS Franchetii (Chinese Lantern Plant). A hardy perennial, about 2 feet high, blooming the first year from seed and admircd for its brightcolored seed-pods, which are at first golden yellow but later change to orange-scarlet. The pods are quite similar in appearance to small lanterns.. 10 


M. H. BRUNJES \& SONS

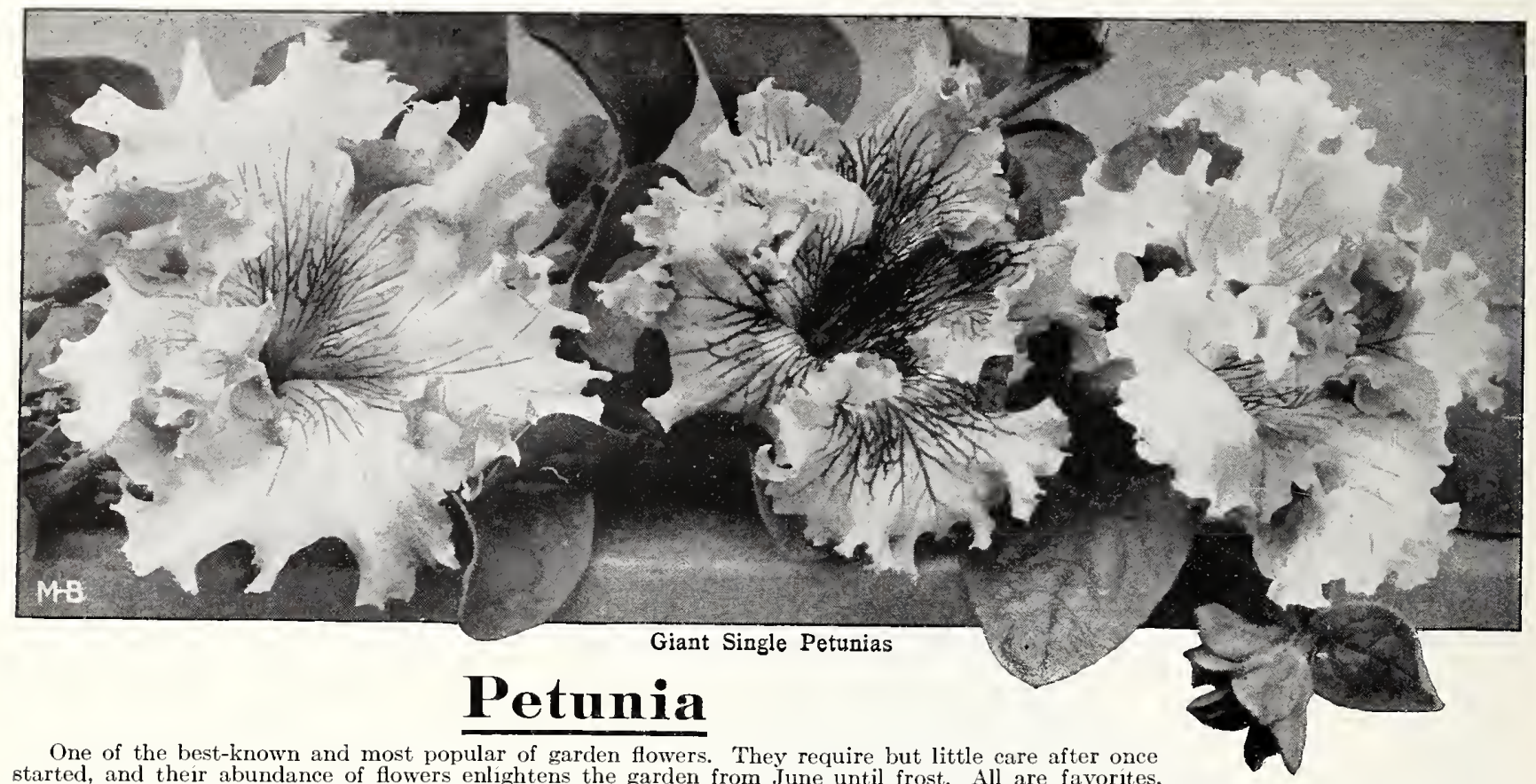
started, and their abundance of flowers enlightens the garden from June until frost. All are favorites, and whether for bedding, borders or massing, they have few superiors. The bedding varicties may be sown outdoors in Mav, but the large-flowering single and double Petunias should be sown in boxes in the house during March and April. H.H.A. $1 \frac{1}{2} \mathrm{ft}$.

\section{Single Large-flowering Petunias} Brunjes' Giant Prize Mixed. You cannothelp but ad- Pkt. Petunies, and this Prize strain is the mire our giant-flowering The flowers are of enormous size, often measuring 5 inches across, while the colors are most beautiful, some soft and delicate, others rich and gorgeous, and all an object of great beauty. One packet of seed will produce sufficient plants for a good-sized bed $\$ 025$

Giants of California. Splendid large-flowering strain, with handsome fringed and ruffled flowers. The colors range from the purest white to pink, carmine, crimson, and maroon; beautifully penciled, and veined at the throat...................

\section{Poppies}

One of the prettiest old-fashioned annuals with large double or single flowers of almost every color imaginable, blooming profusely during the summer months. A light, sandy soil is best suited for their culture. The seed germinates quickly and should be sown outdoors very early in spring, where the plants are to bloom. See that plants are thimned out to 8 inches apart.

Santa Rosa Shirley. A superior strain of the grand Shirley Poppy, which is Pkt. noted for its beautíful colors and extra-large flowers.

Admiral. A bed or border of this large, single-flowered variety is very striking Its flowers are of purest white with a broad band of brilliant scarlet at the top. 05 Tulip-Poppy (Glaucium). The brightest of all; dazzling scarlet tulip-like flowers. $1 \mathrm{ft} .10$ Single Finest Mixed. A bright, showy mixture $\quad . . . . . .0 .02 .25 \mathrm{c} . .05$

Double Carnation-flowered. The large, ball-shaped flowers are deeply cut and fringed, very double, and appear in many different colors, including both the solid and striped varieties. $2 \mathrm{ft}$. Finest Mixed .............. 35c... 05

Double Peony-flowered. One of the best double sorts, having immense, peonyshaped flowers, often measuring 4 to 5 in. across. 2 ft. Finest Mixed. . oz. 35c. .

\section{Iardy Perennial Poppies}

Every hardy border should have some of these stately perennial Poppies. They are perfectly hardy and after once planted will take care of themsclves, increasing in size and beauty year after year. Seed may be sown in the spring, and although the plants disappear during the hot summer months they reappear in the fall and should then be transplanted to permanent positions. Seed can also be sown in the early fall. Pkt. Bracteatum. Large, single, crimson-scarlet flowers. $3 \mathrm{ft}$.

Orientale. Affords a most effective display during June and July. Flowers measure 5 to 6 inches across; dark red with black spot on each petal. $3 \mathrm{ft}$. .

Orientale Hybrids. Exceedingly large, single flowers with various shades of rose, scarlet, lilac, and mauve, $3 \mathrm{ft}$

Nudicaule (Iceland Poppies). These dwarf Poppies, with their light green foliage and fragrant flowers, bloom the first year from seed. $1 \mathrm{ft}$. Single Mixed...... 10
Single Bedding Petunias Cherry-red flowers with white throat. . $\frac{1}{4} \mathrm{oz} .60 \mathrm{c} . . .10$

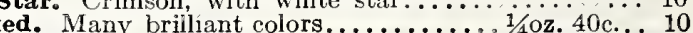

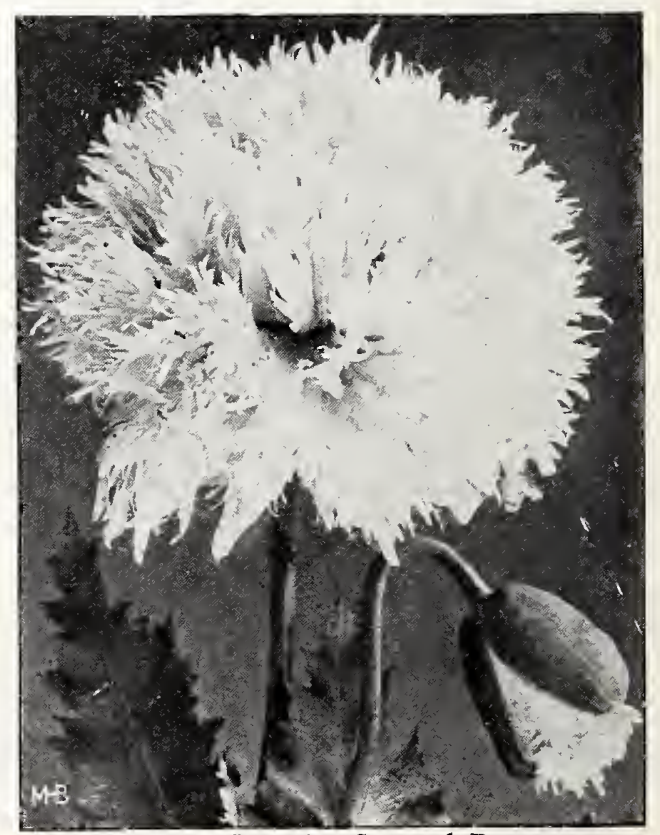

Double Carnation-flowered Poppy 
M. H. BRUNJES \& SONS

\section{Phlox Drummondi}

This hardy annual, with its bright showy flowers, can not be too highly recommended for bedding purposes or ribbon borders, as the plants remain in bloom until late in summer. The Grandiflora variety, if planted in rich soil, attains a height of 12 to 15 inches and affords splendid spikes of flowers for cutting.

\section{GRA NDIFLORA VARIETIES}

Alba. Splendid pure white flowers.

Atropurpurea. Deep purple.

Crimson. Rich, dazzling color

Rosea. Soft rosy pink.

Scarlet. Bright and showy.

Striped. Many pretty colors

Grandiflora. Finest mixed.

\section{NA NA GOMPACTA PHLOX}

Superior bedding plants, of neat, compact habit, growing but 6 inches high and of ten a foot in diameter, with large heads of brilliant-colored flowers.

Defiance. Very bright scarlet.

Fireball. Handsome dark red.

Hortensiæflora. Rose.

Snowball Pure white.

Splendens. Crimson, white eye

Nana compacta. Finest mixed

the Phlox nana compacto entrain of

of colors. $\frac{1}{2} \mathrm{ft}$. Choice Mixed.

Star of Quedlinburgh. Pretty star-shaped flowers. Finest Mixed

Decussata. Hardy perennials, bearing large trusses of bright-colored flowers. $2 \mathrm{ft}$. Finest Mixed . .

PLATYCODON. See Wahlenbergia.

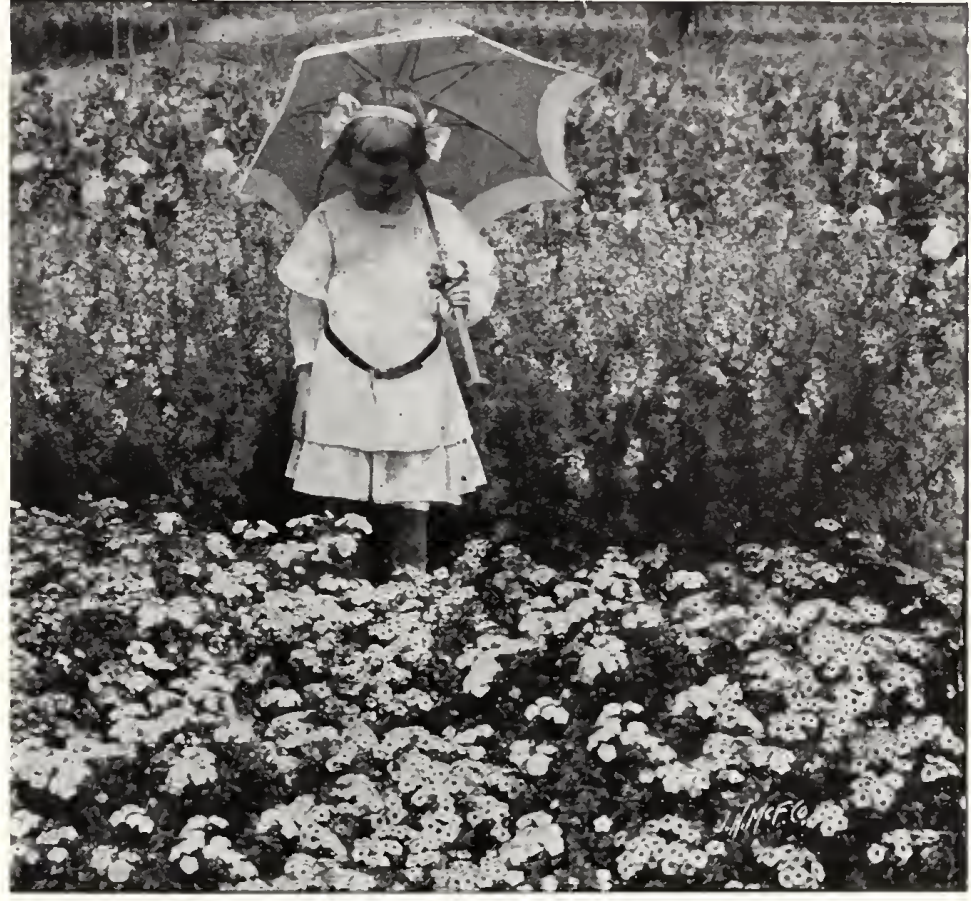

Phlox Drummondi nana compacta

\section{Primula (Chinese Primrose)}

The Chinese Primrose is one of the favorite pot-plants for winter blooming, cither in the house or conservatory. The fringed, richcolored flowers of very large size and handsome appearance, are in constant bloom throughout the greater part of the winter. Sow the seed from April until June. 9 inches.

Chinensis fimbriata, Giant-Flowered Fringed. A magnificent strain for exhibiting. The flowers of gigantic size, finest form and most exquisite colors, are thrown well above the Pkt. foliage. Mixed

Chinensis fimbriata, Finest Fringed Mixed

Chinensis stellata (Star Primrose). Very pretty, free-blooming plants for decorative purposes, with graceful spikes of starshaped flowers borne well above the foliage

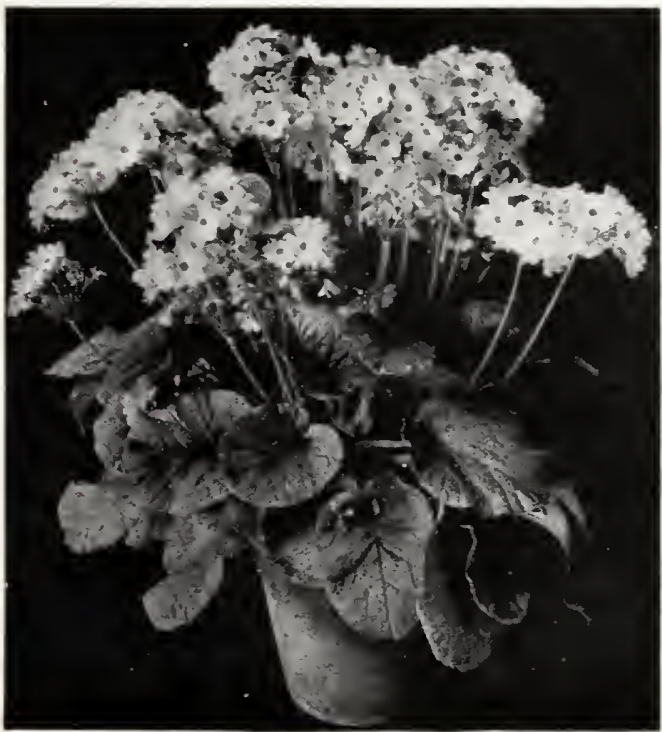

Primula obconica grandiflora
Obconica grandiflora. Splendid free-blooming hybrids, bear- Pkt. ing large clusters of flowers three mont hs after sowing. $1 \mathrm{ft}$. Obconica gigantea. An improved strain of the above, with extra-large flowers and comprising many beautiful shades and
colors. Kewensis. A new and charming acquisition to the Primula fam25 ily making very fine housc plants for winter blooming. The bright yellow flowers are fragrant and produced in whorls along the full length of the stem, which adds to their beauty and attractiveness. Sow seed early in spring. 15 inches.

\section{HARDY PRIMROSES}

Auricula. This half-hardy perennial blooms profusely early in spring, affording a splendid display of richly marked fowers. Choice Mixed. Pkt. $10 \mathrm{cts}$.

Elatior (Polyanthus).

These well-known per-

ennials are not perfectly

hardy, but if protected

in a coldframe during

the winter, make excel-

lent bedding plants for

spring blooning. The

beautiful, various - col-

ored flowers are marked

in the most striking manner and succecd best in partial shade. $1 \mathrm{ft}$.

Finest Mixed. Pkt. 10 cts.

Gold Laced. Pretty bright-colored flowers. Pkt. 10 cts.

Vulgaris (English Primrose). Yellow; fragrant. Pkt. 10 cts.

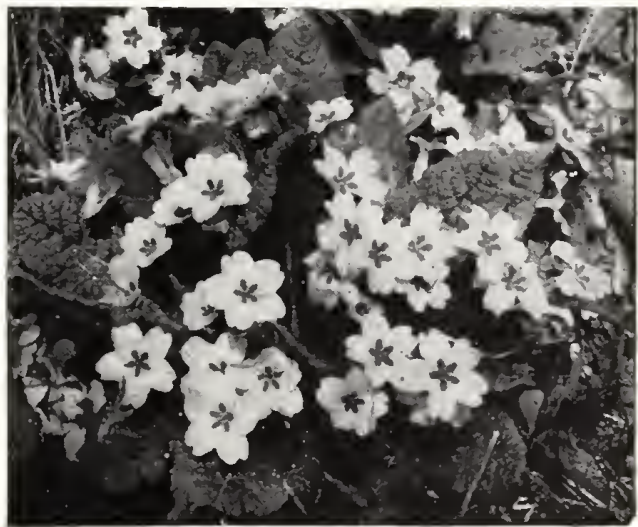

Primula elatior (Polyanthus) 


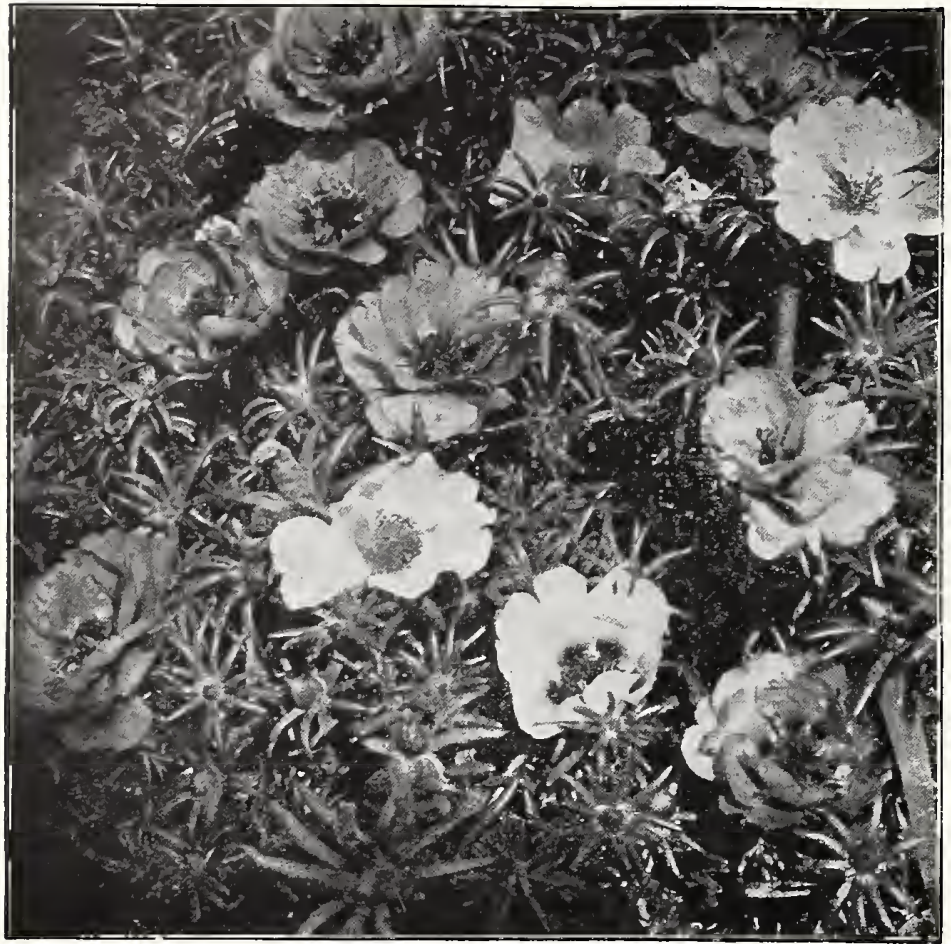

Portulaca, Single Large-Flowering

RHODANTHE. The pretty rose and white everlast- Pkt. ing flowers of this hardy annual are prized for winter bouquets. They succeed best in light soil. $1 \mathrm{ft}$.

Manglesii. Bright rose; free-flowering ........\$0 05

Mixed. Several colors..................... 05

\section{RICINUS (Castoreoil Bean)}

Semi-tropical plants of large growth, mainly raised for their ornamental foliage. As centerpieces for beds of cannas and caladiums, or even when planted alone, they are very imposing. Pkt. Oz.

Borboniensis arboreus. Green-leaved; $15 \mathrm{ft} . \$ 0 \quad 05 \$ 0 \quad 15$

Cambodgensis. Splendid for groups; maroon

foliage, black stcms. 5 feet.....................
Communis (Castor-oil Plant). Green leaves.

.............. $05-15$

Gibsoni. Deep reddish violet. $5 \mathrm{ft} \ldots \ldots \ldots \ldots 05 \quad 15$

Panormitanus. Enormous dark brown leaves, often 3 feet in diameter, and blue-powdered

stems; very striking.....................

Zanzibarensis. Plants attain a height of 12
to 15 feet and have remarkably large leaves of green, purple and bronze ................ 05

Finest Mixed. Many varieties.

\section{RUDBEGKIA}

Bicolor superba. Free-flowering annual with bright Pkt. yellow petals surrounding a dark brown disc. $2 \mathrm{ft} . \$ 005$

Bicolor superba semiplena. A double-flowering type of the preceding. It is easily grown, blooms very freely and from July until frost is covered with large, semi-double, golden yellow flowers. H. A.

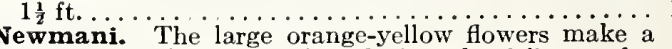
fine display in the garden during the fall months. Hardy perennial. $2 \frac{1}{2} \mathrm{ft}$.

\section{POR'TULACA}

There are few flowers that make such a dazzling display of color in the bright sunshine as a bed of Portulacas. It is not an unusual sight to see thousands of blossoms open at a single time, and ranging as they do through so many differcnt shades. A light, dry soil and above all a sunny position is to their advantage. Sow the seed broadcast, very shallow in the open ground in May, and after once sown they usually resow themselves. H. A. $\frac{1}{2} \mathrm{ft}$.

\section{SINGLE LA RGE-FLOW ERING}

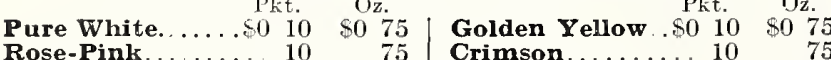

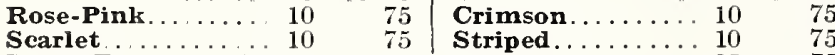
Large-Flowering Single Mixed ................. $05 \quad 75$ Collection, one pkt. each of above 6 separate colors, 40 cts.

\section{DOUBLE LARGE.FLOW ERING}

Pure White Pkt.

Scarlet. \$0 $10 \mid$ Golden Yellow 10 Rose-Pink

Pkt.

\section{PYRETHRUM}

Fine, hardy plants blooming in May and June; valuable alike for cutting and bouquets. H. P.

Roseum hybridum, Comet-Flowered. The single Ptt. double flowers of this new hardy Pyrethrum measure 2 to 3 inches across and, unlike the old variety, the petals are attractively curled and twisted. Excellent for cutting. Mixed Colors $\$ 015$ Roseum hybridum grandiflorum. Single daisy-like flowers borne on long stems, 2 fcet or more in length; fern-like foliage. 10 Roseum hybridum, fl. pl. Handsome double flowers of white, pink and all shades of red....

Aureum (Golden Feather). Fine for edging; golden yellow foliage. $1 \mathrm{ft}$.

Aureum selaginoides. Finely cut, fern-like yellow foliage... 05

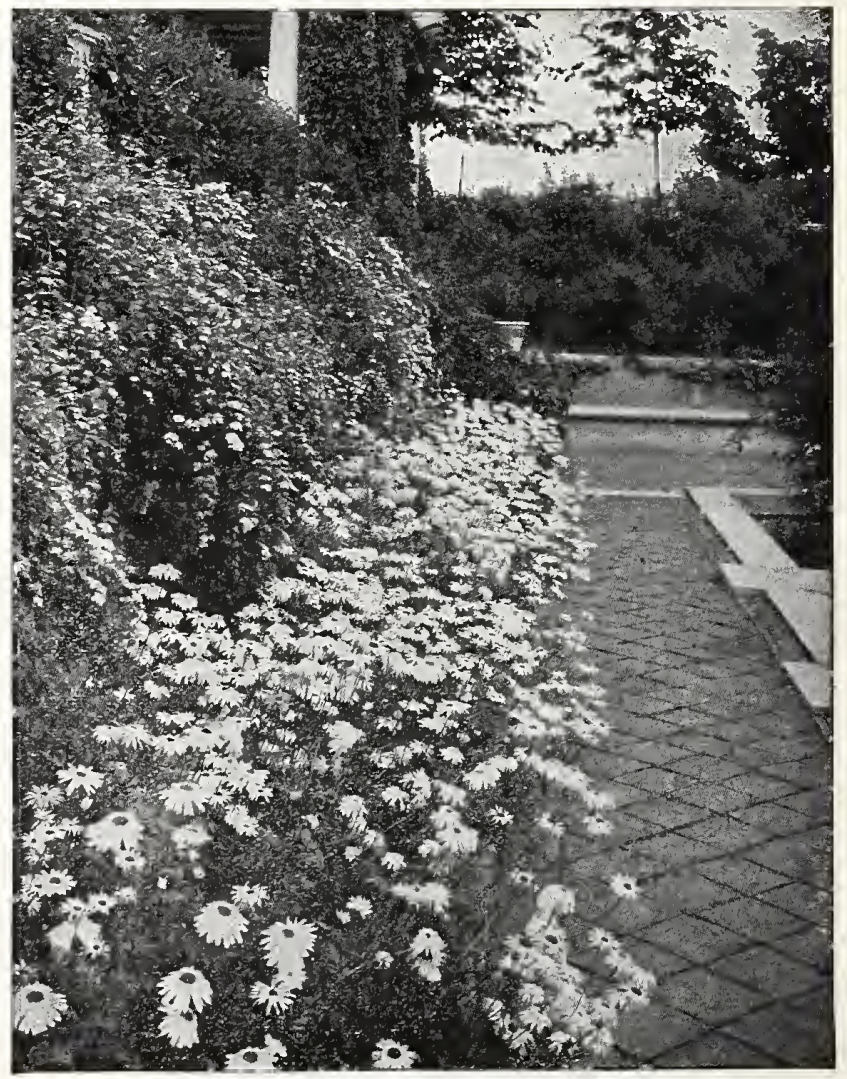

Pyrethrum, Roseum hybridum grandiflorum 


\section{H. BRUNJES \& SONS}

\section{SALVIA (Fire Plant)}

For an effective display of brilliant red-eolored flowers, the Salvia is in a class by itself. It is one of the leading plants for bedding, forming oval bushes 2 to $3 \mathrm{fcet}$ high, which during the late summer and fall months are ablaze with fiery red flowers. To have plants for setting out in May, the seed should be started in February or March and kept in a warm place. H. H. P.

Bonfire. (Clara Bedman). One of the fincst and most popular Salvias for Bonfire. bedding. The plants grow into compact oval bushes and are almost Pkt. hidden by the long spikes of brilliant searlet flowers. $2 \frac{1}{2} \mathrm{ft} \ldots \ldots \ldots, \frac{1}{4} \mathrm{oz} .75 \mathrm{c} \ldots .5010$

Ball of Fire. A dwarf early-blooming variety with large spikes of dazzling searlet flowers. The plants, while not nore than 2 feet high, are continually ablaze with flowers from July until late in fall.................

Zurich. This charming Salvia is of compact growth and particularly fine for

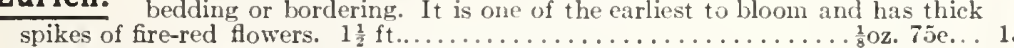
Splendens. A tail-growing, free-blooming variety with large spikes of brilliant scarlet flowers. Makes a very effective bed. $3 \mathrm{ft} . . . \ldots \ldots \ldots \ldots \ldots 1 / 40 \%$. $60 \mathrm{e} .$.

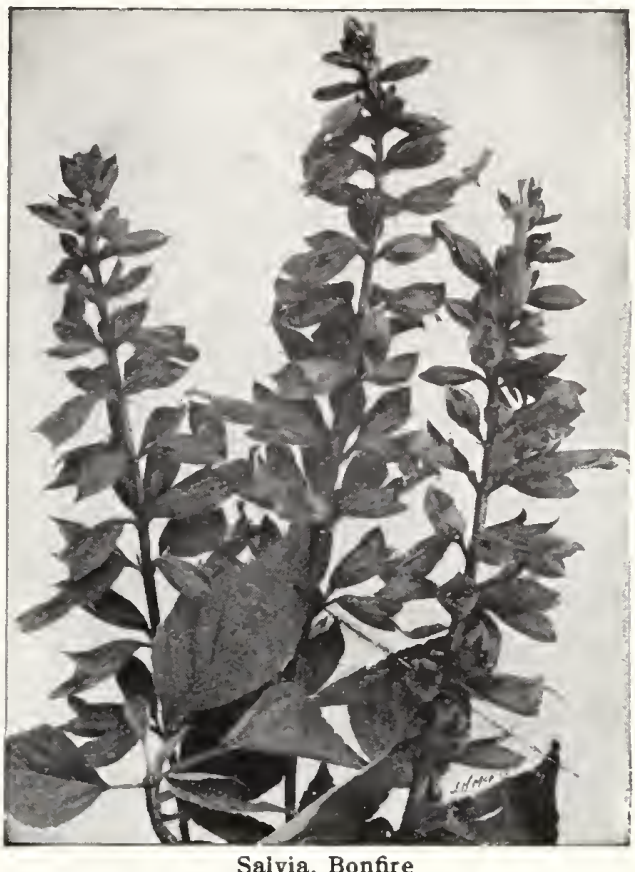

\section{SA I.PIGI,OSSIS}

Popular gardetu aunuals of easy culture, growing about $1 \frac{1}{2}$ teet nigh. The open flowers, similar to petunias, are marked with the most beautiful colors. Splendid for cutting.

Large-Flowering. Finest mixed.

so 10

Emperor. The flowers are rich and velvety in appearance, with wide-open throats penciled and reined with gold.

\section{0}

SANVITALIA procumbens, th. pl. A charming dwarf annual, useful for small beds, edges or baskets; and covered all summer with double, bright-yellow flowers. The plants grow about 6 inches high and like verbenas are of trailing habit and

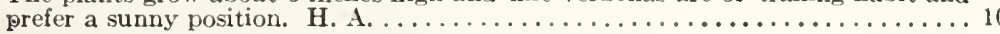

RELIABLE SEEDS

\section{SGABIOSA (Mourning Bride)}

A favorite hardy annual succeeding well in almost any soil. The double, long-stemmed flowers are produced freely all summer and for cutting or bouquets will be found invaluable. The plants of the large-flowering Scabiosa grow about 2 feet high while those of the dwarf variety are not more than half that height. From seed sown outdoors in May, plants begin blooning about July, but if convenient, sow indoors in March, and enjoy a longer season of bloom.

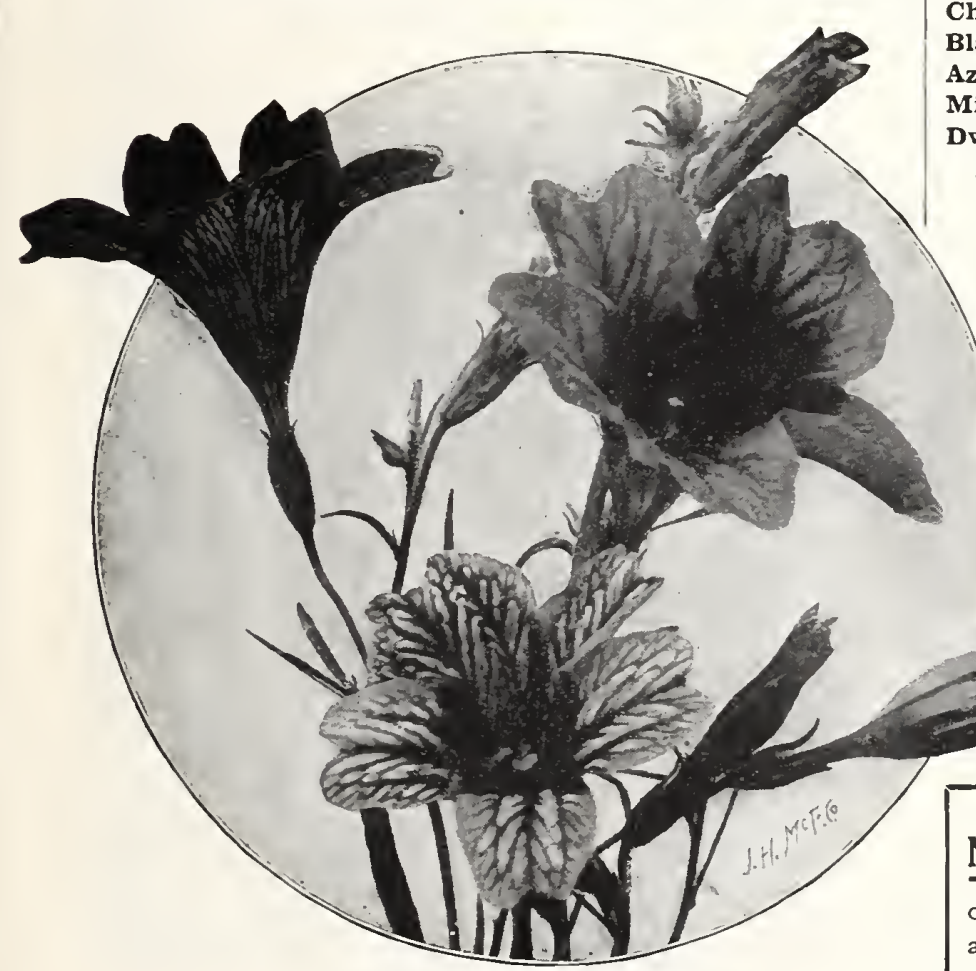

Salpiglossis, Large-Flowering

\section{DOUBLE LARGE. FLOWERING SGA BIOSA}

Our customers would do well to try some of these lovely large flowering Scabiosas. They are easily grown, extremely pretty and from a small patch in the garden an abundanee of flowers may be had until frost. The flowers are borne on long stems, very double and splendid for bouquets and vase deeoration.

White......

Pkt.

Rose.

Cherry-Red.

Black-Purple

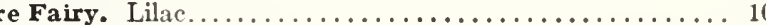

Mixed................................ 75c... 10

Dwarf Double Mixed. Of dwarf, compact growth not exceeding

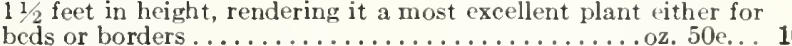

Caucasica. A handsome hardy perennial for cutting. The bushes are of spreading form, about 3 feet high and bear many pretty lilac-blue flowers from 2 to 3 inches in diameter on long stems

\section{SGIIILAN'TIICS (Butterfly Flower)}

Pretty garden plants, blooming trcely and covered with bright, gay-colored flowers whieh are not unlike a butterfly in appearance, and, from their range of rich and handsome colors, are often ealled "the poor man's orehid." They grow from $1 \frac{1}{2}$ to 2 feet high, and bloom in early summer. Pkt Mixed Colors

Wisetonensis. This large-flowering strain is exceptionally beautiful, and when in bloom the plants, with their multitude of white- and rose-spotted blossoms, present a wonderful sight. A most desirablc plant for pot-culture, blooms in profusion during early spring. $1 \frac{1}{2}$ fcet.

SEDUM coruleum. (Stonecrop). Charming little plants with bright blue flowers, doing best in light soil. Fine for roekeries. H. A. ${ }_{4}^{\frac{1}{4} \mathrm{ft} \ldots \ldots, 10}$

NASTURTIUMS, When planning your garden this spring do not forget to reserve space for a bed or border of our large-flowering Nasturtiums. They are always attractive and very pretty for table decoration. 


\section{H. BRUNJES \& SONS

SENSITIVE PLANT (Mimosa pudica). Very interesting plants, as the Pkt. leaves fold up when touched. Annual.

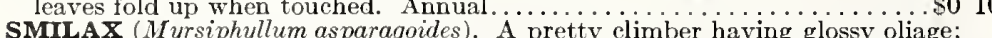

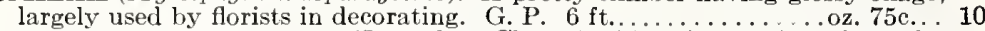
SOLANUM Capsicastrum (Jerusalem Cherry). Very interesting plants for greenhouse or window decoration. Plants are of dwarf branching habit and

their scarlet berries are very attractive. T. P. $1 \mathrm{ft}$.

SNAPDRAGON. See Antirrhinum.

\section{Stocks}

\section{Larǵe-Flowering Dwarf Ten-Weeks}

For beauty, dazzling effect, and long continuance of bloom these large-flowering Stocks are unsurpassed. They are superior for bedding and pot-culture and largely grown by florists and also in the home garden. The plants are of dwarf, compact growth, about 12 to 15 inches high, while the flower-spikes are large and double, delightfully fragrant, and produced in endless profusion all summer. A wonderful range of colors is represented in this class. Our strain produces a large percentage of double flowers.

Light Blue.

Bright Rose.

Blood-Red.

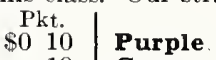

10 Canary-Yellow.

10 Dwarf Ten-Weeks. Mixed colors.

Pure White.

\section{Giant Perfection Ten-Weeks}

This beautiful perpetual-blooming Stock grows about $1 \frac{1}{2}$ feet high and bears large spikes, thickly studded with rosette-like blossoms. For cutting this is considered one of the best, being of rather tall, branching growth, with one large central spike and many smaller side branches. Very early, fragrant, and valuable alike for greenhouse or garden. Brilliant Rose

Light Blue

Pkt.

Finest mixed.

$\$ 010$

10

Fiery Crimson.............

Pkt.

\begin{tabular}{ll}
4 \\
Oz. $\$ 1 \ldots$ & 10 \\
\hline $1 \ldots$ & 10
\end{tabular}

STOKESIA cyanea (Cornflower Aster). This hardy perennial, with its large, l.vender-blue, cornflower-like blossoms, 4 inches or more across, makes one of the most effective plants in the garden. It grows about 2 feet high, is splen-

did for cutting, and continues in bloom from July until October........... 1

SUNFLOWER. See Helianthus.

SWEET AL YSSUM. See Alyssum.

SWEET ROCKET (Hesperis). A hardy perennial, growing from 2 to 3 feet

high and producing spikes of single, sweet-scented, purple and white flowers. Mixed.

05

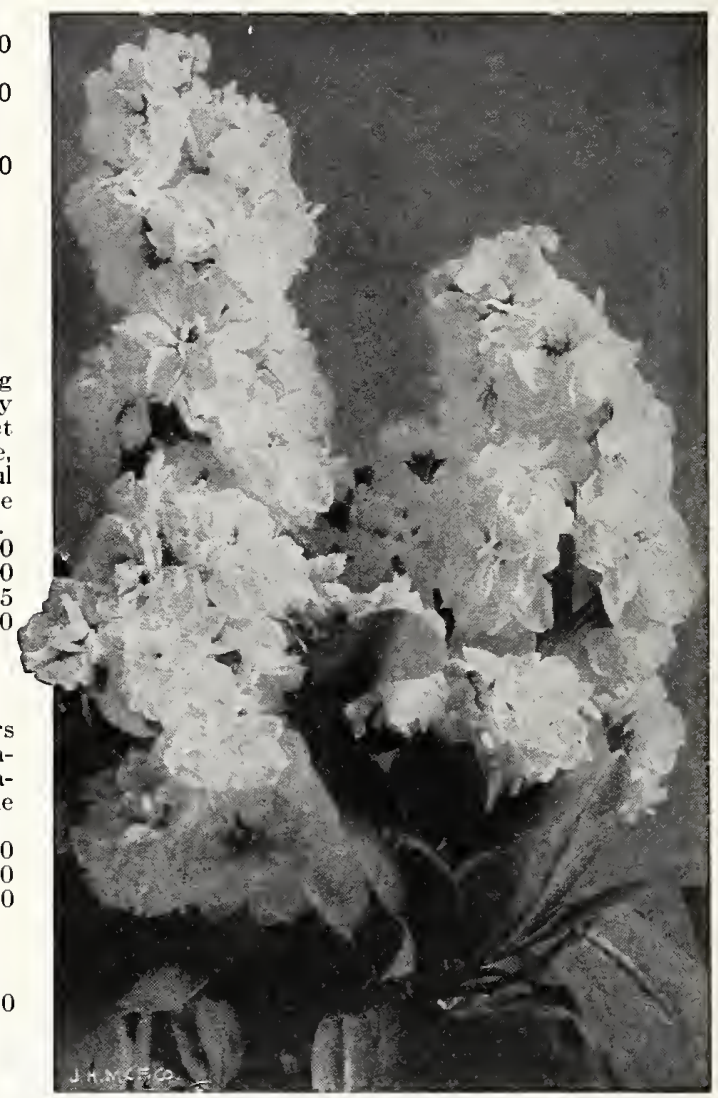

Stocks, Giant Perfection

SWEET SULTAN (Centaurea moschata). Hardy annuals with bright-colored flowers, on long, slender stems, which are splendid for Pkt. cutting and bouquets. $1 \frac{1}{2} \mathrm{ft}$. Mixed colors.

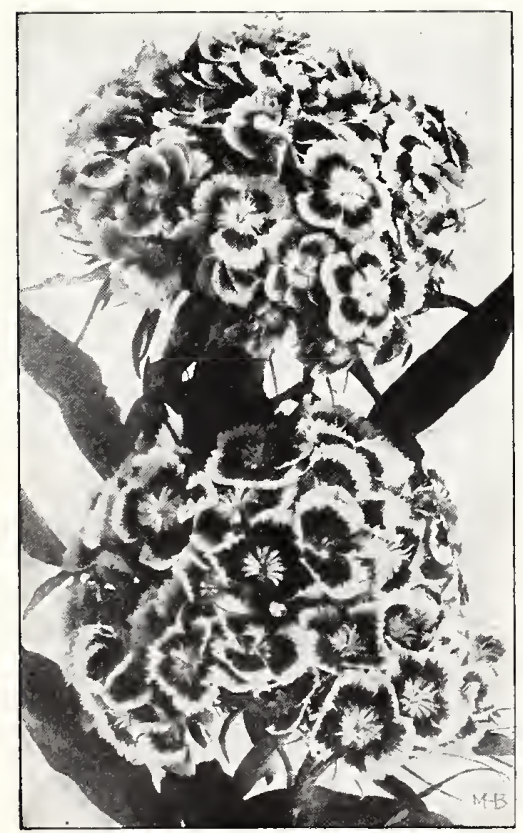

Sweet William, Dwarf Beauty

\section{SWEET WILLIAM (Dianthus barbatus)}

This ever-welcome hardy perennial, which has always been such a favorite in our grandmothers' gardens, is so well known that a description is hardly necessary. The plants grow from 1 to 2 feet high, and bear numerous heads of richly colored flowers, extremely fine for cutting and bouquets. Seed sown in July and August will produce blooming plants the second year. H. P. Brunjes' Dwarf Beauty. Finest of all Dwarf Sweet Williams. Our strain of Pkt. ever new, darge-flowering Sweet Williams is the finest bushy plants do not exceed 6 inches in height and the large heads of flowers appear in

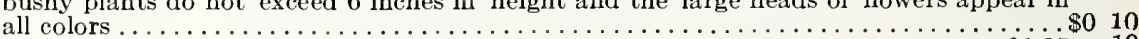

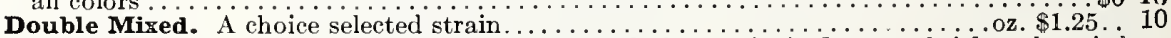

Auricula-flowered, Holborn Glory. Uncommonly large, single flowers of rich and varied

colors, distinctly marked with a white eye ...................

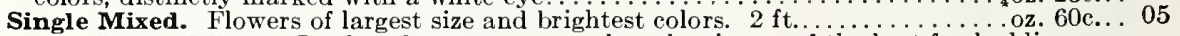
Single Dwarf Mixed. Its dwarf, compact growth makes it one of the best for bedding.. oz. $\$ 1.50 \div 10$

THUNBERGIA alata. A quick-growing, free-blooming annual climber especially desirable for hanging-baskets and vases. Pretty flowers of buff, white, and orange, with dark eyes.

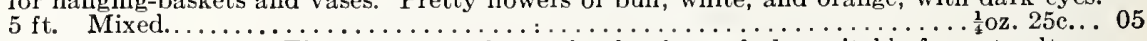

TORENIA Fournieri. Fine plants for the garden border and also suitable for pot culture.

They are extremely showy and abundant bloomers. Light blue flowers, with three dark

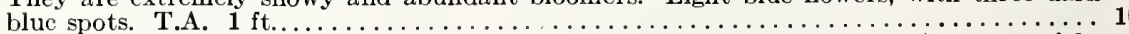

TRITOMA Uvaria grandiflora (Red-hot Poker Plant). Tall, long-blooming perennials,

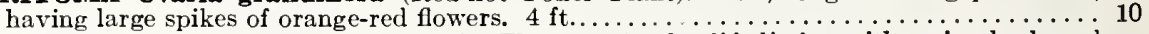
TROP AEOL UM canariense (Canary-bird Flower). A splendid climber with curiously shaped bright yellow flowers and fine-cut foliage. Blooms frecly from July until frost. H.H.A. 2 ft. Joz. $15 \mathrm{c} . .05$

VINCA (Periwinkle). Fine, free-blooming plants with glossy green leaves and bright rose and white flowers. They are excellent for bedding and if the seed is sown carly they will bloom the first year. H. H. P. 2 ft. Mixed Colors.

vioLA odorata (Sweet Violet). A well-known hardy perennial with sweet-scented, blue flowers. The seed of this variety is slow in germinating. $\frac{1}{2} \mathrm{ft} . \ldots \ldots \ldots \ldots \ldots \ldots \ldots \ldots$

VIRGINIAN STOCK. Favorite little plants, 8 to 10 inches high, which are admired for their charming bright-colored flowers. H.A. Mixed..................... 05 


\section{H. B. \& SONS' MAMMO'TH VERBENA}

Our choice strain of Mammoth Verbena, one of the most effective bedding plants, is unsurpassed for its brilliant colors and immense-size flowers. The plants, of spreading growth, are just covered with large heads of beautiful, colored flowers until late in autumn. Best results are obtained by sowing the seed early in the house or hotbed, but outdoor sowings may be made also in May. Annual. $\frac{1}{2} \mathrm{ft}$.

\begin{tabular}{|c|c|}
\hline Pkt. & Pkt \\
\hline & \\
\hline 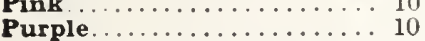 & Mixed $\ldots \ldots \ldots \ldots \ldots \ldots$ oz. 50 c.. 10 \\
\hline
\end{tabular}

M. H. B. \& Sons' Invincible. Remarkable for the size of its and diversity of color. A grand strain saved from a large collection of named varieties. Mixed colors ................. $\frac{1}{8} \mathrm{oz} .75 \mathrm{c} .$.

Hybrida, Finest Mixed. Contains many colors; flowers of medium size. Very free flowering ............................ $\$ 1.05$

Lemon Verbena (Aloysia citriodora). The light green leaves of this variety are sweetly scented and extensively used in bouquets. It may be planted in the garden for the summer and is very nice for the bouse or conservatory during the winter. $2 \mathrm{ft}$.

WAHLENBERGIA (Platycodon). Handsome, hardy perennial bearing a profusion of large, bell-shaped flowers. For mixed beds and herbaceous borders these Chinese Bellflowers will be found very useful. Prefers a rich soil. 2 to $3 \mathrm{ft}$. Grandiflora, Mixed. Blue and White

\section{WALLFLOWER}

The Wallfower is particularly noted for its sweet fragrance and deserves to be more popular than it really is. To obtain fine plants for setting out in early spring, the seed should be sown in July and August, and the plants wintered over in coldframes. The plants are of strong, sturdy growth, well-branched and from $1 \frac{1}{2}$ to 2 feet high, rendering them most suitable for bedding. H. H. P.

\section{SINGLE LARGE.FLOW ERING}

Tom Thumb, Black-Brown. Plants dwarf and compact; rich, dark Pkt. brown flowers. 15 inches.. . . . . . . . . . . . . . . Single Mixed. Fine mixture. oz. $50 \mathrm{c} . \ldots 05$ Single Annual, Paris Earliest. Blooms the first year from seed sown in February and March. Light brown flowers.

Single Annual, Finest Mixed. All colors, including crcamy white, blood-red, golden yellow and brown. .

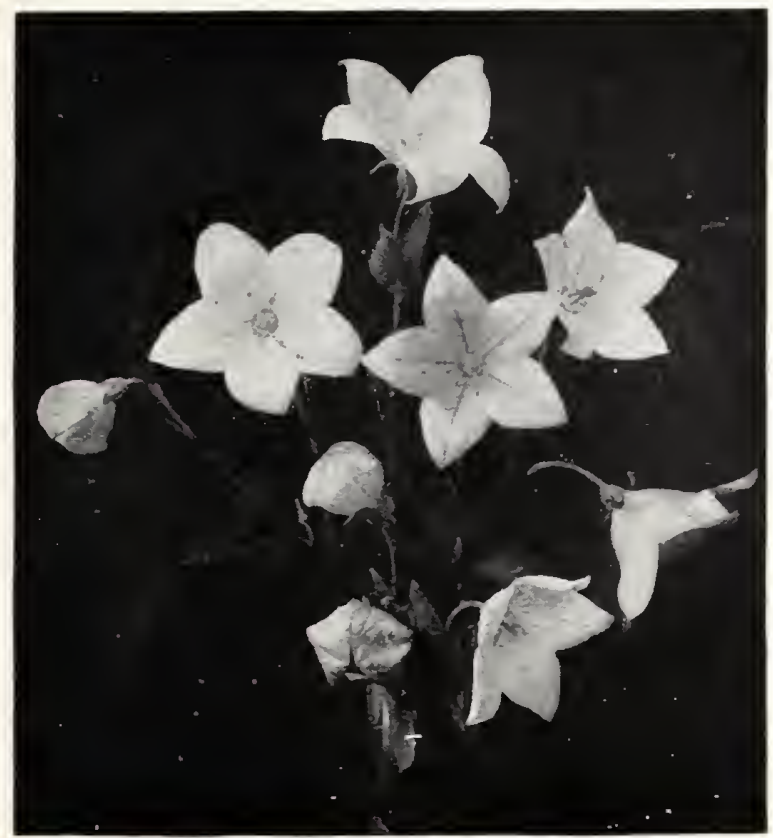

05

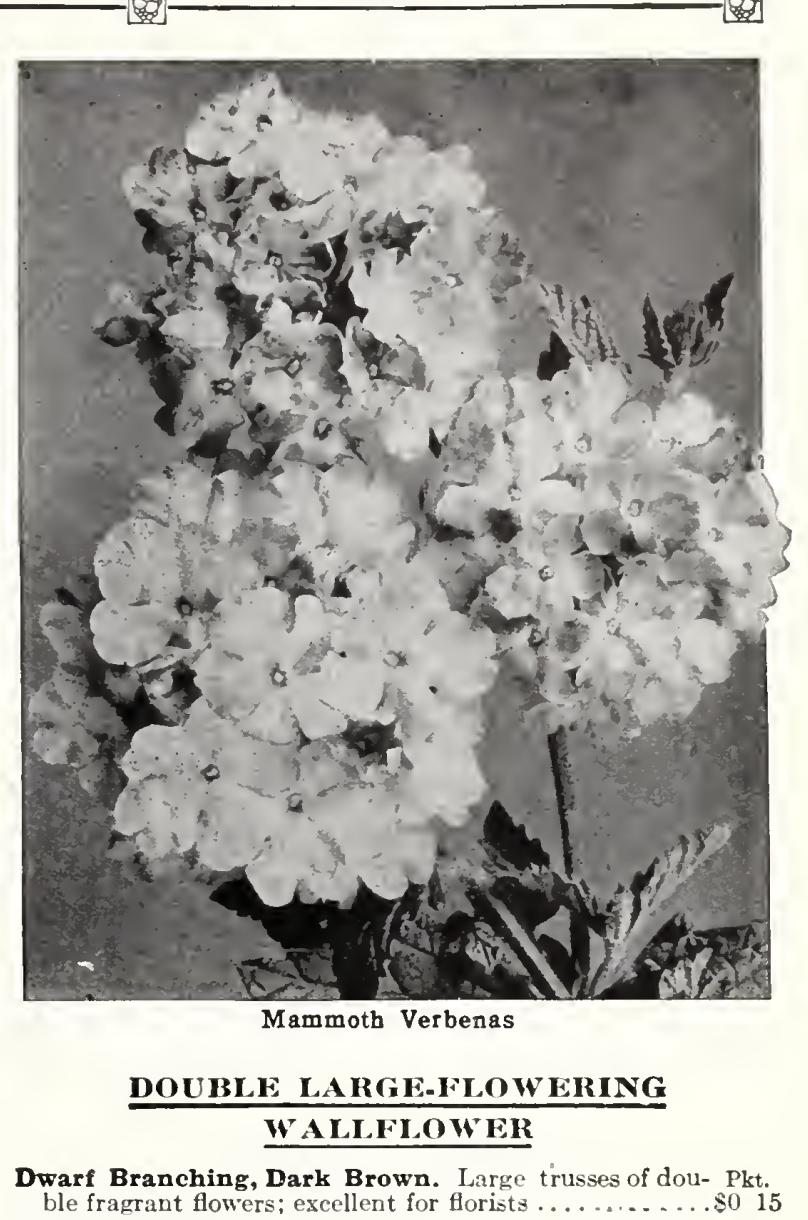

Branching, Dark Brown. Large trusses of dou- Pkt. ble fragrant flowers; excellent for florists ............ \$ 15 Dwarf Branching, Double Mixed. Crcamy white, canary-yellow, dark brown and violet-blue ..........

\section{WINTER-BLOOMING WALLFLOWER}

\section{(Cheiranthus Kezvensis)}

The flowers upon opening are sulphur-, then golden yellow and gradually change to purple-violet. Yery fragrant and in bloom from November until spring. Sow seed in May or June and when large enough transplant to the garden; repot in the fall (September) for winter flowering. Pkt., 15c.

WHITLAVIA. The plants grow about 15 inches high and produce Pkt. clusters of handsome cup-shaped blossoms. H. A. Mixed ........ s0 05 WILD CUCUMBER VINE. See Echinocystis.

XERANTHEMUM. A splendid "everlasting" for bouquets. An abundance of pretty, gracefully formed flowers of white, rose and purvle are borne on compact bushes about 2 feet high. Sow seed in the open ground in May. H. A. Mixed colors..................... 05

\section{WILD FLOWER GARDEN MIXTURE}

Although better results are obtained from the sowing of separate flower secds, this mixture, which is composed entirely of annuals, is very useful for sowing among shrubbery, along driveways or places that would otherwise look barrell. It will produce a beautiful and gay effect all summer and supply plenty of flowers for bouquets. Sow the seed broadeast outdoors during May and June. Pkt. 10 cts., oz. 30 cts., $1 / 1$ lb. $\$ 1$.

Wahlenbergis (Platycodon)

We have received many words of praise about our Asters. A fine collection of the best varieties will be found listed on pages 32,33 and 34 . 


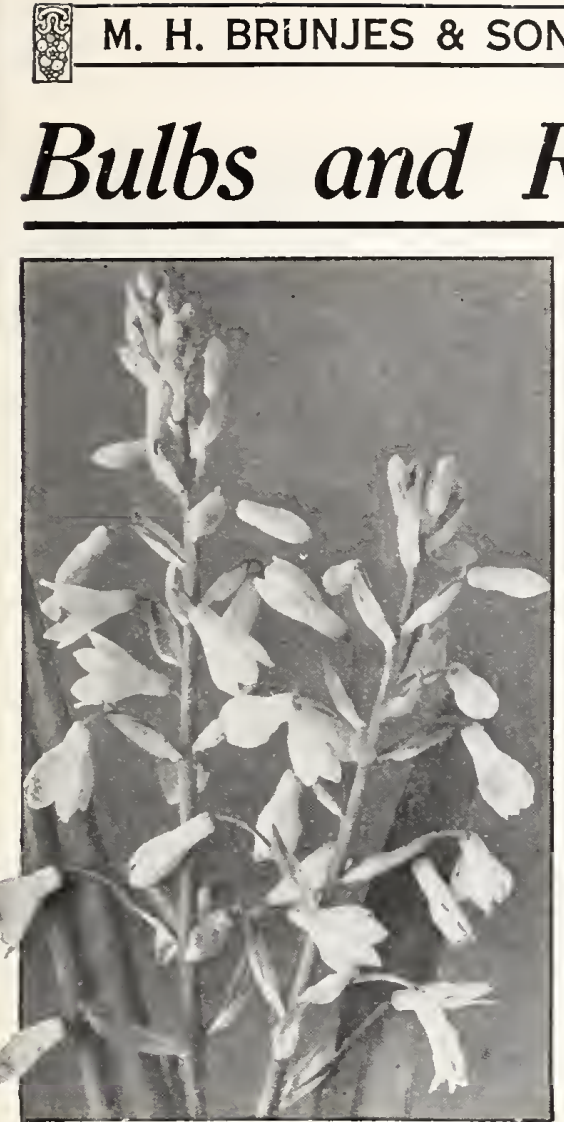

Hvacinthus candicans

\section{AMARYLLIS}

Giant Hybrid (Hippeastrum). Splendid plants for pots or windowboses, with large trumpet-shaped flowers ranging through virious shades of pink, white, and scarlet, some with beautiful markings and mottled throats. They are of easy culture and usually from four to six iarge perfect bloons are produced from each bub. Large Bulbs, 50 cts. each, s5 per doz. By mail, add 3 cts. each extra.

\section{GINNAMON VINE}

A hardy, rapid-growing climber with brient prcen, leart-shaped leaves and snall, snow-white cinnamon-scented flowers. Extra-large Bulbs, $10 \mathrm{cts}$. each, $\$ 1$ per doz+: postpaid, $\$ 1.10$.

\section{for Summer Flowers}

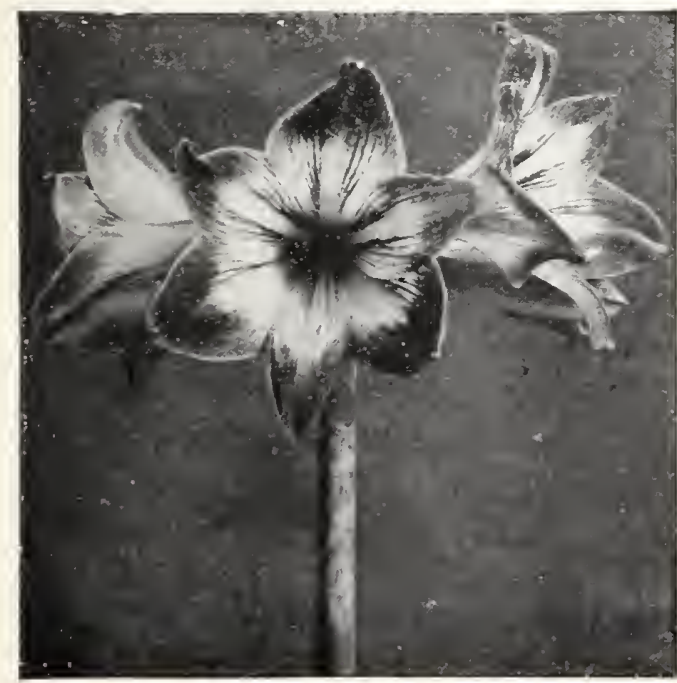

Amaryllis

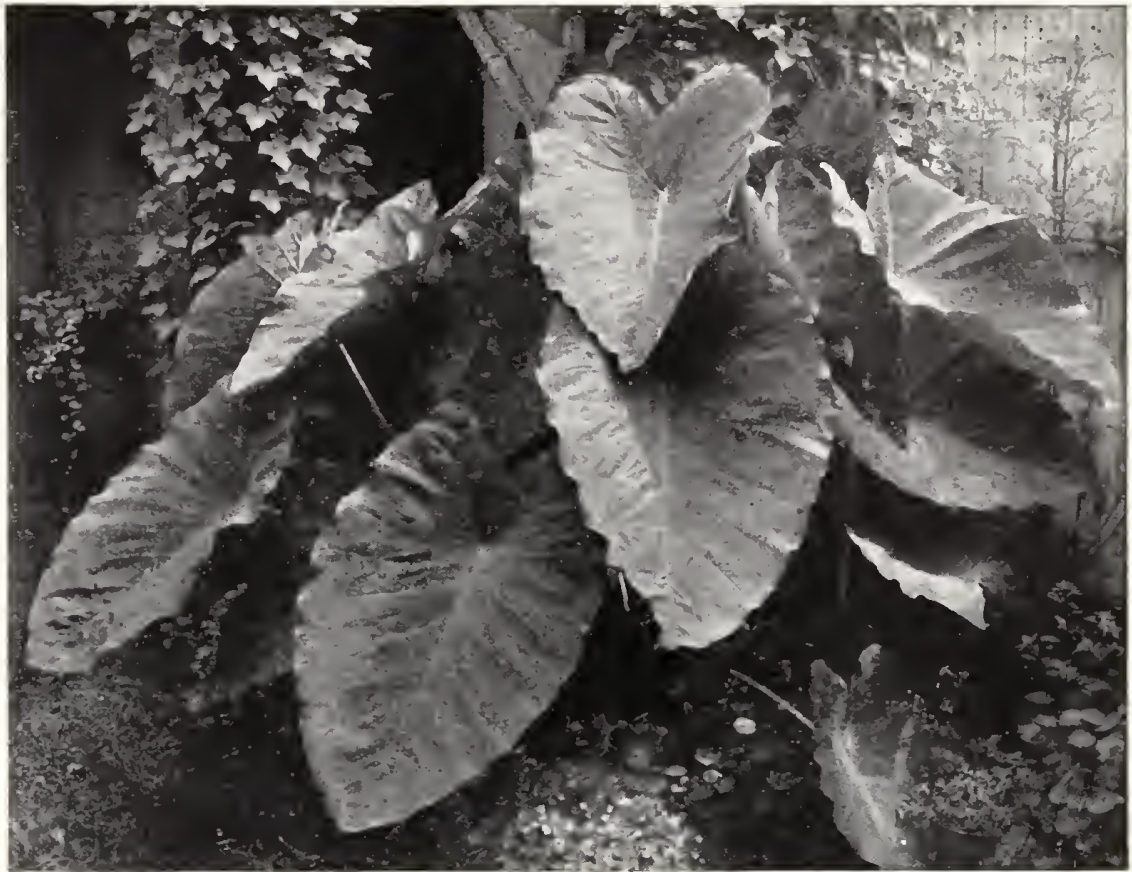

Caladium (Elephant's Ear)

\section{GALADIUM ESGULENTUM}

(Elephant's Eir)

When planted in beds or borders, the Caladium is very effective. The large, light green leaves are of enormous dimensions, of ten measuring 3 feet long and 2 feet in width. Grows in any good garden soil.

\section{Large Bulbs}

Extra-Large Bulbs

Jumbo, or Mammoth Buibs.

Each Doz $25 \quad 25$ Above shipped by express, not prepaic

\section{MADEIRA VINIE}

This popular, quick-growing climber has thick, glossy green leaves and fragrant, feathery, white flowers. Large Bulbs, $10 \mathrm{cts}$. each, $\$ 1$ per doz.; postpaid, $\$ 1.10$.

\section{HYACINTHUS GANIICANS}

Pure white, hell-shaped flowers are suspended gracefully from the long, slender spikes which grow from 3 to 4 feet high. Of ten 20 to 30 flowers have heen counted on one stem. Very effective when planted in clumps. Large Bulbs, 10 cts. each, s 1 per doz. If by parcel post, add postage at zone rate. Weight, 3 lbs. per doz.

\section{I R I Y CLIMBEIRS}

CLEMATIS Jackmanii. Large, purple flowers. Strong, 2-year-old, field-grown plants. 60 cts. each.

CLEMATIS paniculata. Small, white, fragrant flowers. Strong, 3-year-old, fieldgrown plants. 40 cts. each.

\section{DIELYTRA SPECTABILIS (Bleedinǵ Heart)}

This well-known, favorite flower is perfectly hardy and will grow in any part of the garden, even in the shade. It grows about 2 feet high, blooms early, and has long racemes of heart-shaped pink flowers. $50 \mathrm{cts}$. each; by mail add $8 \mathrm{cts}$. each extra. 


\section{H. BRUNJES \& SONS BROOKLYN, N. Y.}

\section{RELIABLE BULBS}

\section{Brunjes' Cannas}

Cannas arc, without doubt, one of the best and most popular of all plants for bedding. They are largely planted in the public parks of Brooklyn, where they are admired from early summer until killed by frost. The plants grow from 3 to 6 feet high, have massive green and bronze foliage and large, handsome flowers measuring up to 7 inches aeross. Roots should not be set outdoors before May.

IF BY PARCEL POST, ADD POSTAGE AT ZONE RATE. ONE DOZ. WEIGH 3 LBS. ADD 3 CTS. EACH FOR SINGLE ROOTS

Gladiator. A strong, rigorous-growing, green-leaved Canna ladiator. about 4 to 5 feet high, having bright yellow, crimson-spotted flowers, $10 \mathrm{cts}$. each, $\$ 1$ per doz.

Golden Eagle. One of the best golden yellow Cannas for bedshowy trusses of flowers are produced early and freely well above the grecn foliage. 10 ets. each, $\$ 1$ per doz.

Hungaria. A lovely new Canna and one of the very best pink soft blush-pink and are produced freely until late fall. Green foliage. $3 \frac{1}{2}$ feet. $10 \mathrm{cts}$. each, $\$ 1$ per doz.

King Humbert. Of all the varicties, this one is especially spceimens. The superb orange-scarlet flowers are of enormous size, and, with the massive bronze foliage, few Cannas are more effeetive. 5 feet. $10 \mathrm{cts}$. eaeh, $\$ 1$ per doz.

Queen Charlotte. The foliage is dark green, whilc the crimbroad band of bright yellow. 4 feet high. $10 \mathrm{cts}$. each, $\$ 1$ per doz.

Pennsylvania. A superior, grecn-leaved, orehid-flowered flowers, often measuring 6 inches in diameter. Free bloomer. 6 feet. 10 cts. each, $\$ 1$ per doz.

The President. Superior in every respect to any other greenThe President. leaved red Canna. The flowers are of large size, bright glistening scarlet in color and produced freely on firm, upright stalks about 4 feet hígh. 15 ets. each, \$1.50 per doz.

Gaiety. An attraetive varicty having green foliage and growing feet high. Reddish orange, mottled with earmine

City of Portland. Another green-leaved variety with bcautiful City of Portland. Another green-leaved variety with bcautiful and makes a very pretty bed. $10 \mathrm{cts}$. each, $\$ 1$ per doz.

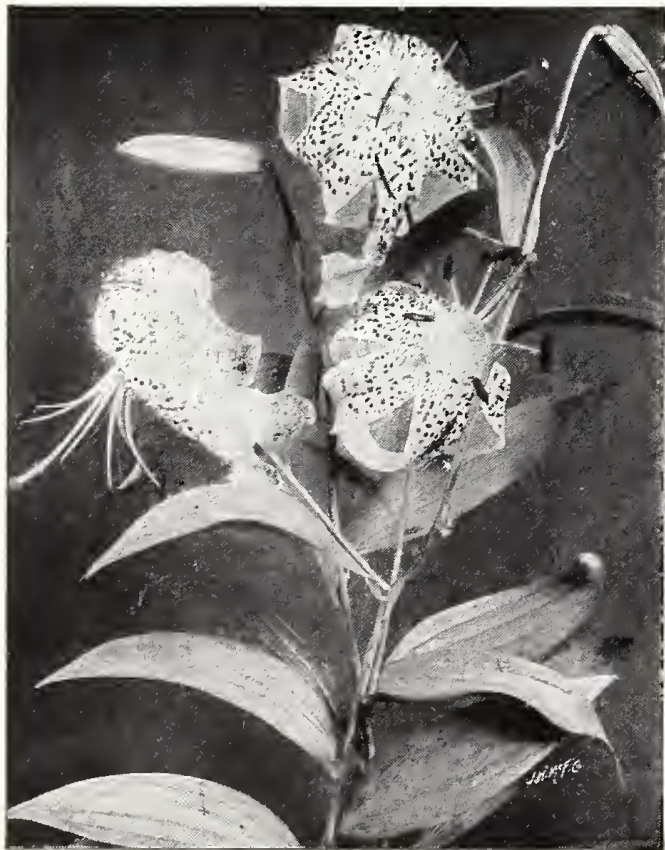

Lilium speciosum rubrum

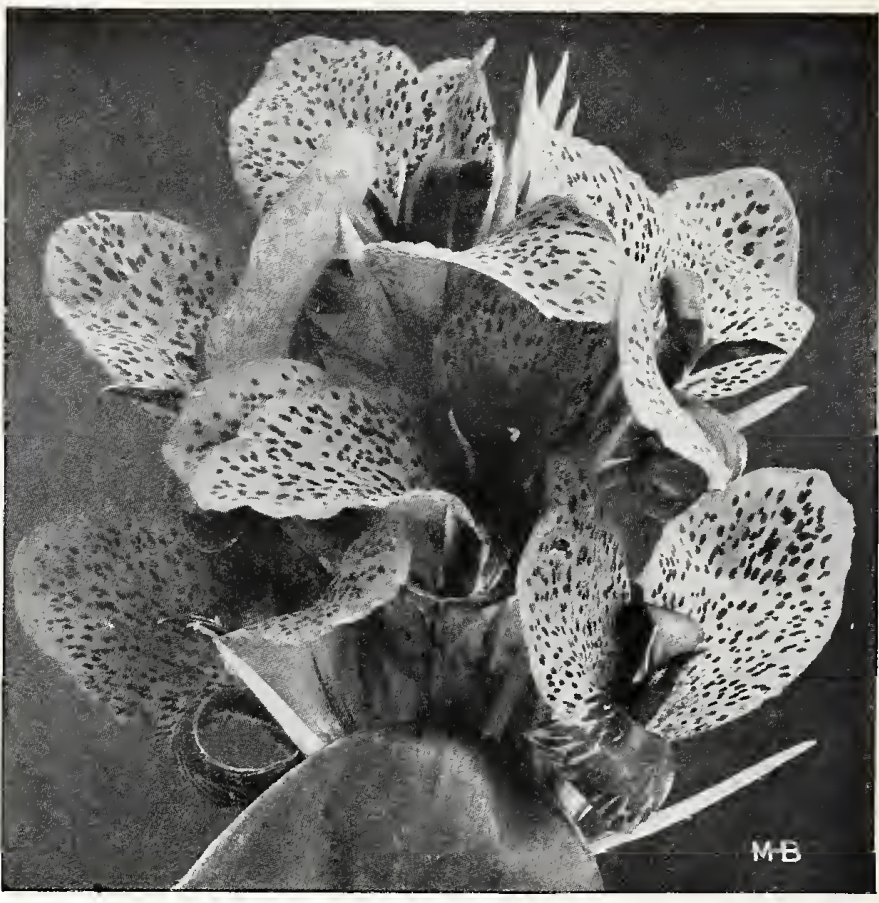

Canna, Gladiator

Venus. This is undoubtedly the daintiest of all Cannas. Its enus. pretty pink flowers are slightly tinted at the edges with creamy yellow. Green foliagc. $3 \frac{1}{2}$ feet. $10 \mathrm{cts}$. each, $\$ 1$ per doz. Wyoming. A beautiful orchid-flowered Canna growing almost 6 feet contrast with the purplish bronze foliage. $10 \mathrm{cts}$. each, $\$ 1$ per doz. Yellow King Humbert. A beautiful orchid-flowering Canna deep, rich ycllow, spotted with bright scarlet and equally as large as the well-known King Humbert. Green foliage. 4 feet. 10 cts. each, $\$ 1$ per doz.

\section{JAPANESE LILIES}

Lilies, with their stately growth and magnificent-colored flowers, many of them beautifully spotted, form a splendid appearance in the herbaceous border, where they should remain for years undisturbed. Plant as soon as the ground is open in spring. Set bulbs 6 inehes deep, placing a handful of sand at the bottom of each.

Auratum (Golden Banded Lily). Handsome flowers of pure white, freely spotted with erimson, having a broad band of rich yellow running through the center of each petal. Very fragrant and blooms the latter part of July. 35 cts. each, $\$ 4$ per doz.

Speciosum album. One of the hardiest garden Lilies, with fragrant flowers of purest white, blooming in August. 35 cts. each, $\$ 4$ per doz.

Speciosum Melpomene. A magnificent variety. Pure white flowers of immense size, heavily spotted with erimson. $35 \mathrm{cts}$. each, $\$ 4$ per doz.

Speciosum rubrum. Very pretty white Lilies thickly spotted with crimson. 35 cts, each, $\$ 4$ per doz.

Regal Large, white, swcet-seented flowers, slightly suffused with pink, with a Regal. eanary-ycllow center. Hardy and blooms in July. 4 feet high. 45 cts. each, $\$ 5$ per doz.

IF BY PARCEL POST, ADD 3 CTS. EACH EXTRA

\section{OXALIS (Summer-Flowering)}

Pretty frce-flowering plants, having clover-like foliage; extensively used for bordering. Bloom early and continuously throughout the summer. Plant bulbs 3 inches apart.

Deppei. White; mammoth bulbs. 25 cts. per doz., $\$ 1.50$ per 100 .

Shamrock. Rosy pink; mammoth bulbs. 25 cts. per doz., $\$ 1.50$ per 100 . 


\section{BRUNJES' SUPERB DAHLIAS}

Although of easy culture, Dahlias should be planted in an open position, where they have plenty of air and receive the full benefit of the sun. A deep, rich soil is also necessary. Begin planting early in NIay and until the latter part of June, placing the roots 3 feet apart and 4 inches below the surface. As the shoots appear, all but two or three of the strongest should be cut away.

If by parcel post add postage at zone rate. Weight, $1 \mathrm{lb}$. each.

\section{SHOW AND DECORATIVE \\ DAHLIAS}

Sagamore. Large, perfectly formed flowcrs of ambergold, shading to salmon-rose toward center. $50 \mathrm{cts}$. each.

Earl Williams. Brilliant crimson-scarlet, each petal tipped with white. A large Decorative Dahlia. $50 \mathrm{cts}$. each.

Dakota. The giant flame-colored flowers of this beautiful Deeorative variety are of perfect form. Splendid for exhibiting. $50 \mathrm{cts}$, each.

Dreer's White. An exceptionally fine Dahlia with large, glistening, snow-whitc flowers. The plants are quite dwarf, only 3 feet high, and noted for their free blooming, being filled with flowers until late fall. 35 cts. each, \$4 per doz.

Dreer's Yellow. Clear yellow; larger but otherwise similar to Dreer's White. $35 \mathrm{cts}$. each, $\$ 4$ per doz.

Golden Opportunity. A grand, free-blooming Dahlia for the garden. Large, ball-shaped flowers of rich buttercup-yellow. $50 \mathrm{cts}$. each.

Jersey's Beauty. All the good qualities of a perfect Dahlia are combined in this wonderful new introduction. The giant flowers are of the Decorative type, true pink in color, and produced early and freely on long, stout stems. 50 ets. each.

La France. A beautiful pink Show Dahlia for cutting; large, full, double flowers. $25 \mathrm{cts}$. each, $\$ 2.50$ per doz.

Le Grand Manitou. (Decorative.) One of the very best variegated or fancy varieties. Flowers 6 inches across, beautifully striped, blotched, and marbled reddish violet on white ground; occasionally the flowers are solid reddish violet. $35 \mathrm{cts}$. each, $\$ 1$ per doz.

Millionaire. Another Decorative Dahlia with beautiful, lavender-pink flowers of immense size and perfect form. $35 \mathrm{cts}$. each.

Jane Cowl. A sensational bronzc Dahlia shading to old-gold. The stems are excellent and flowers immense. A consistent prize-winner. $\$ 1.25$ each.

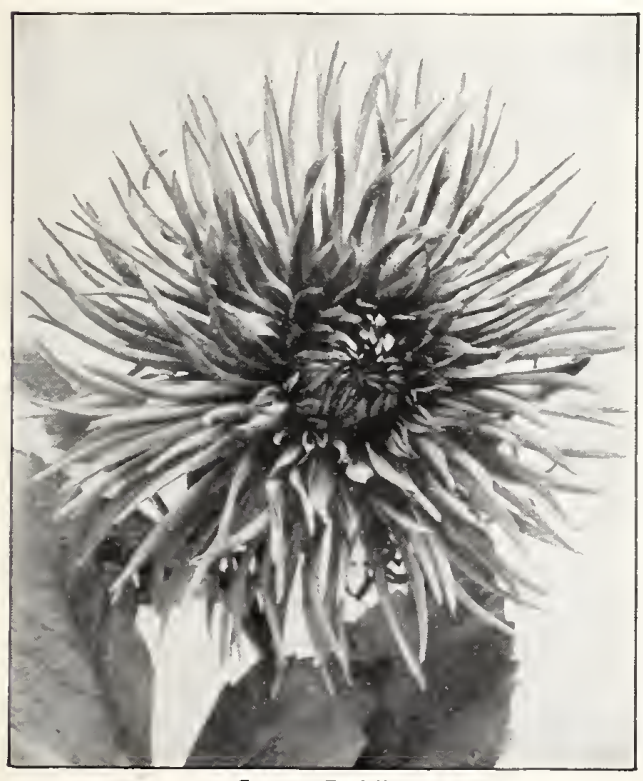

Cactus Dahlia

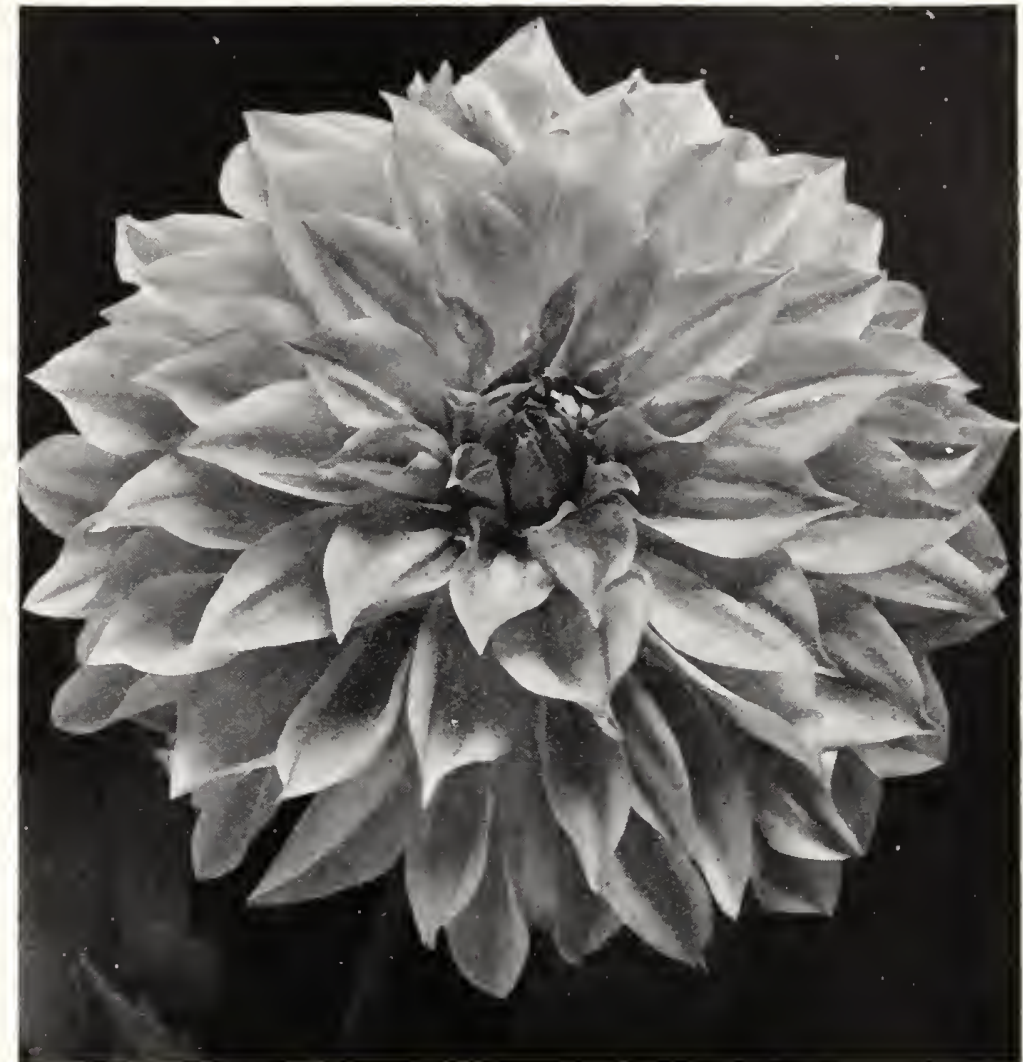

Decorative Dahlia, Mrs. Carl Salbach

Mrs. Carl Salbach. A splendid exhibition Dahlia of the Decorative type. The lavender-pink flowers measure 8 to 9 inches across. $50 \mathrm{cts}$. each.

Mrs. I. de Ver Warner. Without doubt the leading Decorative variety of its color - a beautiful mauve-pink. It bloons early and the perfcctly formed flowers are of the largest size. $50 \mathrm{cts}$. each.

Robert Treat. Similar in color to the American Beauty rose; exceedingly large flowers of the Decorative type. $75 \mathrm{cts}$. each.

Pride of California. The blooms, of immense size, are exceptionally fine for cutting. The best deep red Decorative Dahlia. 35 cts. each.

Sylvia. Large, double, pink flowers, shaded whitc toward the center. Splendid for cutting and vase decoration. 35 cts. each, $\$ 4$ per doz.

White Swan. Large, double flowers of purest white. $25 \mathrm{cts}$. each, 82.50 per doz.

Wm. Stark Smith. In attractive variety with large, golden yellow flowers, splashed scarlet. 35 cts. each, $\$ 1$ per doz.

\section{CACTCS DAIILIAS}

Countess of Lonsdale. One of the finest of the Cactus varieties, prized for its handsome, salmon-colored flowers, and unequaled for its abundance of bloom. 35 ets. each, $\$ 4$ per doz.

George Walters. A lovely hrbrid Cactus Dahlia, having brilliant salmon-pink flotiers. 35 cts. each, $\$ 4$ per doz.

Gladys Sherwood. One of the largest of this class; pure glistening white flowers. 35 cts. each, \$1 per doz.

Golden West. A pretty variety from California; rich golden yellow flowers 6 to 7 inches in diameter. 35 cts. each, $\$ 4$ per doz.

Springfield. Best described as an amaranth-red; very attractive for vase decoration. 35 cts. each, 84 per doz. 


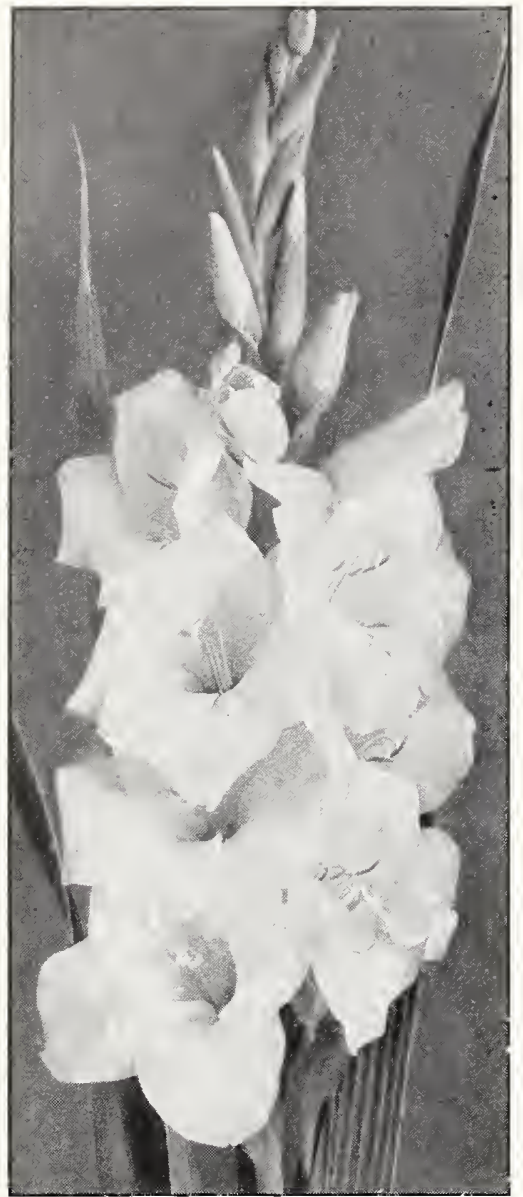

Gladiolus, America

\section{PEONIES}

One of the most popular hardy plants in cultivation today. They will stand the severest winter with little or no protection, and during June afford a display that words can hardly describe. Every garden should have one or more of these handsome plants which, year after year, grow more beautiful and of ten carry from twenty to thirty flowers. The flowers are of enormous size, perfectly double, sweetly scented and borne on long, stiff stems, which render them excellent for cutting. To obtain best results they should be planted in deep, rich soil, to which a iberal amount of well-decayed manure has been added, with a covering of about 3 inches over the top of the roots and left undisturbed. Each Double White.

Double Pink.

$\$ 0 \quad 50$

Double Red

BY MAIL ADD 10 CTS. EACH, EXTRA

\section{TUBEROSE}

The pure white double flowers form on long stems 3 feet high and are very fragrant. They usually bloom in September. To obtain best results do not plant bulbs before May 15.

Double Excelsior Pearl. $50 \mathrm{cts}$. per doz., $\$ 3.50$ per 100. Add postage at zone rates. One dozen weigh $11 / 2 \mathrm{lbs}$.

Mammoth Bulbs. 75 cts. per doz., $\$ 5.50$ per 100 . Add postage at zone rates. One dozen weigh $2 \frac{1}{2} \mathrm{lbs}$. per doz. each, $\$ 1$ per doz.

\section{FIFTEEN BEAUTIFUL GLADIOLI}

BY PARCEL POST, ADD POSTAGE AT ZONE RATE. ONE MAILED FREE. After years of careful improvement, the Gladiolus is today one of the most beautiful of all
ummer-flowering bulbs. Even in ordinary garden soil few will give such remarkable results with so little care. Bulbs should be planted 4 to 6 inches apart and 3 to 5 inches deep according to the

America. Undoubtedly one of the best and most largely planted pink Gladioli for cutting. stems and last remarkably well in water. $6 \mathrm{cts}$. each, $60 \mathrm{cts}$. per doz.

Alice Tiplady. A beautiful Primulinus variety. Brilliant orange-salmon flowers; very showy. Baron Hulot. A rare and lovely shade of dark violet-blue; exceptionally fine and decorative. Crimson Glow. A glowing velvety crimson shaded deeper in the center. Very large, open

Mrs. Dr. Norton. Silvery white flowers, tinged with pink, deepening toward the edges; lower petals primrose-yellow dotted pink. 10 cts. each, \$1 per doz.

Mrs. Leon Douglas. Begonia-rose, striped with fame-scarlet; lower petal pale lemon, Purple Glory. Extra-large, ruffled flowers of deepest velvety maroon with almost black Mrs. Frank Pendleton. An attractive variety with very large wide-open flowers of salmonCOLLECTION: One each of the above 9 named sorts, 65 cts., postpaid

Empress of India. The darkest and richest Gladiolus in our collection. Flowers large and

Delicate salmon-pink, lighter toward the center; well-shaped flowers on long stems. 7 cts. each, 75 ets. per doz.

Mrs. Francis King. An attractive variety, with light scarlet, wide-open flowers of imevery collection. $7 \mathrm{cts}$. each, 75 cts. per doz.

Panama. A seedling of the famous Gladiolus, America, and sure to become just as popular. Peace. The beautiful white flowers of this new introduction have pale lilac featherings on the 7 cts. each, 75 cts. per doz.

Niagara. Immense flowers, 4 inches in diameter, of rich cream shading to canary-yellow; throats tinged with carmine. 7 cts, each, $75 \mathrm{cts}$. per doz.

COLLECTION: One each of the above 6 named sorts, 35 cts., postpaid

\section{Mixtures of Gladioli}

Brunjes' Giant Mixed Every shade and color is included in this mixture, while the t. per doz., $\$ 4$ per 100, $\$ 35$ per 1,000 . flowers are
$\$ 35$ per 1,000

(a) A superb mixture comprising every shade known in Gladioli, 50 cts. per doz., $\$ 3.50$ per $100, \$ 30$ per 1,000 .

uccess Mixture. Contains a wide range of colors and is the best mixture offered considering doz., $\$ 3$ per 100 , $\$ 25$ per 1,000 .

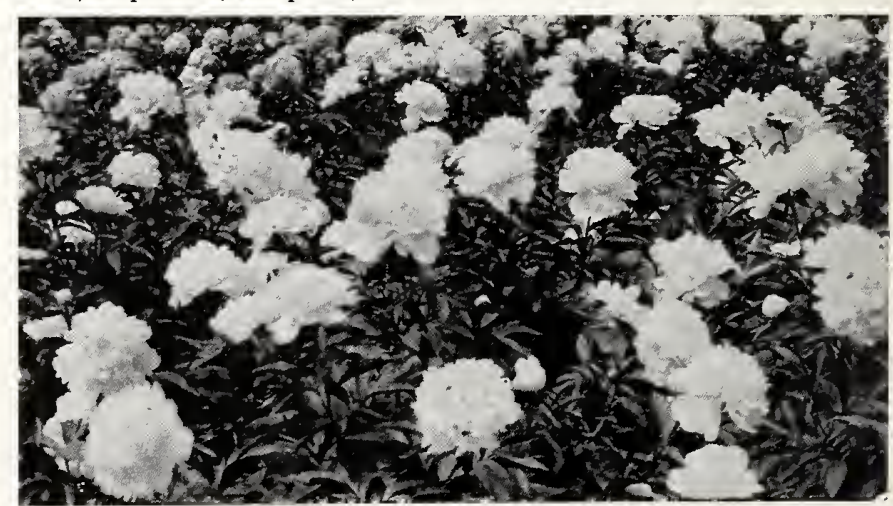

Peonies 
M. H. BRUNJES \& SONS

\section{Coldwell's Lawn Mowers}

Imperial Roller Bearing. Highly recommended Each as one of the very best high-wheel, roller-bearing Nowers. It cuts evenly, runs smoothly, and leaves the lawn in fine condition after cutting.

16-inch, five lylades. ...................... $\$ 1600$

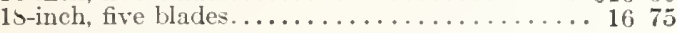

Colonial Lawn Mower. A low- $\pi$ heel, ball-bearing machine, especially recommended for small lawns.

12-inch, four blades

14-inch, four blades.

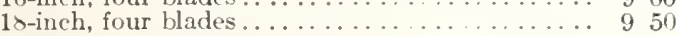

Hollywood Lawn Mower. A light-werght, lowwheel, four blade, ball-bearing Mower. Built low for rlose, fine work. Excellent for trimming. 12-inch, four blades..

14-inch, four blades

16-inch, four blades.

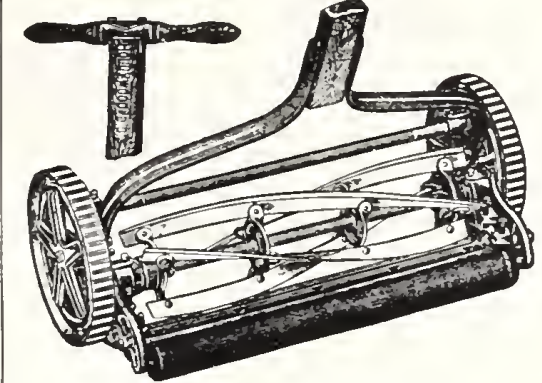

Hollywood Lawn Mower

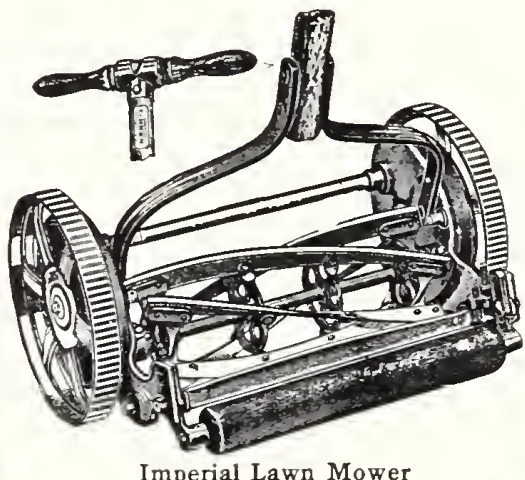

Imperial Lawn Mower

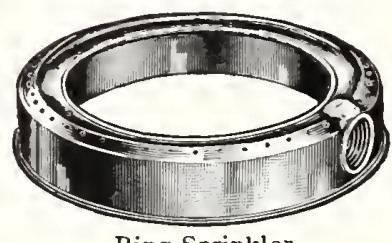

Ring Sprinkler

The Dunham Water-Weight

\section{Roller}

The drum is made of heary steel plates carefully Each welded togetlier to form a solid one-piece container for the water. The edgings of the drum are nicely rounded and will not cut or mar the lawn or tenniscourt. It is strong, durable, and casy rolling. Weight, empty; 80 pounds; filled with water, 310 pounds................................ 1550

\section{Lawn Sprinklers}

Anaconda. This Sprinkler is adapted for generai use and is very popular. Three arms; height 10 in. California. One of the most popular sprinklers, the arms of which are arranged to cover a large area. . .

Ring. Made entirely of sheet brass of an unusually heavy gauge. Throws a finely divided, welldistributed coarse spray.................

Preston. An ideal sprinkler for a small garden. With the exception of the sled it is all brass, and stands about 6 inches high.

Peck's Lawn Sprinkler. S-arm, nickel plated. A fountain attachment is included with Pcck's Lawn

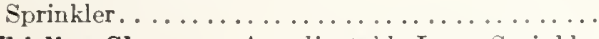

Whirling Showers. An adjustable Lawn Sprinkler of the revolving type; nozzles are adjustable for both volume of spray and distance. The arms can also be made stationary............... 225

All items listed above sent by express or freight at purchaser's expense

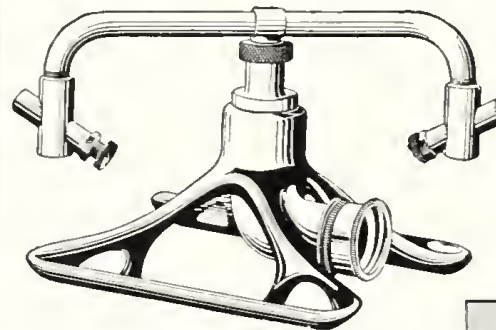

Whirling Showers Sprinkler

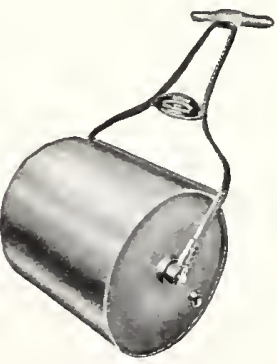

Dunham Roller

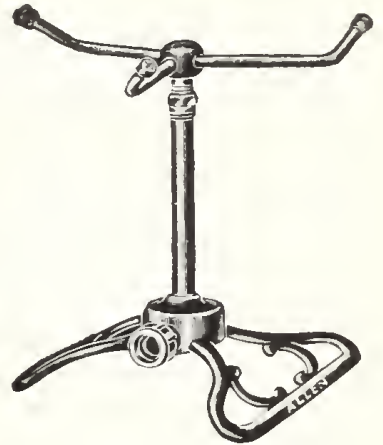

Anaconda Sprinkler

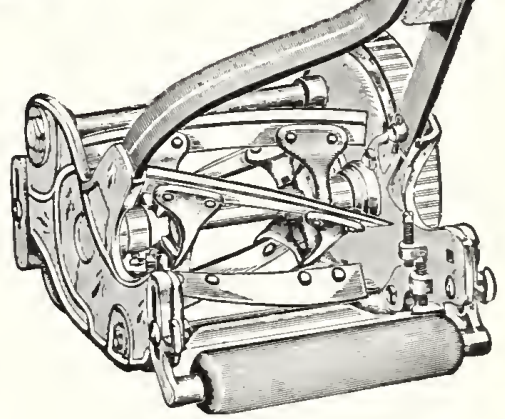

Lawn Trimmer

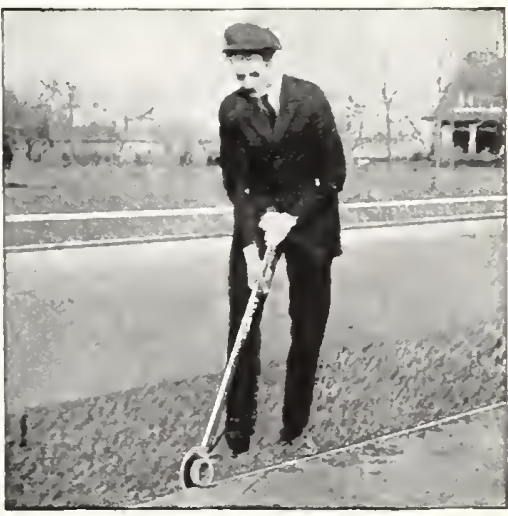

Planet Jr. Edger No. 2 


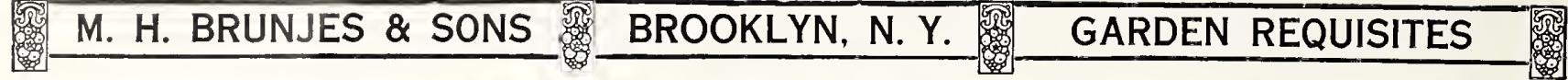

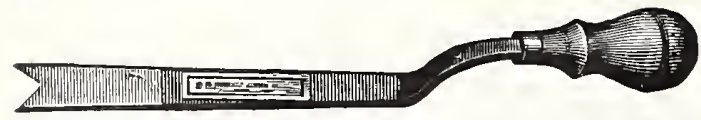

Asparagus Knife

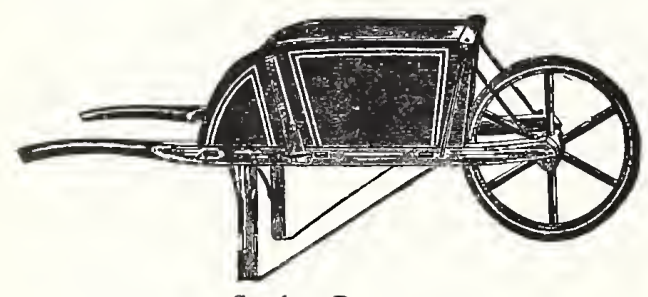

Garden Barrow

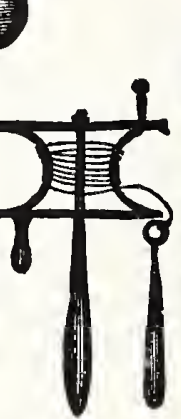

Garden Reel

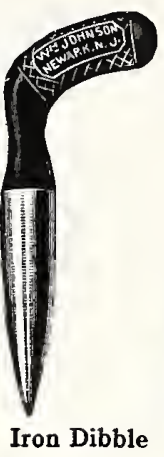

Iron Dibble
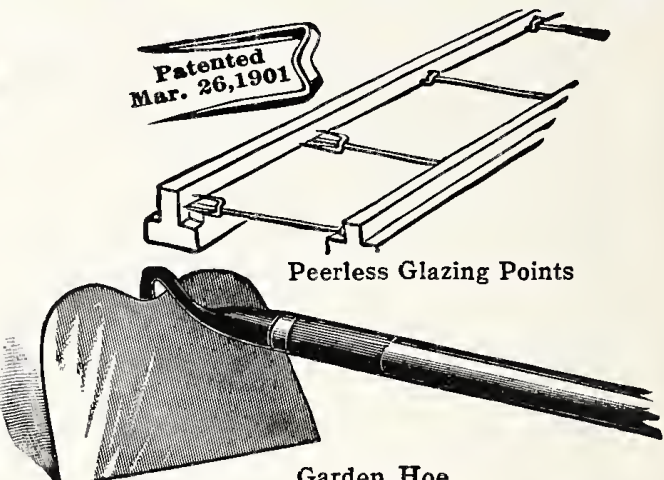

Garden Hoe

\section{Miscellaneous Garden Requisites}

ASPARAGUS KNIFE, American.

\section{GARDEN BARROWS}

Our Barrows are strong and well made, light but durable, and nicely finished. We carry six sizes in stock.

No. 2. Boy's, holding 2 cubic fcet.

No. 3. Garden, holding 3 cubic feet

No. 4. Medium, holding 4 cubic feet.

No. 4. Hothouse, for greenhouse use

No. 5. Regular, holding 5 cubic feet.

No. 6. Large, holding $6 \frac{1}{2}$ cubic feet.

DIBBLES, All-Iron or Wooden Handle. Medium or large..

DIGGEF, Post Hole. The blades are 9 inches long and the

handles 5 feet long.

\section{FORKS}

Manure, $\mathrm{D}$ handle, 4 tines, light.....

D handle, 4 tines, regular.

$\mathrm{D}$ handle, 5 tines, regular.

D handle, 6 tines, light.

Digging, or Spading. 4 tines, boy's.

4 tines, regular.

4 tines, heavy

5 tines.

Hay. Long handle; 2 tines

3 tines.

Stable. Long handle; 4 tines, strapped...

FRUIT PICKER, Wire.

GARDEN REELS

GARDEN LINE. Best braided.......per $100 \mathrm{ft} ., \$ 175$.

GARDEN SETS, For Children (hoe, rake and shovel) $20 \mathrm{c}$. and

For Ladies, well inade.

GLAZING POINTS, Peerless (Improved Van Reyper).

No. 2. For medium double-thick glass. Per box, 1,000, 75c

by mail, 90c.

No. 21/2. For large double-thick glass. Per box, 1,000, $75 \mathrm{cts}$. by mail, $90 \mathrm{c} .$. .

GRAFTING WAX. Per pkg., 20 cts., 35 cts., and 60 cts. ...

GRASS EDGING KNIFE. With handle.

GRASS HOOKS, or SICKLES, FAVORITE.

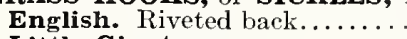

Little Giant .... .

GRINDSTONES, "Cycle"' Steel Frame. The stones are 19 to 22 inches in diameter, 2 to $2 \frac{1}{2}$ inches thick, and weigh

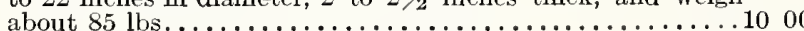

\section{HOES}

Garden, or Field. From 3 -inch to 8 -inch............. 110

Ladies'. 5-inch.

Riveted. $6 \frac{1}{2}$-inch.

Each

650

700

700

800
850

65

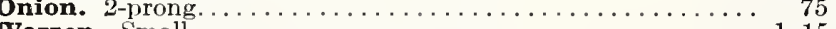

Warren. Small......................... 115

Medium.

Large.

$\begin{array}{ll}1 & 15 \\ 1 & 20\end{array}$

$\begin{array}{ll}1 & 20 \\ 1 & 25\end{array}$

190
9

225

$\begin{array}{ll}2 & 25\end{array}$

$\begin{array}{ll}1 & 00 \\ 1 & 85\end{array}$

225

$\begin{array}{ll}2 & 35 \\ 1 & 35\end{array}$

160

70

135

Midget. Similar to the above, but with short handle.........

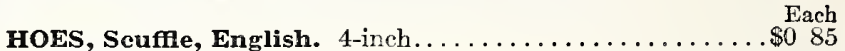

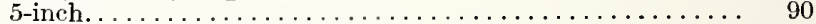

6 -inch............................... 95

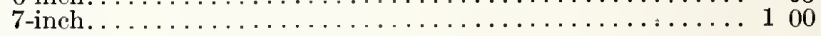

HOE and RAKE COMBINED. 4 tine .............. 110

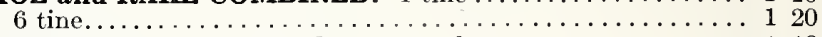

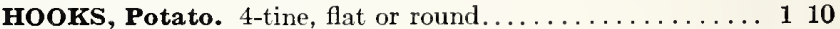

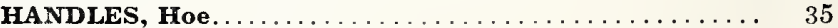

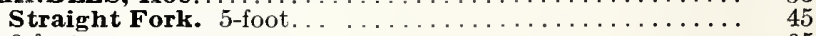

6 -foot............................ 65

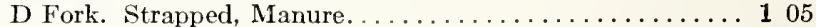

D Fork. Plain........................ 70

\section{RUBBER HOSE}

We can highly reeommend the following grades which we have been handling for a good many years. All grades supplied in 25 and 50 -foot lengths and prices include couplings.

Electric. The Electric Hose has corrugated surface, is very light and will not kink. It is largely used by market-Perft. gardeners and florists. $\frac{3}{4}$-inch. 2 -ply................

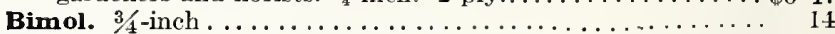
HOSE COUPLINGS. Brass. $\frac{3}{4}$-inch....... per pair, 30c.. E Each HOSE ENDS. For attaching to smooth faucets; $\frac{3}{4}$-inch... . . . $\$ 040$ HOSE CLAMP, Bull Dog. Used to fasten around couplings. Easily applied ....................... Doz. $60 \mathrm{c} .$.

HOSE BANDS. Made of brass wire. . Doz. 15c., gross, $\$ 1.35$. .

HOSE MENDERS, Cooper's. The best on earth. Made of brass, $\frac{3}{4}$-inch.................... Doz. $\$ 1.25$. .

HOSE WASHERS, Rubber. $\frac{3}{4}$-inch . . . . . . Doz. 8c., lb. $\$ 1$. HOSE NOZZLES-

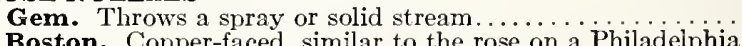
Watering Can Any of the above Nozzles by mail, 10 ets. extra.

HOSE REELS, Victor ............. 75

Iron. Small; carries 100 feet ${ }^{3}$-inch hose............ 500

Iron. Large; carries 150 feet $\frac{3}{4}$-inch hose............. 5

JACKS, Wagon, Samson. No. $1 \ldots \ldots \ldots \ldots \ldots \ldots \ldots \ldots \ldots$

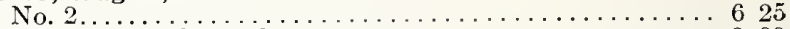

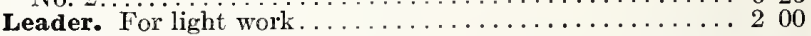

LABELS, Wooden, Pot and Garden- $100 \quad 1,000$ 4 -inch, plain....................... $\$ 025 \$ \$ 160$

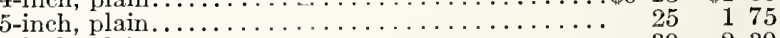

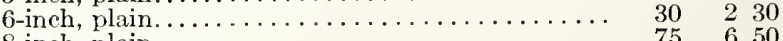

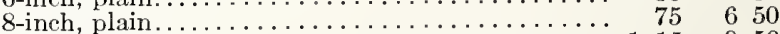

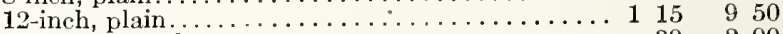
4-inch, painted.................... $30 \quad 200$ 5 -inch, painted..................... $30 \quad 210$ 6 -inch, painted...................... $35 \quad 250$ 8 -inch, painted............................. $100 \quad 850$

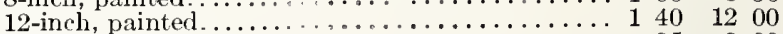

Copper-Wired. Painted................ $35 \quad 300$

MATTOCKs. With handle.................. $\$ 165$ MOLE TRAP, Reddick. Considered to be the best Mole Trap on the market today. It is simple and easy to set... 150 OYSTER SHELLS. Crushed......... bag 100 lbs., $\$ 1.90 \ldots$ 


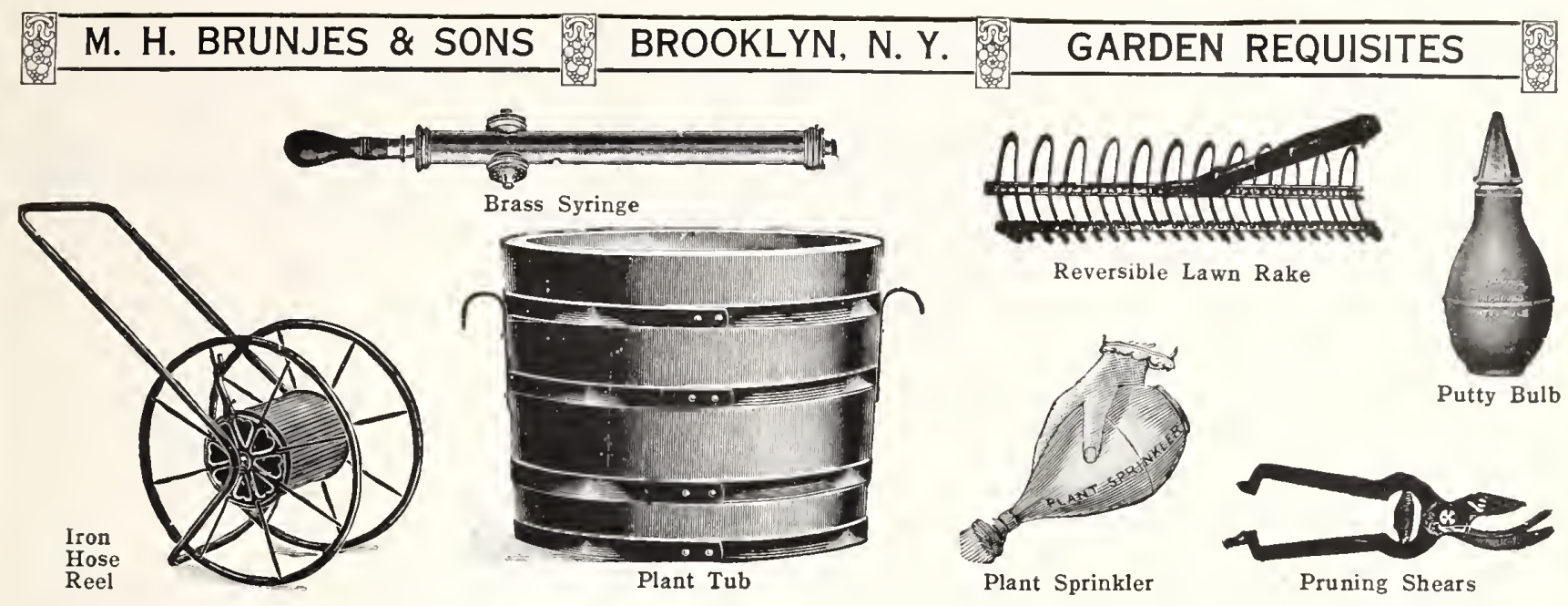

\section{Plant 'Tubs}

Our plant tubs are made of cedar with extra-heavy staves, and hoops. They have drop handles, are very strong and durable, and the best-made tub on the market. Painted green.

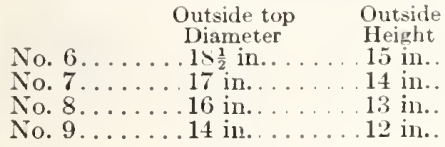

Each

$\$ 365$

$3 \quad 25$

225

PLANT SPRINKLER, Rubber. Large

Rubber. Medium.

PICKS, Railroad. With handle

Contractor's. With liandle.

PUTTY BULB, Rubber. Excellent for glazing.

\section{WOOD ANI STEEL RAKES}

Steel Garden. We can supply either straight or curved teeth at prices listed. 10 teeth

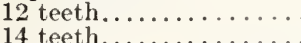

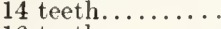

16 teeth.

Steel Road. 14 teeth, straight; extra heavy

Reversible Lawn. Excellent for removing grass, leaves, etc. from the lawn.

Wood, Lawn. 22 teeth.

Hay. 3-bow, 12 teeth

Bamboo, Lawn. 18-inch.

RAFFIA, Natural. For tying plants and vegetables. lb. $45 c_{\text {c., }} 10 \mathrm{lbs} . \$ 4$.

SAwS, Pruning. Double edge; 16 -inch. .

\section{PRUNING, HEDGE AND GARDEN SHEARS}

Pruning, Hand. Coil, brass spring. California Pattern.

California Pattern. Full nickel-plated with ratchet nut

Pruning, Hand. For cutting thick branches. Handles 20 inches long...

With noteh

Pruner, Tree. 10 feet

12 feet............

Hedge, American. 8-inch cut $\$ 2.25$, 9-inch cut, with notch. Ladies'.

Grass, Trowel Shank

Better quality.

Finest and best.

SCYTHES, English Lawn. 30-inch, best steel.... 225 Weed, or Bush. Blades are short and strong. Used for heavy work.

SCYTHE HANDLE, or SNATH. Suitable for any of the above Scythes......................... 150

SCYTHE STONES. Round.......

Pike's Flat.

Emery (Lightning)

Emery Rifle...

SCRAPER, Steel Snow. Extra-heavy, long handle...........
SHOVELS, SPA DES ANI SGOOHS

Shovels, Tissot No. 2. Round point, D handle

Maynard Socket. Round point, D handle.

Tissot No. 2. Square point, D handle.

Tissot No. 4. Square point, D handle.

Tissot No. 5. Square point, D handle.

Maynard Socket. Square point, D handle.

Tissot No. 2. Square point, long handle.

Tissot No. 2. Round point, long handle.

Steel Snow, Tissot. Long handle.

Steel Snow. Long handle...

Wood Snow.

185

Maynard. $D$ handle; socket...................... 175

Tissot. D handle; good cuality . . . . . . . . . . 135

Tissot. Long handle.

Scoops, Sanderson's. Best steel; D handle. No. 2....... 165

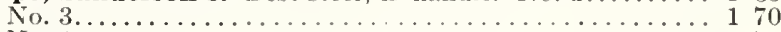

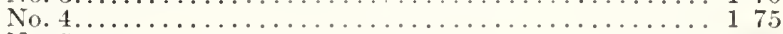

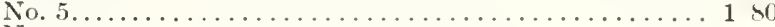

Root, or Potato. Galvanized steel wire.............. 240

\section{S'TAKLS OR DAHLIA POLES}

A very good support for Dahlias, Roses, etc. They are round, very strong, painted green and taper to a point. Will last several years. Each Doz. Each Doz. 3-foot .......\$0 10 \$1 $15 \mid 5$-foot...........\$0 $16 \quad \$ 190$ 4 -foot ..... $13 \quad 150 \quad 6$-foot.......... $19 \quad 225$

Stakes, Cane, Bamboo. 6 -ft. $1,000, \$ 17 \ldots \ldots \ldots . \$ 0 \begin{array}{lll}\text { Doz. } & 100 \\ \$ 2 & 25\end{array}$

Dowels. A very neat support for small plants.

Not painted; $\frac{3}{8}$ inch in diameter and 3 feet long.... $30 \quad 3025$ Not painted; $\frac{1}{2}$ inch in diameter and 3 feet long.... $40 \quad 300$

\section{SYRINGES}

Heavy brass for greenhouse and garden

No. A. Length of barrel, 12 inches; diameter, 1 inch; one Each spray rose and olle jet.

No. G. Length of barrel, 16 inches; diameter, $1 \frac{1}{2}$ inches; one spray rose and one jet, side attachment, and angle joint for spraving under foliage

No. 5. Length of barrel, 18 inches; diameter, $1 \frac{1}{2}$ inches; with patent valves, two spray roses (one fine and one coarse), one jet and side attachments.

\section{TROW ELS}

Steel Garden. 6-inch.

English Pattern. 6-inch.

$\$ 0 \quad 15$

Solid Steel. 6-inch

Forged Steel. 6-inch.

Ladies' Flower, 6-inch, narrow

Transplanting. 6-inch, narrow.

Transplanting Hoe. Used in setting out Cabbage, Tomato and other plants; 7 -inch.

Bulb. Large, broad blade; for planting out pot plants and bulbs. $6 \times 4 \frac{1}{2}$ inches.

TWINE, Jute. For tying plants and vegetables. 2- and 3-ply on balls.................................. 


\section{H. BRUNJES \& SONS Brig}

\begin{tabular}{|c|c|c|c|c|c|}
\hline Standard & \multicolumn{2}{|c|}{ Hlower } & I ots. & \multicolumn{2}{|c|}{ Saucers, Etc. } \\
\hline $\begin{array}{c}\text { Size } \\
2 \frac{1}{2} \text {-inch }\end{array}$ & $\begin{array}{r}\text { Each } \\
.6003\end{array}$ & $\begin{array}{l}\text { Doz. } \\
\$ 035\end{array}$ & $\begin{array}{l}\text { Size } \\
\text { o-inch }\end{array}$ & $\begin{array}{c}\text { Each } \\
5028\end{array}$ & $\begin{array}{r}\text { Doz. } \\
\$ 3225\end{array}$ \\
\hline 4 -inch. & . 05 & & 9-inch. & . 40 & \\
\hline 5 -inc & 08 & 90 & 10-inch. & 50 & \\
\hline & 15 & 170 & 11-inch. & 70 & \\
\hline 7 -inch & 20 & 225 & 12-inch. & 90 & 1050 \\
\hline
\end{tabular}

Flower Pot Saucers.

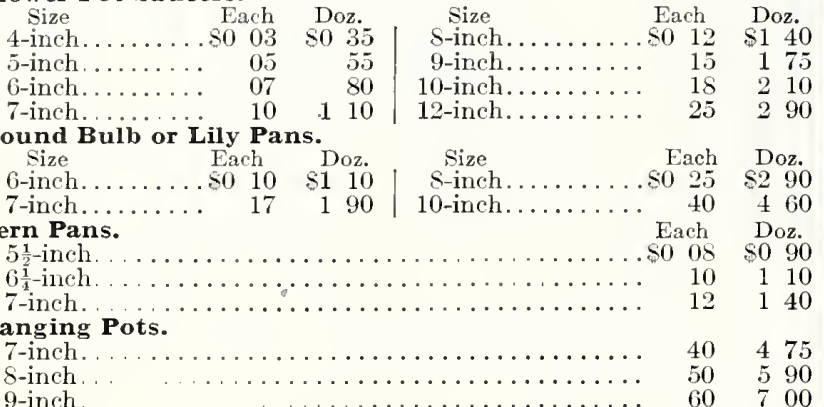

\section{Sprayers and Spray Pumps}

Brunjes' All-Brass Spray Pump. This is one of the strongest Each and most durable bucket pumps for the garclen or greenhouse. It has solid brass working parts, a foot rest of malleable iron, 3 feet of hosc and combination nozzle which throws a fine or coarse spray and solid stream. It is double acting

Perfect Success. An excellent bucket pump for all spraying purposes. It is easily operated, may be attached to the pail by means of a patent clamp and is fitted with 3 feet of hose and Bordeaux Nozzlc

Auto-Spray. A simple but well-constructed automatic sprayer, used by innumerable florists, nurserymen and gardeners throughout the country. The auto-pop is a device for controlling the spray. Full directions given with each pump.

Galvanized Iron Tank, with auto-pop............6 00 Brass Tank, with auto-pop ................. 900

Brass Extension Pipe. 2 feet long. ........... 50

Brass Strainer............................. 120

Faultless Sprayer. A handy and useful article for small gardens. Holds about one quart. All brass. . . .

Galvanized Can, tin tube.

All Tin..... .

\section{DRY POWDER DUSTERS}

Champion Dry Powder Gun, Leggett's. Each machine is furnished with 4 tubes, 6 nozzles, 2 straps and oil can: will dust two rows of potatoes at a time. Weighs about 6 lbs, 1400

Little Giant Powder Gun, Leggett's. Same as the above, only smaller.

Woodason's. Small single-cone bellows.

Tin Duster. Used largely for slug shot; holds 2 qts......... 60

Galvanized.

\section{Watering Cans}

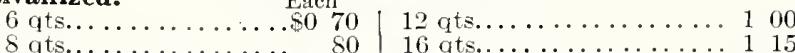

10 ats.................. 90

Philadelphia Pattern. Extra heavy, with long spout; each equipped with two copper-faced roses. 6 qts............. 375

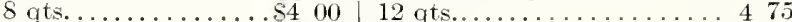

10 qts............4 45 , 16 qts............. 525

WEEDERS, Eureka. 3 prongs; steel. .

Hazeltine.

Excelsior.

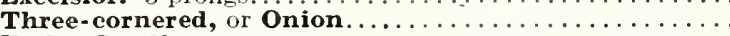

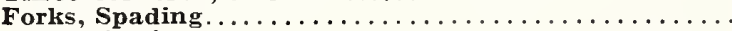

Forks. Steel.............................

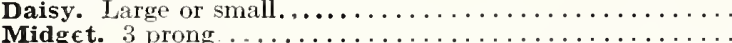

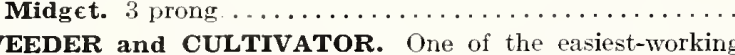
and most useful hand garden tools on the market. It has 5 prongs and a 4 -foot handle.

All items listed above sent by express or freight at the purchaser's expense
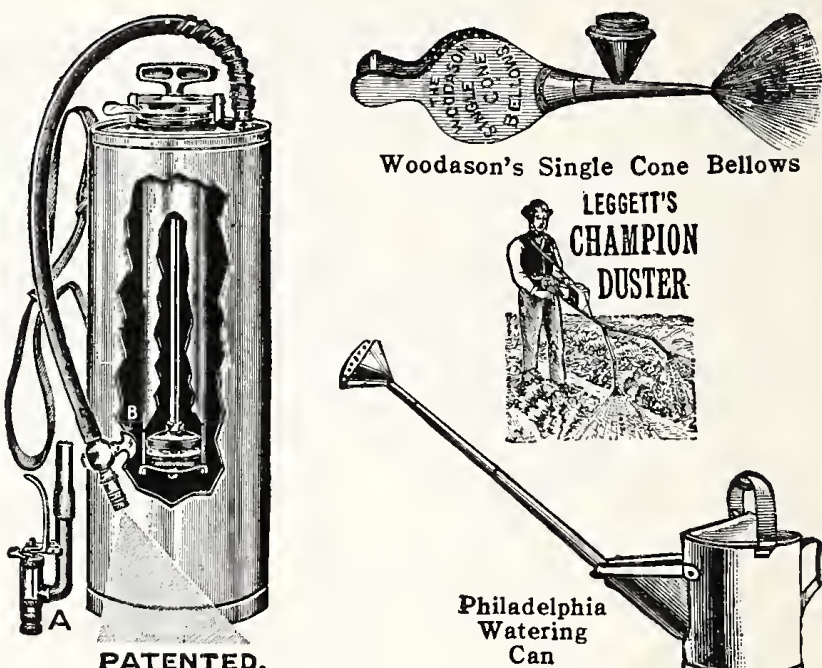

Woodason's Single Cone Bellows

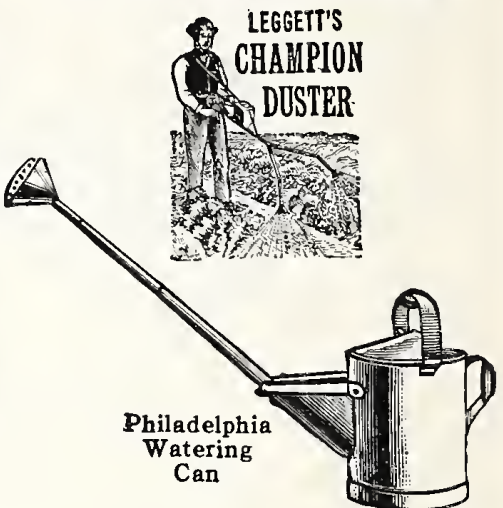

Auto-Spray
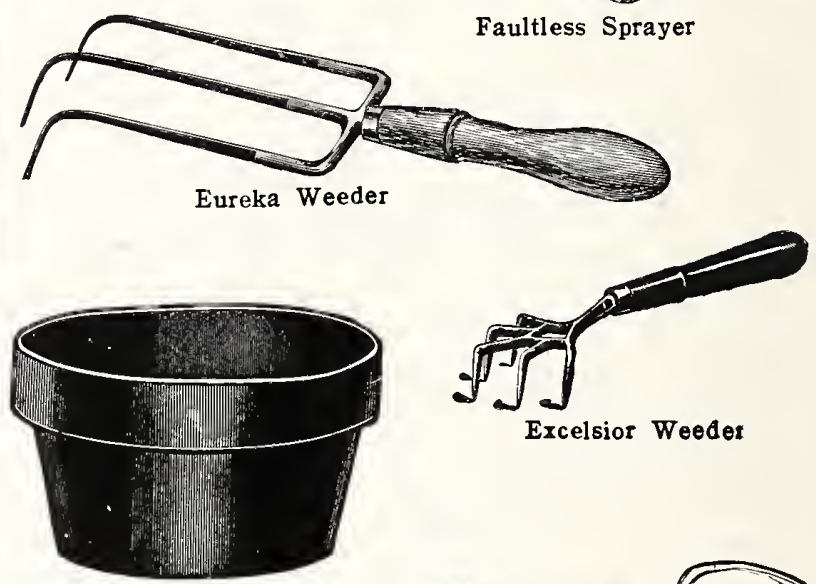

Excelsior Weeder

Bulb Pan
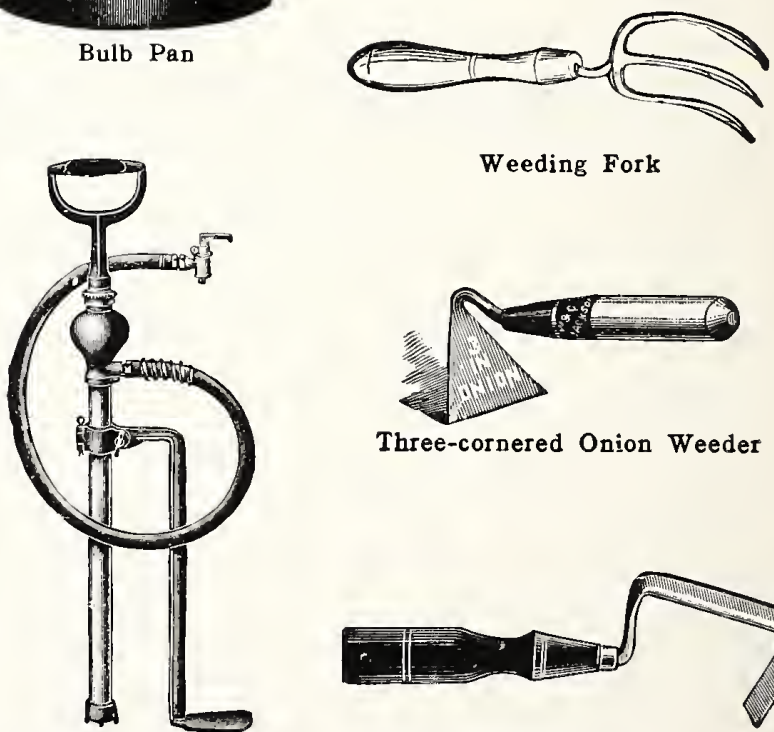

Weeding Fork

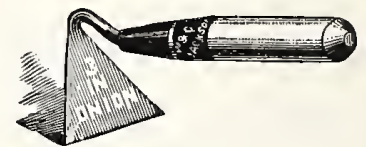

Three-cornered Onion Weeder

Brunjes' Spray Pump 

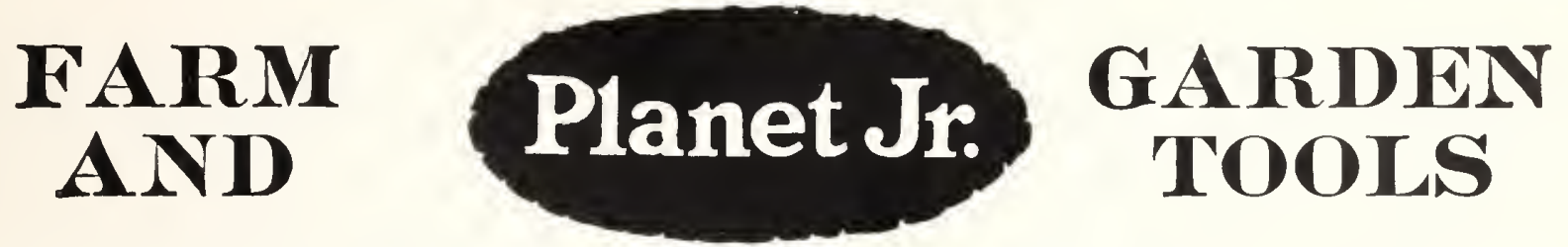

While there are thousands of users of these well-known labor-saving tools, still there are many gardeners who lave yet to know the pleasure and the profit from working with them. They do a great variety of work for the home, the market gardener and the general farmer. Planet Jr. tools are saving time and labor in the sowing and cultivating of many crops. They are strongly made, easily operated, all adjustments made quickly, and will give many years of service.

\section{Seed Drills}

No. 25 Hill and Drill Seeder, Double and Single Wheel Hoe combined. Sows all vegetable seeds in drills or drops in hills $4,6,8,12$, or 24 inches apart, at the proper depth and thickness and economically. Inlex accurate, and sows uniformly. Cultivating attachments consist of a pair of plows, 4 steel cultivator teeth, a pair 6 -inch

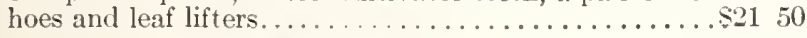

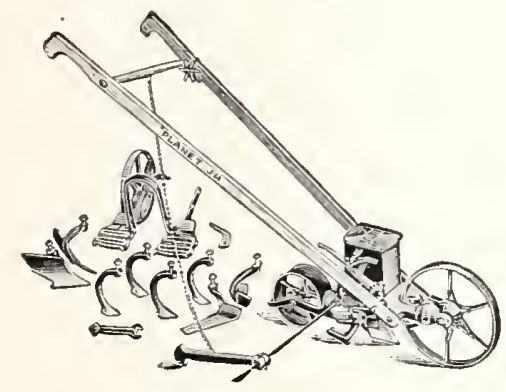

No. 4 Hill and Drill Seeder and Single Wheel Hoe. Same as the No. 25 but used as a single $W^{\prime}$ heel Hoe only. Sows all vegetable seeds in hill or drill as above men-

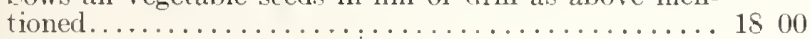

No. 3 Hill and Drill Seeder. Sows in the hill or drill. Holds 3 quarts of seed. The market gardener's favorite. . 1750

No. 5 Hill and Drill Seeder. Same as the No. 3 but holds 5 quarts of seed....................... 2000

\section{Wheel Hoes}

No. 11 Double and Single Wheel Hoe Combined. The most complete Double and Single Wheel Hoe offererl today. Equipment consists of a pair of plows, a pair each of 6 -inch and $4^{1 / 2}$-inch hoes, 4 cultivator teeth, 2 threetooth and 2 five-tooth rakes, a pair of leaf lifters. Tsed as a Double Wheel Hoe it will stradlle the row until the plants are 20 inches high. Then can be used as a single Wheel Hoe between rows.

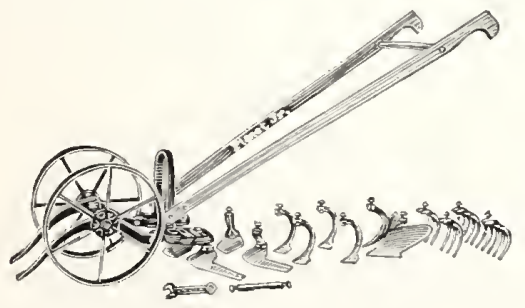

No. 12. Same, less the rakes and $4 \frac{1}{2}$-inch hoes.

No. 13. Same, with one pair 6 -inch hoes only

800
No. 16 Single Wheel Hoe. Planet Jr. Single Wheel Hoes do practically the same variety of work as the double, but are lighter. The No. 16 equipment inclurles a pair of 6 -ineh hoes, large garden plow, 3 steel cultivator teeth, and a leaf-lifter. It is a great favorite among home garleners.

No. 17. Sime, less the rakes.

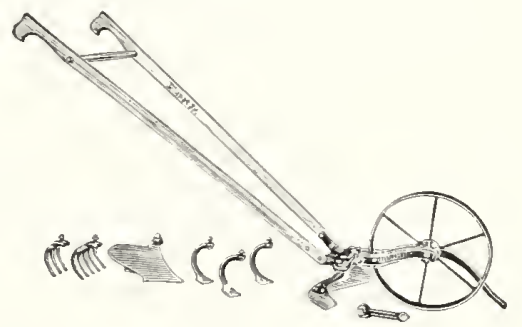

No. 171/2. Same as No. 17, less the plow.......... 6 75

No. 18. With pair of 6 -inch hoes only......... 5 is

No. 19. Farmers' Wheel Hoe, Cultivator, and Plow .. 600

Fire Fly Plow..................... 425

\section{Ḱopper's Velvet Lawn Sulphate of Ammonia Fertilizer}

Feerls the grass and starves the weeds. Acts fast and gives satisfaction. Apply 1 pound to 250 square feet.

26-oz. box ........... 8025

5-lb conister . 60

10-lb. bag............. 115

25 -lb. bad . . . . . . . . 225

50 -lb. bag. . . . . . . . . 375

100 -lb. bag............ 600
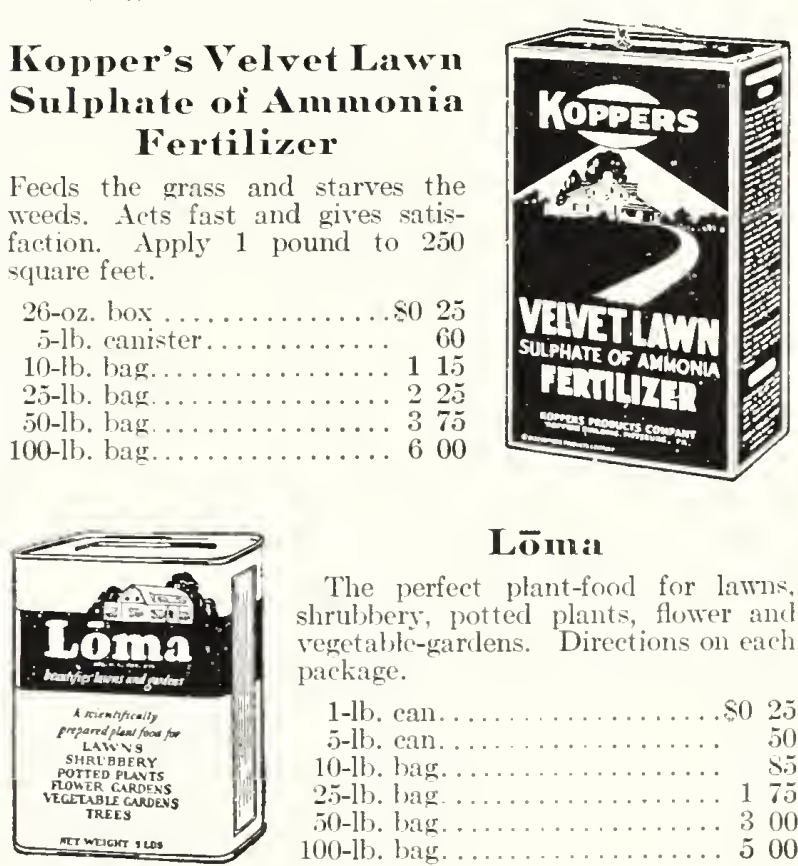

\section{Lōma}

The perfect plant-food for lamns. shrubbery, potted plants, flower and vegetable-gardens. Directions on each package.

1-lb. can. .

5-lb. can.

10-lb. bag.

25-lb. hag.

$50-16.62$. b.

100-lb. bag.
8025

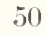

85

175

300

500 


\section{H. BRUNJES \& SONS 留 BRO B Index}

VEGETABLE SEEUS

Artichoke.

Asparagus. .

Beans

Beets

Beet, Spinach

Beet, Sugar.

Borage

Borecole

Broceoli

Brussels Sprouts

Cabbage

Cardoon.

Carrot..

Cauliflower

Celeriac...

Celery.

Celery, Turnip-rooted

Chard, Swiss

Chervil.

Chicory

Chives.

Citron

Corn Salar.

Corn, Sweet

Cress

Cress, Water.

Cucumber.

Dandelion.

Dill

Eggplant.

Endive.

Fennel.

Garlic.

Gumbo

Herbs, Sweet, Pot and Medici-

nal

Kohlrabi.

Leek.

Lettuce

Mangel-Wurzel

Mushroom Spawn.

Muskmelon.

Mustard . . .

Nasturtium

Okra...

Onions.......

Parsley

Parsnip

Peas.

Pepper.

Pumpkin

Radish . .

Rhubarb.

Romaine.

Rutabaga .

Salsify.

Sorrel.

Spinach

Squash

Swiss Chard

Tobacco.

Tomatoes

Turnip

Vegetable Plants and Roots. . .28

Watermelons.............17

Bird Seed

\section{FARM SEEDS}

Buckwheat..............28

Clover..................28

Corn, Field.............28

Grass Seed .............

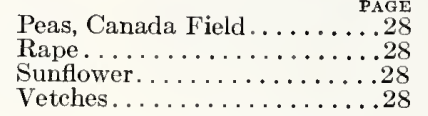

\section{FLOWER SEEDS}

Abronia

Abutilon.

Achillea .

Aconitum .

Acroclinium

Adonis.

Ageratum .

Agrostemma

Aloysia

Alyssum.

Amaranthus

Anemone . .

Antirrhinum

Apple, Balsam .

Aquilegia

Arabis

Arctotis.

Asparagus.

Asters

Baby's Breath

Balloon Vine.

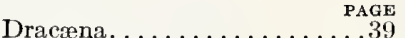

Dusty Millers....................

Echinocystis............41

Eschscholtzia............40

Esehscholtzia, Bush........42

Euphorbia...............41

Feverfew.............43

Fire Plant...............

Flax.................43

Forget-me-not..........44

Four-o'Clock. . . . ........44

Foxglove............... 39

Fringe, Mountain . . . . . . . 30

Gaillardia . . . . . . . .

Geranium..............41

Globe Amaranth . ..........41

Godetia................41

Gomphrena.............41

Gourds. . . . . . . . . . . . 41

Grasses, Ornamental........41

Gypsophila.............41

Helianthus.............41

Helichrysum............41

Heliotrope..............41

Hesperis..............52

Hollyhock..............

Hop, Japanese . . . . . . . . . 42

Horn of Plenty . . . . . . . . . 39

Humulus...............4

Hunnemannia. . . . . . . . 42

Iberis................

Ice Plant...............42

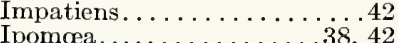

Ipomoea............. . 38,42

Jacobrea ................ 42

Joseph's Coat.....................

Kochia...................

Lady's Slipper . . . . . . . . . . 34

Lantana................42

Lantern Plant, Chinese.......47

Larkspur............. 39, 43

Lathyrus...............46

Linaria . . . . . . . . . . . .43

Linum......................

Lobelia...............443

Lophospermum...........43

Love-in-a-Mist. . . . . . . . . . 45

Love-Lies-Bleeding............. 31

Lupinus...............44

Lychnis...............43

Malope $\ldots \ldots \ldots \ldots \ldots \ldots \ldots \ldots, 434$

Marvel of Peru . . .........44

Matricaria . . .............. 43

Matthiola...............43

Mesembryan themum . . . . . . 42

Mignonette.............44

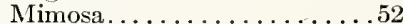

Mimulus...............

Momordica.................44

Monkey Flower. . . . . . . . . .444

Moonflower.............42

Morning-Glory ............... 37

Mourning Bride..........51

Musk Plant..............44

Myosotis..............444

Nasturtiums............

Nemesia ..............44

Nemophila............44

Nicotiana............45

Nigella.................

Enothera.............45

Oxalis................45

Pansies...................

Pansies, Tufted ...............47

Peach Bells..............35

Pear, Balsam...........44

Peas, Perennial . . . . . . . . . 46

Pentstemon . . . . . . . . . . 47

Periwinkle............52
PAGE

48

Physalis................

Pinks...............40

Platycodon............. 53

Poppies...............48

Poppy, California..........40

Portulaca .............50

Primrose, Chinese . . . . . . . . .49

Primrose, Evening.......... 45

Primula............... 49

Pyrethrum.............5 50

Red-hot Poker Plant. . . . . . .52

Reseda................44

Rhodanthe ............. 50

Ricinus.............50

Rose of Heaven. . . . . . . . . . . 30

Rudbeckia...............50

Salpiglossis. . . . . . . . . 51

Salvia .............. 51

Sanvitalia..............51

Scabiosa . . . . . . . . . .

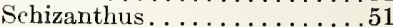

Sedum..............51

Sensitive Plant............52

Smilax..................... 52

Snapdragon ................... 31

Snow-on-the-Mountain . ......41

Solanum ............... 52

Spider Plant. .................. 37

Stocks............ 43, 52

Stock, Virginian......... 52

Stokesia..............52

Stonecrop.....................

Straw Flower..........41

Sunflower..............41

Sweet Peas. . . . . . . . . . . .46

Sweet Rocket................ 52

Sweet Sultans . .........36, 52

Sweet William............52

Thunbergia.................. 52

Torenia............. 52

Tritoma................ 52

Tropæolum..........45, 52

Trumpet Flower . . . . . . . 39

Verbena................. 53

Verbena, Lemon . . . . . . . . .53

Verbena, Sand .................

Vinca............. 52

Viola..............

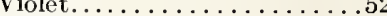

Wahlenbergia...........53

Wallflower................. 53

Whitlavia............53

Wild Flower Garden Mixture. . 53

Woolflower, Chinese.........37

Xeranthemum .............. 53

Youth and Old Age........54

Zinnia...............54

\section{BULBS, ROOTS AND}

Amaryllis . PLA........... 55

Bleeding Heart . . . . . . . . . 55

Caladium. . . . . . . . . . 55

Cannas.............................

Cinnamon Vine.........55

Clematis..............55

Dahlias ..............57

Dielytra ....................

Elephant's Ear............55

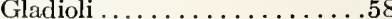

Hyacinthus................

Lilies, Japanese . . . . . . . . 56

Madeira Vine............55

Oxalis . . . . . . . . . . . . . 56

Peonies.................... 58

Tuberose.................

Implements, Miscellaneous 59-63

Insecticides .......... 3 , $3 \mathrm{~d}$ cov.

Fertilizers. . . . . 22, 26, 63, 3d cov. 


\section{INSECTICIDES}

Liquids and poisonous powders are not mailable and can be sent by express only, at purchaser's expense

Arsenate of Lead (Powdered). Has all the advantiges of far, and is easier to handle. Dilute 1 pound to 50 grillons of water. Lb. 40 ets., 5 lbs. $\$ 1.75,10$ lbs. $\$ 3.25,25$ lbs. $\$ 5$.

Black Leaf 40. A powerful insecticide and when used as a spray, protects plants, shrubs, trees, and all foliage from the attacks of insects. One ounce to 6 gallons of water is the proper spraying solution. Highly recommended for the rose bug, greenfly, plant lice, ete. 1-oz. bottle $35 \mathrm{cts.,} 5$-oz. bottle $\$ 1$.

Bordeaux Mixture (Powdered). For all fungous diseases such as rust, potato blight, mildew and various 5 lbs. $\$ 1.50,10 \mathrm{lbs}$. $\$ 2.75$.

Bug Death. A highly effective, non-poisonous insecticide. Can Death. be used safely on veretables, fruit, or flowers. Lb. 25 ets., 5 lbs. 90 ets.

Fish-Oil Soap. A reliable insecticide for general use. It is easily applied to trees, plants and vines whether for

Fungtrogen. An effective and scientific preventative and remedy gtrogen. for mildew, black-spot, and many fungous rliseases of roses and other plants. $1 / 2 \mathrm{pt} .75 \mathrm{cts.}, \mathrm{pt}, 81.25$.

Hellebore. One of the best insecticides for the garden, especially Hellebore. for roses, currants and other small fruits. Apply with bellows or in water-one ounce of Hellebore to two gallons of water. 1, 1b. $20 \mathrm{cts}, 1 / 2 \mathrm{~b} .30 \mathrm{cts} ., \mathrm{lb} .50 \mathrm{cts}$.

Lime-Sulphur (Powdered). For dormant spraying of fruit or shade trees and bushes against San José and oyster shell scale. Also peach-leaf curl and brown-rot of peaches. Much easier to handle than the liquid and is just as effective. One pound makes 5 gallons. Lb. 35 cts., 5 llss, $\$ 1.25,10 \mathrm{lbs} . \$ 2$.

Nico-Fume Powder. For fumigating greenhouses. Lb. \$1,
Nico-Fume. A strong, free nicotine solution used effeetively for Nico-Fume. spraying all plants for phant-lice, thrip, red spider.

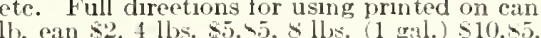

Nikoteen. A highly refined solution of free nicotine, especially recommended for greenhouse spravingr. One ourace to six gallons of water is the proper spraying solution. Oz. 3.5 ets., $1 / 2$ lb. $\$ 1.25$, lb. $\$ 2$.

Nicotine-Pyrox. A sure remedy for alt leaf-eating and surcling

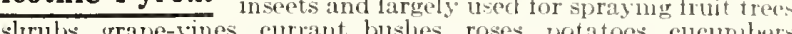
curant busles, roses, potatoos, cucumburs ete. A combined insecticide and fungicide which should be nixed with cold water. $10 \mathrm{oz} \% 50 \mathrm{cts}, 21,211 \mathrm{~s} .82$.

Paris Green. A poisonous powcker largely useck to kill potato aris Green. bugs, caterpillars, ete. Can be uned either thry or as a spray. For the potato bug use one tablemoonful to sixf(e+2)

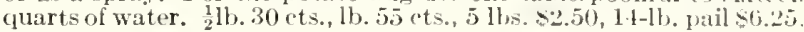

Scalecide. The best spray for San José scale and all other kint. Scalecide. of scale on every kind of tree or hush. Lse one galor early spring, while the folinge is off. Qt, 70 cts., gal. $\$ 1.60,5$ gals. $\$ 6,10$ gals. $\$ 10$.

Slug-Shot, Hammond's. A non-poisonotis insecticide used and currant worm, rose and want lice, ete, also for fice the cabbage Lb. 20 ets., 5 llss, 65 ets.

Tobacco Dust. A sure remedy for plants affected with lice, Dust. aphis, green fly, etc. Use freely. Lb. 10 ('ts. $5 \mathrm{lbs} .35 \mathrm{cts} ., 10 \mathrm{lbs} .60 \mathrm{cts}, 50 \mathrm{lbs} . \$ 2.25,100 \mathrm{lbs}$. $\$ 1$.

Weed Killer. For keeping walks, trives and tennis-courts free Wrom weeds, there is nothing better. Add fron 11) to 20 parts of water. (2t. 60) cts., gill. s1.50, is gals. sto.

\section{FERTILIZERS}

\section{BonexMeal}

One of the best fertilizers for the lawn, encouraging a luxuriant dark green growth, especially if applied before a rain. Equally good either for pot-plants or rose and carnation-culture. Lb. 1it cts., 5 lbs. 40 cts., 10 lbs. 70 cts., 20 llss. $\$ 1.25,501 \mathrm{lbs} . \$ 2.50,100 \mathrm{lbs} . \$ 4.25$, 500 lbs. $\$ 20$, ton $(2,000$ lbs. $) \$ 70$.

\section{Stim-U-Plant}

This wonderful fertilizer and plant-food is odorless-has no obnoxious, messy characteristics. To use, simply insert a tablet in soil near each plant; or dissolve in water at the rate of four tablets per gallon and use as liquid manure. 30 tablets 25 cts., 100 tablets 75 ets. 1,000 tablets $\$ 3.50$.

\section{Agricultural Lime}

This is an efficient agent to correct soil acidity. For vegetables, flowers, and grass use about 1 pound of agricultural lime to 20 square feet of soil. Sprinkle evenly over the ground and work it into the surface of the soil with a lrand rake. Can be applied any tine of the year without danger. 5 lbs. 30 cts., 10 lbs. $45 \mathrm{cts} .25 \mathrm{lbs} .80 \mathrm{cts}$. 50 lbs. $\$ 1.25,100$ lbs. $\$ 2$.

\section{Sheep Manure (Wizard}

When mixed with soil or used as a liquid fertilizer, it is very beneficial to all plant life, whether in the greenhouse or garden. Although not so quick in action as some fertilizers, it is more lasting and insures a continuous, steady growth. Lb. $15 \mathrm{cts}, 5$ lbs. 40 ets., 10 lbs. 70 c.ts. 25 lbs. $\$ 1.25,50$ lbs, $\$ 2.25$, bag (100 lbs.) $\$ 3.75$, ton $\$ 60$

\section{Agrico Fertilizer}

An excellent fertilizer for general use in the vegetable-garden. It will be found a good substitute for stable manure, and is not only cleaner but much easier to handle. If the soil is in fairly good conrition, 100 pounds will be sufficient for a plot $25 \times 100$ feet. Lb. 10 cts., 5 lbs. 30 cts., 10 lbs. 55 cts., 20 lbs. $\$ 1,50$ lbs. $\$ 2.25$, bag $(100$ (bs.) $83.75,500 \mathrm{lbs}, 817$, ton $(2,000 \mathrm{lbs}) 800$

\section{Peat Moss}

Excellent for keeping hark, clayey soils loose and eneourates real root derelopment; absorbs and holds moisture. Large bag (15 lls.) 75 cts., bale (about 150 lbs.) $\$ 4,5$ bales $\$ 17.50$.

\section{Driconure}

Espreially good for top-dressing lawns, rose-beds, and general rarden use 1 combination of 35 per cent peat noss and 65 per cent cow-minure; free from weeds. Bag of about $50 \mathrm{lbs}, 82.50$.

\section{Hyper Humus}

Hyper Humus is a natural organic substance similar to leaf-mold but in a more concentrated form, very black and odorless. Recommended for lawns, flowers, and vegetable-gardens, $5 \mathrm{lbs}, 25 \mathrm{cts.} 10$ lbs. 40 cts., 25 lbs. 80 cts., 50 lbs. $81.35,100$ lbs. $\$ 2.25,500$ lbs. $\$ 10$, $1 / 2$ ton 817.50 , ton $\$ 30$.

\section{Nitrate of Soda}

Should he applied only to crops above ground, and as it is very strong, should not be used carelessly. It acts quickly and hastens maturity of flowers, fruits, and vegetables at least two weeks. Write for price. 

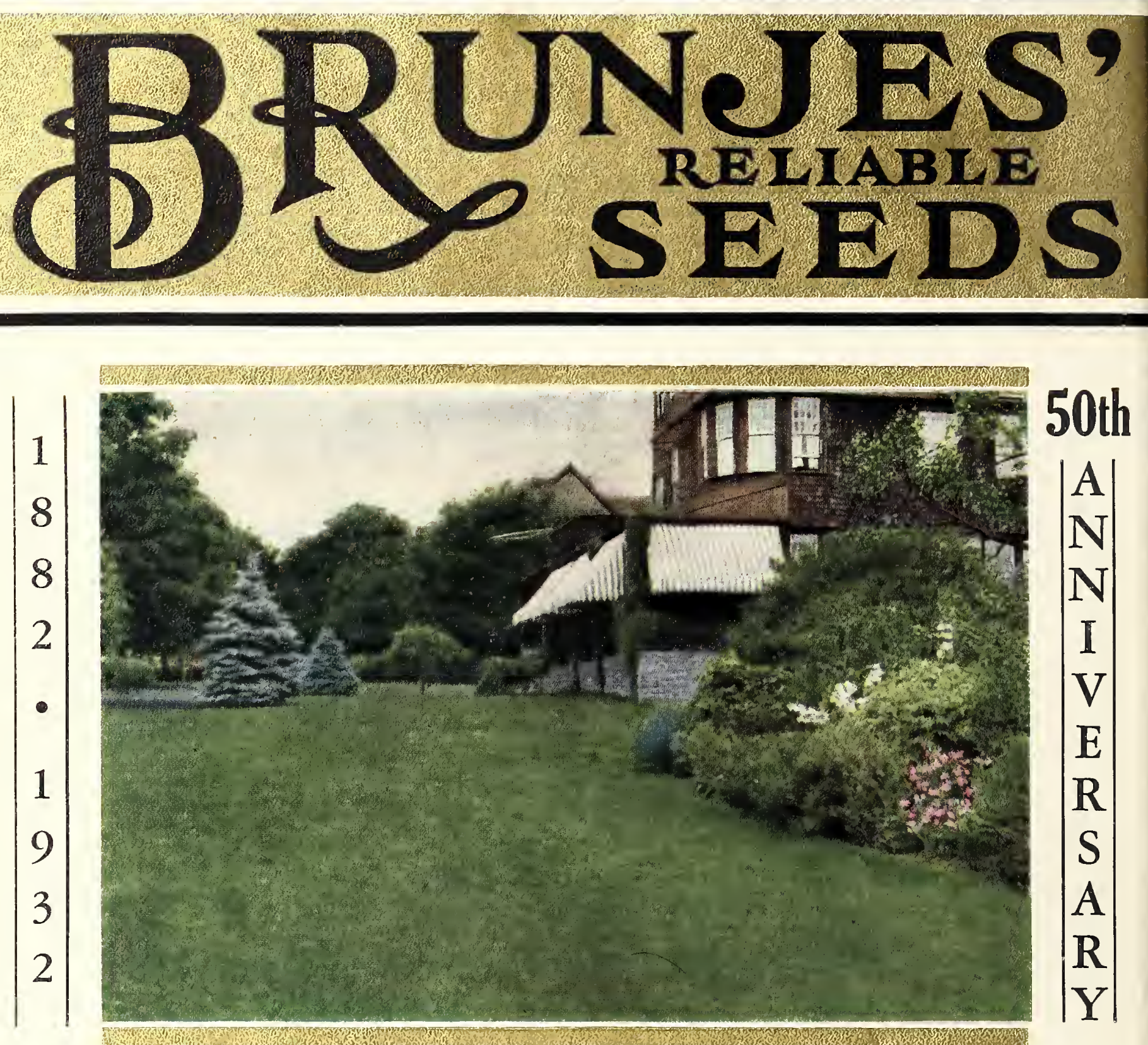

50th

$\left|\begin{array}{c}A \\ \mathrm{~N} \\ \mathrm{~N} \\ \mathrm{I} \\ \mathrm{V} \\ \mathrm{E} \\ \mathrm{R} \\ \mathrm{S} \\ \mathrm{A} \\ \mathrm{R} \\ \mathrm{Y}\end{array}\right|$

\section{H. Brunjes E Sons' Choice Central Park Lawn Grass}

The finest lawns are made from this mixture. Weight, 20 lbs. per bushel. Qt. 30 cts., 2 qts. 55 cts., 4 qts. $\$ 1$, pk. $\$ 1.75$, bus. (20 lbs.) $\$ 6.50$. If wanted by parcel post, add postage at zone rates. One quart weighs $3 / 4 \mathrm{lb}$. Full directions for making a lawn printed on each box.

\section{c⿻一 \\ M. H. BRUNJES \& SONS \\ 1581 Gates Ave., Brooklyn, New York}

